\begin{tabular}{|c|c|}
\hline $\begin{array}{l}\text { 2. To: (Receiving organization) } \\
\text { Distribution }\end{array}$ & $\begin{array}{l}\text { 3. From: (originating organization) } \\
\text { Project Development }\end{array}$ \\
\hline $\begin{array}{l}\text { 5. Proj./Prog./Dept./Div.: } \\
\text { Project } W-211\end{array}$ & $\begin{array}{l}\text { 6. Design Authority/ Design Agent/cog } \\
\text { Engr.: }\end{array}$ \\
\hline
\end{tabular}

8. Originator Renarks:

Flexibie Receiver analysis for the pit platforms to remove equipment from 102-AP and 104-AP.

An independent review of the document was performed by FDNW in accordance with FDNW Procedure Eng. 3.2.

11. Receiver Remarks: 11A. Design Baseline Document? [] Yes "[X] No
4. Rélated EDT No.:

$N / A$

7. Purchase Order No.:

N/A

9. Equip./Component No.:

FTexible Receiver System

10. System/Bldg./Facility:

$$
N / A
$$

12. Major Assm. Dwg. No.:

$$
\text { H-2-79190 }
$$

13. Permit/Permit. Application-No.: $\mathrm{N} / \mathrm{A}$

14. Required Response Date:

$$
10 / 31 / 97
$$

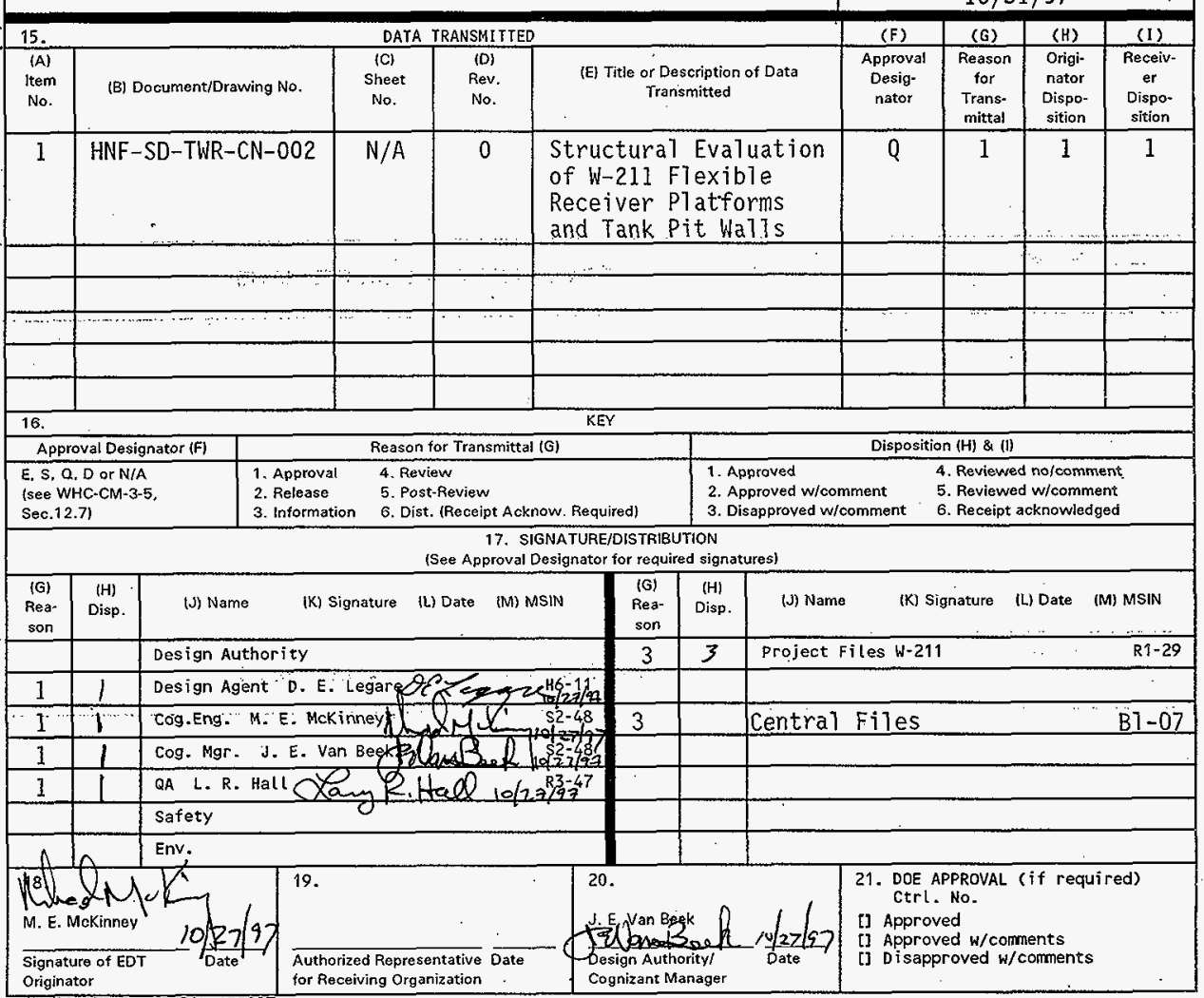




\title{
STRUCTURAL EVALUATION OF W-211 FLEXIBLE RECEIVER PLATFORMS AND TANK PIT WALLS
}

\author{
H. P. Shrivastava, S. K. Kanjilal
}

Fluor Daniel Northwest, Inc, Richland, WA 99352

U.S. Department of Energy Contract DE-AC06-96RL13200

$\begin{array}{llll}\text { EDT/ECN: } & 621743 & \text { UC: } 2000 & \\ \text { Org Code: } & 8 C 471 & \text { Charge Code: } & \text { C07539 } \\ \text { B\&R Code: } & 39 E W 31301 & \text { Total Pages: } 231\end{array}$

Key Words: Flexible Receiver, PTatform Analysis, W-211

Abstract: This document is a structural analysis of the Flexible Receiver Platforms and the tank-pit wall during removal of equipment and during a accidental drop of that equipment. The platform and the pit wal1s must withstand a accidental drop of a mixer and transfer pumps in specific pits in tanks 102-AP and 104-AP. A mixer pump will be removed from riser 11 in pit $2 A$ on tank 241-AP-102. A transfer pump wi11 be removed from riser 13 in pit $2 D$ on tank 241-AP-102 and another transfer pump will be removed from riser $3 A$ in pit $4 A$ on tank 241-AP-104.

IRADEMARK DISCLAIMER. Reference herein to any specific comercial product, process, or service by trade name, trademark, manufacturer, or otherwise, does not necessarily constitute or imply its endorsement, recommendation, or favoring by the United States Government or any agency thereof or its contractors or subcontractors.

Printed in the United States of America. To obtain copies of this document, contact: Document Control Services, P.0. Box 950, Maitstop H6-08, Richland WA 99352, Phone (509) 372-2420;
Fax (509) 376-4989.
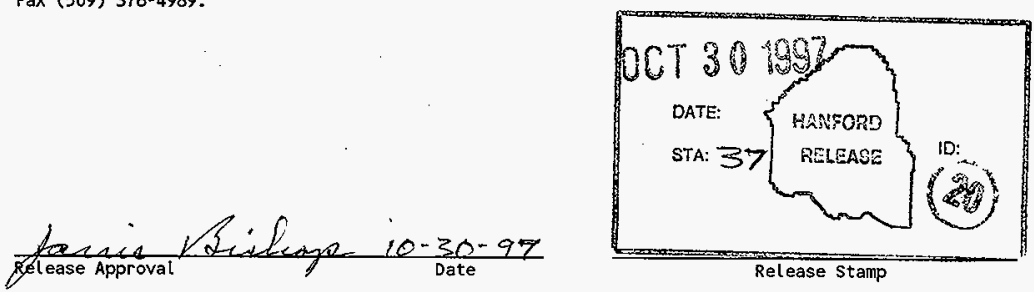


$$
\begin{aligned}
& N \text { Hex } \\
& \text { H\&F-SD-TWR-CN-002 } \\
& \text { Rev. } 0
\end{aligned}
$$

\title{
STRUCTURAL EVALUATION OF W-211 FLEXIBLE RECEIVER PLATFORMS AND TANK PIT WALLS
}

\author{
Prepared by
}

Fluor Daniel Northwest, Inc.

September 1997

for the

\section{Lockheed Martin Hanford Company \\ Richland, Washington}

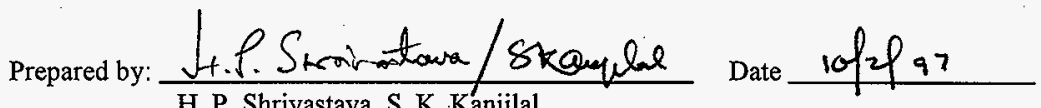
H. P. Shrivastava, S. K. Kanjilal

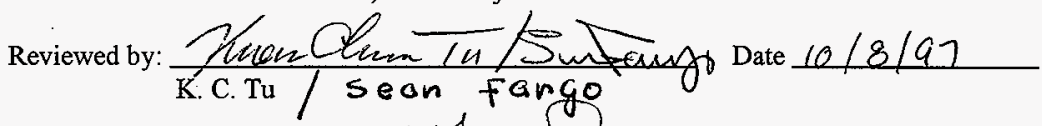
Approved by: Sursam KJan Date 10/13/97 S.K. Farnworth 


\section{CHECKLIST FOR INDEPENDENT REVIEW}

Document Reviewed HNF-SD-TWR-CN-002, Rev. 0

Author H.P. Shrivastava, S.K.Kaniilal

Yes No N/A

$\begin{array}{lll}Y & {[1]} & {[]} \\ {[} & {[]} & {[]} \\ 0 & {[]} & {[]} \\ X & {[]} & {[]} \\ X & {[]} & {[]}\end{array}$

[4 [] []

[if [] []

[. $X[1][]$

[i] [] []

[x] [] []

[i] [] []

ir [] []

b] [1] []

[V [] []
Problem adequately defined.

Necessary assumptions stated and supported.

Computer codes and data files documented

Data used in calculations stated in document.

Data checked for consistency with original source information as applicable.

Mathematical derivations checked including dimensional consistency of results.

Models appropriate and used within range of validity or use outside range of established validity justified.

Hand Calculations checked for errors.

Computer code run streams correct and consistent with analysis documentation

Computer code output consistent with input and with results reported in analysis documentation.

Acceptability limits on analytical results applicable and supported. Limits checked against sources.

Safety margins consistent with good engineering practices.

Conclusions consistent with analytical results and applicable limits. Results and conclusions address all points required in the problem statement.
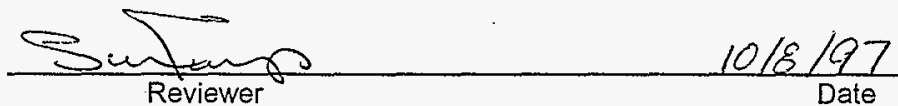

Date 


\section{SUMMARY}

Transient dynamic analyses have been performed to evaluate the ability of the flexible receiver platforms and the tank-pit walls to sustain the loading resulting from mixer pump and transfer pump being dropped from a $60 \mathrm{ft}$ height during their retrieval from the 241-AP-102 and 241-AP-104 underground tanks. The platforms are permitted to deform permanently to the extent that does not result in complete collapse which may damage the tank risers. It is assumed that a $5 \%$ limit on the platform equivalent plastic strain is safe for protecting the tank risers.

The time-varying loads on the tank-pit walls are obtained from the above analyses and the highest loads are used to evaluate the structural adequacy of the pit walls in accordance with the American Concrete Institute code ACI 318R-89. The survival of the concrete walls is the primary concern for these analyses.

The results indicate that the maximum plastic strain for the platform is $4.17 \%$ which results from the mixer pump drop. The impact due to falling transfer pump causes only $0.02 \%$ plastic strain. The loading on the tank pits are also within the safe limits. 


\section{TABLE OF CONTENTS}

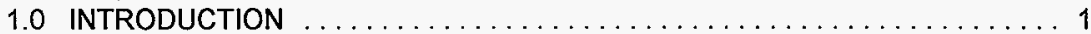

2.0 STRUCTURAL EVALUATION OF PLATFORMS AND PIT WALLS $\ldots \ldots \ldots \ldots 2$

2.1 MIXER PUMP DROP ANALYSIS $\ldots \ldots \ldots \ldots \ldots \ldots \ldots \ldots \ldots \ldots \ldots \ldots \ldots \ldots$

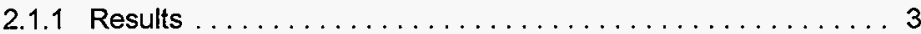

2.2 TRANSFER PUMP DROP ANALYSIS $\ldots \ldots \ldots \ldots \ldots \ldots \ldots \ldots$

2.2.1 Results ......................... 6

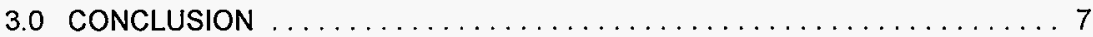

4.0 REFERENCES $\ldots \ldots \ldots \ldots \ldots \ldots \ldots \ldots \ldots \ldots \ldots \ldots \ldots \ldots \ldots \ldots$

\section{APPENDICES}
A Mixer Pump Drop Analysis
B Transfer Pump Drop Analysis
C Structural Evaluation of Pit Walls and Bolted Joints 


\subsection{INTRODUCTION}

Removal of equipment from underground waste storage tanks utilizes a flexible receiver located on top of the riser from which the equipment is to be removed. Recent safety analysis work for Project W-211, Initial Tank Retrieval Systems, has indicated a need for an impact limiting device to be located on top of the flexible receiver platform to mitigate the consequences of the accidental drop of the equipment during removal process. A bellow is also required between the platform and the riser to protect the riser from overloading. Design of the impact limiter and the bellow is beyond the scope of the analyses presented in this document, however, the impact limiter properties need to be considered to predict the loads transmitted to the platform and the tank-pit walls.

The purpose of this document is to evaluate the ability of the platform and the tank-pit walls to withstand the loads resulting from the accidental drop of the mixer and transfer pumps. As directed by the customer, only vertical drop is considered in this analysis. The specific platforms and tank pits addressed herein are those required for removal of the transfer pump and the mixer pump from the 241-AP-102 tank and the transfer pump from the 241-AP-104 tank. In tank 241-AP-102, the mixer pump is to be removed from riser 11 located in pit $2 \mathrm{~A}$ and the transfer pump from riser 13, pit $2 \mathrm{D}$. The transfer pump in tank 241-AP-104 is in riser 3A in pit 4A. The platform used for the removal of the mixer pump from 241-AP-102 will also be used for removing the transfer pump from 241-AP-104. A different platform will be utilized to remove the transfer pump from 241-AP-102 tank.

The weight of the mixer pump assembly is nearly $13,000 \mathrm{lbf}$. The transfer pump approximately weighs $2,000 \mathrm{lbf}$. Both pumps are postulated to drop from a height of 60 $\mathrm{ft}$. Although mixer pump drop is associated with significantly higher impact energy compared to the transfer pump drop, two separate analyses are performed to evaluate each of the platforms. The platform that will be used for the transfer pump removal from the 241-AP-104 is judged acceptable based on the results of the mixer pump drop on this platform and the transfer pump drop on the other platform.

The primary safety concern associated with the accidental drop of these pumps is the structural integrity of the pit walls. The platform is permitted to suffer permanent deformation to the extent that it does not collapse. In view of nearly $20 \%$ ductility of structural steel and that the pump drop is a highly unlikely beyond design basis accident, a $5 \%$ limit on equivalent plastic strain is considered safe.

The tank-pit walls are evaluated for the maximum loads and in accordance with the requirements of the American Concrete Institute code, ACI 318R-89 (ACI 1989). 
The bellows between the riser and the platform will be designed to accommodate vertical displacements of the platform.

\subsection{STRUCTURAL EVALUATION OF PLATFORMS AND PIT WALLS}

An elastic/plastic transient dynamic analysis of each platform is performed to determine the platform responses under the impact loading and the loads on the pit walls. These analyses use version 5.2 of the general purpose finite-element code ANSYS (ANSYS 1994).

The transient dynamic analysis provides time-varying reaction forces at the concrete walls. The maximum reactions are used to evaluate pit-wall structural integrity.

\subsection{MIXER PUMP DROP ANALYSIS}

The mixer pump is located in riser 11 of the 241-AP-102 tank. The flexible receiver platform assembly that will be used to remove the pump is shown on drawing H-2-824709,

Rev. 0 (HNF 1997a). This platform consists of a frame fabricated from W12 440 beams. A 1-in thick cover plate with two nearly square openings is welded to the beams. A flexible receiver adapter plate (HNF 1997c), 2-in thick with a 50 -in diameter hole, is bolted to the cover plate. The platform will be aligned such that this adaptor plate is placed directly above riser 11 . The impact limiter will be installed over this plate prior to the pump removal. A 1 -in thick solid plate will be bolted to the platform to cover the opening that is not in use while the mixer pump is removed.

The beams and the plates are modeled using SHELL43 element which is a plastic shell element appropriate for an elastic/plastic analysis. The CONTAC52 elements that permit the beam to lift up vertically are generated, at appropriate beam nodes, between the beams and pit walls. The CONTAC52 elements are also used between the adapter plate and the cover plate at those nodes of these plates where they are not bolted together. The adapter plate node and the cover plate node at a bolt location are coupled together in all three translational directions.

The pump mass is modeled using a spring and gap element (COMBIN40) 
connected to the center of a rigid plate which, in turn, is connected to the adapter plate by a set of COMBIN40 elements that are allowed to deform at a constant load. These COMBIN40 elements represent the impact limiter that deforms at a constant load after an initially small linear deformation.

The impact limiter has an inside diameter of 50 -in, outside diameter of 70 -in and a crush strength of $170 \mathrm{lbf} / \mathrm{in}^{2}$. This provides a crush load of $320,000 \mathrm{lbf}$. There are a total of 32 springs representing the impact limiter. Therefore, the analysis model assumes that each spring deforms at a constant load of 10,000 lbf: The initial stiffness has been arbitrarily assumed as $50,000 \mathrm{lbf} / \mathrm{in}^{2}$.

As the structure is symmetric with respect to the east-west axis, only half model of the platform is used in this analysis. The finite-element model is shown in Figures 1 to 3 .

The transient analysis is performed in three load sets. The first load set is a static load case in which the pump mass is held at a height of 720 in. In the second load set, the mass is released and dynamic analysis is performed starting from zero time to $1.93 \mathrm{sec}$ during which the pump falls freely and makes initial contact with the impact limiter. In this load set, automatic time stepping option is used with 1000 maximum load steps permitted. As the platform is expected to deform inelastically, the automatic time stepping is turned off in the third load set. However, during the next $0: 06 \mathrm{sec}$, a very small fixed time step of $0.0001 \mathrm{sec}$ is used to accurately predict the inelastic response.

The analysis input and output files are included in Appendix $A$. The results are post-processed using /POST26 module of the ANSYS program to obtain the timehistory plots of the reaction forces, bolt forces, and displacements.

\subsubsection{Results}

The time-history plots of reaction forces, bolt loading, and displacements at critical nodes are shown in Figures 4 through 16. Their extreme values are listed on pages 77 and 78 of Appendix A. Some of the significant results are given below:

- Reaction forces at the pit West wall: The sum of the maximum reactions at nodes 10560 to 10569 is $143,540 \mathrm{lbf}$. This force acts over a $5 \mathrm{ft}$ length of the wall. Therefore, the average loading on this wall is $28,700 \mathrm{lbf} / \mathrm{ft}$.

?ANSYS is a trademarked proprietary code, but a user's license is commercially available from Swanson Analysis Systems., Inc. 
- Reaction force at the North and South walls: The maximum reaction force occurs at node 10440 and is equal to $71,900 \mathrm{lbf}$.

- The maximum vertical displacement of the impacted beam is 3.4 in. The bellow assembly must be capable to accommodate this displacement.

- The maximum horizontal displacement of the beam ends is less than $1 / 2$ in. The alignment bolts must be turned back $1 / 2$ in to avoid undesirable punching load on the walls.

- Bolt Loading: The axial and shear loads on bolts used for connecting the flexible receiver to the cover plate are given below:

Table 1: Bolt Loads, 241-AP-102, Pit 2A Platform

\begin{tabular}{||c|c|c|c|c||}
\hline Node No. & $\begin{array}{c}\text { Axial Load } \\
\text { (lbf) }\end{array}$ & $\begin{array}{c}\text { Shear, FX } \\
\text { (lbf) }\end{array}$ & $\begin{array}{c}\text { Shear, FY } \\
\text { (lbf) }\end{array}$ & $\begin{array}{c}\text { Total Shear } \\
\text { (lbf) }\end{array}$ \\
\hline \hline 457 & 5,268 & 3,014 & 10,360 & 10,790 \\
\hline 474 & 6,937 & 10,620 & 9,699 & 14,382 \\
\hline 494 & 7,764 & 10,260 & 5,422 & 11,605 \\
\hline 514 & 11,330 & 19,380 & 5,315 & 20,096 \\
\hline 534 & 7,215 & 31,220 & 19,580 & 36,852 \\
\hline 577 & 6,879 & 518 & 4,104 & 4,137 \\
\hline
\end{tabular}

The impact limiter vertical displacement is $27.12 \mathrm{in}$. which is less than the design stopping distance of 29.8 in.

- The maximum equivalent plastic strain, as shown in Figures 17 to 19 , is $4.17 \%$.

The bolted connections and the pit walls are evaluated in Appendix C. 1-in nominal diameter $\mathrm{A} 490$ bolts are adequate to sustain the impact load. The only exceptions are the bolt at node 534 and the bolt located directly opposite to this node. These bolts have high shear loads. One additional bolt is added in close proximity of this node and one on the opposite side to reduce the shear loading on these two bolts. 


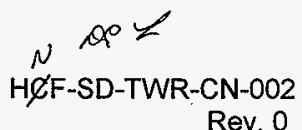

The pit walls are shown to have adequate safety margin when subjected to the impact load resulting from the mixer pump accidental drop. The peak reaction forces are compared with the allowable concentrated load on tank dome and the tank dome is found safe to carry the impact loads.

The $\mathrm{W} 12 \times 40$ beams, directly under the applied loading deform inelastically. However, the maximum plastic strain, localized in a small area, is less than $5 \%$ and, therefore, the beams are not expected to collapse. Two stiffeners are provided at each location of the center beam where it rests on the pit wall to prevent flange bending and web crippling.

\subsection{TRANSFER PUMP DROP ANALYSIS}

The transfer pumps are located in riser 13 of the 241-AP-102 tank and riser $3 \mathrm{~A}$ of the 241-AP-104 tank. The flexible receiver platform assembly, analyzed above, will also be used to remove the transfer pump from the 241-AP-104 tank. The mixer pump drop is more critical for this platform and the tank pit. Therefore, the second platform, shown on drawing H-2-824707, Rev. O (HNF 1997b) is analyzed for loading resulting from the accidental drop of the transfer pump.

This platform also consists of a frame fabricated from $\mathrm{W} 12 \times 40$ beams and a 1 in thick cover plate. The flexible receiver adapter plate is also identical to that used for the previous platform except that its thickness is only $1 \frac{1}{2}$ in.

The finite-element model of this platform uses the same types of elements as those described in Section 2.1. The analysis methodology is also identical. However, as there is no symmetry plane with respect to the platform geometry and the applied loading, a full model is used to analyze this platform. The model is shown in Figures 20 through 22.

The pump mass is also modeled using a spring and gap element (COMBIN40) connected to the center of a rigid plate which, in turn, is connected to the adapter plate by a set of COMBIN40 elements that are allowed to deform at a constant load. The weight of this pump, considered in this analysis is $2,000 \mathrm{lbf}$ although the actual weight is slightly less.

The impact limiter crushes at $75,000 \mathrm{lbf}$ loading. There are a total of 32 springs representing the impact limiter and, therefore, each spring element is modeled to 


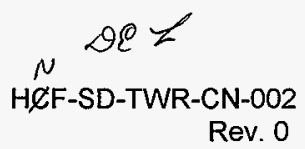

deform at a constant load of $2,350 \mathrm{lbf}$. The initial stiffness has been arbitrarily assumed as $50,000 \mathrm{lbf} / \mathrm{in}^{2}$.

The transient analysis is again performed in three load sets. The first load set is a static load case in which the pump mass is held at a height of 720 in. In the second load set, the mass is released and dynamic analysis is performed starting from zero time to $1.93 \mathrm{sec}$ during which the pump falls freely and makes initial contact with the impact limiter. In this load set, automatic time stepping option is used with 1000 maximum load steps permitted. As the platform is expected to deform inelastically, the automatic time stepping is turned off in the third load set. However, during the next $0.05 \mathrm{sec}$, a very small fixed time step of $0.0001 \mathrm{sec}$ is used to accurately predict the inelastic response.

The analysis input and output files are included in Appendix B. The results are post-processed using /POST26 module of the ANSYS program to obtain the timehistory plots of the reaction forces, bolt forces, and displacements.

\subsubsection{Results}

The time-history plots of reaction forces, bolt loading, and displacements at critical nodes are shown in Figures 23 through 41. Their extreme values are listed on pages 68 and 69 of Appendix B. Some of the significant results are given below:

- Reaction forces at the pit South wall: The sum of the maximum reactions at nodes 11315 to 11329 is $139,560 \mathrm{lbf}$ (see page B-68). This force acts over nearly $8 \mathrm{ft}$ length of the wall. Therefore, the average loading on this wall is $17,500 \mathrm{lbf} / \mathrm{ft}$.

- Reaction forces at the pit North wall: The maximum reaction occurs at node 11628 and is equal to $47,650 \mathrm{lbf}$.

- $\quad$ Reaction force at the East and West walls: The maximum reaction force occurs at node 11465 and is equal to $34,130 \mathrm{lbf}$.

- The maximum vertical displacement of the impacted beam, as shown in Figure 41 , is less than 0.25 in. The bellow assembly should have no problem accommodating this displacement.

- Bolt Loading: The axial and shear loads on bolts used for connecting the flexible 


\section{Rev. 0}

receiver to the cover plate are given in Table 2 below:

- The impact limiter vertical displacement is 17.83 in. which is less than the design stopping distance of 24 in.

- The maximum equivalent plastic strain, as shown in Figure 38 , is $0.02 \%$. Thus, the platform structure remains nearly elastic.

Table 2: Bolt Loads, 241-AP-102, Pit 2D Platform

\begin{tabular}{||c|c|c|c|c||}
\hline Node No. & $\begin{array}{c}\text { Axial Load } \\
(\mathrm{lbf})\end{array}$ & $\begin{array}{c}\text { Shear, FX } \\
(\mathrm{lbf})\end{array}$ & $\begin{array}{c}\text { Shear, FY } \\
(\text { (lbf) }\end{array}$ & $\begin{array}{c}\text { Total Shear } \\
(\mathrm{lbf})\end{array}$ \\
\hline \hline 372 & 5,058 & 9,666 & 6,796 & 11,816 \\
\hline 432 & 6,744 & 28,280 & 3,524 & 28,499 \\
\hline 456 & 6,172 & 10,710 & 14,510 & 18,035 \\
\hline 460 & 5,718 & 21,720 & 14,340 & 26,027 \\
\hline 364 & 5,230 & 9,281 & 10,730 & 14,187 \\
\hline 424 & 5,106 & 12,750 & 6,732 & 14,418 \\
\hline 336 & 6,471 & 2,851 & 6,309 & 6,923 \\
\hline 340 & 5,556 & 4,175 & 5,276 & 6,728 \\
\hline
\end{tabular}

The bolted connections and the pit walls are evaluated in Appendix C. 1-in nominal diameter $A 490$ bolts are adequate to sustain the impact load. The only exceptions are the bolts at nodes 432 and 460 that have high shear loads. One additional bolt is added in close proximity of these nodes to reduce the shear loading on these two bolts. The pit walls are shown to have adequate safety margin when subjected to the impact load resulting from the transfer pump accidental drop.

The $\mathrm{W} 12 \times 40$ beams, remain nearly elastic. The maximum plastic strain, localized in a very small area, is less than $0.0025 \%$. The beams will not, therefore, collapse. 


$$
\begin{aligned}
& N \infty \odot Z \\
& \text { HCF-SD-TWR-CN-002 }
\end{aligned}
$$

Rev. 0

\subsection{CONCLUSION}

The two platforms designed for removal of the mixer and transfer pumps are structurally adequate to sustain the impacts loads caused by the postulated pump drops. The mixer pump drop is associated with a high impact energy. The platform deforms inelastically, however, the maximum plastic strain suffered by the $\mathrm{W} 12 \times 40$ beams is less than $5 \%$. In case of the transfer pump, the structure remains virtually elastic.

The pit walls have been evaluated using the maximum reaction force and have been found to be safe under the impact loads. Minor changes in the adaptor plate design and associated bolted connections, as a result of these analyses, have already been incorporated in the final design.

\subsection{REFERENCES}

ANSYS, 1994, User's Manual, Version 5.2, ANSYS Inc., Houston, Pennsylvania. ACI, 1989, Building Code Requirements for Reinforced Concrete, ACI 318R-89, American Concrete Institute, Detroit, Michigan.

HNF, 1997a, LLCE Platform Assembly 16' x 10' Piece, Dwg. No. H-2-824709, Rev. 0 , U.S. Department of Energy, Richland, Washington.

HNF, 1997b, LLCE Platform Assembly 13'x 8'/1 Piece, Dwg. No. H-2-824707, Rev. 0 ,

U.S. Department of Energy, Richland, Washington.

HNF, 1997c, LLCE Flexible Receiver Adapter 50" Plate, Dwg. No. H-2-82471.8, Rev. 1 ,

U.S. Department of Energy, Richland, Washington. 


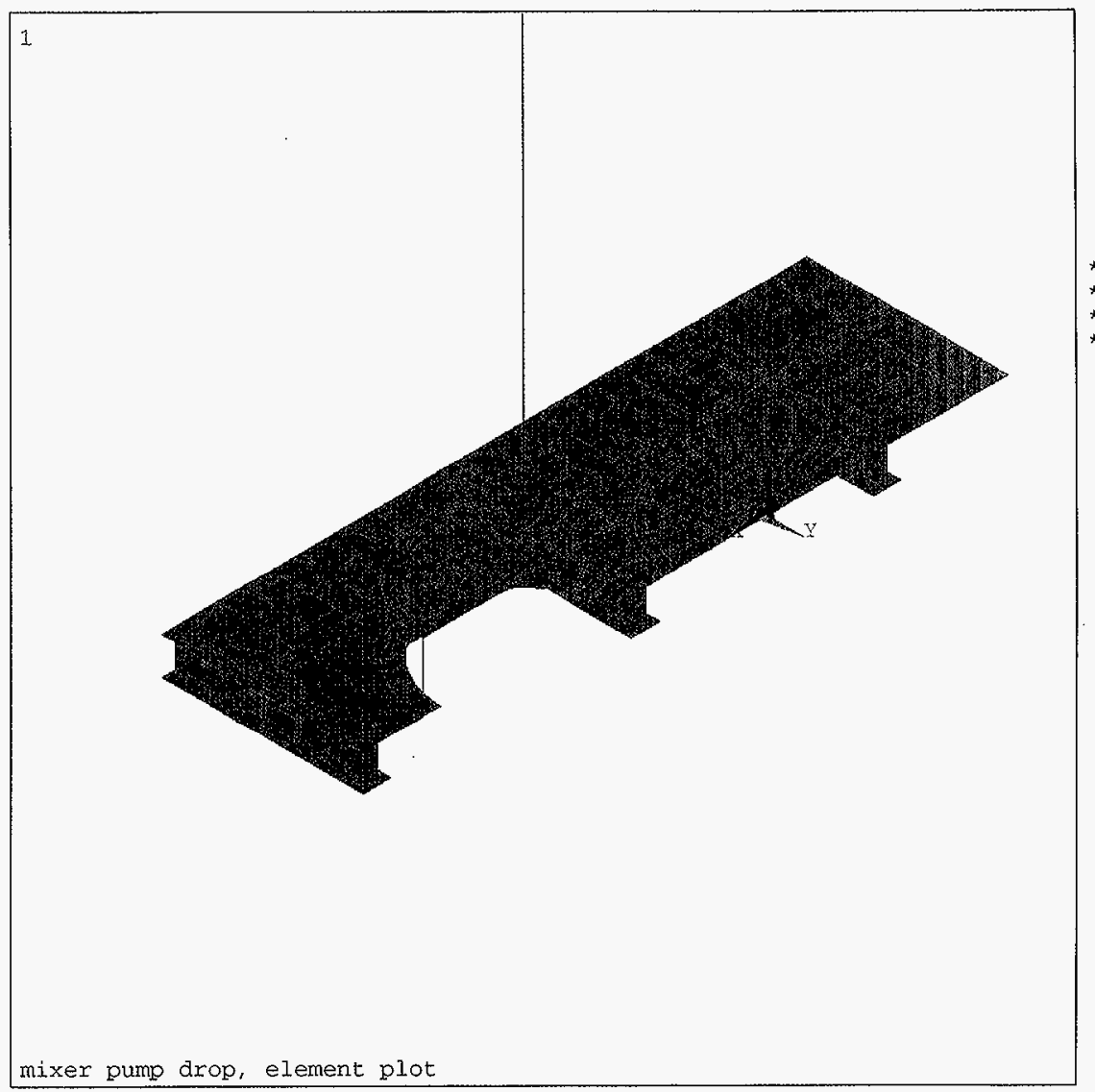

ANSYS 5.2

AUG 261997

$08: 25: 13$

PLOT NO. 1

ELEMENTS

TYPE NUM

$\mathrm{XV}=1$

$Y V=1$

$\mathrm{ZV}=1$

$*$ DTST $=111.622$

$\star \mathrm{XF}=160.402$

$\star Y F \quad=94.229$

$\star \mathrm{ZF}=118.797$

VUP $=\mathrm{Z}$

Z-BUFFER

Figure 1 


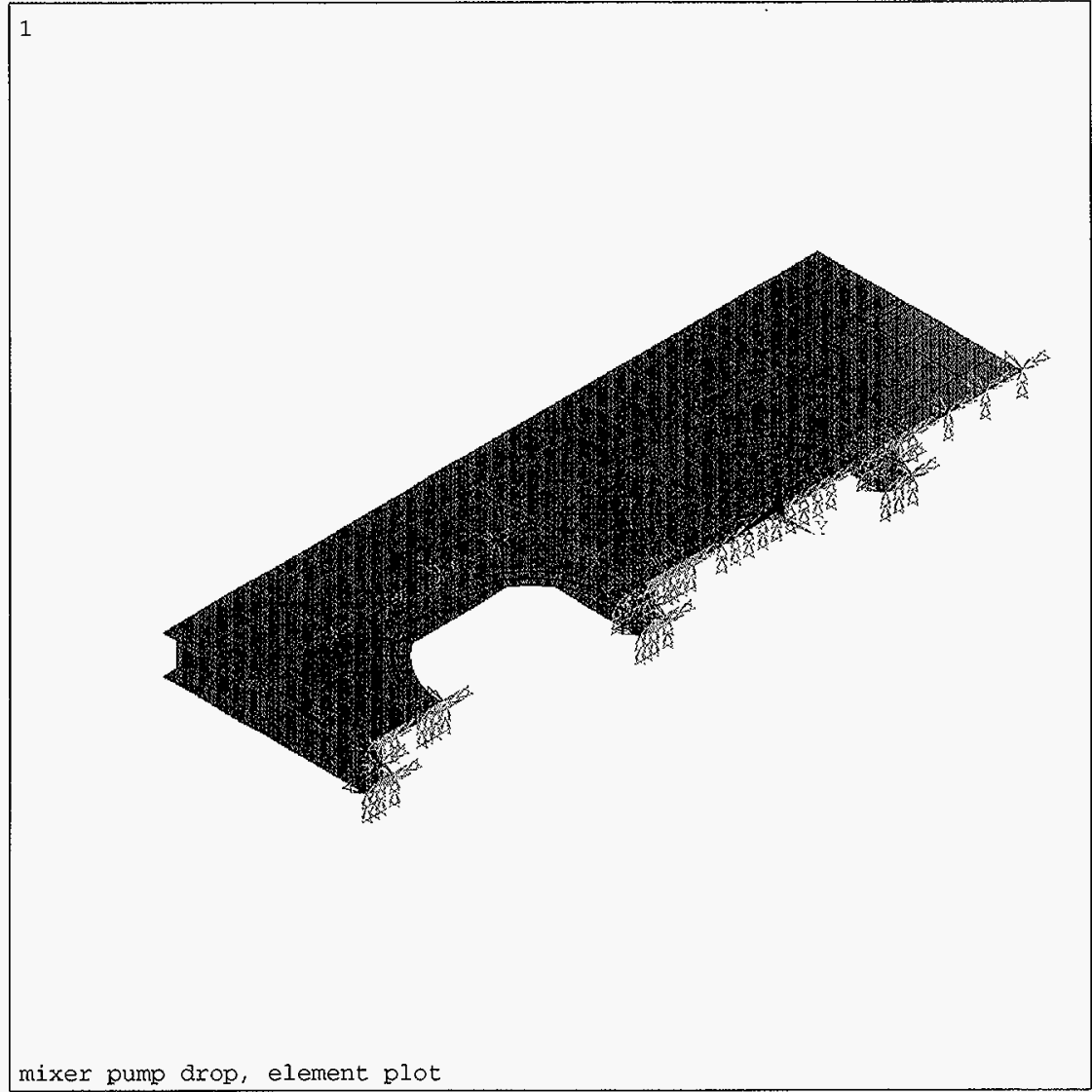

ANSYS 5.2

AUG $26 \quad 1997$

$08: 27: 06$

PLOT NO.

ELEMENTS

TYPE NUM

U

Het

ACEI

$\mathrm{XV}=1$

$\mathrm{YV}=1$

$\mathrm{ZV}=1$

$\star$ DIST $=111.622$

$\star \mathrm{XF}=160.402$

$\star \mathrm{YF}=94.229$

${ }^{*} \mathrm{ZF}=118.797$

VUP $=\mathrm{Z}$

Z-BUFFER

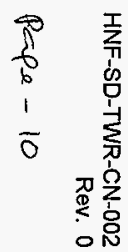

Figure 2 


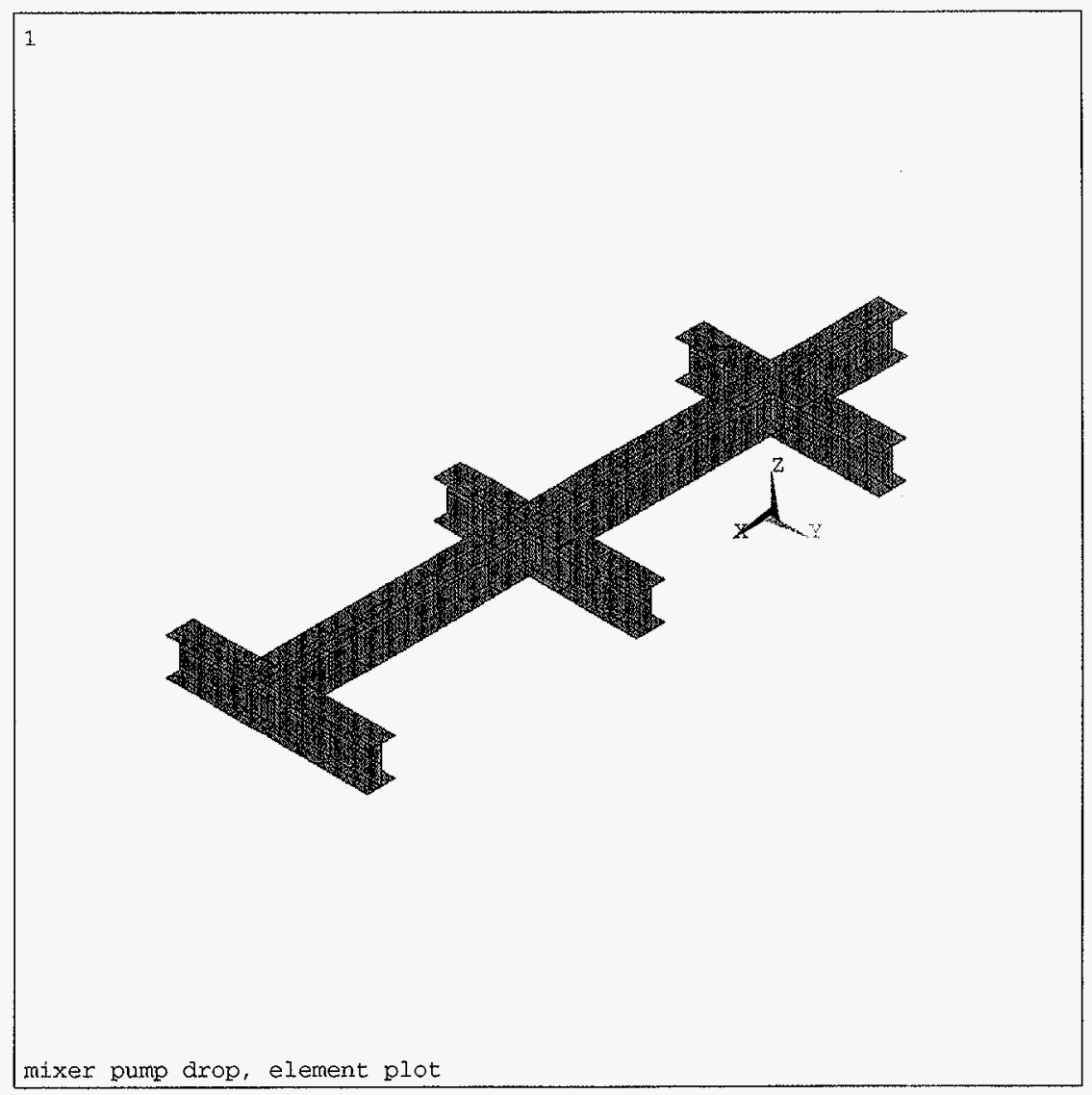

ANSYS 5.2

AUG $26 \quad 1997$

$08: 28: 08$

PLOT NO. 3

ELEMENTS

TYPE NUM

$X V=1$

$Y V=1$

$\mathrm{ZV}=1$

$* \mathrm{DIST}=111.622$

$* X F \quad=160,402$

*YF $=94.229$

${ }^{*} \mathrm{ZF} \quad=118.797$

VUP $=\mathrm{Z}$

Z-BUFFER

Figure 3

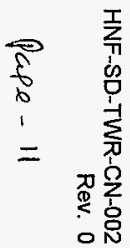


HNF-SD-TWR-CN-002

Rev. 0

Pcye-12

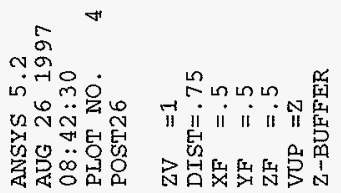

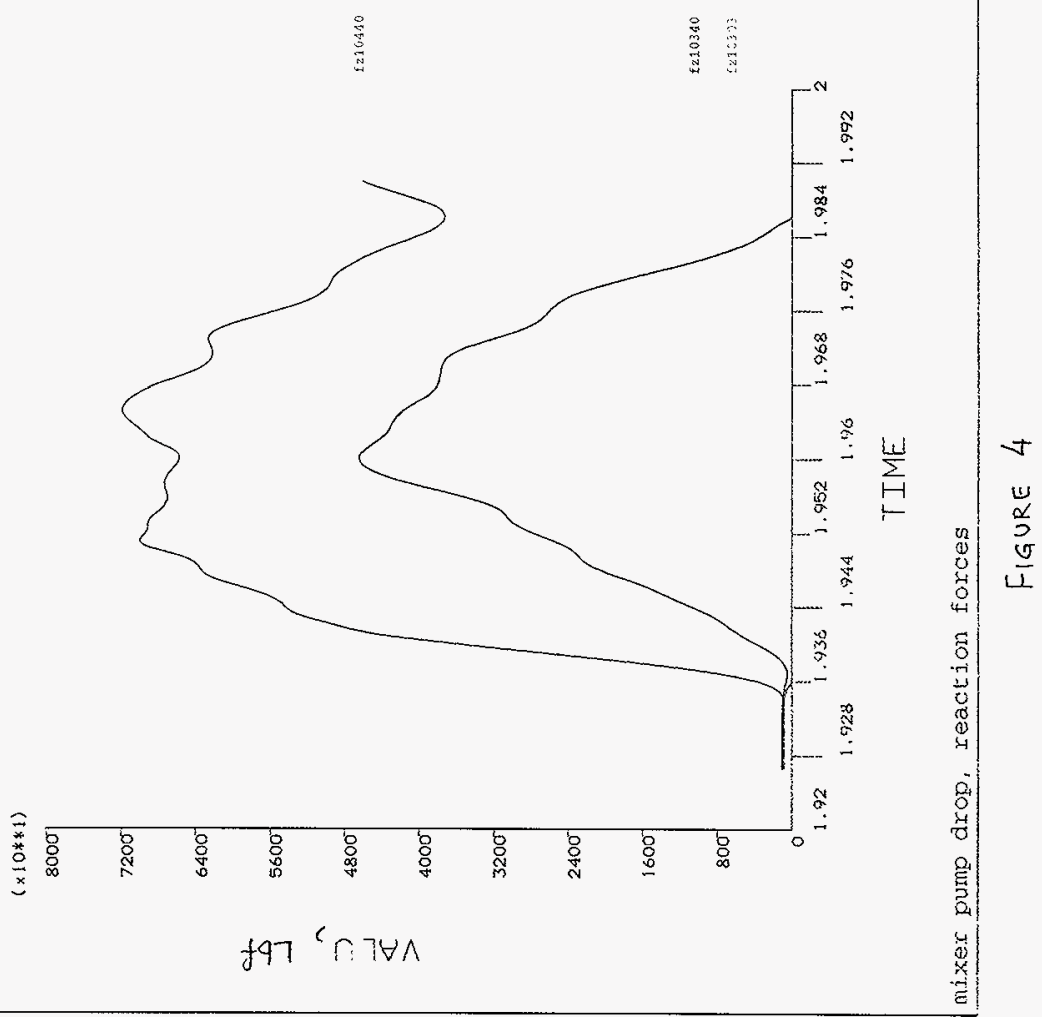




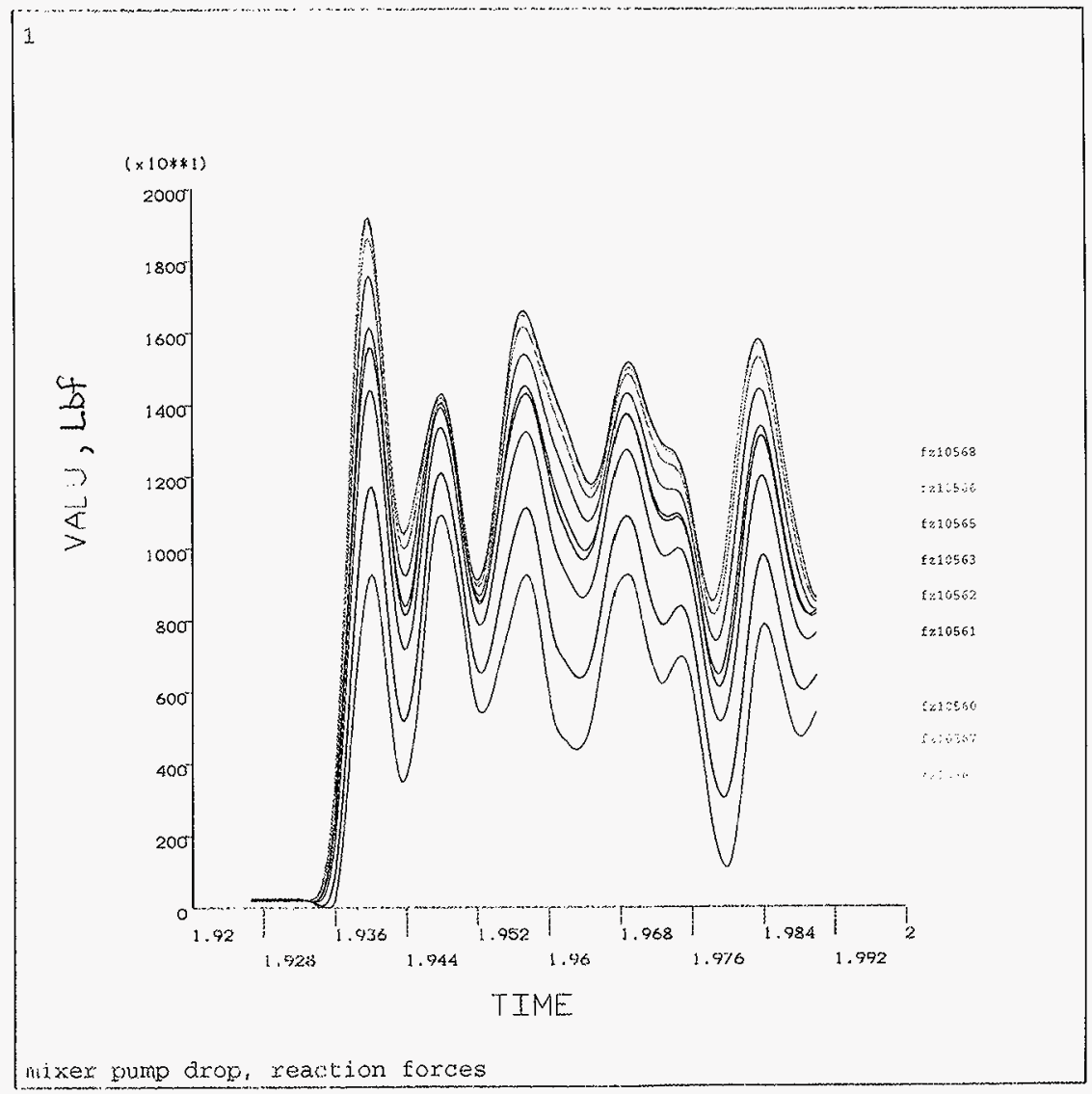

ANSYS 5.2

AUG 261997

$08: 43: 34$

PLOT NO.

5

POST26

$z V=1$

DIST $=.75$

$\mathrm{XF}=.5$

$Y F=.5$

$\mathrm{ZF}=.5$

$V U P=Z$

$Z$-BUEFER

FIGURE 5

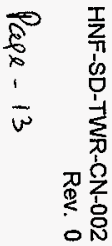




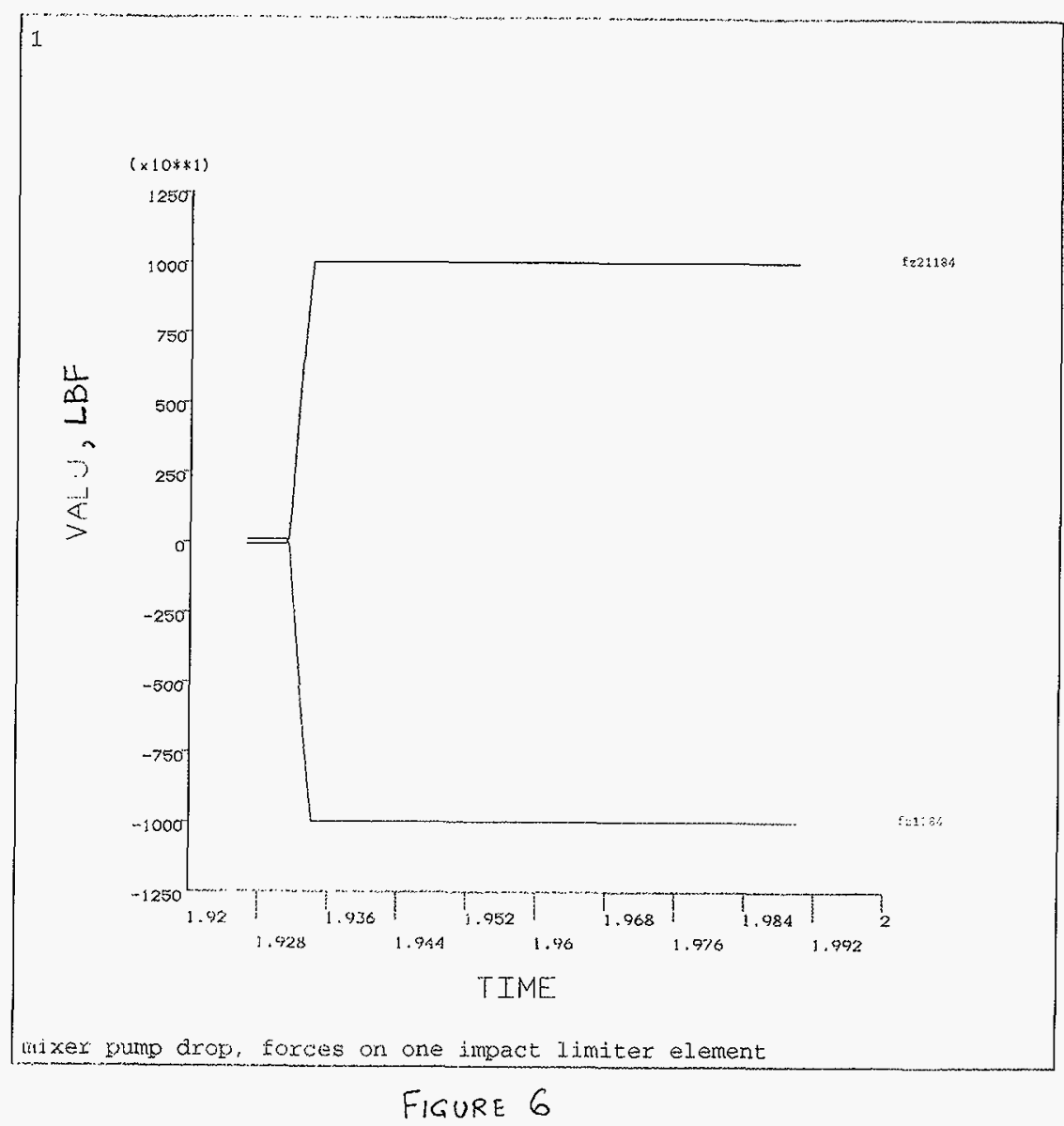

ANSYS 5.2

AUG $26 \quad 1997$

$08: 46: 34$

PLOT NO.

POST26

$\mathrm{zV}=1$

DIST $=.75$

$\mathrm{XF}=.5$

$\mathrm{YF}=.5$

$Z F=.5$

VUP $=Z$

Z-BUFFER 
HNF-SD-TWR-CN-002

Rev. 0

Pape-15
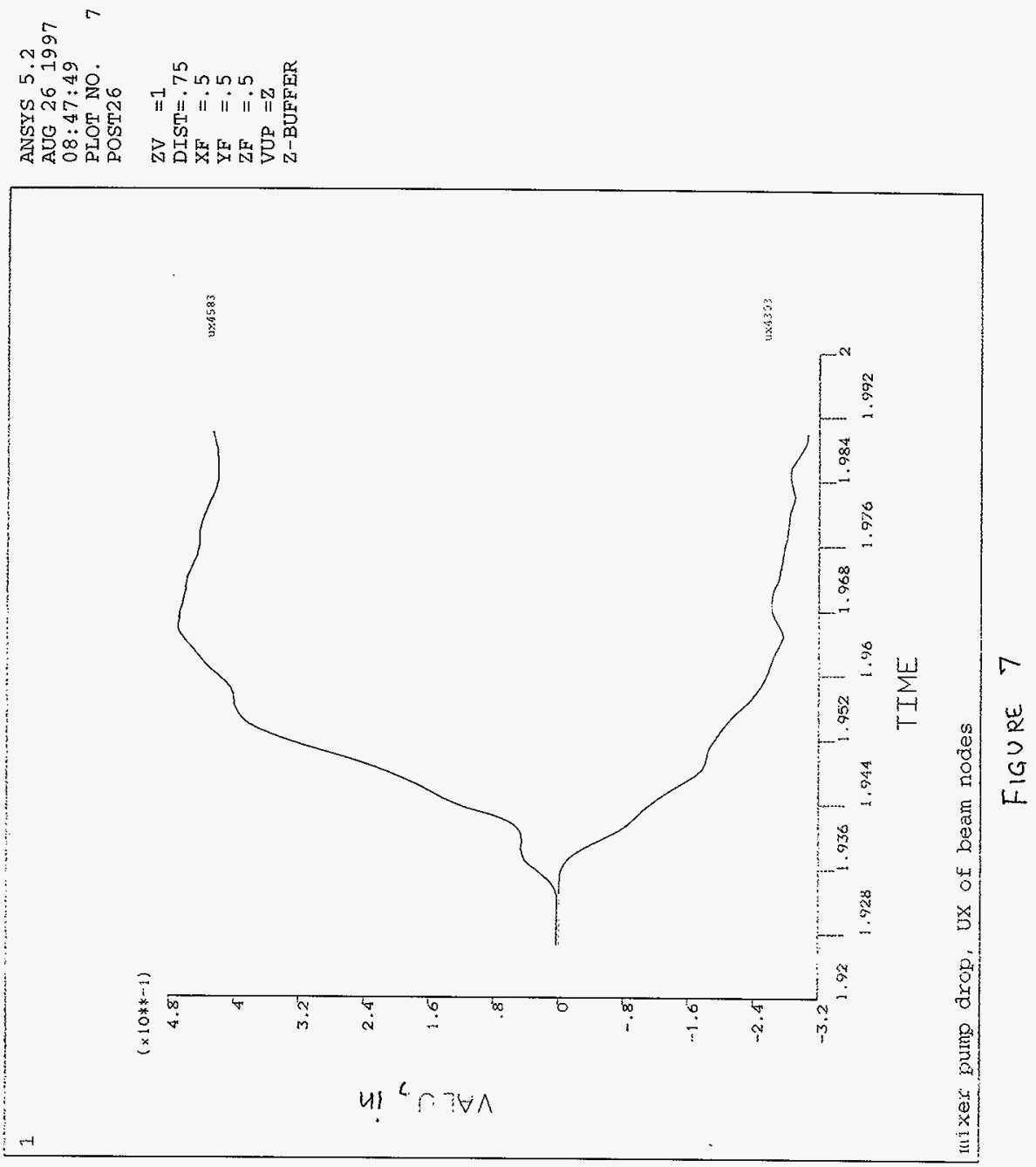


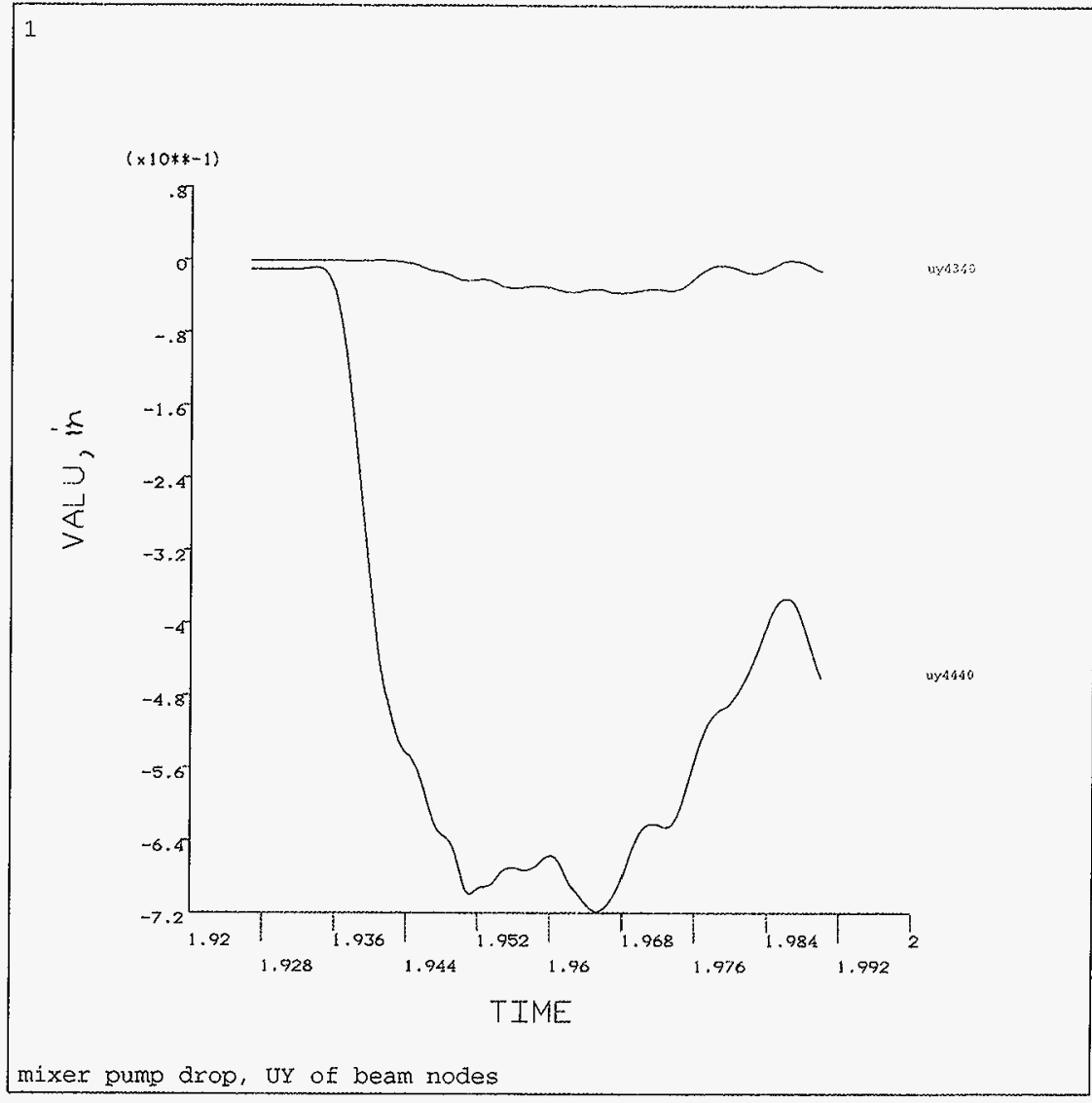

ANSYS 5.2

AUG $26 \quad 1997$

$08: 48: 48$

PLOT NO. 8

POST2 6

$\mathrm{ZV}=1$

DIST $=.75$

$\mathrm{XF}=.5$

$\mathrm{YF}=.5$

$\mathrm{ZF}=.5$

$\mathrm{VUP}=\mathrm{Z}$

$Z$-BUFFER

FIGURE 8 

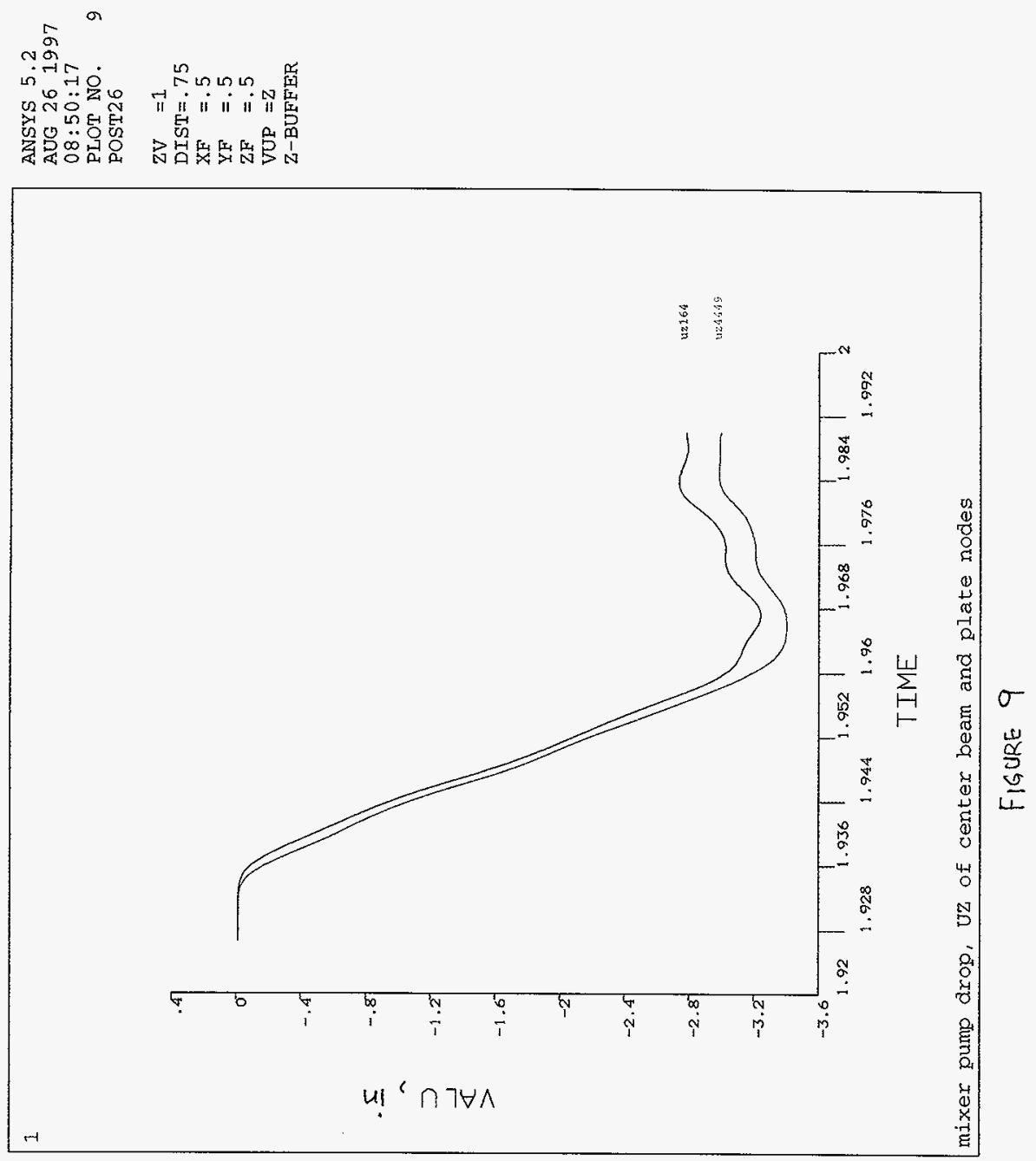


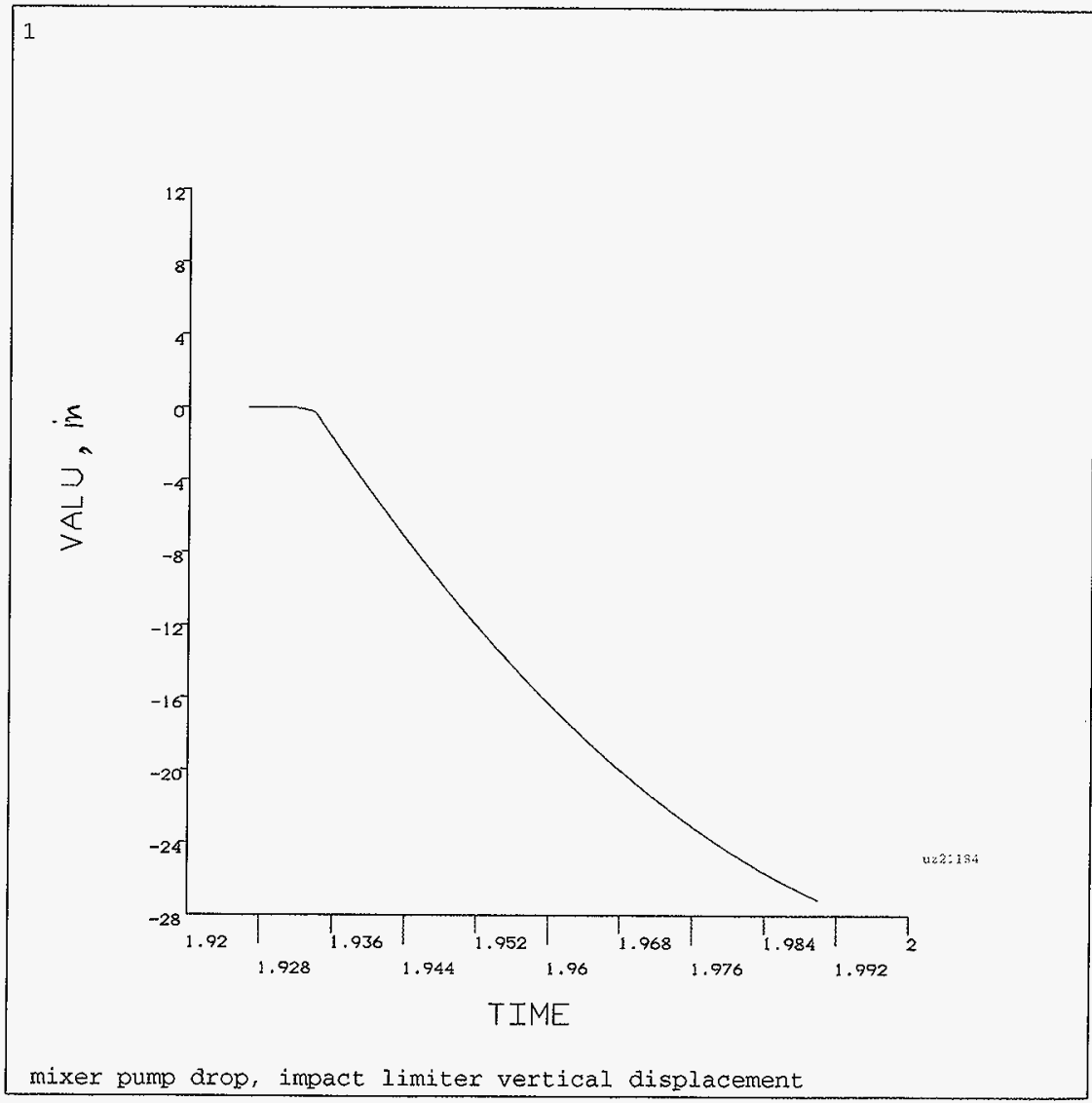

ANSYS 5.2

AUG 261997

$08: 54: 44$

PLOT NO. 10

POST2 6

$\mathrm{ZV}=1$

DIST $=.75$

$\mathrm{XF}=.5$

$\mathrm{YF}=.5$

$\mathrm{ZF}=.5$

VUP $=Z$

Z-BUFFER

FIGURE 10 


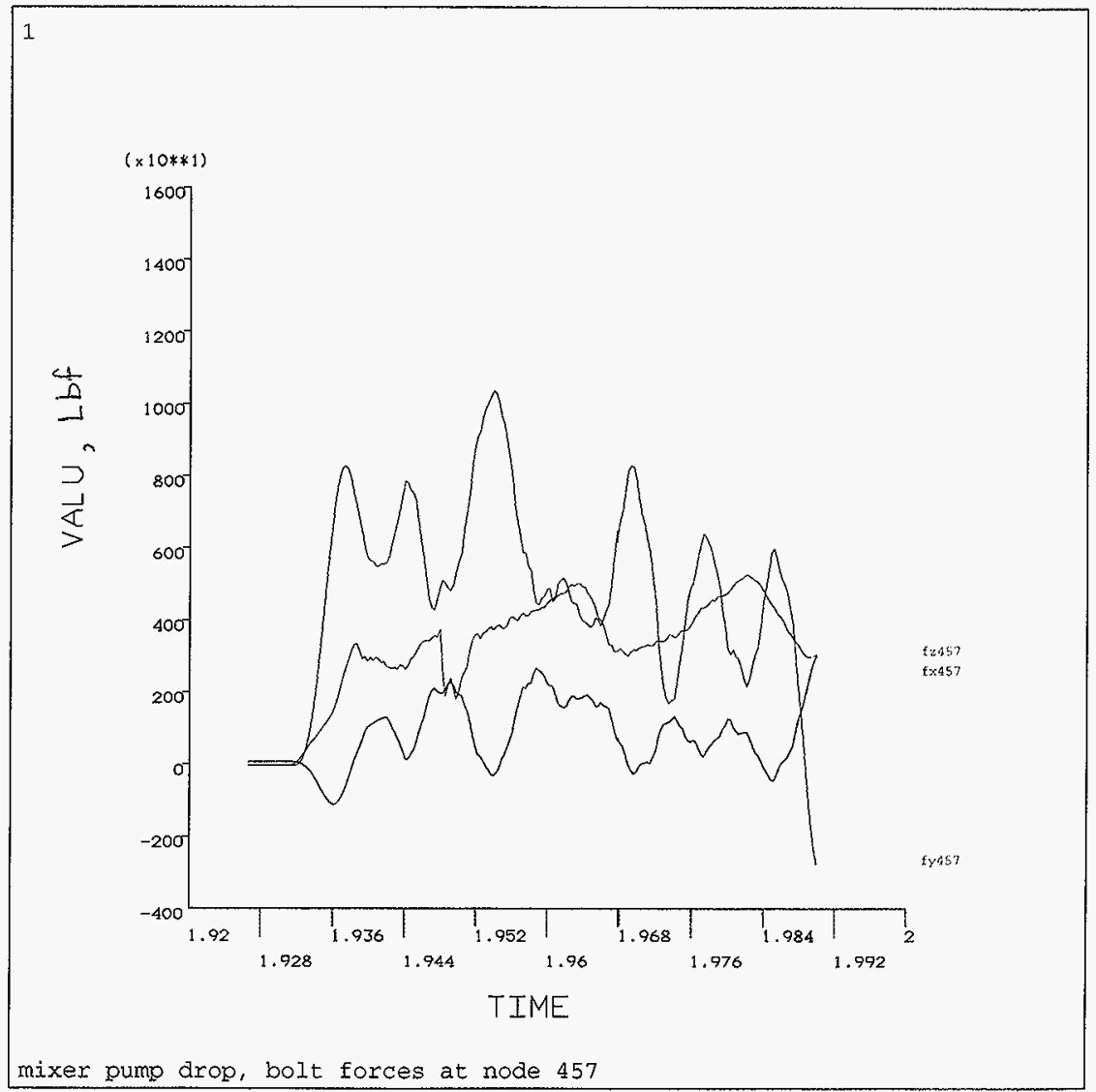

ANSYS 5.2

AUG $26 \quad 1997$

$09: 21: 01$

PLOT NO. 11

POST26

$\mathrm{ZV}=1$

$\mathrm{DIST}=.75$

$\mathrm{XF}=.5$

$\mathrm{YF}=.5$

$\mathrm{ZF}=.5$

$V U P=Z$

$\mathrm{Z}$-BUFFER 


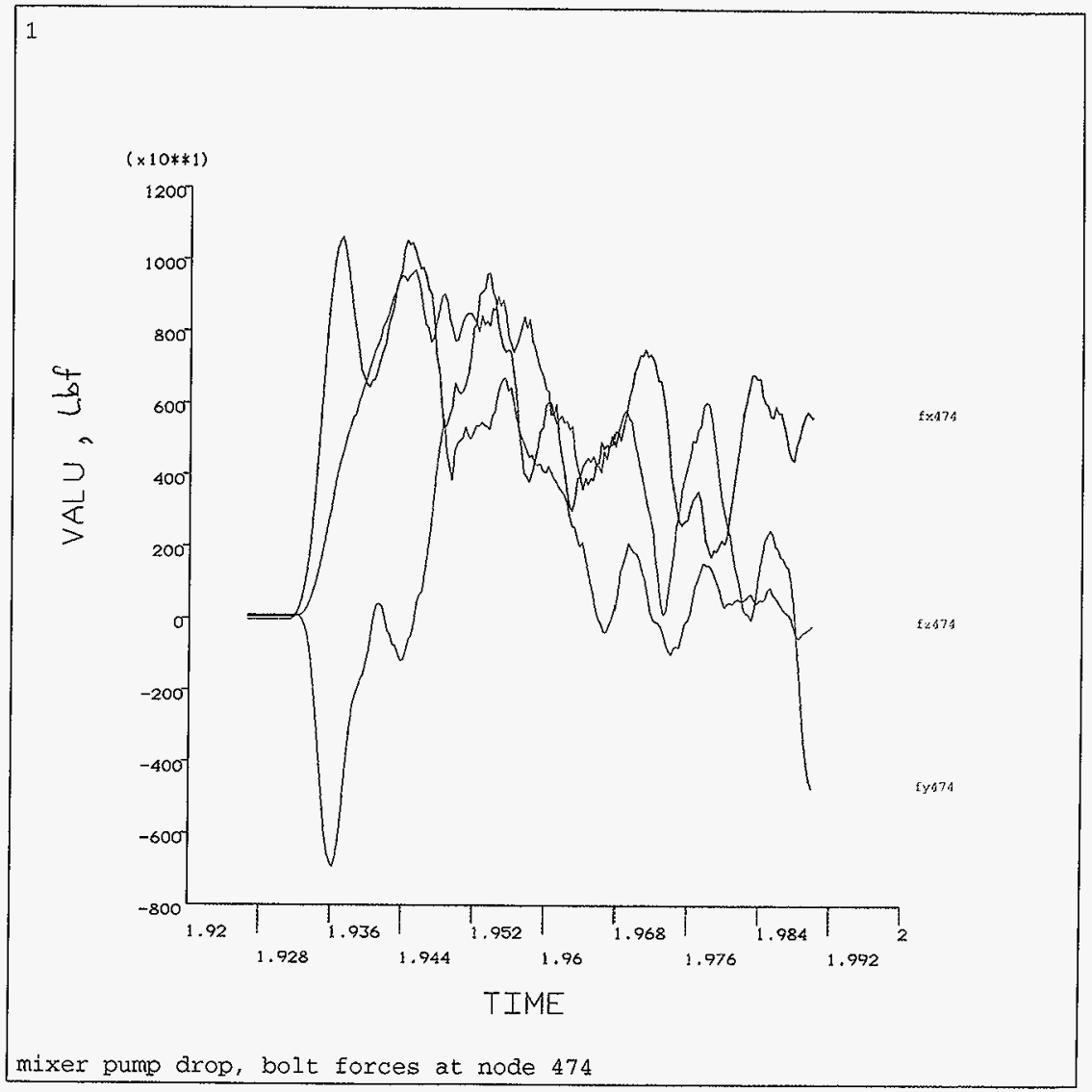

ANSYS 5.2

AUG 261997

$09: 22: 13$

PLOT NO. 12

POST26

$\mathrm{ZV}=1$

$\mathrm{DIST}=.75$

$\mathrm{XF}=.5$

$Y F=.5$

$\mathrm{ZF}=.5$

$\mathrm{VUP}=\mathrm{Z}$

$Z$-BUFFER

Figure 12 


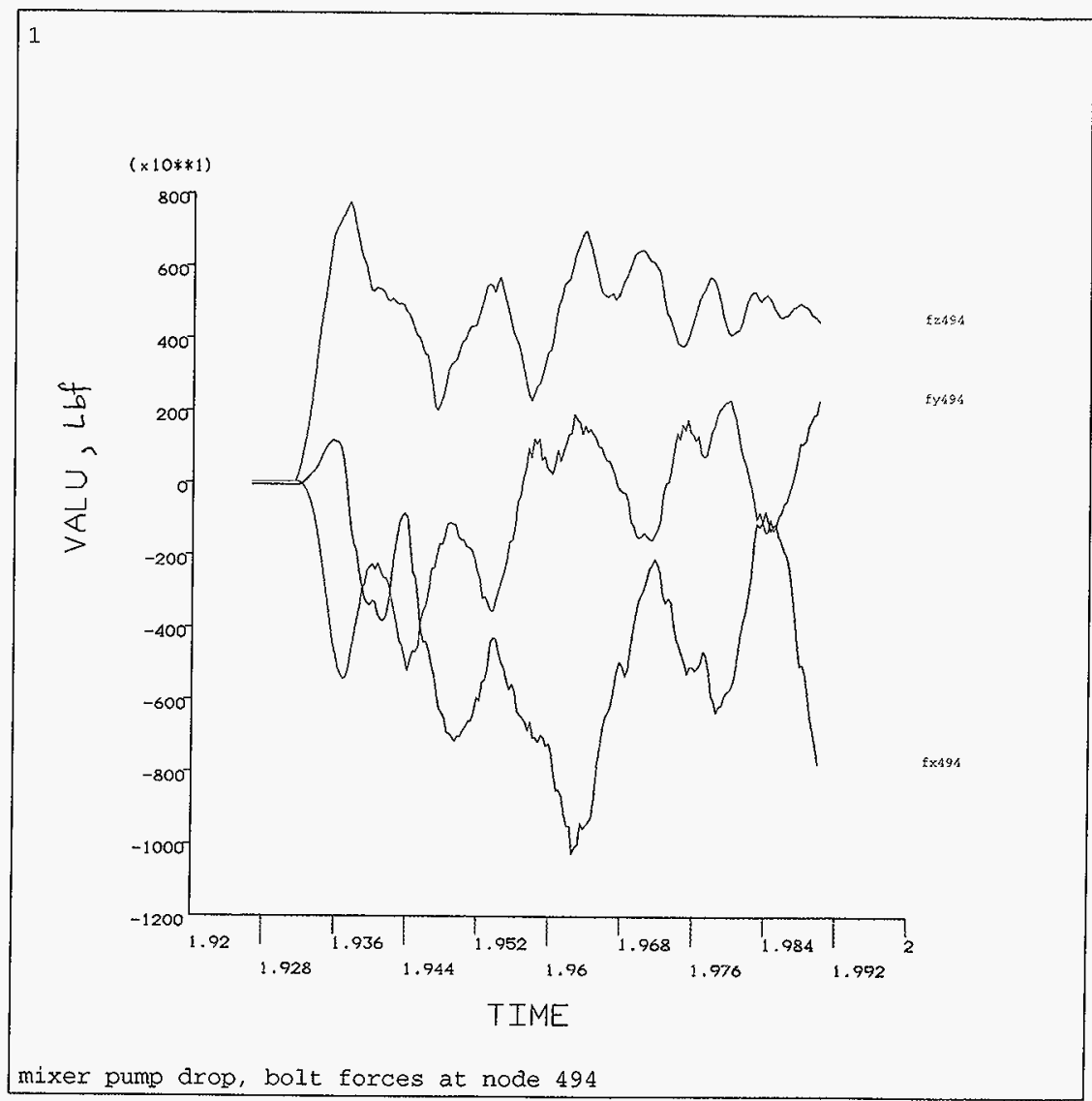

ANSYS 5.2

AUG 261997

$09: 23: 17$

PLOT NO. 13

POST26

$\mathrm{ZV}=1$

$\mathrm{DIST}=.75$

$\mathrm{XF}=.5$

$\mathrm{YF}=.5$

$\mathrm{ZF}=.5$

VUP $=\mathrm{Z}$

$\mathrm{Z}$-BUFFER 


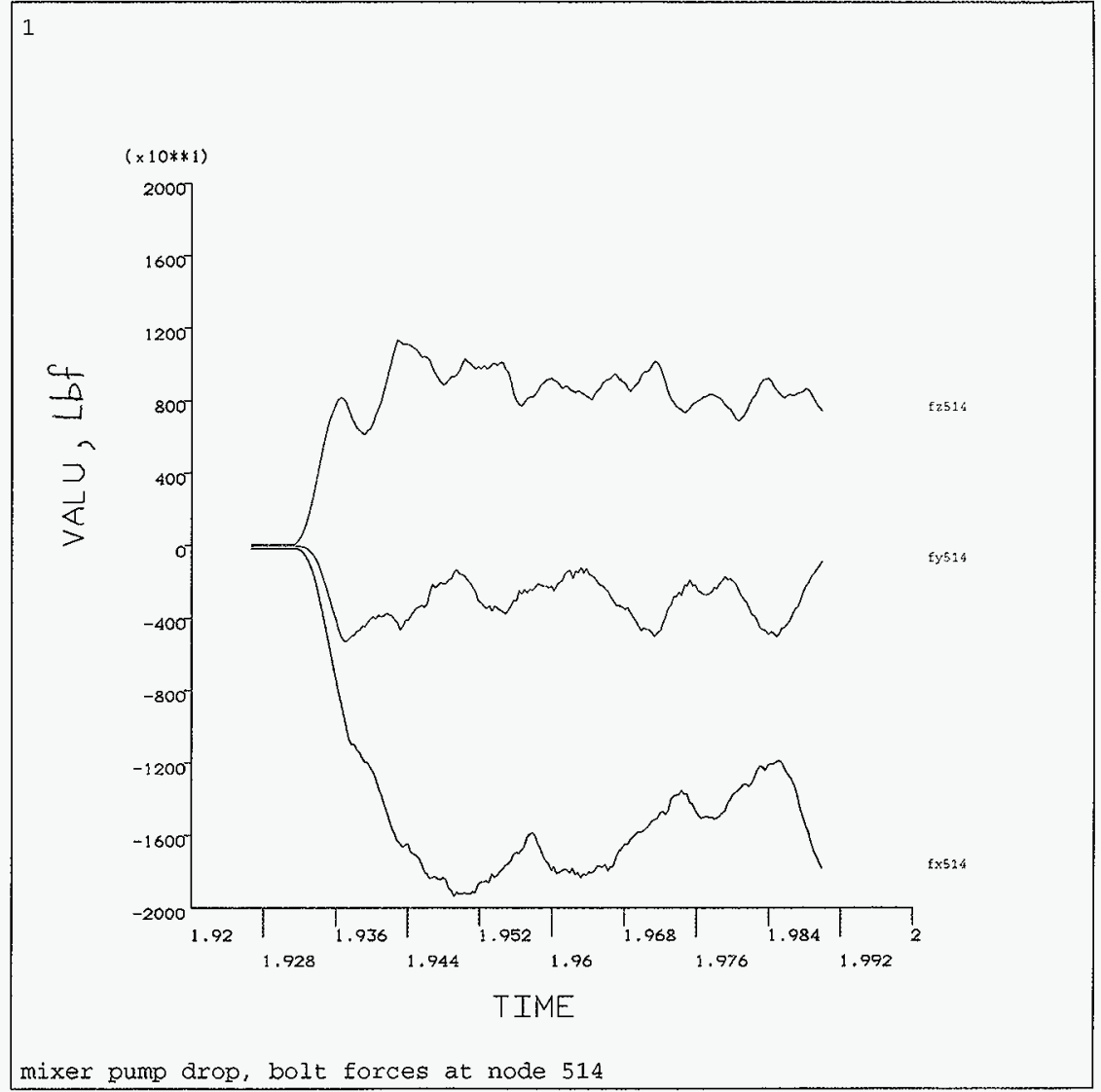

ANSYS 5.2

AUG 261997

$09: 24: 32$

PLOT NO. 14

POST26

ZV $=1$

DIST $=.75$

$\mathrm{XF}=.5$

$\mathrm{YF}=.5$

$\mathrm{ZF}=.5$

$\mathrm{VUP}=\mathrm{Z}$

$Z-B U F F E R$

FIGURE 14 


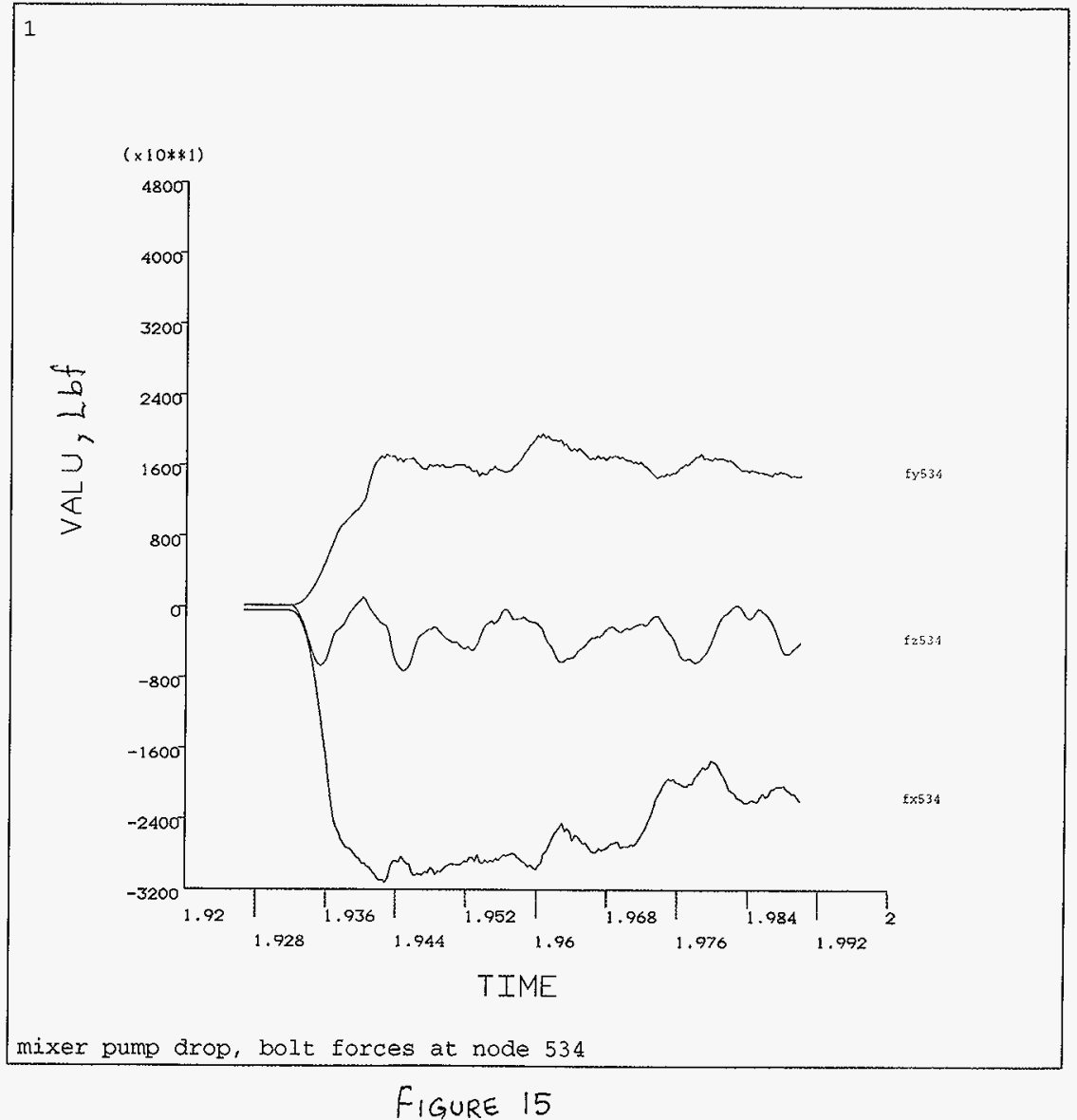

ANSYS 5.2

AUG 261997

$09: 25: 54$

PLOT NO. 15

POST26

$\mathrm{ZV}=1$

DIST $=.75$

$\mathrm{XF}=.5$

$\mathrm{YF}=.5$

$\mathrm{ZF}=.5$

$\mathrm{VUP}=\mathrm{Z}$

$Z$-BUFFER

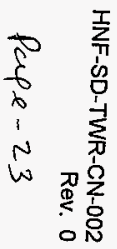




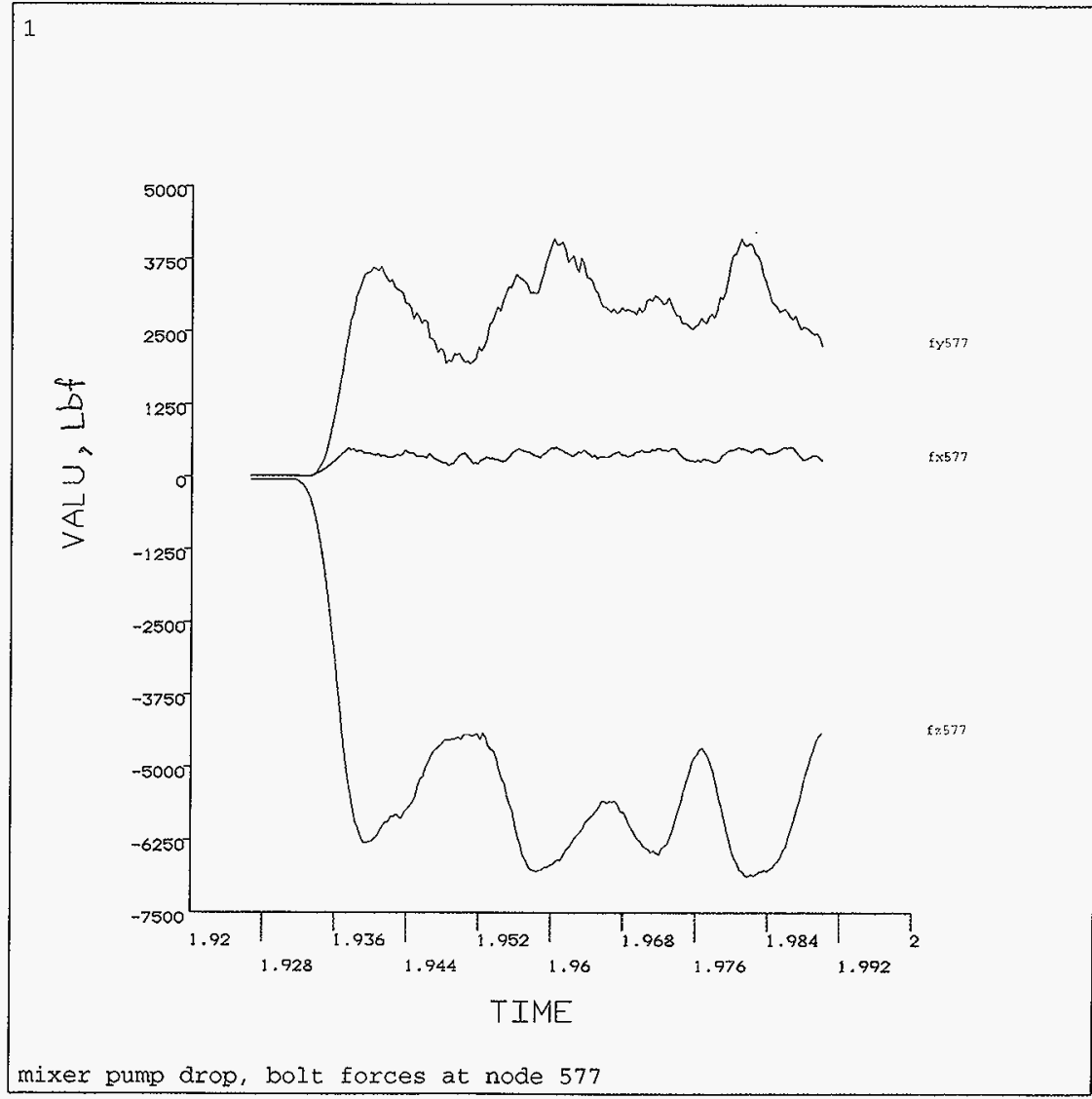

ANSYS 5.2

AUG $26 \quad 1997$

$09: 27: 12$

PLOT NO, 16

POST2 6

$\mathrm{zV}=1$

$\mathrm{DIST}=.75$

$\mathrm{XF}=.5$

$Y F=.5$

$Z F=.5$

VUP $=Z$

z-BUFFER

\section{FIGURE 16}

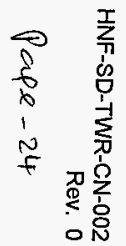




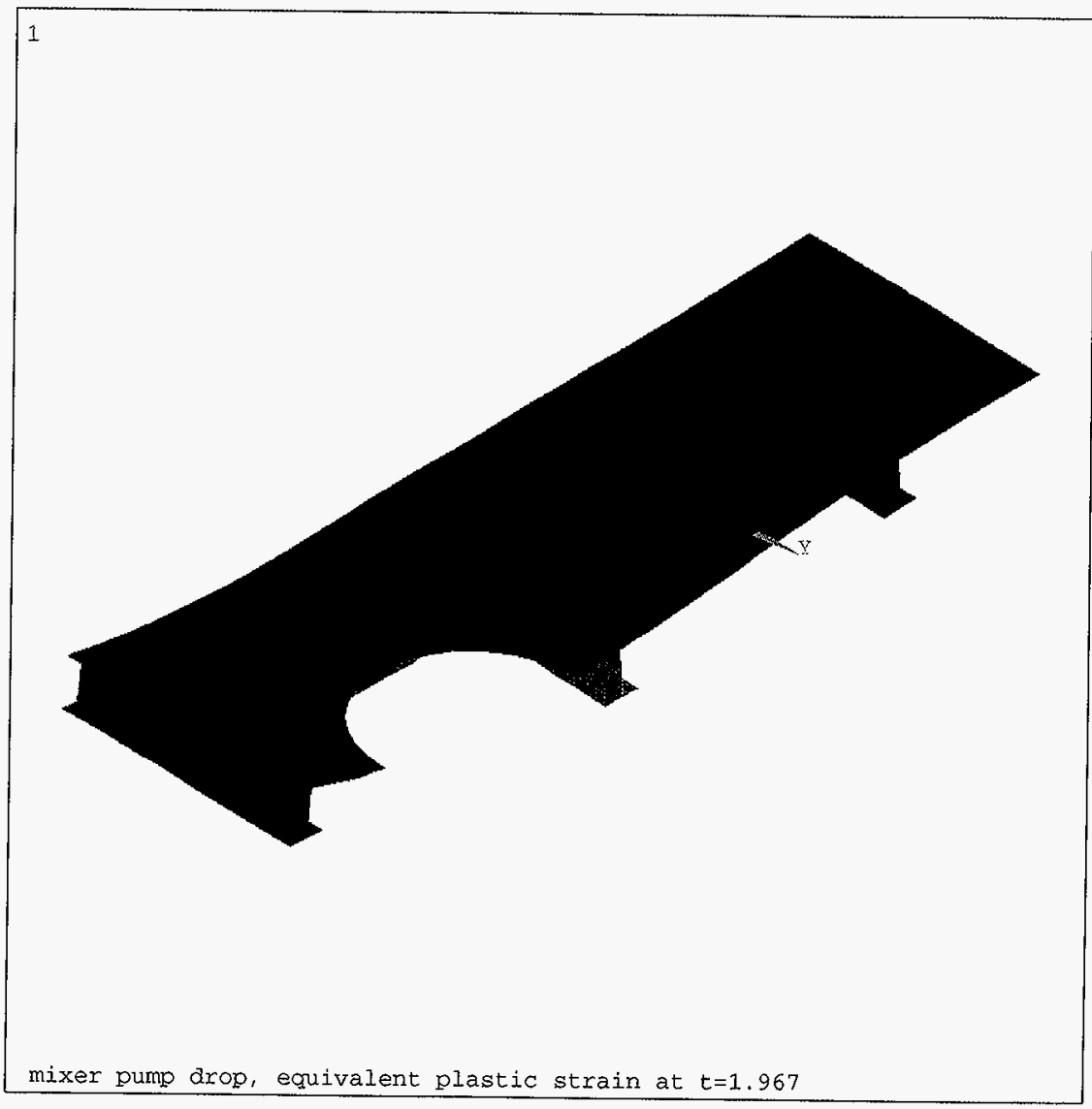

ANSYS 5.2

AUG 261997

$09: 34: 09$

PLOT NO. 18

NODAI SOLUTION

STEP $=3$

SUB $=369$

TIME $=1.967$

NLEPEQ (AVG)

TOP

DMX $=3.833$

SMX $=.041731$

0

.004637

.009274

.01391

.018547

.023184

.

$\quad .032457$

.037094

.041731 


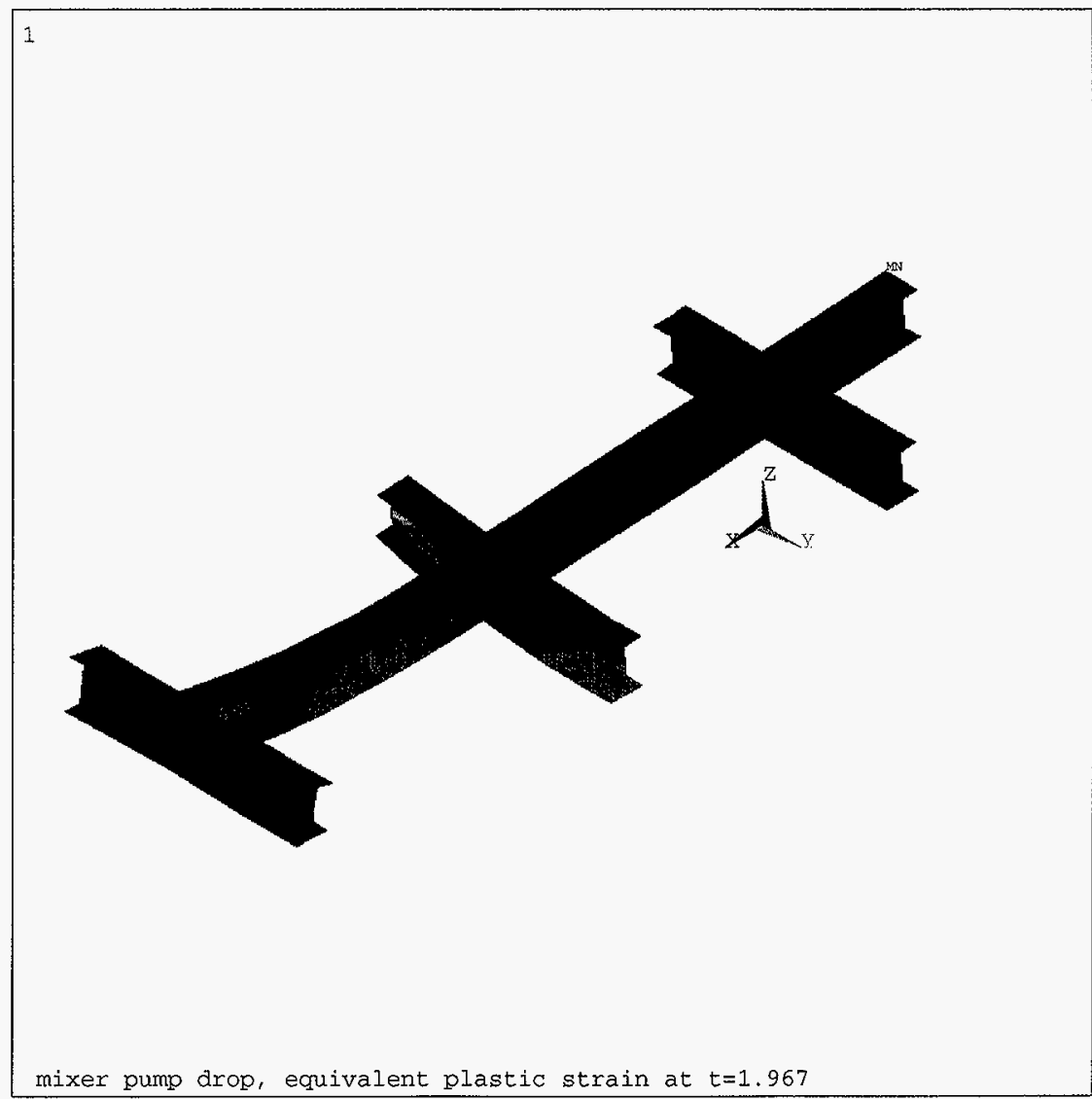

ANSYS 5.2

AUG 261997

$09: 35: 14$

PLOT NO. 19

NODAI SOLUTION

STEP $=3$

SUB $=369$

TIME $=1.967$

NLEPEQ (AVG)

TOP

$D M X=3.65$

$S M X=.041731$

0

.004637

.009274

.01391

... 018547

.023184

파라. .027821

.032457

.037094

.041731

FIGURE 18 


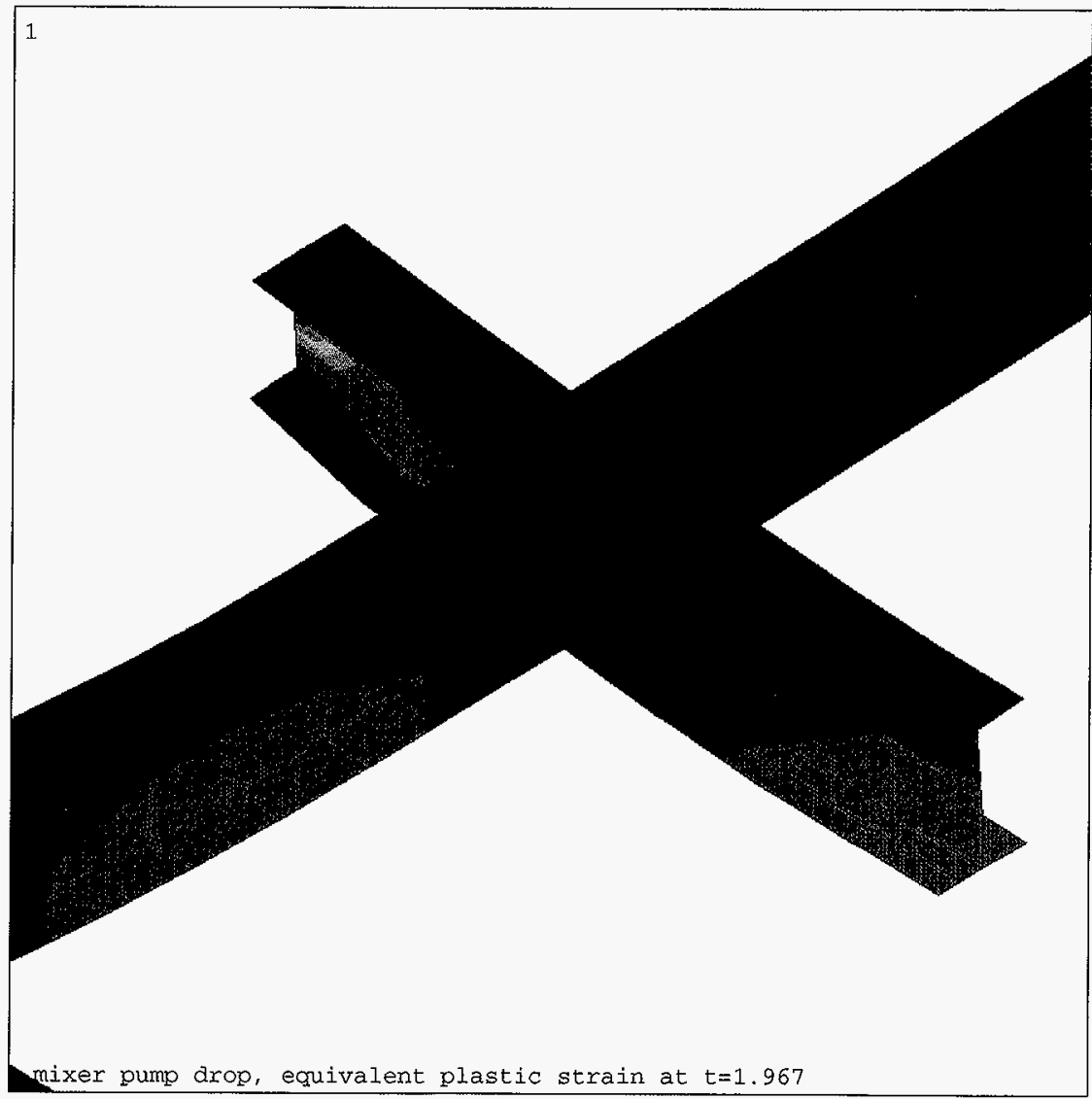

ANSYS 5.2

AUG 261997

$09: 35: 53$

PLOT NO. 20

NODAL SOLUTION

STEP $=3$

SUB $=369$

TIME $=1.967$

NLEPEQ (AVG)

TOP

$\mathrm{DMX}=3.65$

$\mathrm{SMX}=.041731$

0

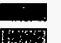

.004637

(1)

.009274

.01391

.018547

.

023184

.027821

प.032457

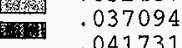




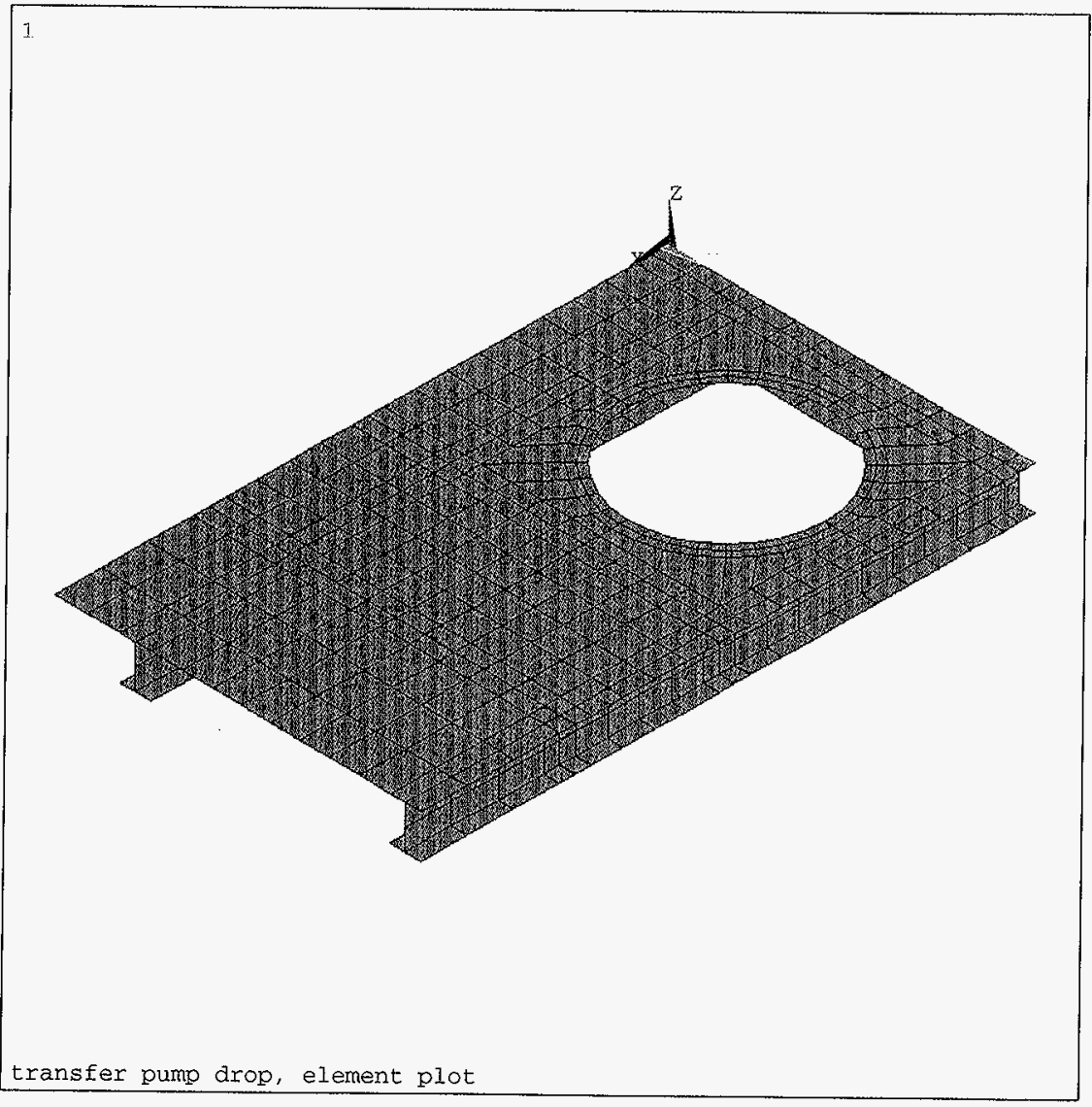

ANSYS 5.2

SEP 21997

$13: 19: 06$

PLOT NO.

ELEMENTS

TYPE NUM

$\mathrm{XV}=1$

$Y V=1$

$\mathrm{ZV}=1$

DIST $=96.975$

$\mathrm{XF}=77.675$

$Y F=47$

$\mathrm{ZF}=-5.45$

VUP $=\mathrm{Z}$

$Z$-BUFFER 


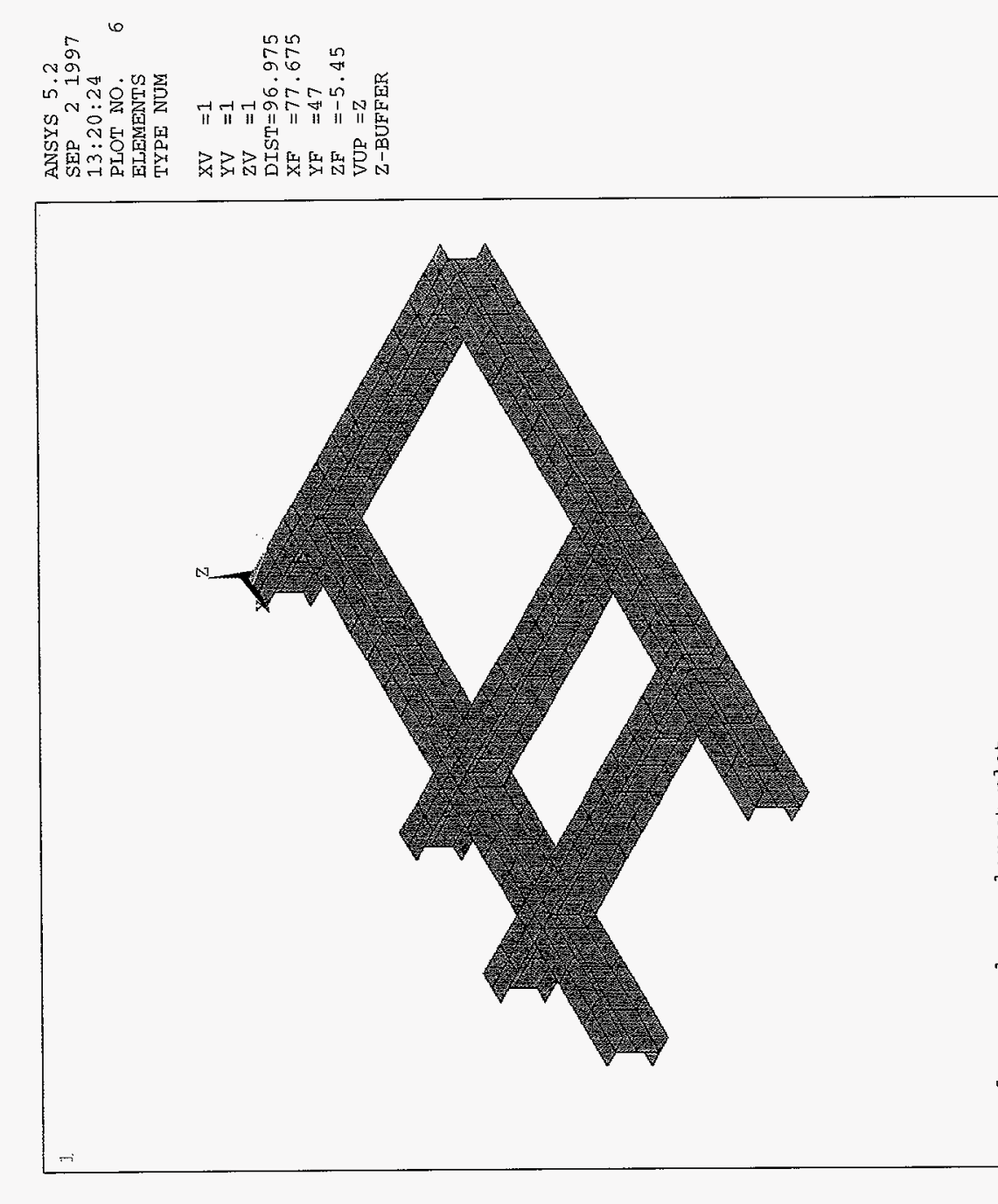




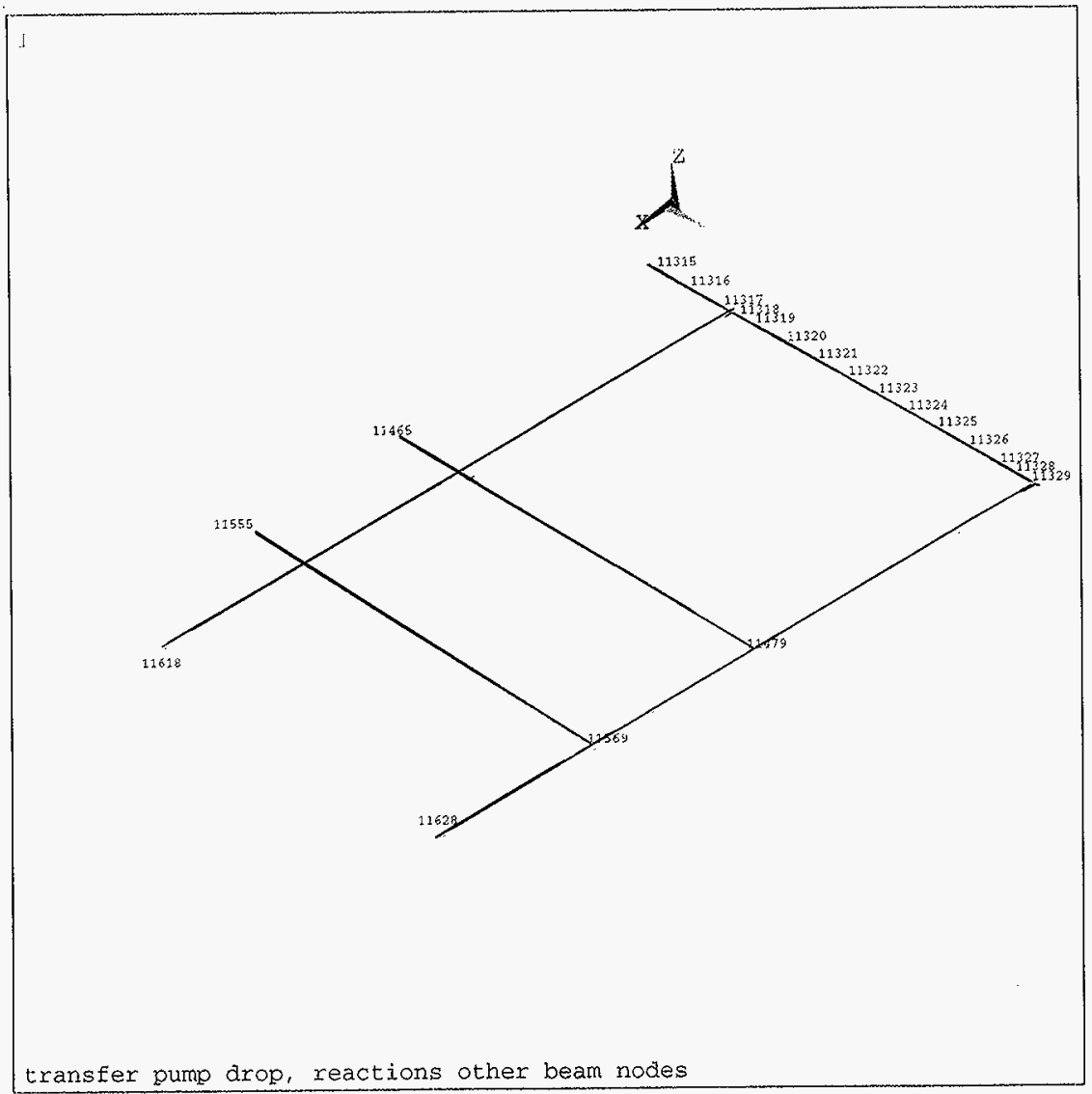

ANSYS 5.2

SEP 21997

$13: 17: 19$

PLOT NO.

ELEMENTS

TYPE NUM

$\mathrm{XV}=1$

$Y V=1$

$\mathrm{zV}=1$

DIST $=95.419$

$\mathrm{XF}=79.675$

$\mathrm{YF}=47$

$\mathrm{ZF}=-10.92$

VUP $=2$

$\mathrm{Z}$-BUFFER 


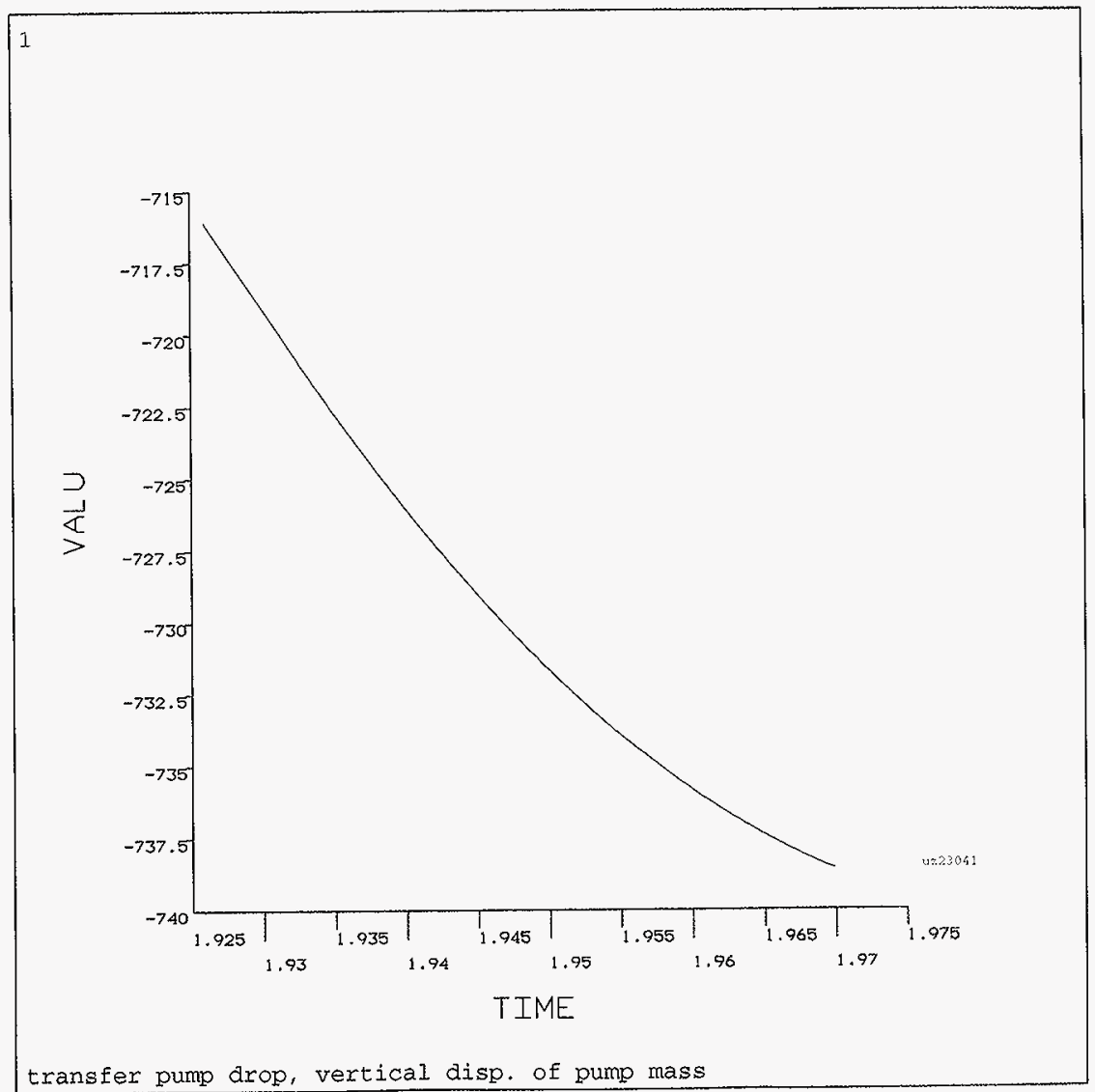

ANSYS 5.2

SEP $\quad 4 \quad 1997$

$07: 50: 24$

PLOT NO. 2

POST26

$\mathrm{zV}=1$

DIST $=.75$

$\mathrm{XF}=.5$

$\mathrm{YF}=.5$

$\mathrm{ZF}=.5$

Z-BUFFER

transfer pump drop, vertical disp. of pump mass

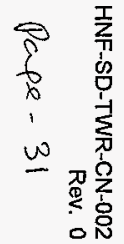

FIGURE 23 


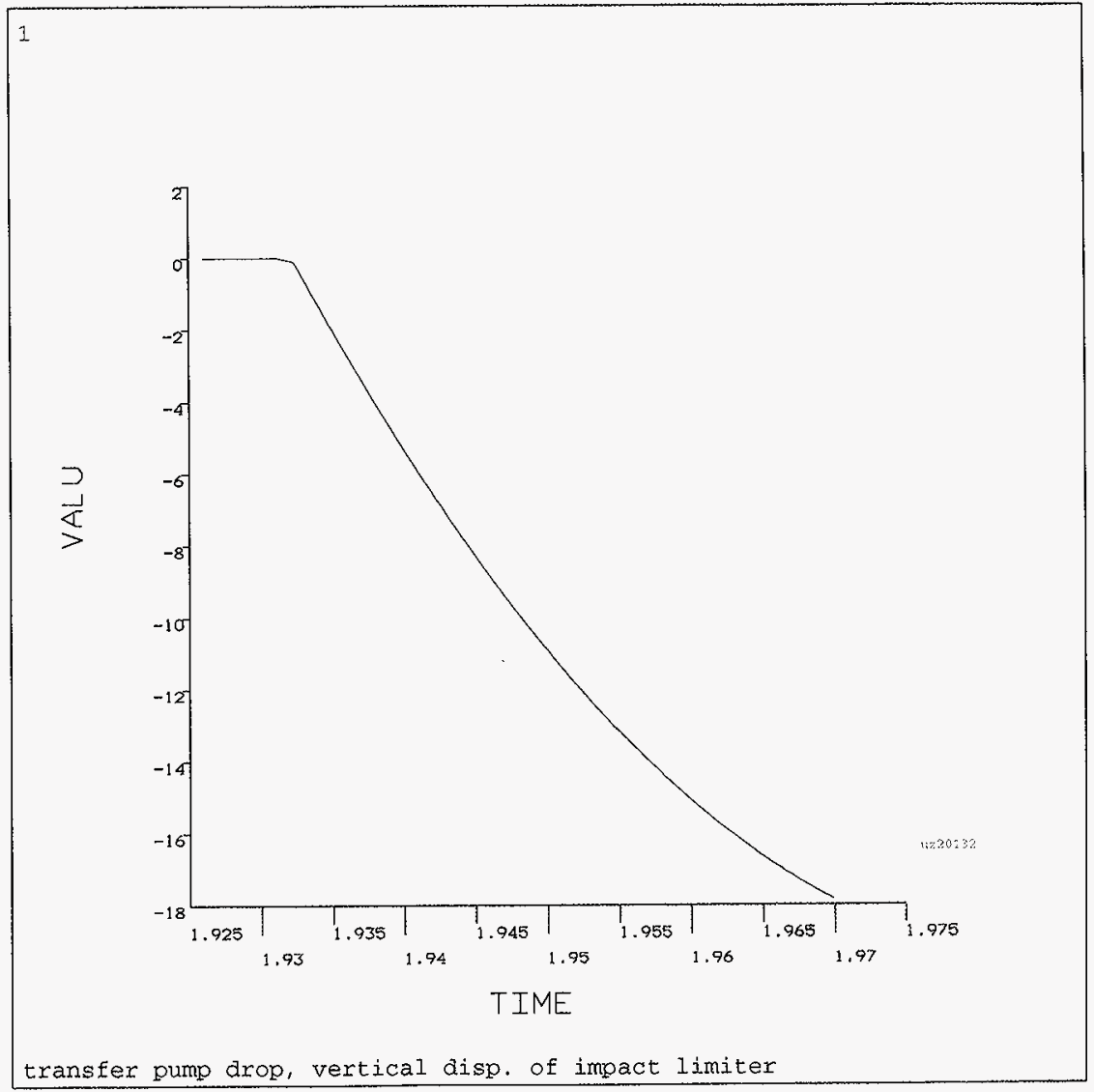

ANSYS 5.2

SEP 41997

07:51:29

PLOT NO.

POST2 6

$\mathrm{ZV}=1$

DIST $=.75$

$\mathrm{XF}=.5$

$\mathrm{YF}=.5$

$Z F=.5$

Z-BUFFER 


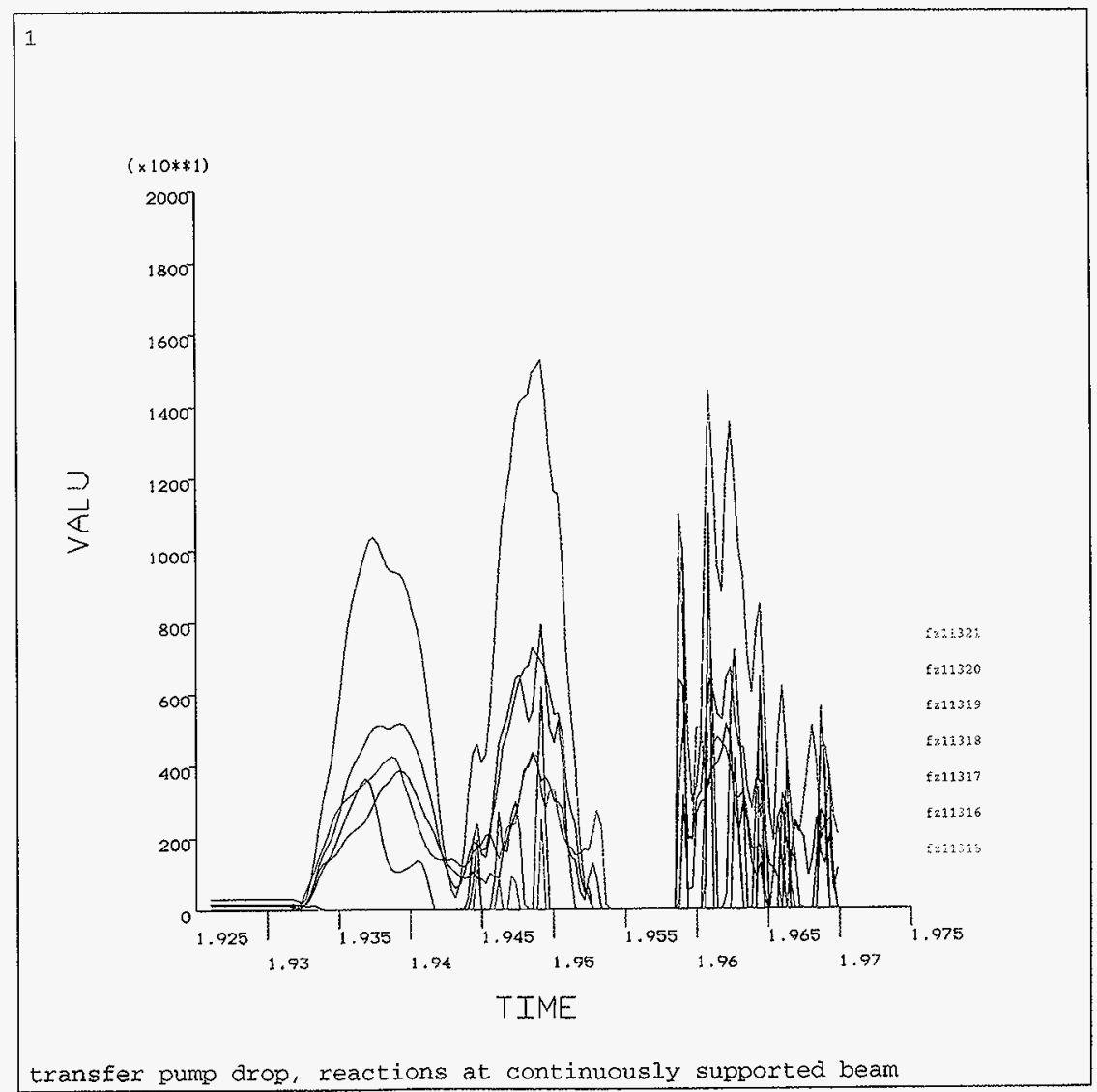

ANSYS 5.2

SEP 41997

$08: 01: 24$

PLOT NO. 5

POST26

$\mathrm{zV}=1$

DIST $=.75$

$\mathrm{XF}=.5$

$\mathrm{YF}=.5$

$\mathrm{ZF}=.5$

Z-BUFFER

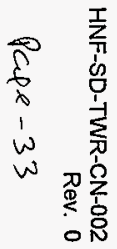

FIGURE 25 

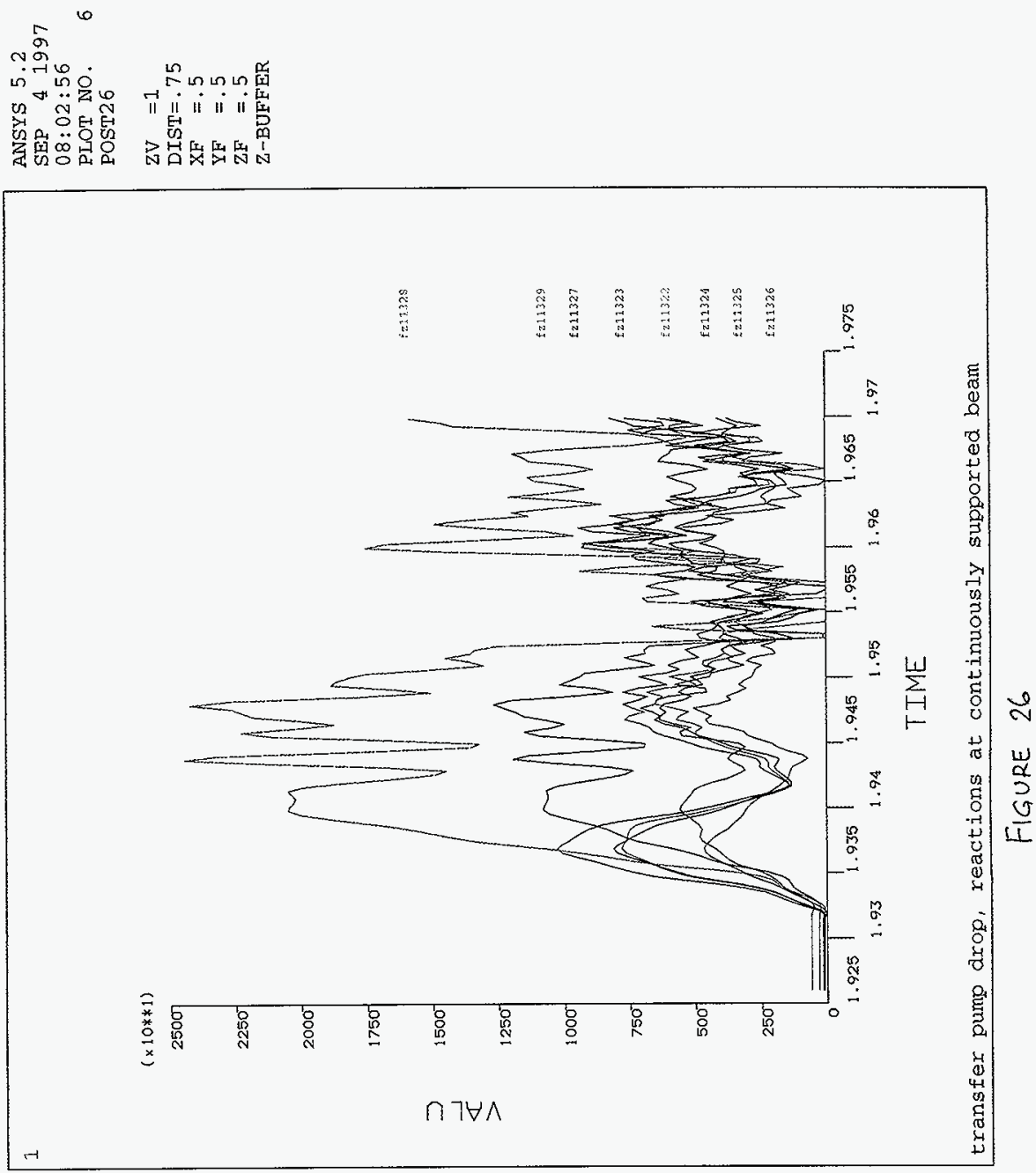


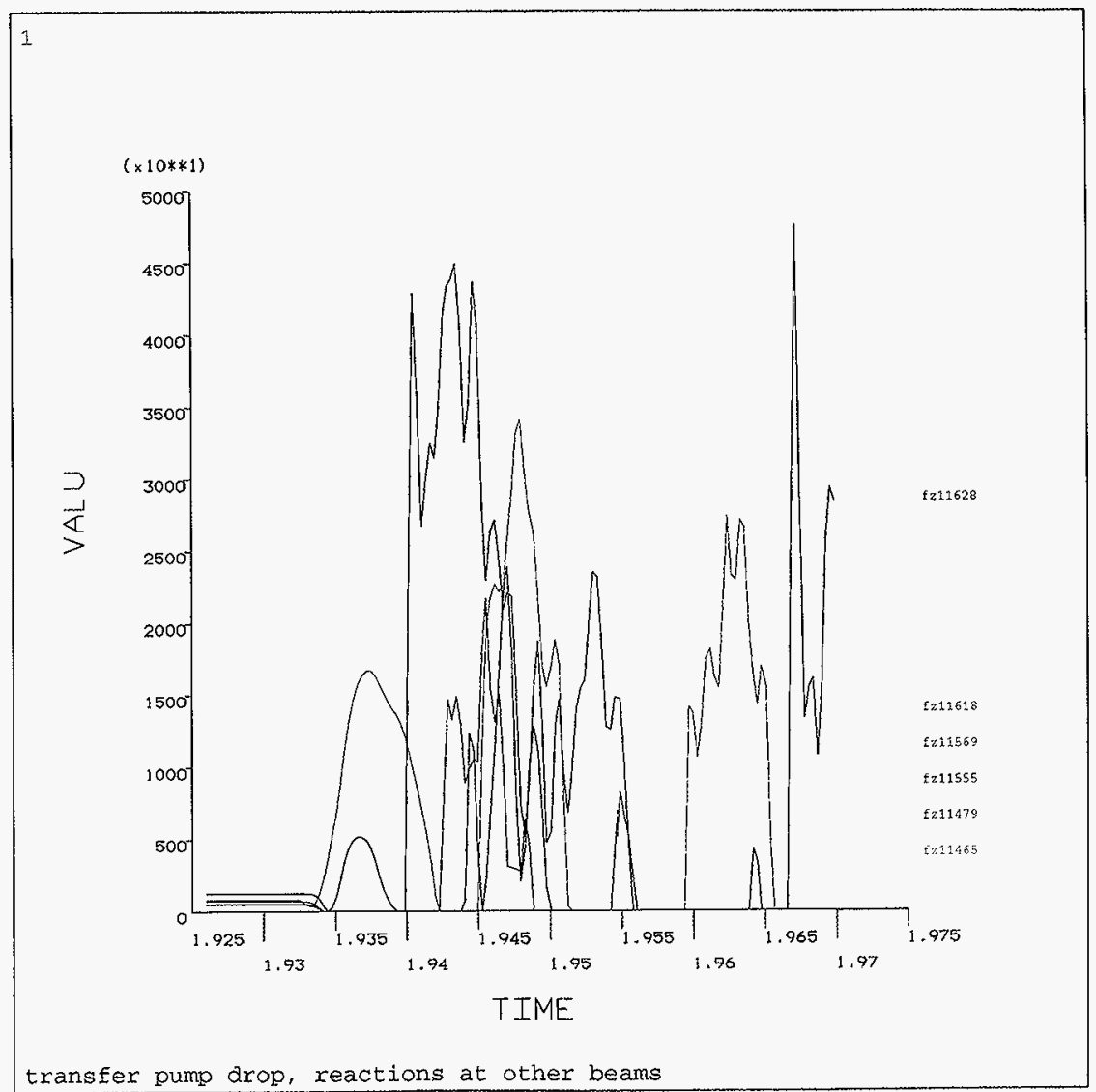

ANSYS 5.2

SEP $\quad 4 \quad 1997$

$08: 05: 07$

PLOT NO.

POST26

$$
\begin{aligned}
& \mathrm{ZV}=1 \\
& \mathrm{DIST}=.75 \\
& \mathrm{XF}=.5 \\
& \mathrm{YF}=.5 \\
& \mathrm{ZF}=.5 \\
& \mathrm{Z}-\mathrm{BUFFER}
\end{aligned}
$$



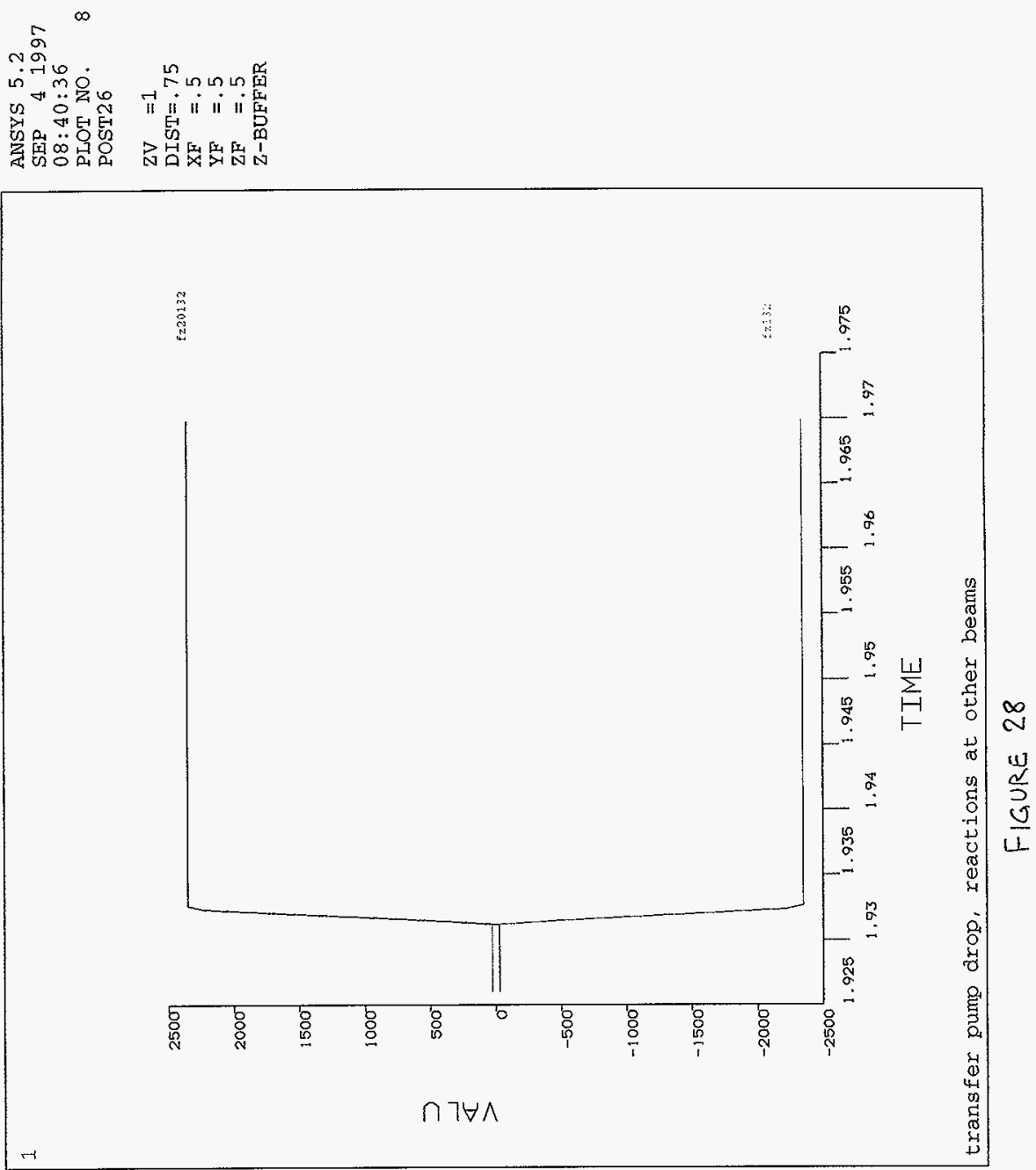


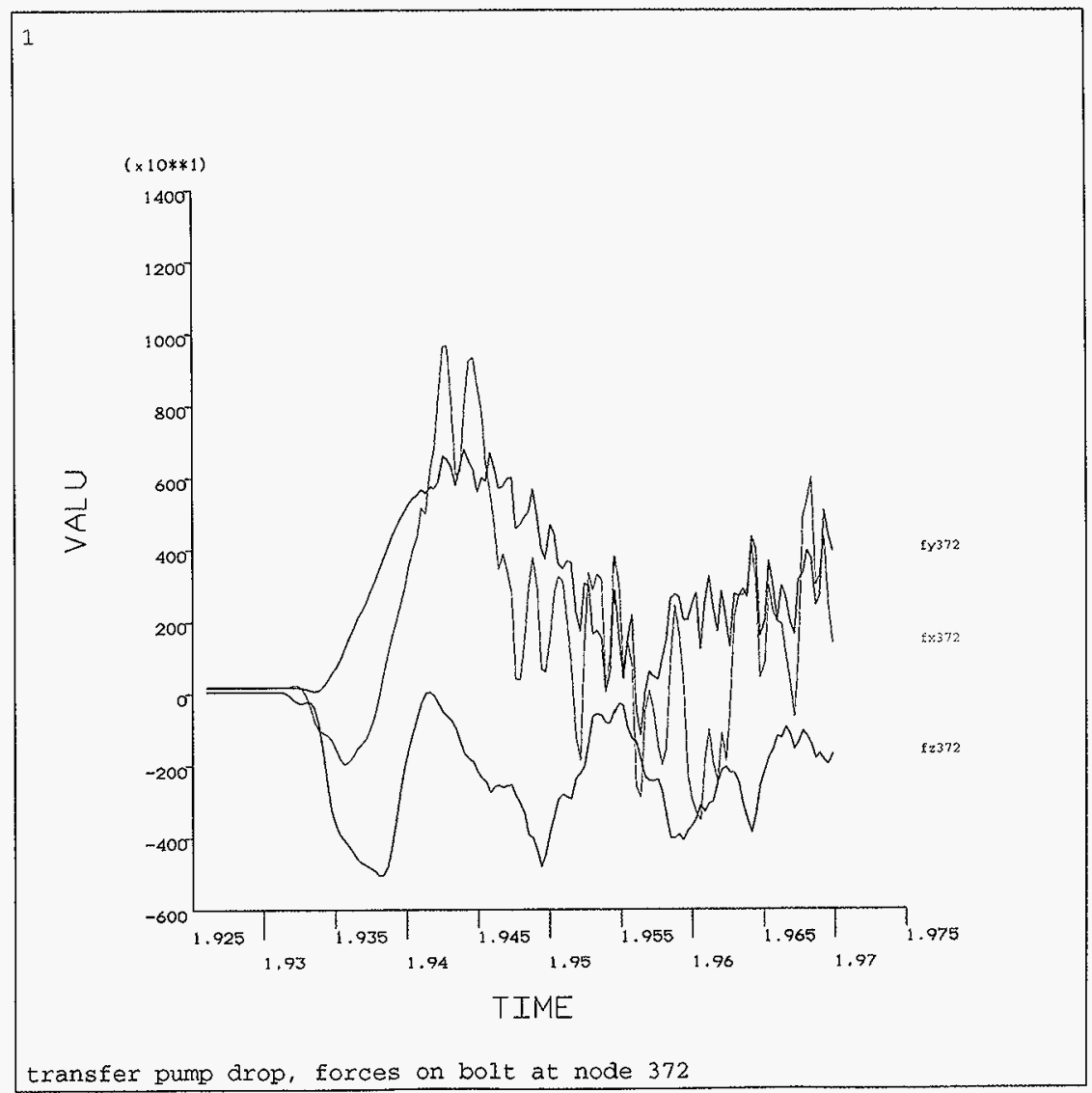

ANSYS 5.2

SEP 41997

$09: 22: 54$

PLOT NO. 10

POST26

$\mathrm{ZV}=1$

$\mathrm{DIST}=.75$

$\mathrm{XF}=.5$

$\mathrm{YF}=.5$

$\mathrm{ZF}=.5$

Z-BUFFER

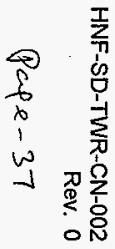



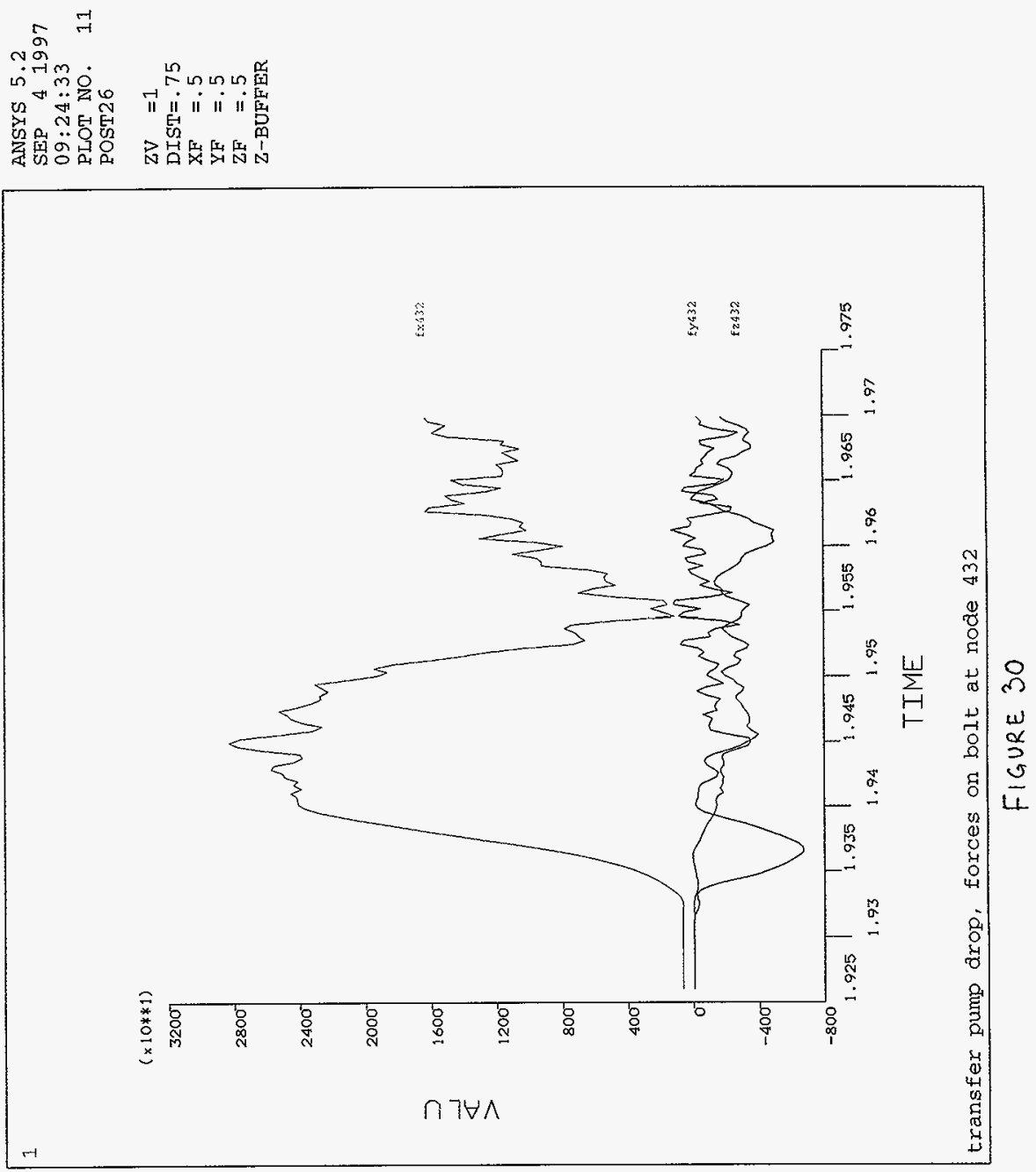


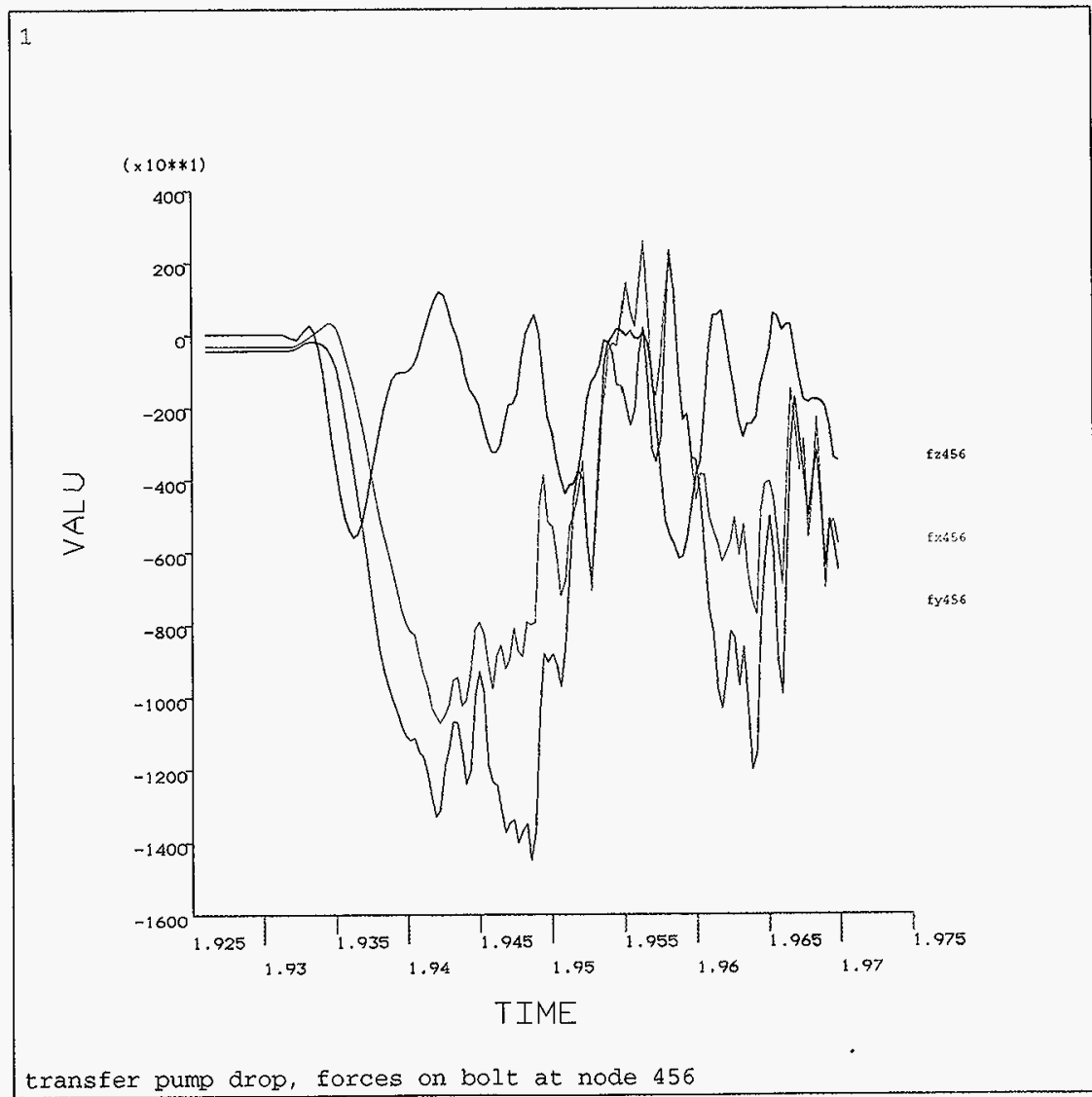

ANSYS 5.2

SEP 41997

$09: 25: 42$

PLOT NO. 12

POST2 6

$\mathrm{zV}=1$

DIST $=.75$

$\mathrm{XF}=.5$

$\mathrm{YF}=.5$

$\mathrm{ZF}=.5$

Z-BUFFER 


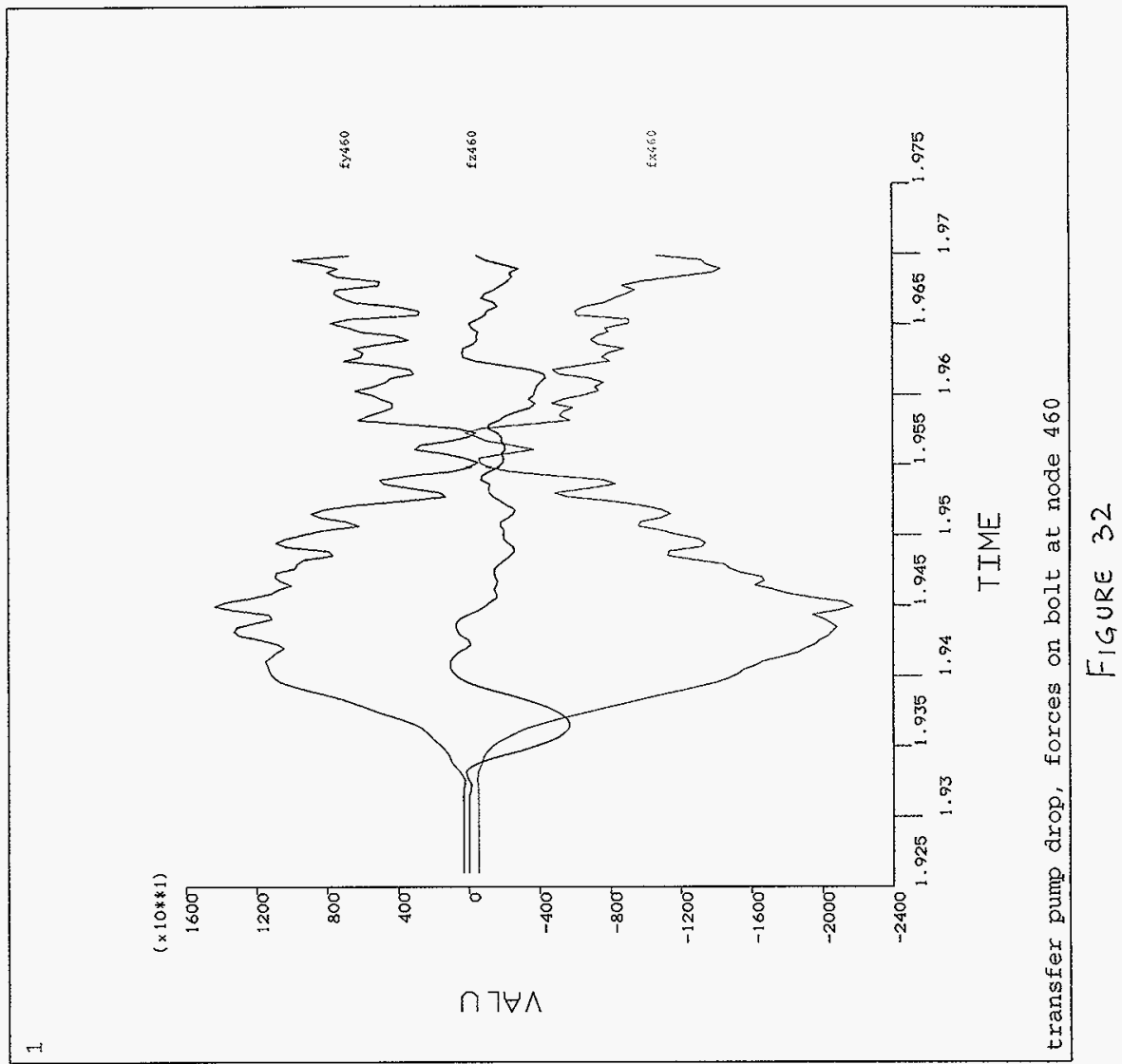



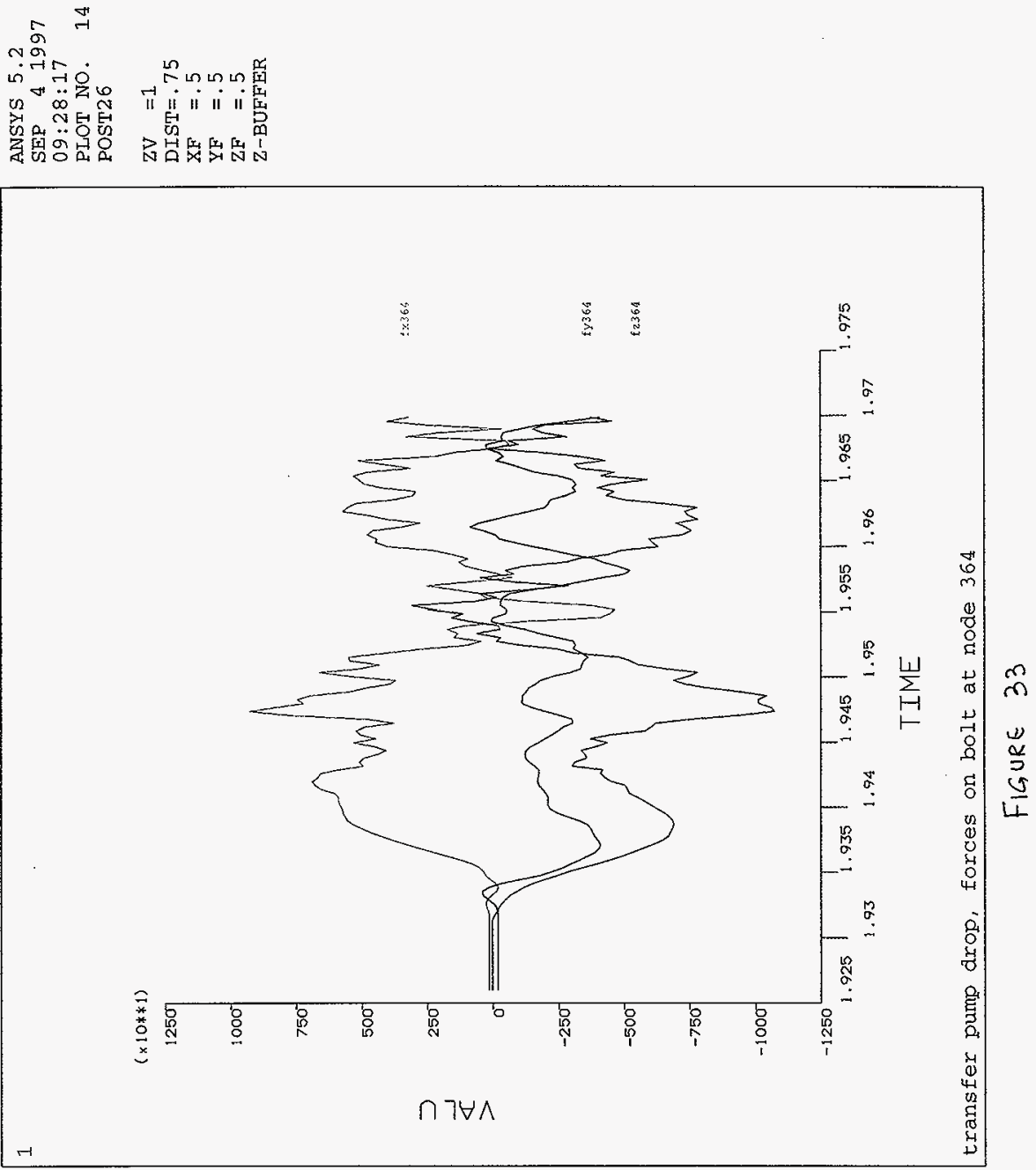
HNF-SD-TWR-CN-002

Rev. 0

Pape-42
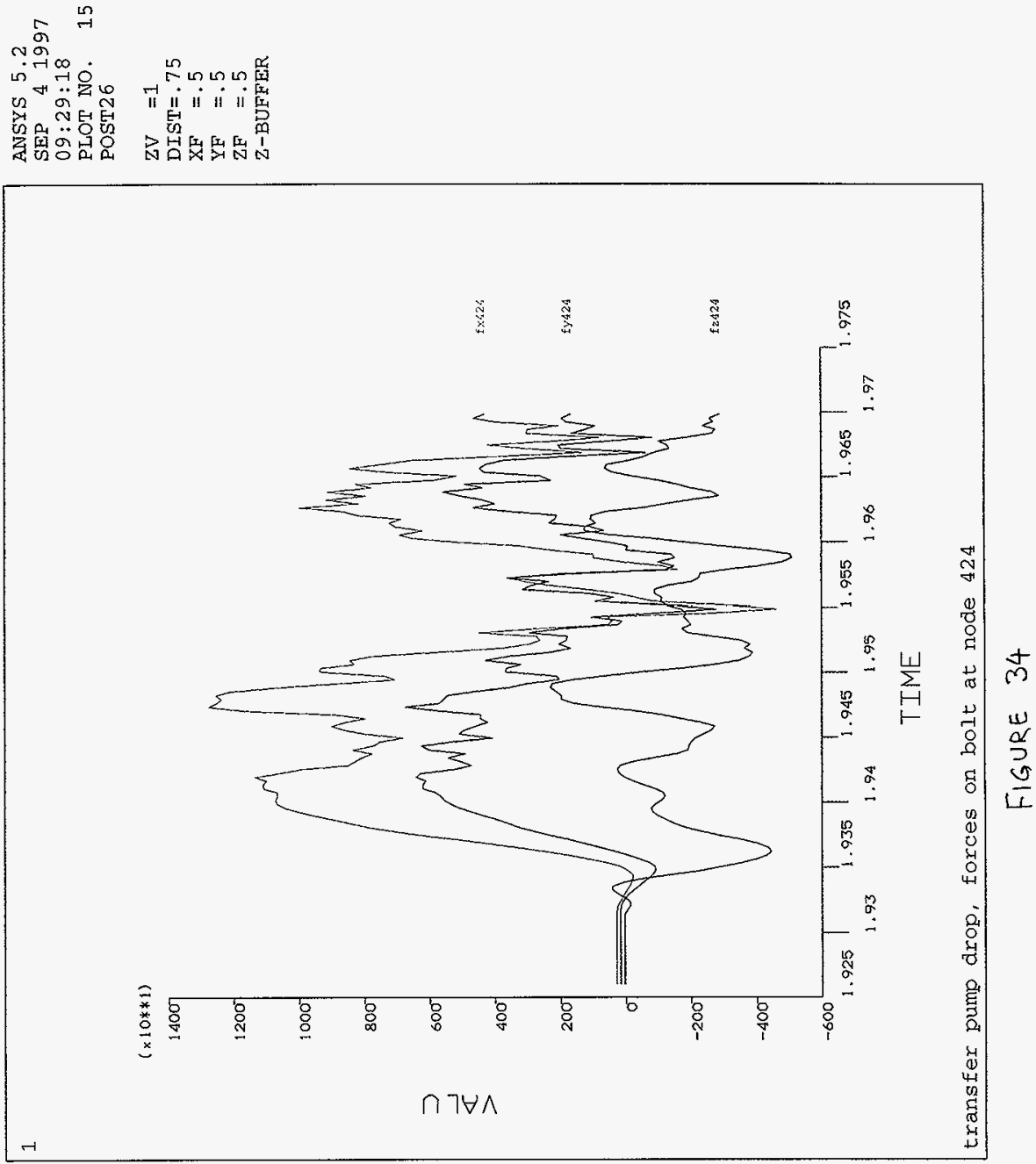

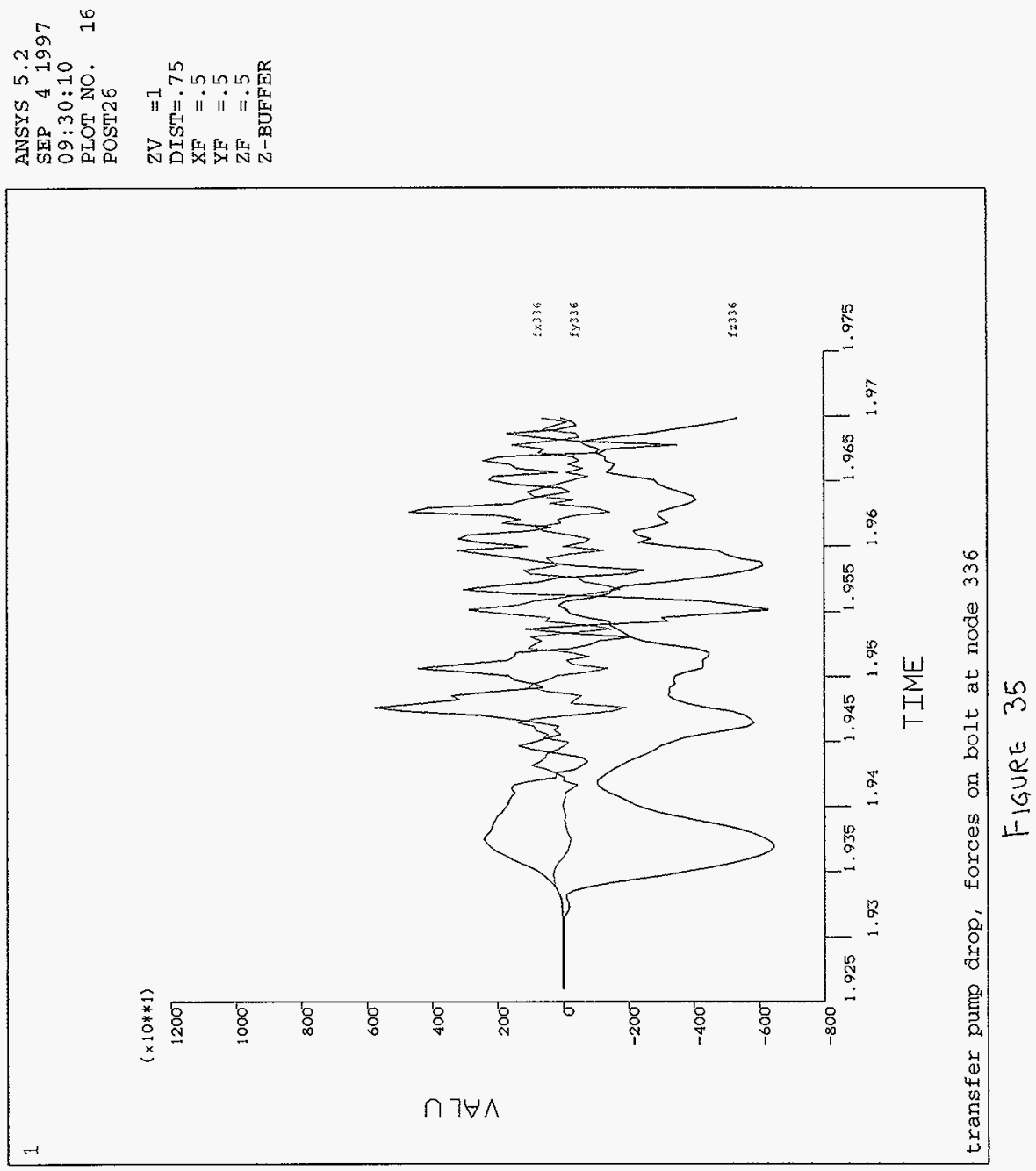


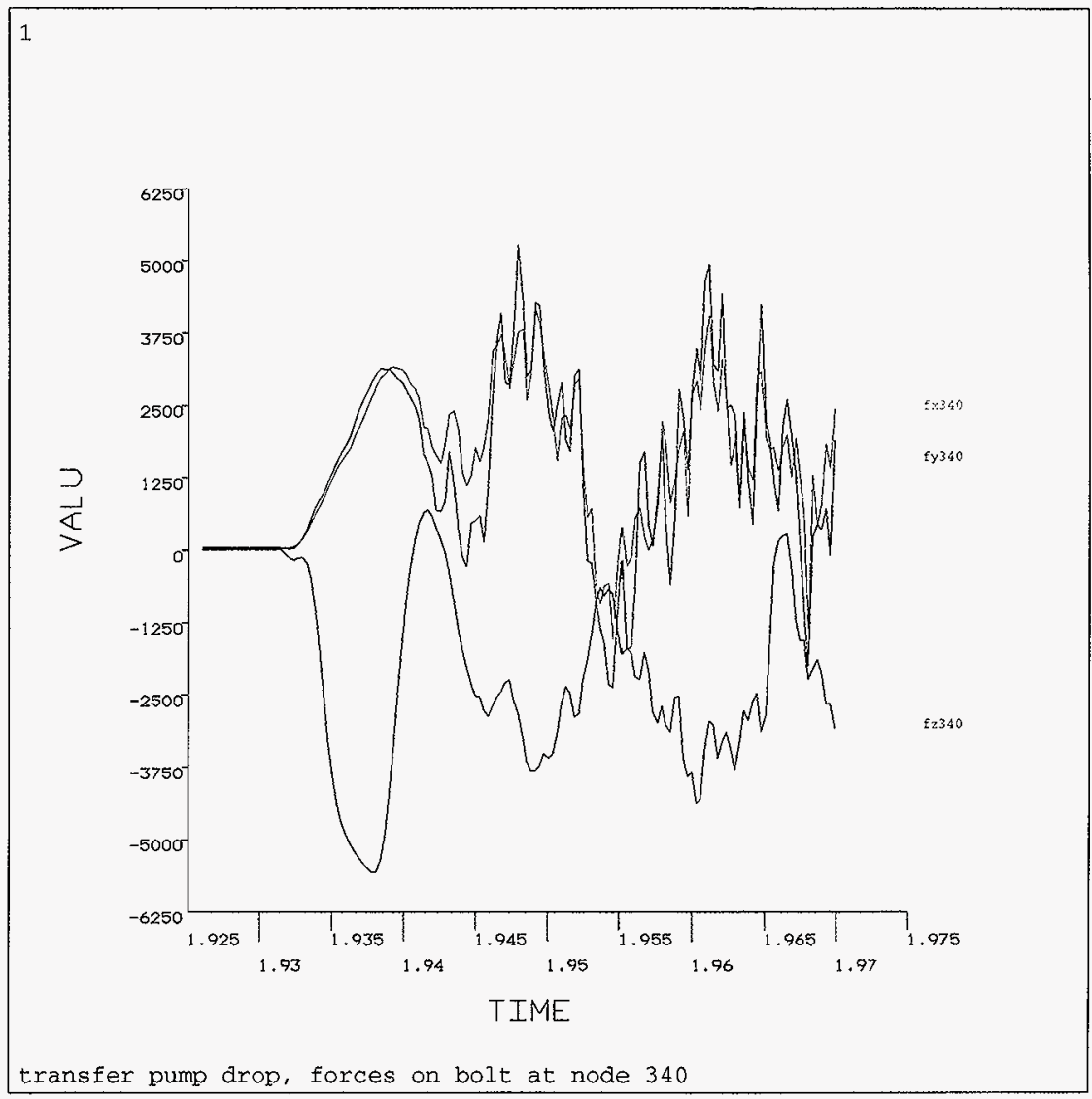

ANSYS 5.2

SEP 41997

$09: 31: 02$

PLOT NO. 17

POST26

$\mathrm{ZV}=1$

$\mathrm{DIST}=.75$

$\mathrm{XF}=.5$

$Y F=.5$

$\mathrm{ZF}=.5$

Z-BUFFER 


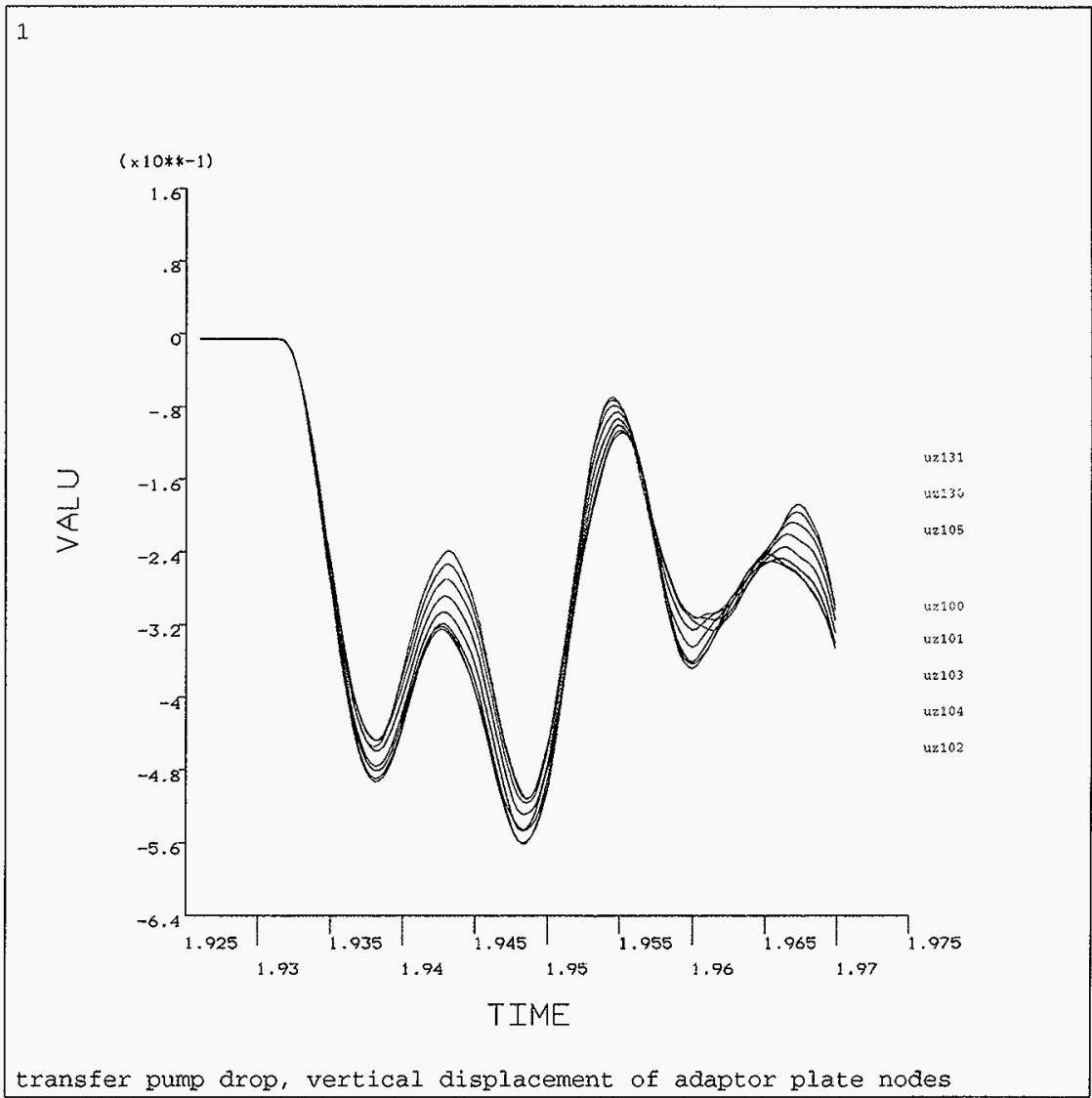

ANSYS 5.2

SEP $4 \quad 1997$

$09: 37: 56$

PLOT NO. 18

POST26

$\mathrm{ZV}=1$

DIST $=.75$

$\mathrm{XF}=.5$

$\mathrm{YF}=.5$

$\mathrm{ZF}=.5$

Z-BUFFER

\section{Figure 37}




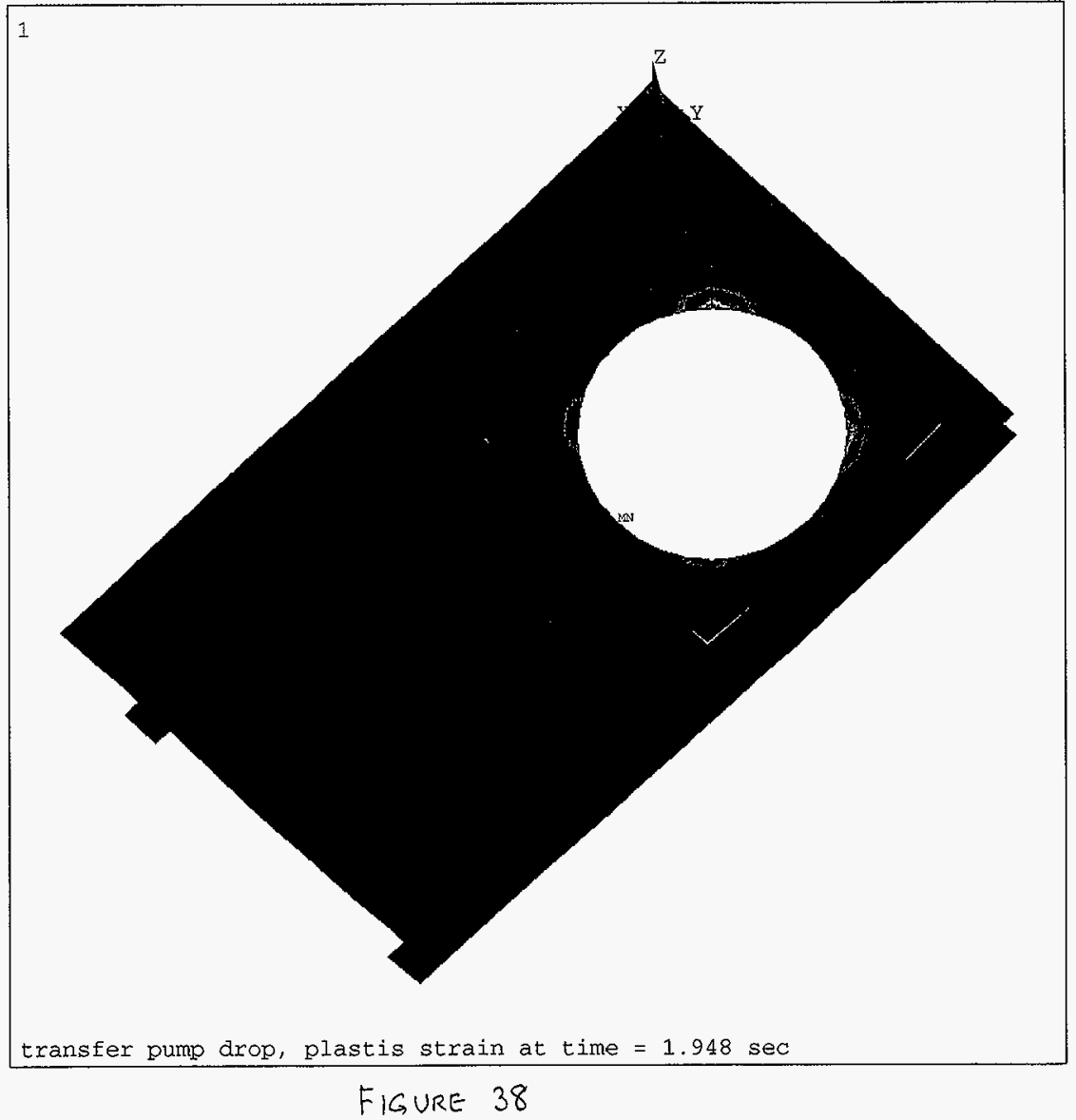

ANSYS 5.2

SEP 41997

$09: 47: 17$

PLOT NO. 19

NODAL SOLUTION

STEP $=3$

SUB $=180$

TIME $=1.948$

NLEPEQ (AVG)

TOP

$\mathrm{MMX}=.55733$

SMX $=.195 \mathrm{E}-03$

0

- $216 \mathrm{E}-04$

$.433 \mathrm{E}-04$

$.649 \mathrm{E}-04$

$.866 \mathrm{E}-04$

$.108 \mathrm{E}-03$

$.130 \mathrm{E}-03$

$152 \mathrm{E}-03$

$.173 \mathrm{E}-03$

$.195 \mathrm{E}-03$ 


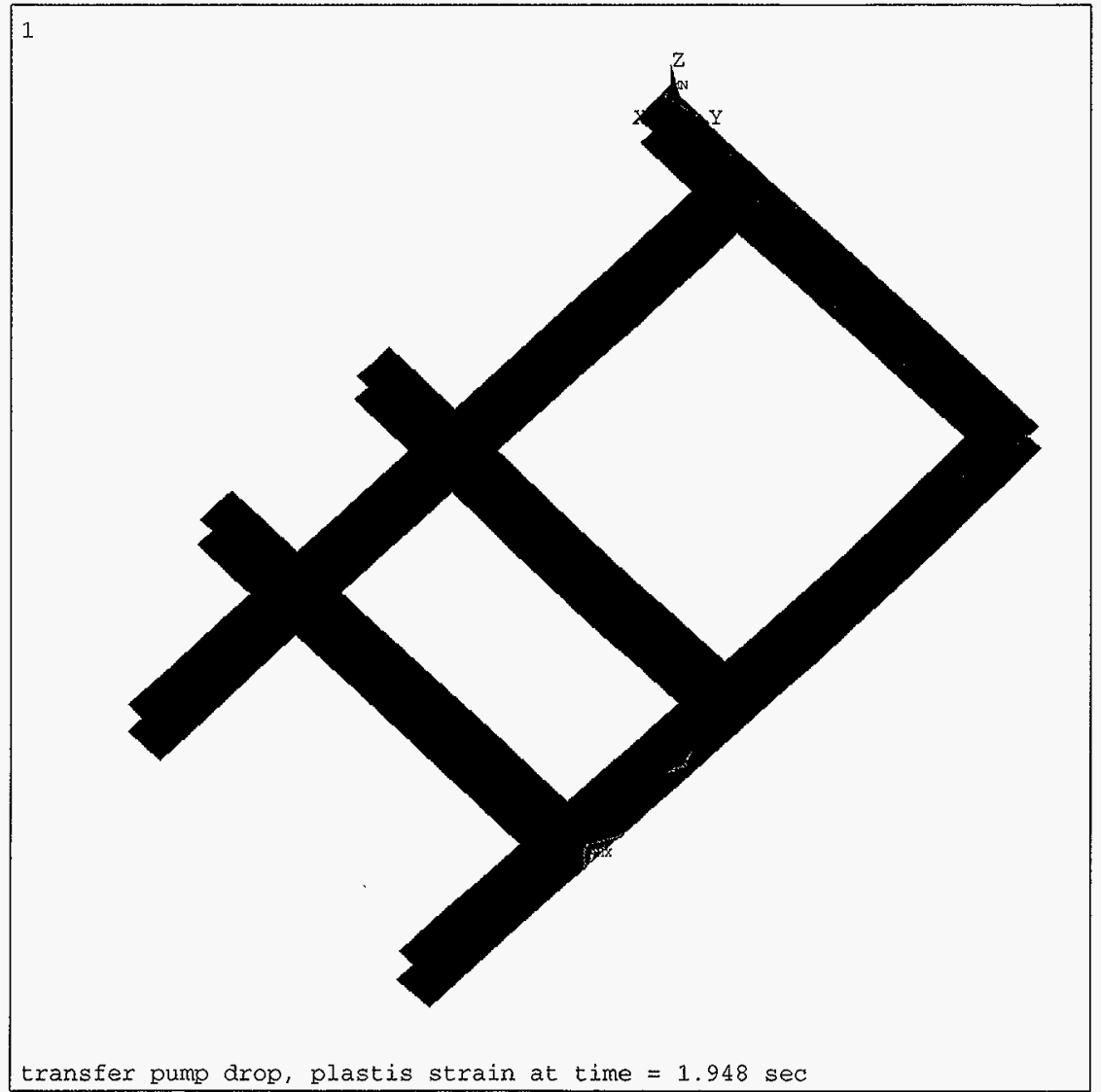

ANSYS 5.2

SEP 41997

$09: 48: 17$

PLOT NO. 20

NODAL SOLUTION

STEP $=3$

SUB $=180$

TIME $=1.948$

NLEPEQ

(AVG)

TOP

$\mathrm{DMX}=.55733$

$\mathrm{SMX}=.252 \mathrm{E}-04$

0

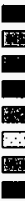

$.280 E-05$

कात $.561 \mathrm{E}-05$ $.841 \mathrm{E}-05$

$.112 \mathrm{E}-04$

$.140 \mathrm{E}-04$

$.168 \mathrm{E}-04$

$.196 \mathrm{E}-04$

$.224 \mathrm{E}-04$

$.252 E-04$ 


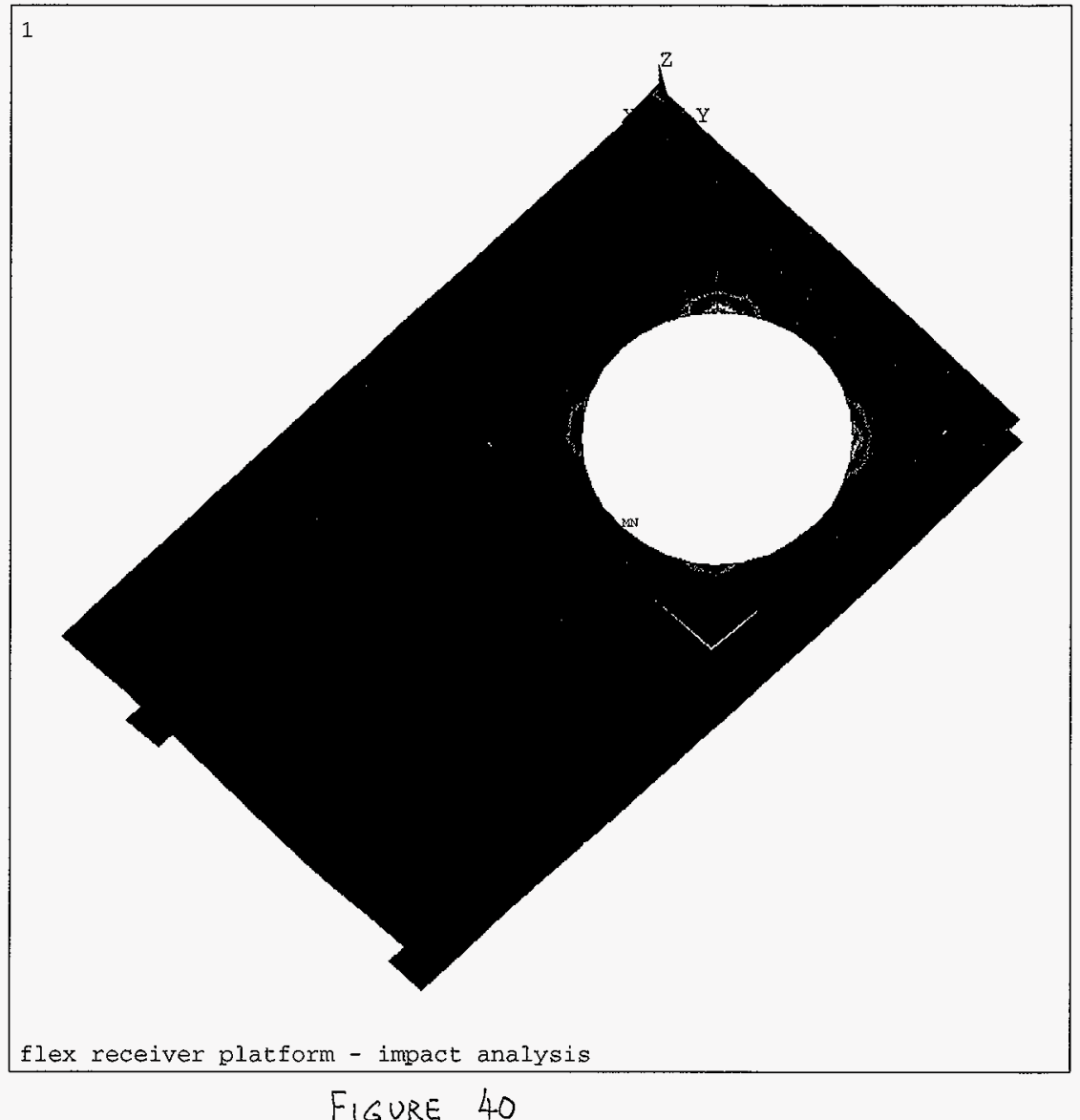

ANSYS 5.2

SEP \& 1997

$09: 52: 23$

PIJOT NO. 21

NODAL SOLUTION

STEP $=3$

SUB $=189$

TIME $=1.949$

NLEPEQ

(AVG)

TOP

$D M X=.553617$

$S M X=.195 E-03$

0

(1)

. $216 \mathrm{E}-04$

$.433 E-04$

$.649 \mathrm{E}-04$

$.866 \mathrm{E}-04$

$.108 \mathrm{E}-03$

$.130 \mathrm{E}-03$

$.152 \mathrm{E}-03$

$.173 \mathrm{E}-03$

$.195 \mathrm{E}-03$ 


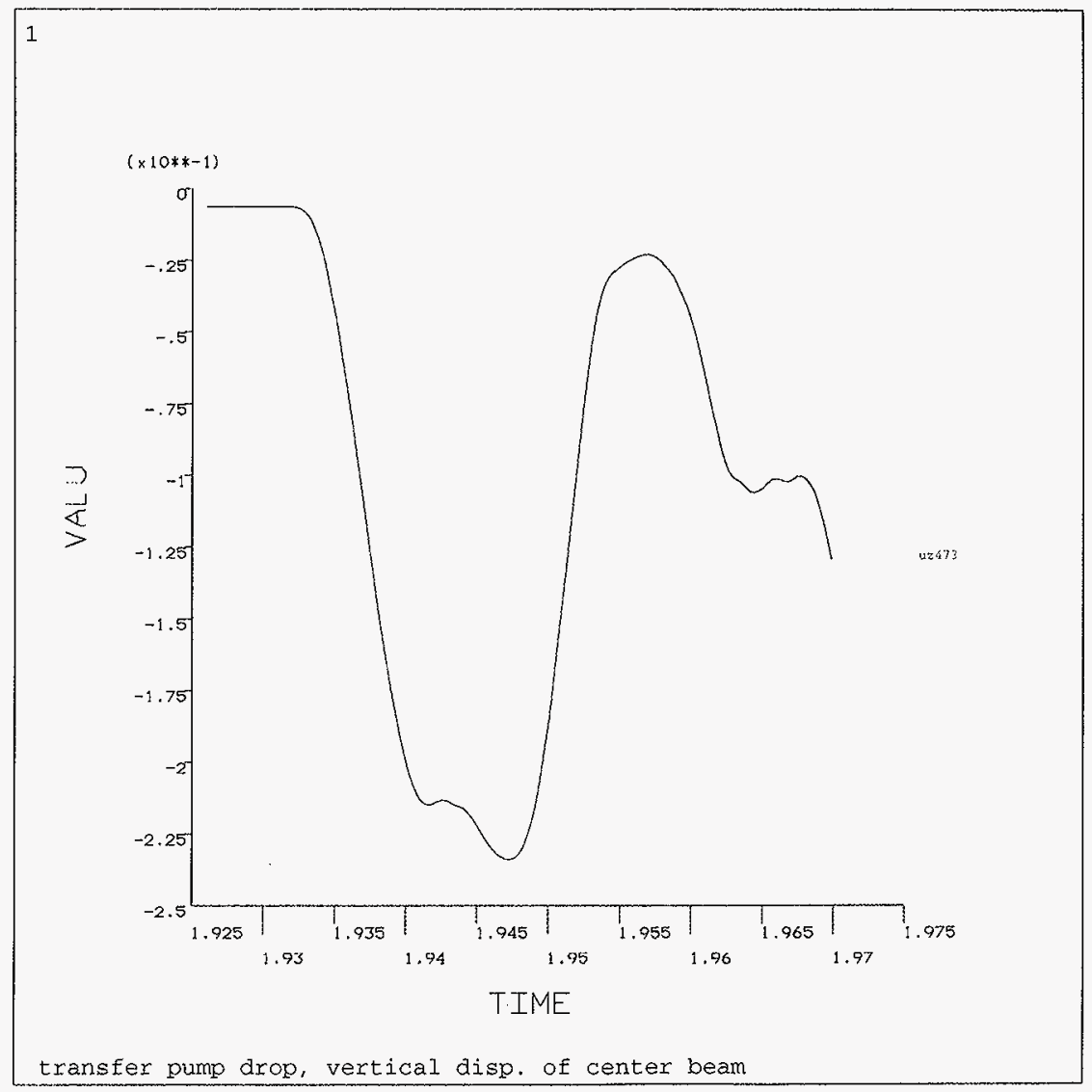

ANSYS 5.2

SEP 81997

$11: 25: 24$

PLOT NO.

POST26

$2 V=1$

DIST $=.75$

$\mathrm{XF}=.5$

$\mathrm{YF}=.5$

$\mathrm{ZF}=.5$

VUP $=\mathrm{Z}$

$Z$-BUFFER 
HNF-SD-TWR-CN-002

Rev. 0 Appendix A

APPENDIX A

MIXER PUMP DROP ANALYSIS

A-1 


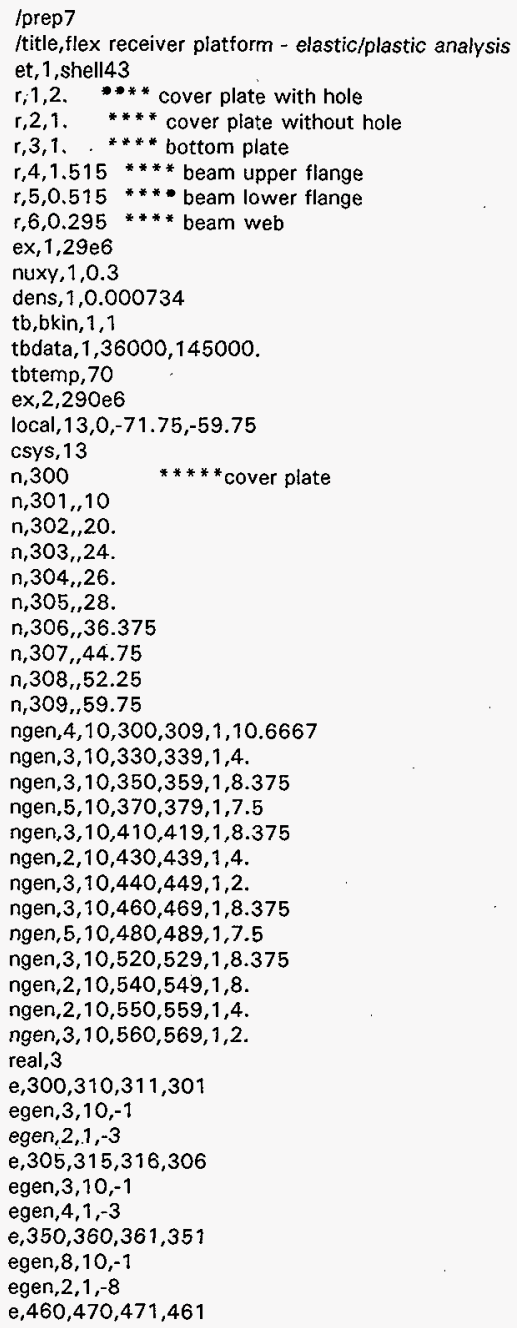


HNF-SD-TWR-CN-002

Rev. 0 Appendix A

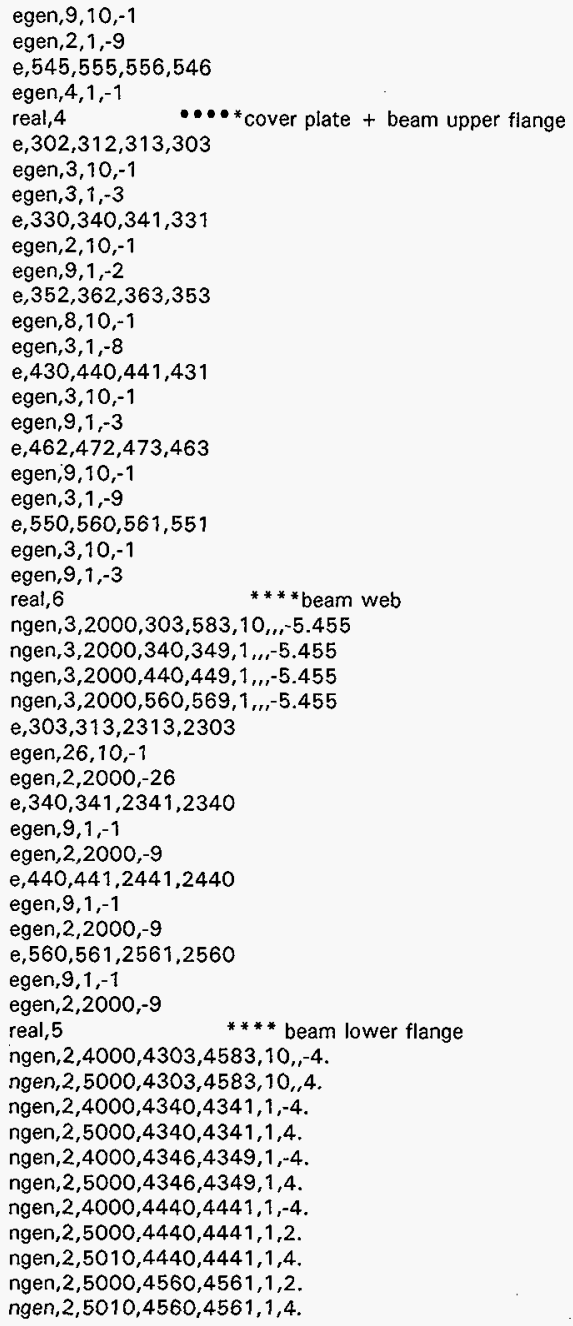


ngen, $2,5000,4446,4449,1,2$. ngen,2,5010,4446,4449,1,4. ngen,2,5000,4566,4569,1,2. ngen, 2,5010,4566,4569,1,4. ngen,2,4000,4446,4449,1,-4. ngen, $2,4000,4560,4561,1,-4$. ngen, $2,4000,4566,4569,1,-4$. e, $4303,4313,8313,8303$ egen, $28,10,-1$ e, $4303,4313,9313,9303$ egen, $28,10,-1$

e, $4340,4341,8341,8340$ $\mathrm{e}, 4340,4341,9341,9340$ $\mathrm{e}, 4341,8343,8333,8341$ e, $4341,8343,8353,9341$ e, $9333,9343,4346,8346$ e, $9343,9353,9346,4346$ $e, 4346,4347,8347,8346$ egen, $3,1,-1$

$e, 4346,4347,9347,9346$ egen, $3,1,-1$

e, $4440,4441,8441,8440$ e, $4440,4441,9441,9440$ e, $9440,9441,9451,9450$ e, $4441,8443,8433,8441$ e. $4441,8443,8453,9441$ e. $9441,8453,8463,9451$ e, $9443,4446,8446,9433$ $e, 9443,4446,9446,9453$ e, $9453,9446,9456,9463$ $\mathrm{e}, 4446,4447,8447,8446$ egen, $3,1,-1$ e,4446,4447,9447,9446 egen, $3,1,-1$ e, $9446,9447,9457,9456$ egen, $3,1,-1$ $\mathrm{e}, 4560,4561,8561,8560$ $e, 4560,4561,9561,9560$ e, $9560,9561,9571,9570$ e, $4561,8563,8553,8561$ e, $4561,8563,8573,9561$ $e, 9561,8573,8583,9571$ e, $9563,4566,8566,9553$ e, $9563,4566,9566,9573$ e, $9573,9566,9576,9583$ e, $4566,4567,8567,8566$ egen, $3,1,-1$ e,4566,4567,9567,9566 egen, $3,1,-1$ e, $9566,9567,9577,9576$ egen, $3,7,-1$ csys, 0 
HNF-SD-TWR-CN-002

Rev. 0

Appendix A

$n, 1,-16,-16$
$n, 9,16,-16$

fill

ngen, $5,9,1,9,1,4$

type, 1

real, 2

e, $1,2,11,10$

egen, $8,1,-1$

egen, $4,9,-8$

csys, 1

$n, 100,25$

$n, 108,25,90$

fill

$n, 116,25,180$

fiil

$n, 117,25,-168.75$

$n, 124,25,-90$

fill

$n, 131,25,-11,25$

fill

$e, 37,116,117,28$

$e, 28,117,118,19$

e, $19,118,119,10$.

e, $10,119,120,1$

e, 1,120,121,2

e, $2,121,122,3$

$e, 3,122,123,4$

$e, 4,123,124,5$

$e, 5,124,125,6$

$e, 6,125,126,7$

$\mathrm{e}, 7,126,127,8$

$e, 8,127,128,9$

$\mathrm{e}, 9,128,129,18$

e, $18,129,130,27$

e, $27,130,131,36$

$\mathrm{e}, 36,131,100,45$

ngen, $3,32,100,131,1,2.5$

e, $116,148,149,117$

egen, $15,1,-1$

e, $131,163,132,100$

egen, $2,32,-16$

e, $180,359,358,181$

$e, 181,358,357,182$

e, $182,357,356,183$

e. $183,356,355,184$

e, $184,355,365,185$

e, $185,365,375,186$

e, $186,375,385,187$

e, $187,385,395,188$

e, $188,395,405,189$

e, $189,405,415,190$

e, $190,415,425,191$ 
HNF-SD-TWR-CN-002

Rev. 0

Appendix. A

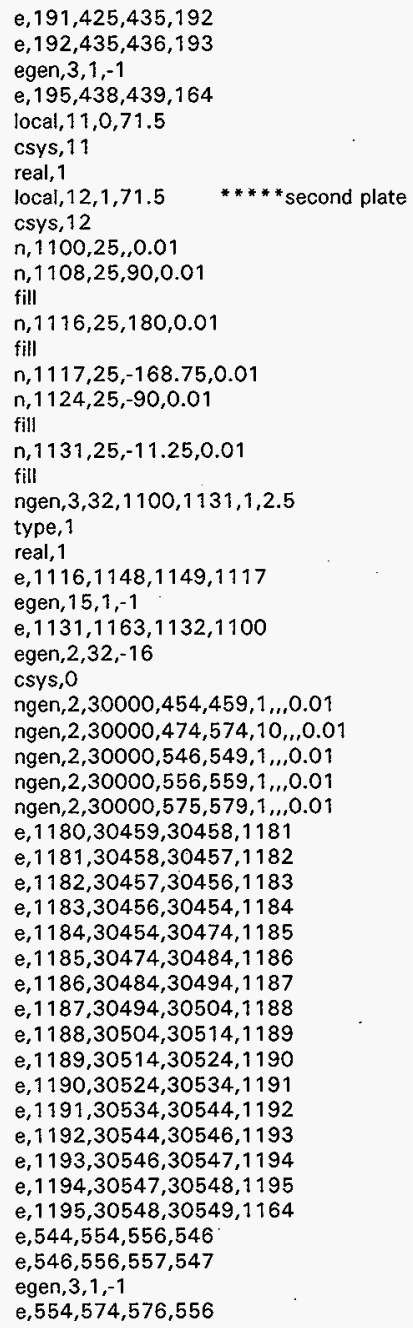


e,556,576,577,557

egen, $3,1,-1$

$\mathrm{cp}, 1, \mathrm{uz}, 457,30457$

$\mathrm{cp}, 2, \mathrm{uz}, 474,30474$

$c p, 3, u z, 494,30494$

$\mathrm{cp}, 4, \mathrm{uz}, 574,30514$

$c p, 5, u z, 534,30534$

$\mathrm{cp}, 6, \mathrm{uz}, 577,30577$

$\mathrm{cp}, 7, \mathrm{ux}, 457,30457$

$\mathrm{cp}, 8, \mathrm{ux}, 474,30474$

cp, $9, \mathrm{ux}, 494,30494$

$\mathrm{cp}, 10, \mathrm{ux}, 514,30514$

$c p, 11, u x, 534,30534$

$c p, 12, u x, 577,30577$

cp, 13,uy, 457,30457

$\mathrm{Cp}_{1} 14, \mathrm{wy}, 474,30474$

cp, 15, uy, 494,30494

$c p, 76, u y, 514,30514$

$c p, 17, \mathrm{y}, 534,30534$

$\mathrm{cp}, 18, \mathrm{uy}, 577,30577$

et, 5 , combin 14,1

$r, 12,10$.

type, 5

real, 12

ngen, $2,6000,4303, \ldots,-01$

$e, 4303,10303$

ngen, $2,6000,4583,, 0.01$

$e, 4583,10583$

et, 6, combin 14,2

$r, 13,10$.

type, 6

real, 13

ngen, $2,6000.4340, \ldots-0.01$

e, 4340,10340

ngen, $2,6000,4440, \ldots,-01$

e, 4440,10440

nsel,s,,,10303

nsel, $a_{,}, 10583$

nsel, a, , 10340

nsel, $a_{r,}, 10440$

d,all,all

alls

csys, 0

ngen, $2,6000,4560,4569,1, \ldots-0.01$

ngen, $2,6000,4303,4340,37, \ldots-0.01$

ngen, $2,6000,4440, \ldots,, 0.01$

et, 2, contac52,...., 1

$r, 11,1.0 \mathrm{e} 8,1$

$r, 20,1.0 e 7,1$

type, 2

real, 11

e, 10560,4560 
HNF-SD-TWR-CN-002

Rev. 0

Appendix A

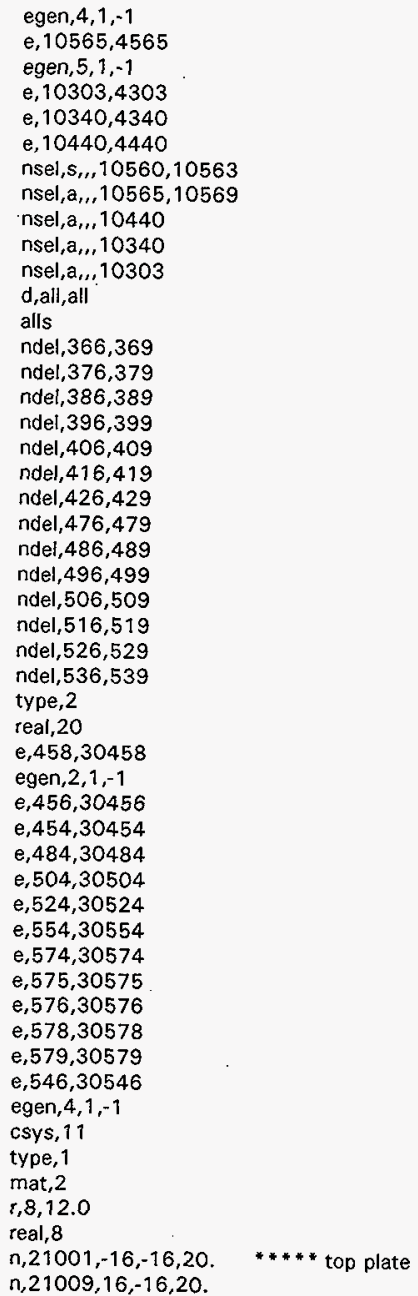


HNF-SD-TWR-CN-002

Rev. 0

Appendix A

ngen, $5,9,21001,21009,1,4$ e,21001,21002,21011,21010 egen, $8,1,-1$

egen, $4,9,-8$

csys, 12

$\mathrm{n}, 21100,25,20$.

$\mathrm{n}, 21108,25,90,20$.

fill

$n, 21116,25,180,20$.

fill

$\mathrm{n}, 21117,25,-168.75,20$.

$\mathrm{n}, 21124,25,-90,20$.

fill

$\mathrm{n}, 21131,25,-11.25,20$.

fill

e,21037,21116,21117,21028

$e, 21028,21117,21118,21019$

e,21019,21118,21119,21010

e,21010,21119,21120,21001

e,21001,21120,21121,21002

e, $21002,21121,21122,21003$

e,21003,21122,21123,21004

$e, 21004,21123,21124,21005$

e,21005,21124,21125,21006

$\mathrm{e}, 21006,21125,21126,21007$

e,21007,21126,21127,21008

e,21008,21127,21128,21009

$\mathrm{e}, 21009,21128,21129,21018$

e, $21018,21129,21130,21027$

$e, 21027,21130,21131,21036$

e,21036,21131,21100,21045 ngen, $3,32,21100,21131,1,2.5$ e,21116,21148,21149,21117

egen, $15,1,-1$

e,21131,21163,21132,21100

egen, $2,32,-16$

et, 3, combin $40, \ldots 3$

$r, 9,50000, \ldots, 10000$

$r, 10,25000, \ldots, 5000$

type, 3

real, 9

e, 7181,21181

egen, $15,1,-1$

real, 10

e, 1180,21180

e, 1164,21164

d, 21188,ux , ,., uy, rotx, roty, rotz

alls

et, 4, combin $40,1,3,2$

$\mathrm{g}=386.4$

$r, 11,100000,(6500 / 9), 720$.

ngen, 2,3000,21041,..,720. 
HNF-SD-TWR-CN-002

Rev. 0

Appendix A

type, 4

real, 11

e,21041,24041

tunif, 70 .

csys, 13

nsel,s,loc, y, 59.74,59.76

dsym,symm, y, 13

alls

save

fini

/solu

antype,trans

kbc, 1

acel, ,. g

d, 24041,uz

timint, off

time, 0.00001

nsubst, 2

neqit, 40

Iswrite

timint,on

time, 1.93

nsubst, 1000

outres, 5

autots, on

ddele,24041,uz

Iswrite

time, 1.99

nsubst, 600

outres, 3

neqit, 40

autots, off

Iswrite

Issolve, 1,3

fini

lexit 
Running ANSYS 5.2 on workstation: cea3 on: Mon Aug 25 11:37:25 PDT 1997

ANSYS 5.2 has been verified by ICF KH

Class 3 Error Reports are in the directory: /apps/ansys/class3_errors.

Executing /apps/ansys/sgi/ansys52/bin/ansys.e52
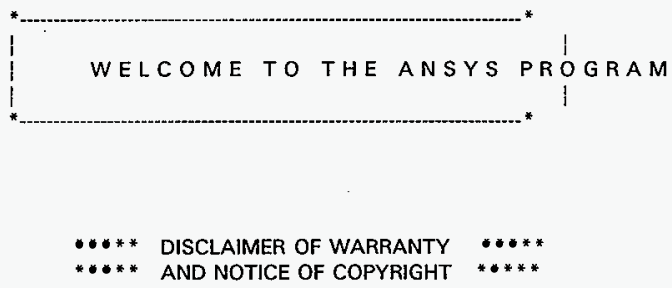

This ANSYS(R) software product (the Program), its Help System (Help System), and program documentation (Documentation) are furnished by ANSYS, Inc. under an ANSYS License Agreement that contains provisions concerning non-disclosure, copying, length and nature of use, warranties, disclaimers and remedies, and other provisions. The Program may be used or copied only in accordance with the terms of that License Agreement. Some of those terms are summarized here.

The Program should only be used by qualified persons. The determination as to who is qualified to use the Program is the obligation of the Licensee under the License Agreement.

NEITHER ANSYS, INC. NOR THE DISTRIBUTOR SUPPLYING THE PROGRAM (THE DISTRIBUTOR) GUARANTEES THE USEFULNESS OF THE RESULTS OF ANY ANALYSIS PERFORMED WITH THIS PROGRAM, ITS HELP SYSTEM, OR DOCUMENTATION. It is the responsibility of the Licensee or user to confirm the usefulness and accuracy of all the solutions.

The Help System and Documentation consist of the ANSYS User's Manual and various other manuals. The User's Manual consists ONLY of the following four volumes: Procedures, Commands, Elements, and Theory. The User's Manual is identified with the words "ANSYS User's Manual" at the bottom of each page.

EXCEPT AS PROVIDED IN THE LICENSE AGREEMENT, NEITHER ANSYS, INC. NOR THE DISTRIBUTOR SHALL BE LIABLE FOR THE NEGLIGENT PREPARATION OF THE PROGRAM, THE HELP SYSTEM, OR USER'S MANUAL; OR FOR ANY TECHNICAL, EDITORIAL, OR OTHER ERRORS OR OMISSIONS WHICH THE HELP SYSTEM OR USER'S MANUAL MIGHT CONTAIN. ANSYS, INC. SHALL NOT BE LIABLE FOR INCIDENTAL, CONSEOUENTIAL, COMPENSATORY OR EXEMPLARY DAMAGES RESULTING FROM ANY SUCH NEGLIGENT PREPARATION OR ERROR. 
EXCEPT AS PROVIDED IN THE LICENSE AGREEMENT, ANSYS, INC. AND THE DISTRIBUTOR HEREBY DISCLAIM ANY EXPRESS OR IMPLIED WARRANTY, INCLUDING BUT NOT LIMITED TO, THE WARRANTY OF MERCHANTABILITY OR FITNESS FOR A PARTICULAR PURPOSE WITH REGARD TO THE PROGRAM OR THE CONTENTS, INFORMATION, AND INSTRUCTIONS CONTAINED IN THE HELP SYSTEM OR USER'S MANUAL, WHETHER SAID WARRANTIES ARISE UNDER PROVISIONS OF ANY LAW OF THE UNITED STATES OF AMERICA OR ANY STATE THEREOF OR ANY OTHER COUNTRY, OR PURSUANT TO THE PROVISIONS OF THE UNITED NATIONS CONVENTION ON CONTRACTS FOR THE INTERNATIONAL SALE OF GOODS.

Examples, solutions, theories, results, methods, and references to other documents are provided in the Help System and User's Manual for guidance and explanation only. THEY ARE NOT GUARANTEED TO PROVIDE THE USER WITH THE MOST ACCURATE, USEFUL, OR CORRECT ANALYSIS FOR ANY PARTICULAR PROBLEM.

The Program, Help System, and Documentation are protected by United States copyright law. You may print pages from the Help System to a printer for your own personal use. You may not further copy or reproduce such pages in any form without the prior written permission of ANSYS, Inc.

ANSYS, Inc. is endeavoring to make the ANSYS program as complete, accurate, and easy to use as possible. Suggestions and comments are welcome. Please bring any errors in either the Documentation or the Program results to the attention of ANSYS, Inc. by contacting your Distributor.

Copyright 1971, 1978, 1982, 1983, 1985, 1987, 1989, 1992, 1993, 1994,1995 by SAS IP as an unpublished work. Proprietary data--unauthorized use, distribution, or duplication, is prohibited. All rights reserved.

\section{*** WARNING ***}

AUTHORIZATION FILE WILL SOON EXPIRE. CONTACT YOUR LOCAL. ANSYS DISTRIBUTOR FOR DETAILS.

AFTER YOU HAVE READ AND UNDERSTOOD THE PREVIOUS DISCLAIMER, PRESS <CR > OR <ENTER > TO CONTINUE

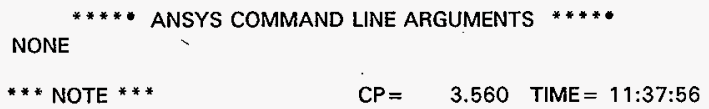

There are no parameters and no abbreviations defined.

32207 VERSION $=$ SGI IRIS $4 D \quad$ REVISION $=5.2$

FOR SUPPORT CALL K MCMillian 373- PHONE JLR 206-353-8089 FAX FAX 509-373-6975

CURRENT JOBNAME $=$ file $11: 37: 56$ AUG $25,1997 \mathrm{CP}=3.570$ 
RUN SETUP PROCEDURE FROM FILE = /apps/ansys/sgi/ansys52/docu/start.ans

/INPUT FILE $=$ /apps/ansys/sgi/ansys52/docu/start.ans $\operatorname{LINE}=0$

BEGIN:

*** ANSYS - ENGINEERING ANALYSIS SYSTEM REVISION 5.2 ***

32207 VERSION $=$ SGI IRIS4D 11:38:09 AUG $25,1997 \mathrm{CP}=3.810$

FOR SUPPORT. CALL K MCMillian 373- PHONE JLR 206-353-8089 FAX FAX 509-373-6975

"**" ANSYS ANALYSIS DEFINITION (PREP7)

ENTER /SHOW,DEVICE-NAME TO ENABLE GRAPHIC DISPLAY

ENTER FINISH TO LEAVE PREP7

PRINTOUT KEY SET TO /GOPR (USE /NOPR TO SUPPRESS)

PREP7:

TITLE $=$

flex receiver platform - elastic/plastic analysis

PREP7:

ELEMENT TYPE 1 IS SHELL43 4-NODE STRUCTURAL SHELL

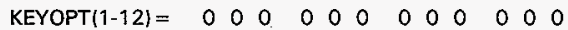

CURRENT NODAL DOF SET IS UX UY UZ ROTX ROTY ROTZ THREE-DIMENSIONAL MODEL

PREP7:

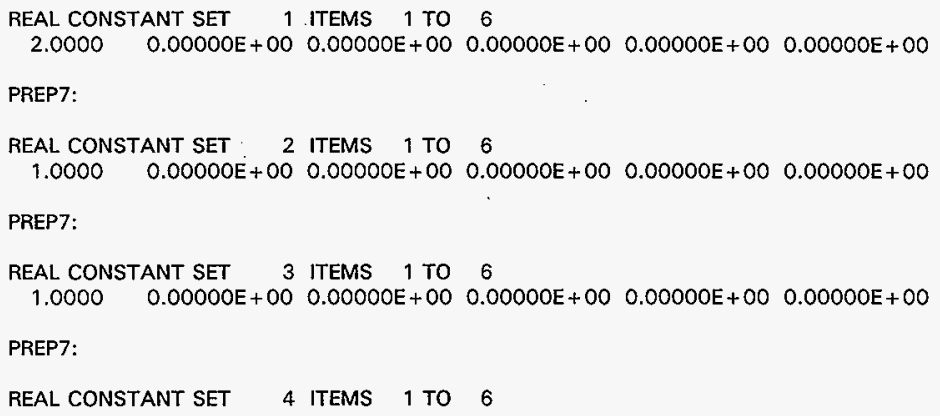


PREP7:

REAL CONSTANT SET 5 ITEMS 1 TO 6

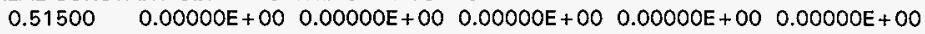

PREP7:

REAL CONSTANT SET 6 ITEMS 1 TO 6

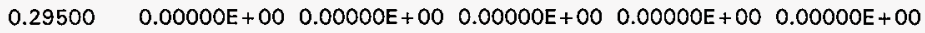

PREP7:

MATERIAL 1 EX $=0.2900000 E+08$

PREP7:

MATERIAL 1 NUXY $=0.3000000$

PREP7:

MATERIAL 1 DENS $=0.7340000 \mathrm{E}-03$

PREP7:

DEFINE DATA TABLE BKIN FOR MATERIAL 1

WITH.A MAXIMUM OF 1 TEMPERATURE SPECIFICATIONS

PREP7:

DATA FOR BKIN TABLE FOR MATERIAL 1 AT TEMPERATURE $=0.00000 E+00$

LOC $=136000 . \quad 0.14500 \mathrm{E}+06$

PREP7:

TEMPERATURE TO BE USED FOR THE NEXT TBDAT COMMAND $=70.000$ TEMPERATURE SPECIFICATION $=1$

PREP7:

MATERIAL 2 EX $=0.2900000 E+09$

PREP7:

COORDINATE SYSTEM 13 DEFINITION. TYPE $=0$ (CARTESIAN) $X C, Y C, Z C=-71.750 \quad-59.750 \quad 0.00000 E+00$

ANGLES $=\quad \begin{array}{lllll}0.00 & 0.00 & 0.00 & \text { PARAMETERS }= & 1.000 \quad 1.000\end{array}$

ORIENTATION $=\begin{array}{lllllllll}1.00 & 0.00 & 0.00 & 0.00 & 1.00 & 0.00 & 0.00 & 0.00 & 1.00\end{array}$

ACTIVE COORDINATE SYSTEM SET TO 13 (CARTESIAN) 
HNF-SD-TWR-CN-002

Rev. 0 Appendix A

PREP7:

\section{ACTIVE COORDINATE SYSTEM SET TO 13 (CARTESIAN)}

PREP7:

NODE $300 \mathrm{KCS}=13 \quad X, Y, Z=0.00000 E+000.00000 E+000.00000 E+00$

PREP7:

NODE $301 \quad K C S=13 \quad X, Y, Z=0.00000 E+00 \quad 10.000 \quad 0.00000 E+00$

PREP7:

NODE $302 \mathrm{KCS}=13 \quad \mathrm{X}, \mathrm{Y}, \mathrm{Z}=0.00000 \mathrm{E}+0020.000 \quad 0.00000 \mathrm{E}+00$

PREP7:

NODE $303 \quad K C S=13 \quad X, Y, Z=0.00000 E+00 \quad 24.000 \quad 0.00000 E+00$

PREP7:

NODE $304 \mathrm{KCS}=13 \quad \mathrm{X}, \mathrm{Y}, \mathrm{Z}=0.00000 \mathrm{E}+00 \quad 26.000 \quad 0.00000 \mathrm{E}+00$

PREP7:

NODE $305 \mathrm{KCS}=13 \quad X, Y, Z=0.00000 E+00 \quad 28.000 \quad 0.00000 E+00$

PREP7:

NODE $306 \mathrm{KCS}=13 \quad X, Y, Z=0.00000 E+00 \quad 36.375 \quad 0.00000 E+00$

PREP7:

NODE $307 \mathrm{KCS}=13 \quad X, Y, Z=0.00000 E+0044.750 \quad 0.00000 E+00$

PREP7:

NODE $308 \quad K C S=13 \quad X, Y, Z=0.00000 E+0052.250 \quad 0.00000 E+00$

PREP7:

NODE $309 \mathrm{KCS}=13 \quad X, Y, Z=0.00000 E+00 \quad 59.750 \quad 0.00000 E+00$

PREP7:

GENERATE 4 TOTAL SETS OF NODES WITH INCREMENT 10 SET IS SELECTED NODES IN RANGE 300 TO 309 IN STEPS OF 1 GEOMETRY INCREMENTS ARE $10.667 \quad 0.00000 E+000.00000 E+00$ SPACING $=1.0000$

PREP7: 
HNF-SD-TWR-CN-002

Rev. 0

Appendix A

GENERATE 3 TOTAL SETS OF NODES WITH INCREMENT 10

SET IS SELECTED NODES IN RANGE 330 TO 339 IN STEPS OF 1

GEOMETRY INCREMENTS ARE $4.0000 \quad 0.00000 E+000.00000 E+00$ SPACING $=1.0000$

PREP7:

GENERATE 3 TOTAL SETS OF NODES WITH INCREMENT 10

SET IS SELECTED NODES IN RANGE 350 TO 359 IN STEPS OF 1

GEOMETRY INCREMENTS ARE $8.3750 \quad 0.00000 E+000.00000 E+00$ SPACING $=1.0000$

PREP7:

GENERATE 5 TOTAL SETS OF NODES WITH INCREMENT 10 SET IS SELECTED NODES IN RANGE 370 TO 379 IN STEPS OF $i$

GEOMETRY INCREMENTS ARE $7.5000 \quad 0.00000 \mathrm{E}+000.00000 \mathrm{E}+00 \mathrm{SPACING}=1.0000$

PREP7:

GENERATE 3 TOTAL SETS OF NODES WITH INCREMENT 10

SET IS SELECTED NODES IN RANGE 410 TO 419 IN STEPS OF 1

GEOMETRY INCREMENTS ARE $8.3750 \quad 0.00000 E+000.00000 E+00$ SPACING $=1.0000$

PREP7:

GENERATE 2 TOTAL SETS OF NODES WITH INCREMENT 10

SET IS SELECTED NODES IN RANGE 430 TO 439 IN STEPS OF 1

GEOMETRY INCREMENTS ARE $4.0000 \quad 0.00000 E+000.00000 E+00$ SPACING $=1.0000$

PREP7:

GENERATE 3 TOTAL SETS OF NODES WITH INCREMENT 10

SET IS SELECTED NODES IN RANGE 440 TO 449 IN STEPS OF 1

GEOMETRY INCREMENTS ARE $2.0000 \quad 0.00000 E+00 \quad 0.00000 E+00$ SPACING $=1.0000$

PREP7:

GENERATE 3 TOTAL SETS OF NODES WITH INCREMENT 10

SET IS SELECTED NODES IN RANGE 460 TO 469 IN STEPS OF 1

GEOMETRY INCREMENTS ARE $8.3750 \quad 0.00000 E+000.00000 E+00$ SPACING $=1.0000$

PREP7:

GENERATE 5 TOTAL SETS OF NODES WITH INCREMENT 10

SET IS SELECTED NODES IN RANGE 480 TO 489 IN STEPS OF 1

GEOMETRY INCREMENTS ARE $7.5000 \quad 0.00000 E+000.00000 E+00$ SPACING $=1.0000$

PREP7:

GENERATE 3 TOTAL SETS OF NODES WITH INCREMENT 10

SET IS SELECTED NODES IN RANGE 520 TO 529 IN STEPS OF 1

GEOMETRY INCREMENTS ARE $8.3750 \quad 0.00000 E+000.00000 E+00$ SPACING $=1.0000$ 
HNF-SD-TWR-CN-002

Rev. 0

Appendix A

PREP7:

GENERATE 2 TOTAL SETS OF NODES WITH INCREMENT 10 SET IS SELECTED NODES IN RANGE 540 TO 549 IN STEPS OF 1 GEOMETRY INCREMENTS ARE $8.0000 \quad 0.00000 \mathrm{E}+00 \quad 0.00000 \mathrm{E}+00$ SPACING $=1.0000$

PREP7:

GENERATE 2 TOTAL SETS OF NODES WITH INCREMENT 10 SET IS SELECTED NODES IN RANGE 550 TO 559 IN STEPS OF 1 GEOMETRY INCREMENTS ARE $4.0000 \quad 0.00000 \mathrm{E}+00 \quad 0.00000 \mathrm{E}+00$ SPACING $=1.0000$

PREP7:

GENERATE 3 TOTAL SETS OF NODES WITH INCREMENT 10

SET IS SELECTED NODES IN RANGE 560 TO 569 iN STEPS OF 1 GEOMETRY INCREMENTS ARE $2.0000 \quad 0.00000 \mathrm{E}+00 \quad 0.00000 \mathrm{E}+00 \mathrm{SPACING}=1.0000$

PREP7:

REAL CONSTANT NUMBER $=3$

PREP7:

$\begin{array}{llllll}\text { ELEMENT } & 1 & 300 & 310 & 311 & 301\end{array}$

PREP7:

GENERATE 3 TOTAL SETS OF ELEMENTS WITH NODE INCREMENT OF 10 SET IS SELECTED ELEMENTS IN RANGE 1 TO 1 IN STEPS OF 1 MAXIMUM ELEMENT NUMBER $=3$

PREP7:

GENERATE 2 TOTAL SETS OF ELEMENTS WITH NODE INCREMENT OF 1 $\begin{array}{llll}\text { SET IS SELECTED ELEMENTS IN RANGE } & 1 \text { TO } 3 \text { IN STEPS OF } & 1\end{array}$ MAXIMUM ELEMENT NUMBER $=6$

PREP7:

$\begin{array}{llllll}\text { ELEMENT } & 7 & 305 & 315 & 316 & 306\end{array}$

PREP7:

GENERATE 3 TOTAL SETS OF ELEMENTS WITH NODE INCREMENT OF 10 SET IS SELECTED ELEMENTS IN RANGE 7 TO 7 IN STEPS OF 1 MAXIMUM ELEMENT NUMBER $=9$

PREP7:

GENERATE 4 TOTAL SETS OF ELEMENTS WITH NODE INCREMENT OF 1 SET IS SELECTED ELEMENTS IN RANGE 7 TO 9 IN STEPS OF 1 
MAXIMUM ELEMENT NUMBER $=18$

PREP7:

$\begin{array}{llllll}\text { ELEMENT } & 19 & 350 & 360 & 361 & 351\end{array}$

PREP7:

GENERATE 8 TOTAL SETS OF ELEMENTS WITH NODE INCREMENT OF 10 SET IS SELECTED ELEMENTS IN RANGE 19 TO 19 IN STEPS OF 1 MAXIMUM ELEMENT NUMBER $=26$

PREP7:

GENERATE 2 TOTAL SETS OF ELEMENTS WITH NODE INCREMENT OF 1 SET IS SELECTED ELEMENTS IN RANGE 19 TO 26 IN STEPS OF 1 MAXIMUM ELEMENT NUMBER $=34$

PREP7:

$\begin{array}{llllll}\text { ELEMENT } & 35 & 460 & 470 & 471 & 461\end{array}$

PREP7:

GENERATE 9 TOTAL SETS OF ELEMENTS WITH NODE INCREMENT OF 10 SET IS SELECTED ELEMENTS IN RANGE 35 TO 35 IN STEPS OF 1 MAXIMUM ELEMENT NUMBER $=43$

PREP7:

GENERATE 2 TOTAL SETS OF ELEMENTS WITH NODE INCREMENT OF 1 SET IS SELECTED ELEMENTS IN RANGE 35 TO 43 IN STEPS OF 1 MAXIMUM ELEMENT NUMBER $=52$

PREP7:

$\begin{array}{llllll}\text { ELEMENT } & 53 & 545 & 555 & 556 & 546\end{array}$

PREP7:

GENERATE 4 TOTAL SETS OF ELEMENTS WITH NODE INCREMENT OF 1 SET IS SELECTED ELEMENTS IN RANGE 53 TO 53 IN STEPS OF 1 MAXIMUM ELEMENT NUMBER $=56$

PREP7:

REAL CONSTANT NUMBER $=4$

PREP7:

$\begin{array}{llllll}\text { ELEMENT } & 57 & 302 & 312 & 313 & 303\end{array}$ 
HNF-SD-TWR-CN-002

Rev. 0

Appendix A

PREP7:

GENERATE 3 TOTAL. SETS OF ELEMENTS WITH NODE INCREMENT OF 10 SET IS SELECTED ELEMENTS IN RANGE 57 TO 57 IN STEPS OF 1 MAXIMUM ELEMENT NUMBER $=\quad 59$

PREP7:

GENERATE 3 TOTAL SETS OF ELEMENTS WITH NODE INCREMENT OF 1 SET IS SELECTED ELEMENTS IN RANGE 57 TO 59 IN STEPS OF 1 MAXIMUM ELEMENT NUMBER $=65$

PREP7:

$\begin{array}{llllll}\text { ELEMENT } & 66 & 330 & 340 & 341 & 331\end{array}$

PREP7:

GENERATE 2 TOTAL SETS OF ELEMENTS WITH NODE INCREMENT OF 10 SET IS SELECTED ELEMENTS IN RANGE 66 TO 66 IN STEPS OF 1 MAXIMUM ELEMENT NUMBER $=67$

PREP7:

GENERATE 9 TOTAL SETS OF ELEMENTS WITH NODE INCREMENT OF 1 SET IS SELECTED ELEMENTS IN RANGE 66 TO 67 IN STEPS OF 1 MAXIMUM ELEMENT NUMBER $=83$

PREP7:

$\begin{array}{llllll}\text { ELEMENT } & 84 & 352 & 362 & 363 & 353\end{array}$

PREP7:

GENERATE 8 TOTAL SETS OF ELEMENTS WITH NODE INCREMENT OF 10 SET IS SELECTED ELEMENTS IN RANGE 84 TO 84 IN STEPS OF 1 MAXIMUM ELEMENT NUMBER $=91$

PREP7:

GENERATE 3 TOTAL SETS OF ELEMENTS WITH NODE INCREMENT OF 1 SET IS SELECTED ELEMENTS IN RANGE 84 TO 91 IN STEPS OF 1 MAXIMUM ELEMENT NUMBER $=107$

PREP7:

$\begin{array}{llllll}\text { ELEMENT } & 108 & 430 & 440 & 441 & 431\end{array}$

PREP7:

GENERATE 3 TOTAL SETS OF ELEMENTS WITH NODE INCREMENT OF 10 SET IS SELECTED ELEMENTS IN RANGE 108 TO 108 IN STEPS OF 1 
HNF-SD-TWR-CN-002

Rev. 0 Appendix A

MAXIMUM ELEMENT NUMBER $=110$

PREP7:

GENERATE 9 TOTAL SETS OF ELEMENTS WITH NODE INCREMENT OF 1

SET IS SELECTED ELEMENTS IN RANGE 108 TO 110 IN STEPS OF 1

MAXIMUM ELEMENT NUMBER $=134$

PREP7:

ELEMENT $\quad 135 \quad 462 \quad 472 \quad 473 \quad 463$

PREP7:

GENERATE 9 TOTAL SETS OF ELEMENTS WITH NODE INCREMENT OF 10 SET IS SELECTED ELEMENTS IN RANGE 135 TO 135 IN STEPS OF 1 MAXIMUM ELEMENT NUMBER $=143$

PREP7:

GENERATE 3 TOTAL SETS OF ELEMENTS WITH NODE INCREMENT OF 1 SET IS SELECTED ELEMENTS IN RANGE 135 TO 143 IN STEPS OF 1 MAXIMUM ELEMENT NUMBER $=161$

PREP7:

ELEMENT $\quad 162 \quad 550 \quad 560 \quad 561 \quad 551$

PREP7:

GENERATE 3 TOTAL SETS OF ELEMENTS WITH NODE INCREMENT OF 10 SET IS SELECTED ELEMENTS IN RANGE 162 TO 162 IN STEPS OF 1 MAXIMUM ELEMENT NUMBER $=164$

PREP7:

GENERATE 9 TOTAL SETS OF ELEMENTS WITH NODE INCREMENT OF 1 SET IS SELECTED ELEMENTS IN RANGE 162 TO 164 IN STEPS OF 1 MAXIMUM ELEMENT NUMBER $=188$

PREP7:

REAL CONSTANT NUMBER $=6$

PREP7:

GENERATE 3 TOTAL SETS OF NODES WITH INCREMENT 2000 SET IS SELECTED NODES IN RANGE 303 TO 583 IN STEPS OF 10 GEOMETRY INCREMENTS ARE $0.00000 E+000.00000 E+00-5.4550 \quad$ SPACING $=1.0000$

PREP7: 
GENERATE 3 TOTAL SETS OF NODES WITH INCREMENT 2000

SET IS SELECTED NODES IN RANGE 340 TO 349 IN STEPS OF 1

GEOMETRY INCREMENTS ARE $0.00000 E+000.00000 E+00-5.4550 \quad$ SPACING $=1.0000$

PREP7:

GENERATE 3 TOTAL SETS OF NODES WITH INCREMENT 2000

SET IS SELECTED NODES IN RANGE 440 TO 449 IN STEPS OF 1

GEOMETRY INCREMENTS ARE $0.00000 E+000.00000 E+00-5.4550 \quad$ SPACING $=1.0000$

PREP7:

GENERATE 3 TOTAL SETS OF NODES WITH INCREMENT 2000

SET IS SELECTED NODES IN RANGE 560 TO 569 IN STEPS OF 1

GEOMETRY INCREMENTS ARE $0.00000 E+000.00000 E+00-5.4550 \quad$ SPACING $=1.0000$

PREP7:

$\begin{array}{llllll}\text { ELEMENT } & 189 & 303 & 313 & 2313 & 2303\end{array}$

PREP7:

GENERATE 26 TOTAL SETS OF ELEMENTS WITH NODE INCREMENT OF 10 SET IS SELECTED ELEMENTS IN RANGE 189 TO 189 IN STEPS OF 1 MAXIMUM ELEMENT NUMBER $=214$

PREP7:

GENERATE 2 TOTAL SETS OF ELEMENTS WITH NODE INCREMENT OF 2000 SET IS SELECTED ELEMENTS IN RANGE 189 TO 214 IN STEPS OF 1 MAXIMUM ELEMENT NUMBER $=240$

PREP7:

$\begin{array}{llllll}\text { ELEMENT } & 241 & 340 & 341 & 2341 & 2340\end{array}$

PREP7:

GENERATE 9 TOTAL SETS OF ELEMENTS WITH NODE INCREMENT OF 1 SET IS SELECTED ELEMENTS IN RANGE 241 TO 241 IN STEPS OF 1 MAXIMUM ELEMENT NUMBER $=249^{\circ}$

PREP7:

GENERATE 2 TOTAL SETS OF ELEMENTS WITH NODE INCREMENT OF 2000 SET IS SELECTED ELEMENTS IN RANGE 241 TO 249 IN STEPS OF 1 MAXIMUM ELEMENT NUMBER $=258$

PREP7:

$\begin{array}{llllll}\text { ELEMENT } & 259 & 440 & 441 & 2441 & 2440\end{array}$ 


\section{HNF-SD-TWR-CN-002 \\ Rev. 0 \\ Appendix A}

PREP7:

GENERATE 9 TOTAL SETS OF ELEMENTS WITH NODE INCREMENT OF 1 SET IS SELECTED ELEMENTS IN RANGE 259 TO 259 IN STEPS OF 1 MAXIMUM ELEMENT NUMBER $=267$

PREP7:

GENERATE 2 TOTAL SETS OF ELEMENTS WITH NODE INCREMENT OF 2000 SET IS SELECTED ELEMENTS IN RANGE 259 TO 267 IN STEPS OF 1 MAXIMUM ELEMENT NUMBER $=276$

PREP7:

$\begin{array}{llllll}\text { ELEMENT } & 277 & 560 & 561 & 2561 & 2560\end{array}$

PREP7:

GENERATE 9 TOTAL. SETS OF ELEMENTS WITH NODE INCREMENT OF 1 SET IS SELECTED ELEMENTS IN RANGE 277 TO 277 IN STEPS OF 1 MAXIMUM ELEMENT NUMBER $=285$

PREP7:

GENERATE 2 TOTAL SETS OF ELEMENTS WITH NODE INCREMENT OF 2000 SET IS SELECTED ELEMENTS IN RANGE 277 TO 285 IN STEPS OF 1 MAXIMUM ELEMENT NUMBER $=294$

PREP7:

REAL CONSTANT NUMBER $=5$

PREP7:

GENERATE 2 TOTAL SETS OF NODES WITH INCREMENT 4000 SET IS SELECTED NODES IN RANGE 4303 TO 4583 IN STEPS OF 10 GEOMETRY INCREMENTS ARE $0.00000 \mathrm{E}+00-4.0000 \quad 0.00000 \mathrm{E}+00 \mathrm{SPACING}=1.0000$

PREP7:

GENERATE 2 TOTAL SETS OF NODES WITH INCREMENT 5000 SET IS SELECTED NODES IN RANGE 4303 TO 4583 IN STEPS OF 10 GEOMETRY INCREMENTS ARE $0.00000 E+00 \quad 4.0000 \quad 0.00000 E+00$ SPACING $=1.0000$

PREP7:

GENERATE 2 TOTAL SETS OF NODES WITH INCREMENT 4000 SET IS SELECTED NODES IN RANGE 4340 TO $434 \uparrow$ IN STEPS OF 1 GEOMETRY INCREMENTS ARE $-4.0000 \quad 0.00000 E+000.00000 E+00$ SPACING $=1.0000$

PREP7: 
GENERATE 2 TOTAL. SETS OF NODES WITH INCREMENT 5000

SET IS SELECTED NODES IN RANGE 4340 TO 4341 IN STEPS OF 1 GEOMETRY INCREMENTS ARE $4.0000 \quad 0.00000 E+000.00000 E+00$ SPACING $=1.0000$

PREP7:

GENERATE 2 TOTAL SETS OF NODES WITH INCREMENT 4000 SET IS SELECTED NODES IN RANGE 4346 TO 4349 IN STEPS OF 1 GEOMETRY INCREMENTS ARE $-4.0000 \quad 0.00000 \mathrm{E}+000.00000 \mathrm{E}+00 \mathrm{SPACING}=1.0000$

PREP7:

GENERATE 2 TOTAL SETS OF NODES WITH INCREMENT 5000 SET IS SELECTED NODES IN RANGE 4346 TO 4349 IN STEPS OF 1 GEOMETRY INCREMENTS ARE $4.0000 \quad 0.00000 E+00 \quad 0.00000 E+00$ SPACING $=1.0000$

PREP7:

GENERATE 2 TOTAL SETS OF NODES WITH INCREMENT 4000 SET IS SELECTED NODES IN RANGE 4440 TO 4441 IN STEPS OF 1 GEOMETRY INCREMENTS ARE $-4.0000 \quad 0.00000 \mathrm{E}+000.00000 \mathrm{E}+00 \mathrm{SPACING}=1.0000$

PREP7:

GENERATE 2 TOTAL SETS OF NODES WITH INCREMENT 5000 SET IS SELECTED NODES IN RANGE 4440 TO 4441 IN STEPS OF 1 GEOMETRY INCREMENTS ARE $2.0000 \quad 0.00000 \mathrm{E}+000.00000 \mathrm{E}+00$ SPACING $=1.0000$

PREP7:

GENERATE 2 TOTAL SETS OF NODES WITH INCREMENT 5010 SET IS SELECTED NODES IN RANGE 4440 TO 4441 IN STEPS OF 1 GEOMETRY INCREMENTS ARE $4.0000 \quad 0.00000 E+000.00000 E+00$ SPACING $=1.0000$ PREP7:

GENERATE 2 TOTAL SETS OF NODES WITH INCREMENT 5000 SET IS SELECTED NODES IN RANGE 4560 TO 4561 IN STEPS OF 1 GEOMETRY INCREMENTS ARE $2.0000 \quad 0.00000 E+00 \quad 0.00000 E+00$ SPACING $=1.0000$

PREP7:

GENERATE 2 TOTAL SETS OF NODES WITH INCREMENT 5010 SET IS SELECTED NODES IN RANGE 4560 TO 4561 IN STEPS OF 1 GEOMETRY INCREMENTS ARE $4.0000 \quad 0.00000 E+00 \quad 0.00000 E+00$ SPACING $=1.0000$

PREP7:

GENERATE 2 TOTAL SETS OF NODES WITH INCREMENT 5000 SET IS SELECTED NODES IN RANGE 4446 TO 4449 IN STEPS OF 1 GEOMETRY INCREMENTS ARE $2.0000 \quad 0.00000 \mathrm{E}+000.00000 \mathrm{E}+00$ SPACING $=1.0000$ 
PREP7:

GENERATE 2 TOTAL SETS OF NODES WITH INCREMENT 5010

SET IS SELECTED NODES IN RANGE 4446 TO 4449 IN STEPS OF 1

GEOMETRY INCREMENTS ARE $4.0000 \quad 0.00000 E+000.00000 E+00$ SPACING $=1.0000$

PREP7:

GENERATE 2 TOTAL SETS OF NODES WITH INCREMENT 5000

SET IS SELECTED NODES IN RANGE 4566 TO 4569 IN STEPS OF 1

GEOMETRY INCREMENTS ARE $2.0000 \quad 0.00000 E+000.00000 E+00$ SPACING $=1.0000$

PREP7:

GENERATE 2 TOTAL SETS OF NODES. WITH INCREMENT 5010

SET IS SELECTED NODES IN RANGE 4566 TO 4569 IN STEPS OF 1

GEOMETRY INCREMENTS ARE $4.0000 \quad 0.00000 E+000.00000 E+00$ SPACING $=1.0000$

PREP7:

GENERATE 2 TOTAL SETS OF NODES WITH INCREMENT 4000 SET IS SELECTED NODES IN RANGE 4446 TO 4449 IN STEPS OF 1 GEOMETRY INCREMENTS ARE $-4.0000 \quad 0.00000 E+000.00000 E+00$ SPACING $=1.0000$

PREP7:

GENERATE 2 TOTAL. SETS OF NODES WITH INCREMENT 4000

SET IS SELECTED NODES IN RANGE 4560 TO 4561 IN STEPS OF 1

GEOMETRY INCREMENTS ARE $-4.0000 \quad 0.00000 E+000.00000 E+00$ SPACING $=1.0000$

PREP7:

GENERATE 2 TOTAL SETS OF NODES WITH INCREMENT 4000

SET IS SELECTED NODES IN RANGE 4566 TO 4569 IN STEPS OF 1

GEOMETRY INCREMENTS ARE $-4.0000 \quad 0.00000 E+000.00000 E+00$ SPACING $=1.0000$

PREP7:

ELEMENT $\quad 295 \quad 4303 \quad 4313 \quad 8313 \quad 8303$

PREP7:

GENERATE 28 TOTAL SETS OF ELEMENTS WITH NODE INCREMENT OF 10

SET IS SELECTED ELEMENTS IN RANGE 295 TO 295 IN STEPS OF 1

MAXIMUM ELEMENT NUMBER $=322$

PREP7:

ELEMENT $\quad 323 \quad 4303 \quad 4313 \quad 9313 \quad 9303$

PREP7: 
HNF-SD-TWR-CN-002

Rev. 0

Appendix A

GENERATE 28 TOTAL SETS OF ELEMENTS WITH NODE INCREMENT OF 10 SET IS SELECTED ELEMENTS IN RANGE 323 TO 323 IN STEPS OF 1 MAXIMUM ELEMENT NUMBER $=350$

PREP7:

$\begin{array}{llllll}\text { ELEMENT } & 351 & 4340 & 4341 & 8341 & 8340\end{array}$

PREP7:

ELEMENT $\quad 352 \quad 4340 \quad 4341 \quad 9341 \quad 9340$

PREP7:

$\begin{array}{lllllll}\text { ELEMENT } & 353 & 4341 & 8343 & 8333 & 8341\end{array}$

PREP7:

$\begin{array}{llllll}\text { ELEMENT } & 354 & 4341 & 8343 & 8353 & 9341\end{array}$

PREP7:

ELEMENT $\quad 355 \quad 9333 \quad 9343 \quad 4346 \quad 8346$

PREP7:

ELEMENT $\quad 356 \quad 9343 \quad 9353 \quad 9346 \quad 4346$

PREP7:

$\begin{array}{llllll}\text { ELEMENT } & 357 & 4346 & 4347 & 8347 & 8346\end{array}$

PREP7:

GENERATE 3 TOTAL SETS OF ELEMENTS WITH NODE INCREMENT OF 1 SET IS SELECTED ELEMENTS IN RANGE 357 TO 357 IN STEPS OF 1 MAXIMUM ELEMENT NUMBER $=359$

PREP7:

ELEMENT $\quad 360 \quad 4346 \quad 4347 \quad 9347 \quad 9346$

PREP7:

GENERATE 3 TOTAL SETS OF ELEMENTS WITH NODE INCREMENT OF 1 SET IS SELECTED ELEMENTS IN RANGE 360 TO 360 IN STEPS OF 1 MAXIMUM ELEMENT NUMBER $=362$

PREP7:

ELEMENT $\quad 363 \quad 4440 \quad 4441 \quad 8441 \quad 8440$ 
PREP7:

ELEMENT $\quad 364 \quad 4440 \quad 4441 \quad 9441 \quad 9440$

PREP7:

ELEMENT $\quad 365 \quad 9440 \quad 9441 \quad 9451 \quad 9450$

PREP7:

$\begin{array}{llllll}\text { ELEMENT } & 366 & 4441 & 8443 & 8433 & 8441\end{array}$

PREP7:

$\begin{array}{llllll}\text { ELEMENT } & 367 & 4441 & 8443 & 8453 & 9441\end{array}$

PREP7:

$\begin{array}{llllll}\text { ELEMENT } & 368 & 9441 & 8453 & 8463 & 9451\end{array}$

PREP7:

$\begin{array}{lllllll}\text { ELEMENT } & 369 & 9443 & 4446 & 8446 & 9433\end{array}$

PREP7:

$\begin{array}{llllll}\text { ELEMENT } & 370 & 9443 & 4446 & 9446 & 9453\end{array}$

PREP7:

$\begin{array}{llllll}\text { ELEMENT } & 371 & 9453 & 9446 & 9456 & 9463\end{array}$

PREP7:

$\begin{array}{lllllll}\text { ELEMENT } & 372 & 4446 & 4447 & 8447 & 8446\end{array}$

PREP7:

GENERATE 3 TOTAL SETS OF ELEMENTS WITH NODE INCREMENT OF 1 SET IS SELECTED ELEMENTS IN RANGE 372 TO 372 IN STEPS OF 1 MAXIMUM ELEMENT NUMBER $=374$

PREP7:

$\begin{array}{llllll}\text { ELEMENT } & 375 & 4446 & 4447 & 9447 & 9446\end{array}$

PREP7:

GENERATE 3 TOTAL SETS OF ELEMENTS WITH NODE INCREMENT OF 1 SET IS SELECTED ELEMENTS IN RANGE 375 TO 375 IN STEPS OF 1 MAXIMUM ELEMENT NUMBER $=377$ 
PREP7:

$\begin{array}{llllll}\text { ELEMENT } & 378 & 9446 & 9447 & 9457 & 9456\end{array}$

PREP7:

GENERATE 3 TOTAL SETS OF ELEMENTS WITH NODE INCREMENT OF 1 SET IS SELECTED ELEMENTS IN RANGE 378 TO 378 IN STEPS OF 1 MAXIMUM ELEMENT NUMBER $=380$

PREP7:

$\begin{array}{llllll}\text { ELEMENT } & 381 & 4560 & 4561 & 8561 & 8560\end{array}$

PREP7:

ELEMENT $\quad 382 \quad 4560 \quad 4561 \quad 95619560$

PREP7:

$\begin{array}{llllll}\text { ELEMENT } & 383 & 9560 & 9561 & 9571 & 9570\end{array}$

PREP7:

$\begin{array}{llllll}\text { ELEMENT } & 384 & 4561 & 8563 & 8553 & 8561\end{array}$

PREP7:

$\begin{array}{llllll}\text { ELEMENT } & 385 & 4561 & 8563 & 8573 & 9561\end{array}$

PREP7:

$\begin{array}{llllll}\text { ELEMENT } & 386 & 9561 & 8573 & 8583 & 9571\end{array}$

PREP7:

$\begin{array}{llllll}\text { ELEMENT } & 387 & 9563 & 4566 & 8566 & 9553\end{array}$

PREP7:

ELEMENT $388 \quad 9563 \quad 4566 \quad 9566 \quad 9573$

PREP7:

ELEMENT $\quad 389 \quad 9573 \quad 9566 \quad 9576 \quad 9583$

PREP7:

$\begin{array}{llllll}\text { ELEMENT } & 390 & 4566 & 4567 & 8567 & 8566\end{array}$

PREP7: 
HNF-SD-TWR-CN-002

Rev. 0

Appendix A

GENERATE 3 TOTAL. SETS OF ELEMENTS WITH NODE INCREMENT OF 1

SET IS SELECTED ELEMENTS IN RANGE 390 TO 390 IN STEPS OF 1

MAXIMUM ELEMENT NUMBER $=392$

PREP7:

ELEMENT $\quad 393 \quad 4566 \quad 4567 \quad 9567 \quad 9566$

PREP7:

GENERATE 3 TOTAL SETS OF ELEMENTS WITH NODE INCREMENT OF 1 SET IS SELECTED ELEMENTS IN RANGE 393 TO 393 IN STEPS OF 1 MAXIMUM ELEMENT NUMBER $=395$

PREP7:

ELEMENT $\quad 396 \quad 9566 \quad 9567 \quad 9577 \quad 9576$

PREP7:

GENERATE 3 TOTAL SETS OF ELEMENTS WITH NODE INCREMENT OF 1 SET IS SELECTED ELEMENTS IN RANGE 396 TO $396 \mathrm{IN}$ STEPS OF 1 MAXIMUM ELEMENT NUMBER $=398$

PREP7:

ACTIVE COORDINATE SYSTEM SET TO 0 (CARTESIAN)

PREP7:

NODE $1 \mathrm{KCS}=0 \quad X, Y, Z=-16.000 \quad-16.000 \quad 0.00000 E+00$

PREP7:

NODE $9 \mathrm{KCS}=0 \quad \mathrm{X}, \mathrm{Y}, \mathrm{Z}=16.000 \quad-16.000 \quad 0.00000 \mathrm{E}+00$

PREP7:

FILL 7-POINTS BETWEEN NODE 1 AND NODE 9 START WITH NODE 2 AND INCREMENT BY 1

PREP7:

GENERATE 5 TOTAL SETS OF NODES WITH INCREMENT 9 SET IS SELECTED NODES IN RANGE 1 TO 9 IN STEPS OF 1 GEOMETRY INCREMENTS ARE $0.00000 E+00 \quad 4.0000 \quad 0.00000 E+00$ SPACING $=1.0000$

PREP7:

ELEMENT TYPE SET TO 1

PREP7: 
REAL CONSTANT NUMBER $=2$

PREP7:

$\begin{array}{llllll}\text { ELEMENT } & 399 & 1 & 2 & 11 & 10\end{array}$

PREP7:

GENERATE 8 TOTAL SETS OF ELEMENTS WITH NODE INCREMENT OF 1 SET IS SELECTED ELEMENTS IN RANGE 399 TO 399 IN STEPS OF 1 MAXIMUM ELEMENT NUMBER $=406$

PREP7:

GENERATE 4 TOTAL. SETS OF ELEMENTS WITH NODE INCREMENT OF 9 SET IS SELECTED ELEMENTS IN RANGE 399 TO 406 IN STEPS OF 1 MAXIMUM ELEMENT NUMBER $=430$

PREP7:

ACTIVE COORDINATE SYSTEM SET TO 1 (CYLINDRICAL)

PREP7:

NODE $100 \mathrm{KCS}=1 \mathrm{X}, \mathrm{Y}, Z=25.000 \quad 0.00000 \mathrm{E}+000.00000 \mathrm{E}+00$

PREP7:

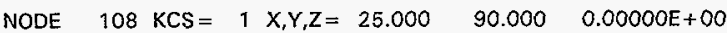

PREP7:

FILL 7 POINTS BETWEEN NODE 100 AND NODE 108 START WITH NODE 101 AND INCREMENT BY 1

PREP7:

NODE $116 \mathrm{KCS}=1 \mathrm{X}, \mathrm{Y}, \mathrm{Z}=25.000 \quad 180.00 \quad 0.00000 \mathrm{E}+00$

PREP7:

FILL 7 POINTS BETWEEN NODE 108 AND NODE 116 START WITH NODE 109 AND INCREMENT BY 1

PREP7:

NODE $117 \mathrm{KCS}=1 \mathrm{X}, \mathrm{Y}, \mathrm{Z}=25.000 \quad-168.75 \quad 0.00000 \mathrm{E}+00$

PREP7:

NODE $124 \mathrm{KCS}=1 \mathrm{X}, Y, Z=25.000 \quad-90.000 \quad 0.00000 \mathrm{E}+\infty$ 
HNF-SD-TWR-CN-002

Rev. 0 Appendix A

PREP7:

FILL 6 POINTS BETWEEN NODE 117 AND NODE 124

START WITH NODE 118 AND INCREMENT BY 1

PREP7:

NODE $131 \mathrm{KCS}=1 \quad \mathrm{X}, Y, Z=25.000 \quad-11.250 \quad 0.00000 \mathrm{E}+00$

PREP7:

FILL 6 POINTS BETWEEN NODE 124 AND NODE 131

START WITH NODE 125 AND INCREMENT BY 1

PREP7:

$\begin{array}{llllll}\text { ELEMENT } & 431 & 37 & 116 & 117 & 28\end{array}$

PREP7:

$\begin{array}{llllll}\text { ELEMENT } & 432 & 28 & 117 & 118 & 19\end{array}$

PREP7:

$\begin{array}{llllll}\text { ELEMENT } & 433 & 19 & 118 & 119 & 10\end{array}$

PREP7:

$\begin{array}{llllll}\text { ELEMENT } & 434 & 10 & 119 & 120 & 1\end{array}$

PREP7:

$\begin{array}{llllll}\text { ELEMENT } & 435 & 1 & 120 & 121 & 2\end{array}$

PREP7:

$\begin{array}{llllll}\text { ELEMENT } & 436 & 2 & 121 & 122 & 3\end{array}$

PREP7:

$\begin{array}{llllll}\text { ELEMENT } & 437 & 3 & 122 & 123 & 4\end{array}$

PREP7:

$\begin{array}{llllll}\text { ELEMENT } & 438 & 4 & 123 & 124 & 5\end{array}$

PREP7:

$\begin{array}{llllll}\text { ELEMENT } & 439 & 5 & 124 & 125 & 6\end{array}$

PREP7: 
HNF-SD-TWR-CN-002

Rev. 0

Appendix A

$\begin{array}{llllll}\text { ELEMENT } & 440 & 6 & 125 & 126 & 7\end{array}$

PREP7:

$\begin{array}{llllll}\text { ELEMENT } & 441 & 7 & 126 & 127 & 8\end{array}$

PREP7:

$\begin{array}{llllll}\text { ELEMENT } & 442 & 8 & 127 & 128 & 9\end{array}$

PREP7:

$\begin{array}{llllll}\text { ELEMENT } & 443 & 9 & 128 & 129 & 18\end{array}$

PREP7:

$\begin{array}{llllll}\text { ELEMENT } & 444 & 18 & 129 & 130 & 27\end{array}$

PREP7:

$\begin{array}{llllll}\text { ELEMENT } & 445 & 27 & 130 & 131 & 36\end{array}$

PREP7:

$\begin{array}{llllll}\text { ELEMENT } & 446 & 36 & 131 & 100 & 45\end{array}$

PREP7:

GENERATE 3 TOTAL SETS OF NODES WITH INCREMENT 32

SET IS SELECTED NODES IN RANGE 100 TO $131 \mathrm{IN}$ STEPS OF 1

GEOMETRY INCREMENTS ARE $2.5000 \quad 0.00000 E+00 \quad 0.00000 E+00$ SPACING $=1.0000$

PREP7:

$\begin{array}{llllll}\text { ELEMENT } & 447 & .116 & 148 & 149 & 117\end{array}$

PREP7:

GENERATE 15 TOTAL SETS OF ELEMENTS WITH NODE INCREMENT OF 1 SET IS SELECTED ELEMENTS IN RANGE 447 TO 447 IN STEPS OF 1 MAXIMUM ELEMENT NUMBER $=461$

PREP7:

$\begin{array}{llllll}\text { ELEMENT } & 462 & 131 & 163 & 132 & 100\end{array}$

PREP7:

GENERATE 2 TOTAL SETS OF ELEMENTS WITH NODE INCREMENT OF 32

SET IS SELECTED ELEMENTS IN RANGE 447 TO 462 IN STEPS OF 1 MAXIMUM ELEMENT NUMBER $=478$ 
PREP7:

$\begin{array}{llllll}\text { ELEMENT } & 479 & 180 & 359 & 358 & 181\end{array}$

PREP7:

$\begin{array}{llllll}\text { ELEMENT } & 480 & 181 & 358 & 357 & 182\end{array}$

PREP7:

$\begin{array}{llllll}\text { ELEMENT } & 481 & 182 & 357 & 356 & 183\end{array}$

PREP7:

$\begin{array}{llllll}\text { ELEMENT } & 482 & 183 & 356 & 355 & 184\end{array}$

PREP7:

$\begin{array}{llllll}\text { ELEMENT } & 483 & 184 & 355 & 365 & 185\end{array}$

PREP7:

$\begin{array}{llllll}\text { ELEMENT } & 484 & 185 & 365 & 375 & 186\end{array}$

PREP7:

$\begin{array}{llllll}\text { ELEMENT } & 485 & 186 & 375 & 385 & 187\end{array}$

PREP7:

$\begin{array}{llllll}\text { ELEMENT } & 486 & 187 & 385 & 395 & 188\end{array}$

PREP7:

$\begin{array}{llllll}\text { ELEMENT } & 487 & 188 & 395 & 405 & 189\end{array}$

PREP7:

$\begin{array}{llllll}\text { ELEMENT } & 488 & 189 & 405 & 415 & 190\end{array}$

PREP7:

$\begin{array}{llllll}\text { ELEMENT } & 489 & 190 & 415 & 425 & 191\end{array}$

PREP7:

$\begin{array}{llllll}\text { ELEMENT } & 490 & 191 & 425 & 435 & 192\end{array}$

PREP7:

$\begin{array}{llllll}\text { ELEMENT } & 491 & 192 & 435 & 436 & 193\end{array}$ 
PREP7:

GENERATE 3 TOTAL SETS OF ELEMENTS WITH NODE INCREMENT OF 1 SET IS SELECTED ELEMENTS IN RANGE 491 TO 491 IN STEPS OF 1 MAXIMUM ELEMENT NUMBER $=493$

PREP7:

$\begin{array}{llllll}\text { ELEMENT } & 494 & 195 & 438 & 439 & 164\end{array}$

PREP7:

COORDINATE SYSTEM 11 DEFINITION. TYPE $=0$ (CARTESIAN)

$X C, Y C, Z C=71.500 \quad 0.00000 E+000.00000 E+00$

ANGLES $=0.00 \quad 0.00 \quad 0.00$ PARAMETERS $=1.000 \quad 1.000$

ORIENTATION $=\begin{array}{lllllllll}1.00 & 0.00 & 0.00 & 0.00 & 1.00 & 0.00 & 0.00 & 0.00 & 1.00\end{array}$

ACTIVE COORDINATE SYSTEM SET TO 11 (CARTESIAN)

PREP7:

ACTIVE COORDINATE SYSTEM SET TO 11 (CARTESIAN)

PREP7:

REAL CONSTANT NUMBER $=1$

PREP7:

COORDINATE SYSTEM 12 DEFINITION. TYPE $=1$ (CYLINDRICAL)

$X C, Y C, Z C=71.500 \quad 0.00000 E+000.00000 E+00$

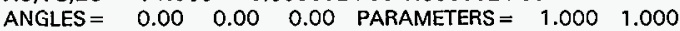

ORIENTATION $=\begin{array}{lllllllll}1.00 & 0.00 & 0.00 & 0.00 & 1.00 & 0.00 & 0.00 & 0.00 & 1.00\end{array}$

ACTIVE COORDINATE SYSTEM SET TO 12 (CYLINDRICAL)

PREP7:

ACTIVE COORDINATE SYSTEM SET TO 12 (CYLINDRICAL)

PREP7:

NODE $1100 \mathrm{KCS}=12 \quad X, Y, Z=25.000 \quad 0.00000 E+000.10000 \mathrm{E}-01$

PREP7:

NODE $1108 \mathrm{KCS}=12 \quad \mathrm{X}, \mathrm{Y}, Z=25.000 \quad 90.000 \quad 0.10000 \mathrm{E}-01$

PREP7:

FILL 7 POINTS BETWEEN NODE 1100 AND NODE 1108

START WITH NODE 1101 AND INCREMENT BY 1 


$$
\begin{array}{r}
\text { HNF-SD-TWR-CN-002 } \\
\text { Rev. } 0 \\
\text { Appendix A }
\end{array}
$$

PREP7:

NODE $1116 \quad K C S=12 \quad X, Y, Z=25.000 \quad 180.00 \quad 0.10000 E-01$

PREP7:

FILL 7 POINTS BETWEEN NODE 1108 AND NODE 1116

START WITH NODE 1109 AND INCREMENT BY 1

PREP7:

NODE $1117 \mathrm{KCS}=12 \quad X, Y, Z=25.000 \quad-168.75 \quad 0.10000 E-01$

PREP7:

NODE $1124 \quad K C S=12 \quad X, Y, Z=25.000 \quad-90.000 \quad 0.10000 E-01$

PREP7:

FILL 6 POINTS BETWEEN NODE 1117 AND NODE 1124

START WITH NODE 1118 AND INCREMENT BY 1

PREP7:

NODE $1131 \mathrm{KCS}=12 \quad \mathrm{X}, \mathrm{Y}, \mathrm{Z}=, 25.000 \quad-11.250 \quad 0.10000 \mathrm{E}-01$

PREP7:

FILL 6 POINTS BETWEEN NODE 1124 AND NODE 1131

START WITH NODE 1125 AND INCREMENT BY 1

PREP7:

GENERATE 3 TOTAL SETS OF NODES WITH INCREMENT 32

SET IS SELECTED NODES IN RANGE 1100 TO 1131 IN STEPS OF 1

GEOMETRY INCREMENTS ARE $2.5000 \quad 0.00000 \mathrm{E}+00 \quad 0.00000 \mathrm{E}+00$ SPACING $=1.0000$

PREP7:

ELEMENT TYPE SET TO 1

PREP7:

REAL CONSTANT NUMBER $=1$

PREP7:

ELEMENT $\quad 495 \quad 1116 \quad 1148 \quad 1149 \quad 1117$

PREP7:

GENERATE 15 TOTAL SETS OF ELEMENTS WITH NODE INCREMENT OF 1 


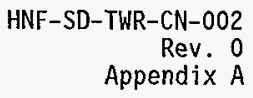

SET IS SELECTED ELEMENTS IN RANGE 495 TO 495 IN STEPS OF 1 MAXIMUM ELEMENT NUMBER $=509$

PREP7:

ELEMENT $\quad 510 \quad 1131 \quad 1163 \quad 1132 \quad 1100$

PREP7:

GENERATE 2 TOTAL SETS OF ELEMENTS WITH NODE INCREMENT OF 32

SET IS SELECTED ELEMENTS IN RANGE 495 TO 510 IN STEPS OF 1

MAXIMUM ELEMENT NUMBER $=\mathbf{5 2 6}$

PREP7:

ACTIVE COORDINATE SYSTEM SET TO O (CARTESIAN)

PREP7:

GENERATE 2 TOTAL SETS OF NODES WITH INCREMENT 30000

SET IS SELECTED NODES IN RANGE 454 TO 459 IN STEPS OF 1

GEOMETRY INCREMENTS ARE 0.00000E + 00 0.00000E + 00 0.10000E-01 SPACING $=1.0000$

PREP7:

GENERATE 2 TOTAL. SETS OF NODES WITH INCREMENT 30000

SET IS SELECTED NODES IN RANGE 474 TO 574 IN STEPS OF 10

GEOMETRY INCREMENTS ARE $0.00000 E+00$ 0.00000E $+000.10000 E-01$ SPACING $=1.0000$

PREP7:

GENERATE 2 TOTAL SETS OF NODES WITH INCREMENT 30000

SET IS SELECTED NODES IN RANGE 546 TO 549 IN STEPS OF 1

GEOMETRY INCREMENTS ARE $0.00000 E+000,00000 E+000.10000 E-01$ SPACING $=1.0000$

PREP7:

GENERATE 2 TOTAL SETS OF NODES WITH INCREMENT 30000

SET IS SELECTED NODES IN RANGE 556 TO 559 IN STEPS OF 1

GEOMETRY INCREMENTS ARE 0.00000E + 00 0.00000E +00 0.10000E-01 SPACING $=1.0000$

PREP7:

GENERATE 2 TOTAL. SETS OF NODES WITH INCREMENT 30000 SET IS SELECTED NODES IN RANGE 575 TO 579 IN STEPS OF 1 GEOMETRY INCREMENTS ARE 0.00000E + 00 0.00000E + 00 0.10000E-01 SPACING $=1.0000$

PREP7:

$\begin{array}{llllll}\text { ELEMENT } & 527 & 1180 & 30459 & 30458 & 1181\end{array}$

PREP7: 
HNF-SD-TWR-CN-002

Rev. 0

Appendix A

$\begin{array}{llllll}\text { ELEMENT } & 528 & 1181 & 30458 & 30457 & 1182\end{array}$

PREP7:

$\begin{array}{llllll}\text { ELEMENT } & 529 & 1182 & 30457 & 30456 & 1183\end{array}$

PREP7:

$\begin{array}{llllll}\text { ELEMENT } & 530 & 1183 & 30456 & 30454 & 1184\end{array}$

PREP7:

$\begin{array}{llllll}\text { ELEMENT } & 531 & 1184 & 30454 & 30474 & 1185\end{array}$

PREP7:

$\begin{array}{llllll}\text { ELEMENT } & 532 & 1185 & 30474 & 30484 & 1186\end{array}$

PREP7:

$\begin{array}{llllll}\text { ELEMENT } & 533 & 1186 & 30484 & 30494 & 1187\end{array}$

PREP7:

$\begin{array}{lllllll}\text { ELEMENT } & 534 & 1187 & 30494 & 30504 & 1188\end{array}$

PREP7:

$\begin{array}{llllll}\text { ELEMENT } & 535 & 1188 & 30504 & 30514 & 1189\end{array}$

PREP7:

ELEMENT $\quad 536 \quad 1189 \cdot 30514 \quad 30524 \quad 1190$

PREP7:

ELEMENT $\quad 537 \quad 1190 \quad 30524 \quad 30534 \quad 1191$

PREP7:

$\begin{array}{llllll}\text { ELEMENT } & 538 & 1191 & 30534 & 30544 & 1192\end{array}$

PREP7:

$\begin{array}{llllll}\text { ELEMENT } & 539 & 1192 & 30544 & 30546 & 1193\end{array}$

PREP7:

$\begin{array}{llllll}\text { ELEMENT } & 540 & 1193 & 30546 & 30547 & 1194\end{array}$

PREP7: 
ELEMENT $\quad 541 \quad 1194 \quad 30547 \quad 30548 \quad 1195$

PREP7:

ELEMENT $\quad 542 \quad 1195 \quad 30548 \quad 30549 \quad 1164$

PREP7:

$\begin{array}{llllll}\text { ELEMENT } & 543 & 544 & 554 & 556 & 546\end{array}$

PREP7:

$\begin{array}{llllll}\text { ELEMENT } & 544 & 546 & 556 & 557 & 547\end{array}$

PREP7:

GENERATE 3 TOTAL SETS OF ELEMENTS WITH NODE INCREMENT OF 1 SET IS SELECTED ELEMENTS IN RANGE 544 TO 544 IN STEPS OF 1 MAXIMUM ELEMENT NUMBER $=546$

PREP7:

ELEMENT $\quad 547 \quad 554 \quad 574 \quad 576 \quad 556$

PREP7:

ELEMENT $\quad 548 \quad 556 \quad 576 \quad 577 \quad 557$

PREP7:

GENERATE 3 TOTAL SETS OF ELEMENTS WITH NODE INCREMENT OF 1 SET IS SELECTED ELEMENTS IN RANGE 548 TO 548 IN STEPS OF 1 MAXIMUM ELEMENT NUMBER $=550$

PREP7:

COUPLED SET $=1$ DIRECTION $=U Z$ TOTAL NODES $=2$ NODES ADDED $=45730457$

MAXIMUM COUPLED SET NUMBER $=1$

PREP7:

COUPLED SET $=2$ DIRECTION $=U Z$ TOTAL NODES $=2$ NODES ADDED $=47430474$

MAXIMUM COUPLED SET NUMBER $=2$

PREP7:

COUPLED SET $=3$ DIRECTION $=U Z$ TOTAL NODES $=2$ NODES ADDED $=49430494$

MAXIMUM COUPLED SET NUMBER $=3$ 
PREP7:

COUPLED SET $=4$ DIRECTION $=$ UZ TOTAL NODES $=2$ NODES ADDED $=51430514$

MAXIMUM COUPLED SET NUMBER $=4$

PREP7:

COUPLED SET $=5$ DIRECTION $=$ UZ TOTAL NODES $=2$ NODES ADDED $=53430534$

MAXIMUM COUPLED SET NUMBER $=5$

PREP7:

COUPLED SET $=6$ DIRECTION $=$ UZ TOTAL NODES $=2$ NODES ADDED $=57730577$

MA'XIMUM COUPLED SET NUMBER $=6$

PREP7:

COUPLED SET $=7$ DIRECTION $=U X \quad$ TOTAL NODES $=2$ NODES ADDED $=45730457$

MAXIMUM COUPLED SET NUMBER $=7$

PREP7:

COUPLED SET $=8$ DIRECTION $=U X \quad$ TOTAL NODES $=2$ NODES ADDED $=47430474$

MAXIMUM COUPLED SET NUMBER $=8$

PREP7:

COUPLED SET $=9$ DIRECTION $=U X \quad$ TOTAL NODES $=2$ NODES ADDED $=49430494$

MAXIMUM COUPLED SET NUMBER $=9$

PREP7:

COUPLED SET $=10$ DIRECTION $=U X \quad$ TOTAL NODES $=2$ NODES ADDED $=51430514$

MAXIMUM COUPLED SET NUMBER $=10$

PREP7:

COUPLED SET $=11$ DIRECTION $=$ UX $\quad$ TOTAL NODES $=2$ NODES ADDED $=53430534$

MAXIMUM COUPLED SET NUMBER $=11$

PREP7:

COUPLED SET $=12$ DIRECTION $=U X \quad$ TOTAL NODES $=2$ NODES ADDED $=57730577$ 
PREP7:

COUPLED SET $=13$ DIRECTION $=$ UY TOTAL NODES $=2$ NODES ADDED $=45730457$

MAXIMUM COUPLED SET NUMBER $=13$

PREP7:

COUPLED SET $=14$ DIRECTION $=$ UY TOTAL NODES $=2$

NODES ADDED $=47430474$

MAXIMUM COUPLED SET NUMBER $=14$

PREP7:

COUPLED SET $=15$ DIRECTION $=$ UY TOTAL NODES $=2$ NODES ADDED $=49430494$

MAXIMUM COUPLED SET NUMBER $=15$

PREP7:

COUPLED SET $=16$ DIRECTION $=$ UY TOTAL NODES $=2$ NODES ADDED $=51430514$

MAXIMUM COUPLED SET NUMBER $=16$

PREP7:

COUPLED SET $=17$ DIRECTION $=$ UY TOTAL NODES $=2$ NODES ADDED $=53430534$

MAXIMUM COUPLED SET NUMBER $=17$

PREP7:

COUPLED SET $=18$ DIRECTION $=$ UY TOTAL NODES $=2$ NODES ADDED $=57730577$

MAXIMUM COUPLED SET NUMBER $=18$

PREP7:

ELEMENT TYPE 5 IS COMBIN 14 SPRING-DAMPER $\operatorname{KEYOPT}(1-12)=\begin{array}{llllllllllll}0 & 1 & 0 & 0 & 0 & 0 & 0 & 0 & 0 & 0 & 0 & 0\end{array}$

CURRENT NODAL DOF SET IS UX UY UZ ROTX ROTY ROTZ THREE-DIMENSIONAL MODEL

PREP7:

REAL CONSTANT SET 12 ITEMS 1 TO 6

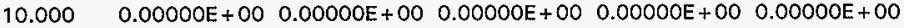

PREP7: 


$$
\begin{array}{r}
\text { HNF-SD-TWR-CN-O02 } \\
\text { Rev. } 0 \\
\text { Appendix A }
\end{array}
$$

\section{ELEMENT TYPE SET TO 5}

PREP7:

REAL CONSTANT NUMBER $=12$

PREP7:

GENERATE 2 TOTAL SETS OF NODES WITH INCREMENT 6000

SET IS SELECTED NODES IN RANGE 4303 TO 4303 IN STEPS OF 1

GEOMETRY INCREMENTS ARE-0.10000E-01 $0.00000 \mathrm{E}+000.00000 \mathrm{E}+00 \mathrm{SPACING}=1.0000$

PREP7:

ELEMENT $\quad 551 \quad 4303 \quad 10303$

PREP7:

GENERATE 2 TOTAL SETS OF NODES WITH INCREMENT 6000 SET IS SELECTED NODES IN RANGE 4583 TO 4583 IN STEPS OF 1 GEOMETRY INCREMENTS ARE $0.10000 \mathrm{E}-010.00000 \mathrm{E}+00 \quad 0.00000 \mathrm{E}+00$ SPACING $=1.0000$

PREP7:

ELEMENT $\quad 552 \quad 4583 \quad 10583$

PREP7:

ELEMENT TYPE 6 IS COMBIN14 SPRING-DAMPER

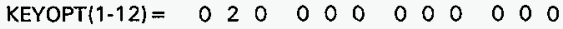

CURRENT NODAL DOF SET IS UX UY UZ ROTX ROTY ROTZ

THREE-DIMENSIONAL MODEL.

PREP7:

REAL CONSTANT SET 13 ITEMS 1 TO 6

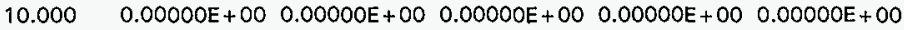

PREP7:

ELEMENT TYPE SET TO 6

PREP7:

REAL CONSTANT NUMBER $=13$

PREP7:

GENERATE 2 TOTAL SETS OF NODES WITH INCREMENT 6000

SET IS SELECTED NODES IN RANGE 4340 TO 4340 IN STEPS OF 1

GEOMETRY INCREMENTS ARE $0.00000 E+00-0.10000 \mathrm{E}-010.00000 \mathrm{E}+00$ SPACING $=1.0000$ 


$$
\begin{array}{r}
\text { HNF-SD-TWR-CN-002 } \\
\text { Rev. } 0 \\
\text { Appendix A }
\end{array}
$$

PREP7:

ELEMENT $\quad 553 \quad 4340 \quad 10340$

PREP7:

GENERATE 2 TOTAL SETS OF NODES WITH INCREMENT 6000

SET IS SELECTED NODES IN RANGE 4440 TO 4440 IN STEPS OF 1

GEOMETRY INCREMENTS ARE $0.00000 \mathrm{E}+00-0.10000 \mathrm{E}-01 \quad 0.00000 \mathrm{E}+00$ SPACING $=1.0000$

PREP7:

ELEMENT $\quad 554 \quad 4440 \quad 10440$

PREP7:

SELECT FOR ITEM $=$ NODE COMPONENT =

IN RANGE 10303 TO 10303 STEP . 1

1 NODES (OF 779 DEFINED) SELECTED BY NSEL COMMAND.

PREP7:

ALSO SELECT FOR ITEM = NODE COMPONENT = IN RANGE 10583 TO 10583 STEP 1

2 NODES (OF 779 DEFINED) SELECTED BY NSEL COMMAND.

PREP7:

ALSO SELECT FOR ITEM $=$ NODE COMPONENT $=$ IN RANGE 10340 TO 10340 STEP 1

3 NODES (OF 779 DEFINED) SELECTED BY NSEL COMMAND.

PREP7:

ALSO SELECT FOR ITEM = NODE COMPONENT = IN RANGE 10440 TO 10440 STEP 1

4 NODES (OF 779 DEFINED) SELECTED BY NSEL. COMMAND.

PREP7:

SPECIFIED CONSTRAINT UX FOR SELECTED NODES 1 TO 30579 BY 1

REAL $=0.000000000 E+00 \quad I M A G=0.000000000 E+00$

ADDITIONAL DOFS $=$ UY UZ ROTX ROTY ROTZ

PREP7:

SELECT ALL ENTITIES OF TYPE = ALL AND BELOW 
HNF-SD-TWR-CN-002

Rev. 0

Appendix A

\begin{abstract}
ALL SELECT FOR ITEM = VOLU COMPONENT = IN RANGE O TO O STEP 1

O VOLUMES (OF O DEFINED) SELECTED BY VSEL COMMAND.
\end{abstract}

ALL SELECT FOR ITEM $=$ AREA COMPONENT $=$ IN RANGE $\quad O$ TO O STEP 1

- AREAS (OF O DEFINED) SELECTED BY ASEL COMMAND.

ALL SELECT FOR ITEM $=$ LINE COMPONENT $=$ IN RANGE O TO O STEP 1

O LINES (OF O DEFINED) SELECTED BY LSEL COMMAND.

ALL SELECT FOR ITEM $=$ KP COMPONENT = IN RANGE O TO O STEP 1

0 KEYPOINTS (OF 0 DEFINED) SELECTED BY KSEL COMMAND.

ALL SELECT FOR ITEM $=$ ELEM COMPONENT $=$

IN RANGE 1 TO 554 STEP 1

554 ELEMENTS (OF 554 DEFINED) SELECTED BY ESEL COMMAND.

ALL SELECT FOR ITEM $=$ NODE COMPONENT $=$ IN RANGE 1 TO 30579 STEP 1

779 NODES (OF 779 DEFINED) SELECTED BY NSEL COMMAND.

PREP7:

ACTIVE COORDINATE SYSTEM SET TO O (CARTESIAN')

PREP7:

GENERATE 2 TOTAL SETS OF NODES WITH INCREMENT 6000

SET IS SELECTED NODES IN RANGE 4560 TO 4569 IN STEPS OF 1

GEOMETRY INCREMENTS ARE $0.00000 E+000.00000 \mathrm{E}+00-0.10000 \mathrm{E}-01 \mathrm{SPACING}=1.0000$

PREP7:

GENERATE 2 TOTAL SETS OF NODES WITH INCREMENT 6000

SET IS SELECTED NODES IN RANGE 4303 TO 4340 IN STEPS OF 37

GEOMETRY INCREMENTS ARE $0.00000 \mathrm{E}+000.00000 \mathrm{E}+00-0.10000 \mathrm{E}-01$ SPACING $=1.0000$

PREP7:

GENERATE 2 TOTAL SETS OF NODES WITH INCREMENT 6000

SET IS SELECTED NODES IN RANGE 4440 TO 4440 IN STEPS OF 1

GEOMETRY INCREMENTS ARE $0.00000 E+000.00000 \mathrm{E}+00-0.10000 \mathrm{E}-01 \mathrm{SPACING}=1.0000$ 
PREP7:

ELEMENT TYPE 2 IS CONTAC52 3-D INTERFACE

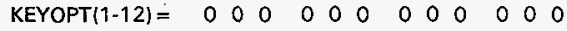

INOPR $=1$

CURRENT NODAL DOF SET IS UX UY UZ ROTX ROTY ROTZ

THREE-DIMENSIONAL MODEL

PREP7:

REAL CONSTANT SET 11 ITEMS 1 TO 6

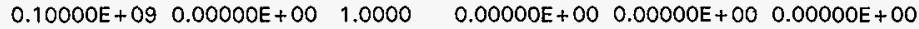

PREP7:

REAL CONSTANT SET 20 ITEMS 1 TO 6

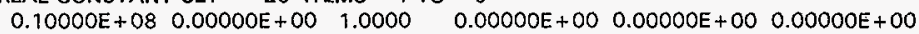

PREP7:

ELEMENT TYPE SET TO 2

PREP7:

REAL CONSTANT NUMBER $=11$

PREP7:

ELEMENT $555 \quad 10560 \quad 4560$

PREP7:

GENERATE 4 TOTAL SETS OF ELEMENTS WITH NODE INCREMENT OF 1 SET IS SELECTED ELEMENTS IN RANGE 555 TO 555 IN STEPS OF 1 MAXIMUM ELEMENT NUMBER $=558$

PREP7:

ELEMENT $\quad 559 \quad 10565 \quad 4565$

PREP7:

GENERATE 5 TOTAL SETS OF ELEMENTS WITH NODE INCREMENT OF 1 SET IS SELECTED ELEMENTS IN RANGE 559 TO. 559 IN STEPS OF 1 MAXIMUM ELEMENT NUMBER $=563$

PREP7:

ELEMENT $564 \quad 10303 \quad 4303$

PREP7: 
ELEMENT $\quad 565 \quad 10340 \quad 4340$

PREP7:

ELEMENT $\quad 566 \quad 10440 \quad 4440$

PREP7:

SELECT FOR ITEM $=$ NODE COMPONENT $=$

IN RANGE 10560 TO 10563 STEP 1

4 NODES (OF 789 DEFINED) SELECTED BY NSEL COMMAND.

PREP7:

ALSO SELECT FOR ITEM $=$ NODE COMPONENT $=$ IN RANGE 10565 TO 10569 STEP 1

9 NODES (OF 789 DEFINED) SELECTED BY NSEL COMMAND.

PREP7:

ALSO SELECT FOR ITEM $=$ NODE COMPONENT $=$ IN RANGE 10440 TO 10440 STEP 1

10 NODES (OF 789 DEFINED) SELECTED BY NSEL COMMAND.

PREP7:

ALSO SELECT FOR ITEM = NODE COMPONENT = IN RANGE 10340 TO 10340 STEP 1

11 NODES (OF 789 DEFINED) SELECTED BY NSEL COMMAND.

PREP7:

ALSO SELECT FOR ITEM $=$ NODE COMPONENT $=$ IN RANGE 10303 TO 10303 STEP 1

12 NODES (OF 789 DEFINED) SELECTED BY NSEL COMMAND.

PREP7:

SPECIFIED CONSTRAINT UX FOR SELECTED NODES $\quad 1$ TO $30579 \mathrm{BY} \quad 1$

REAL $=0.000000000 E+00 \quad I M A G=0.000000000 E+00$

ADDITIONAL DOFS $=$ UY UZ ROTX ROTY ROTZ

PREP7:

SELECT ALL ENTITIES OF TYPE = ALL AND BELOW

ALL SELECT FOR ITEM $=$ VOLU COMPONENT $=$ 
IN RANGE O TO O STEP 1

O VOLUMES (OF O DEFINEDI SELECTED BY VSEL COMMAND.

\begin{abstract}
ALL SELECT FOR ITEM $=$ AREA COMPONENT $=$
\end{abstract} IN RANGE O TO OSTEP 1

O AREAS (OF O DEFINED) SELECTED BY ASEl COMMAND.

ALL SELECT FOR ITEM $=$ LINE COMPONENT = IN RANGE O TO O STEP 1

O LINES (OF O DEFINED) SELECTED BY LSEL COMMAND.

ALL SELECT FOR ITEM $=$ KP COMPONENT $=$ IN RANGE O TO O STEP 1

O KEYPOINTS (OF O DEFINED) SELECTED BY KSEL COMMAND.

ALL SELECT FOR ITEM $=$ ELEM COMPONENT $=$ IN RANGE 1 TO 566 STEP 1

566 ELEMENTS (OF 566 DEFINED) SELECTED BY ESEL COMMAND.

ALL SELECT FOR ITEM $=$ NODE COMPONENT $=$ IN RANGE 1 TO 30579 STEP 1

789 NODES (OF 789 DEFINED) SELECTED BY NSEL COMMAND.

PREP7:

DELETE SELECTED NODES FROM 366 TO $369 \mathrm{BY} \quad 1$

PREP7:

DELETE SELECTED NODES FROM 376 TO 379 BY 1

PREP7:

DELETE SELECTED NODES FROM 386 TO 389 BY 1

PREP7:

DELETE SELECTED NODES FROM 396 TO 399 BY 1

PREP7:

DELETE SELECTEO NODES FROM 406 TO $409 \mathrm{BY} 1$

PREP7:

DELETE SELECTED NODES FROM 416 TO 419 BY 1 
HNF-SD-TWR-CN-002

Rev. 0

Appendix A

PREP7:

DELETE SELECTED NODES FROM 426 TO 429 BY 1

PREP7:

DELETE SELECTED NODES FROM 476 TO $479 \mathrm{BY} \quad 1$

PREP7:

DELETE SELECTED NODES FROM 486 TO 489 BY 1

PREP7:

DELETE SELECTED NODES FROM 496 TO 499 BY 1

PREP7:

DELETE SELECTED NODES FROM 506 TO 509 BY 1

PREP7:

DELETE SELECTED NODES FROM 516 TO $519 \mathrm{BY} \quad 1$

PREP7:

DELETE SELECTED NODES FROM 526 TO 529 BY 1

PREP7:

DELETE SELECTED NODES FROM 536 TO 539 BY 1

PREP7:

ELEMENT TYPE SET TO 2

PREP7:

REAL CONSTANT NUMBER $=20$

PREP7:

ELEMENT $\quad 567 \quad 458 \quad 30458$

PREP7:

GENERATE 2 TOTAL SETS OF ELEMENTS WITH NODE INCREMENT OF 1 SET IS SELECTED ELEMENTS IN RANGE 567 TO 567 IN STEPS OF 1 MAXIMUM ELEMENT NUMBER $=568$

PREP7: 
HNF-SD-TWR-CN-002

Rev. 0

Appendix $A$

ELEMENT $\quad 569 \quad 456 \quad 30456$

PREP7:

ELEMENT $\quad 570 \quad 454 \quad 30454$

PREP7:

ELEMENT $\quad 571 \quad 484 \quad 30484$

PREP7:

ELEMENT $\quad 572 \quad 504 \quad 30504$

PREP7:

ELEMENT $\quad 573 \quad 524 \quad 30524$

PREP7:

ELEMENT $\quad 574 \quad 554 \quad 30554$

PREP7:

ELEMENT $\quad 575 \quad 574 \quad 30574$

PREP7:

ELEMENT ' $576 \quad 575 \quad 30575$

PREP7:

ELEMENT $577 \quad 576 \quad 30576$

PREP7:

$\begin{array}{llll}\text { ELEMENT } & 578 & 578 & 30578\end{array}$

PREP7:

ELEMENT $\quad 579 \quad 579 \quad 30579$

PREP7:

ELEMENT $\quad 580 \quad 546 \quad 30546$

PREP7:

GENERATE 4 TOTAL SETS OF ELEMENTS WITH NODE INCREMENT OF 1 SET IS SELECTED ELEMENTS IN RANGE 580 TO 580 IN STEPS OF 1 MAXIMUM ELEMENT NUMBER $=583$ 
PREP7:

ACTIVE COORDINATE SYSTEM SET TO 11 (CARTESIAN)

PREP7:

ELEMENT TYPE SET TO

PREP7:

MATERIAL NUMBER SET TO 2

PREP7:

REAL CONSTANT SET 8 ITEMS 1 TO 6

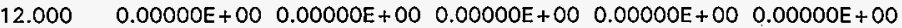

PREP7:

REAL CONSTANT NUMBER $=8$

PREP7:

NODE $21001 \mathrm{KCS}=11 \quad \mathrm{X}, \mathrm{Y}, \mathrm{Z}=-16.000 \quad-16.000 \quad 20.000$

PREP7:

NODE $21009 \mathrm{KCS}=11 \quad X, Y, Z=16.000 \quad-16.000 \quad 20.000$

PREP7:

FILL 7 POINTS BETWEEN NODE 21001 AND NODE 21009

START WITH NODE 21002 AND INCREMENT BY 1

PREP7:

GENERATE 5 TOTAL SETS OF NODES WITH INCREMENT 9 SET IS SELECTED NODES IN RANGE 21001 TO 21009 IN STEPS OF .1 GEOMETRY INCREMENTS ARE $0.00000 E+00 \quad 4.0000 \quad 0.00000 E+00$ SPACING $=1.0000$

PREP7:

ELEMENT $\quad 58421001210022101121010$

PREP7:

GENERATE 8 TOTAL SETS OF ELEMENTS WITH NODE INCREMENT OF 1 SET IS SELECTED ELEMENTS IN RANGE 584 TO 584 IN STEPS OF 1 MAXIMUM ELEMENT NUMBER $=591$

PREP7: 
GENERATE 4 TOTAL SETS OF ELEMENTS WITH NODE INCREMENT OF 9 SET IS SELECTED ELEMENTS IN RANGE 584 TO 591 IN STEPS OF 1 MAXIMUM ELEMENT NUMBER $=615$

PREP7:

ACTIVE COORDINATE SYSTEM SET TO 12 (CYLINDRICAL)

PREP7:

NODE $21100 \mathrm{KCS}=12 \quad X, Y, Z=25.000 \quad 0.00000 E+00 \quad 20.000$

PREP7:

NODE $21108 \mathrm{KCS}=12 \quad \mathrm{X}, \mathrm{Y}, \mathrm{Z}=25.000 \quad 90.000 \quad 20.000$

PREP7:

FILL 7 POINTS BETWEEN NODE 21100 AND NODE 21108

START WITH NODE 21101 AND INCREMENT BY 1

PREP7:

NODE $21116 \mathrm{KCS}=12 \quad \mathrm{X}, \mathrm{Y}, \mathrm{Z}=25.000 \quad 180.00 \quad 20.000$

PREP7:

FILL 7 POINTS BETWEEN NODE 21108 AND NODE 21116 START WITH NODE 21109 AND INCREMENT BY 1

PREP7:

NODE $21117 \mathrm{KCS}=12 \quad X, Y, Z=25.000 \quad-168.75 \quad 20.000$

PREP7:

NODE $21124 \mathrm{KCS}=12 \quad X, Y, Z=25.000 \quad-90.000 \quad 20.000$

PREP7:

FILL 6 POINTS BETWEEN NODE 21117 AND NODE 21124 START WITH NODE 21118 AND INCREMENT BY 1

PREP7:

NODE 21131 KCS $=12 \quad X, Y, Z=25.000-11.250 \quad 20.000$

PREP7:

FILL 6 POINTS BETWEEN NODE 21124 AND NODE 21131

START WITH NODE 21125 AND INCREMENT BY 1 
PREP7:

ELEMENT $616 \quad 21037 \quad 21116 \quad 21117 \quad 21028$

PREP7:

ELEMENT $\begin{array}{llllll}617 & 21028 & 21117 & 21118 & 21019\end{array}$

PREP7:

ELEMENT $618 \quad 2101921118 \quad 21119 \quad 21010$

PREP7:

ELEMENT $\quad 619 \quad 2101021119 \quad 21120 \quad 21001$

PREP7:

ELEMENT $\quad 620 \quad 21001 \quad 2112021121 \quad 21002$

PREP7:

ELEMENT $\quad 621 \quad 21002 \quad 21121 \quad 21122 \quad 21003$

PREP7:

ELEMENT $622 \quad 21003 \quad 21122 \quad 21123 \quad 21004$

PREP7:

ELEMENT $\quad 623 \quad 2100421123 \quad 21124 \quad 21005$

PREP7:

ELEMENT $\quad 624 \quad 21005 \quad 211242112521006$

PREP7:

ELEMENT $\quad 625 \quad 21006 \quad 21125 \quad 21126 \quad 21007$

PREP7:

ELEMENT $\quad 626 \quad 21007 \quad 21126 \quad 21127 \quad 21008$

PREP7:

ELEMENT $\quad 627 \quad 21008 \quad 21127 \quad 21128 \quad 21009$

PREP7:

ELEMENT $\quad 628 \quad 21009 \quad 21128 \quad 21129 \quad 21018$ 
HNF-SD-TWR-CN-002

Rev. 0

Appendix A

PREP7:

ELEMENT $\quad 629 \quad 21018 \quad 2112921130 \quad 21027$

PREP7:

ELEMENT $\quad 630 \quad 21027 \quad 21130 \quad 21131 \quad 21036$

PREP7:

ELEMENT $\quad 631 \quad 21036 \quad 2113121100 \quad 21045$

PREP7:

GENERATE 3 TOTAL SETS OF NODES WITH INCREMENT 32

SET IS SELECTED NODES IN RANGE 21100 TO 21131 IN STEPS OF 1

GEOMETRY INCREMENTS ARE $2.5000 \quad 0.00000 \mathrm{E}+00 \quad 0.00000 \mathrm{E}+00$ SPACING $=1.0000$

PREP7:

ELEMENT $\quad \begin{array}{llllll}632 & 21116 & 21148 & 21149 & 21117\end{array}$

PREP7:

GENERATE 15 TOTAL SETS OF ELEMENTS WITH NODE INCREMENT OF 1 SET IS SELECTED ELEMENTS IN RANGE 632 TO 632 IN STEPS OF 1 MAXIMUM ELEMENT NUMBER $=646$

PREP7:

ELEMENT $647 \quad 21131 \quad 21163 \quad 21132 \quad 21100$

PREP7:

GENERATE 2 TOTAL. SETS OF ELEMENTS WITH NODE INCREMENT OF 32 SET IS SELECTED ELEMENTS IN RANGE 632 TO 647 IN STEPS OF 1 MAXIMUM ELEMENT NUMBER $=663$

PREP7:

ELEMENT TYPE 3 IS COMBIN4O COMBINATION $\operatorname{KEYOPT}(1-12)=0 \begin{array}{llllllllllll}0 & 0 & 3 & 0 & 0 & 0 & 0 & 0 & 0 & 0 & 0 & 0\end{array}$

CURRENT NODAL DOF SET IS UX UY UZ ROTX ROTY ROTZ THREE-DIMENSIONAL MODEL

PREP7:

REAL CONSTANT SET 9 ITEMS 1 TO 6 50000. $0.00000 E+00 \quad 0.00000 E+00 \quad 0.00000 E+00 \quad 10000 . \quad 0.00000 E+00$

PREP7: 
REAL. CONSTANT SET 10 ITEMS 1 TO 6

25000. $\quad 0.00000 E+00 \quad 0.00000 E+00 \quad 0.00000 E+00 \quad 5000.0 \quad 0.00000 E+00$

PREP7:

ELEMENT TYPE SET TO 3

PREP7:

REAL CONSTANT NUMBER $=9$

PREP7:

ELEMENT $\quad 664 \quad 118121181$

PREP7:

GENERATE 15 TOTAL SETS OF ELEMENTS WITH NODE INCREMENT OF 1

SET IS SELECTED ELEMENTS IN RANGE 664 TO 664 IN STEPS OF 1

MAXIMUM ELEMENT NUMBER $=678$

PREP7:

REAL CONSTANT NUMBER $=10$

PREP7:

ELEMENT $\quad 679 \quad 1180 \quad 21180$

PREP7:

ELEMENT $\quad 680 \quad 116421164$

PREP7:

SPECIFIED CONSTRAINT UX FOR SELECTED NODES 21188 TO $21188 \mathrm{BY} \quad 1$

REAL $=0.000000000 E+00 \quad$ IMAG $=0.000000000 E+00$

ADDITIONAL DOFS = UY ROTX ROTY ROTZ

PREP7:

SELECT ALL ENTITIES OF TYPE $=$ ALL AND BELOW $\begin{array}{lll}\text { ALL SELECT } & \text { FOR ITEM }=\text { VOLU COMPONENT }= \\ \text { IN RANGE } & \text { O TO } & \text { O STEP } \\ 1\end{array}$

0 VOLUMES (OF O DEFINED) SELECTED BY VSEL COMMAND.

ALL SELECT FOR ITEM = AREA COMPONENT $=$ IN RANGE O TO O STEP 1

0 AREAS (OF O DEFINED) SELECTED BY ASEL COMMAND. 
ALL SELECT FOR ITEM = LINE COMPONENT = IN RANGE O TO OSTEP 1 .

0 LINES (OF O DEFINED) SELECTED BY LSEL COMMAND.

ALL SELECT FOR ITEM $=\mathrm{KP} \quad$ COMPONENT $=$ IN RANGE OTO O STEP 1

O KEYPOINTS (OF O DEFINED) SELECTED BY KSEL COMMAND.

ALL SELECT FOR ITEM = ELEM COMPONENT $=$ IN RANGE 1 TO 680 STEP 1

680 ELEMENTS (OF 680 DEFINED) SELECTED BY ESEL COMMAND.

ALL SELECT FOR ITEM = NODE COMPONENT = IN RANGE 1 TO 30579 STEP 1

874 NODES (OF 874 DEFINED) SELECTED BY NSEL COMMAND.

PREP7:

ELEMENT TYPE 4 IS COMBIN40 COMBINATION

KEYOPT $(1-12)=\begin{array}{llllllllllll}1 & 0 & 3 & 0 & 0 & 2 & 0 & 0 & 0 & 0 & 0 & 0\end{array}$

CURRENT NODAL DOF SET IS UX UY UZ ROTX ROTY ROTZ THREE-DIMENSIONAL MODEL

PREP7:

PARAMETER G $=386.4000$

PREP7:

REAL CONSTANT SET 11 ITEMS 1 TO 6

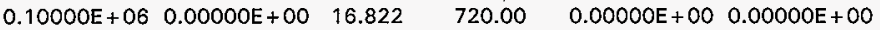

PREP7:

GENERATE 2 TOTAL SETS OF NODES WITH INCREMENT 3000

SET IS SELECTED NODES IN RANGE 21041 TO 21041 IN STEPS OF 1

GEOMETRY INCREMENTS ARE $0.00000 E+000.00000 E+00720.00 \quad$ SPACING $=1.0000$

PREP7:

ELEMENT TYPE SET TO 4

PREP7:

REAL CONSTANT NUMBER $=11$

PREP7: 
HNF-SD-TWR-CN-002

Rev. 0

Appendix A

ELEMENT $681 \quad 2104124041$

PREP7:

UNIFORM TEMPERATURE $=70.000($ TREF $=0.000)$

PREP7:

ACTIVE COORDINATE SYSTEM SET TO 13 (CARTESIAN)

PREP7:

SELECT FOR ITEM $=$ LOC $\quad$ COMPONENT $=\mathrm{Y}$ BETWEEN $59.740 \quad$ AND 59.760

$\mathrm{KABS}=0$. TOLERANCE $=0.000000 E+00$

71 NODES (OF 875 DEFINED) SELECTED BY NSEL COMMAND.

PREP7:

SYMMETRY CONSTRAINTS FOR COORDINATE SYSTEM 13 IN DIRECTION Y ON SURFACE DEFINED BY ALI. SELECTED NODES

*** NOTE *** CP= 8.850 TIME $=11: 38: 19$

Nodes on symmetry surfaces are rotated into coordinate system 13 .

TOTAL SPECIFIED CONSTRAINTS $=293$

PREP7:

SELECT ALL ENTITIES OF TYPE = ALL AND BELOW

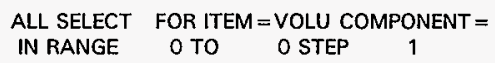

0 VOLUMES IOF O DEFINEDI SELECTED BY VSEL COMMAND.

$\begin{array}{ccc}\text { ALL SELECT } & \text { FOR ITEM = AREA COMPONENT }= \\ \text { IN RANGE } & 0 \text { TO } & \text { O STEP } \\ & & 1\end{array}$

0 AREAS IOF O DEFINED) SELECTED BY ASEL COMMAND.

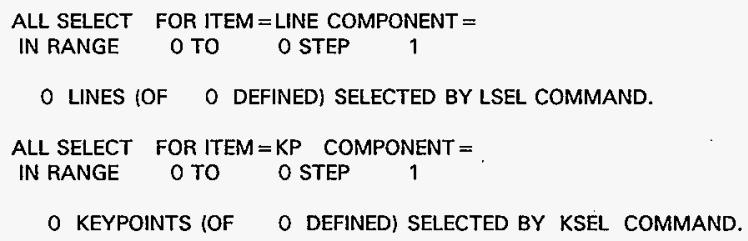

ALL SELECT FOR ITEM = ELEM COMPONENT = 
HNF-SD-TWR-CN-002

Rev. 0

Appendix A

IN RANGE $\uparrow$ TO 681 STEP 1

681 ELEMENTS (OF 681 DEFINED) SELECTED BY ESEL COMMAND.

ALL SELECT FOR ITEM $=$ NODE COMPONENT $=$ IN RANGE 1 TO 30579 STEP

875 NODES (OF 875 DEFINED) SELECTED BY NSEL COMMAND.

PREP7:

ALL CURRENT ANSYS DATA WRITTEN TO FILE NAME $=$ file. $d b$ FOR POSSIBLE RESUME FROM THIS POINT

PREP7:

**** ROUTINE COMPLETED **** CP $=\quad 9.470$

BEGIN:

ANSYS SOLUTION ROUTINE

SOLU_LS1:

PERFORM A TRANSIENT ANALYSIS

THIS WILL BE A.NEW ANALYSIS

SOLU LS1:

STEP BOUNDARY CONDITION KEY $=1$

SOLU LS1:

$A C E L=0.00000 E+000.00000 E+00386.40$

SOLU_LS1:

SPECIFIED CONSTRAINT UZ FOR SELECTED NODES 24041 TO $24041 \mathrm{BY} \quad 1$

REAL $=0.000000000 E+00 \quad$ IMAG $=0.000000000 E+00$

SOLU_LS1:

DO NOT INCLUDE TRANSIENT EFFECTS FOR ALL DOFS THIS LOAD STEP

SOLU_LS1:

$\mathrm{TIME}=0.10000 \mathrm{E}-04$ 
SOLU_LS1:

USE 2 SUBSTEP(S) THIS LOAD STEP FOR ALL DOFS

SOLU_LS1:

USE A MAXIMUM OF 40 EOUILIBRIUM ITERATIONS EACH SUBSTEP SOLU_LS1:

WRITE ANSYS LOADS DATA AS FILE $=$ file. $\$ 01$

SOLU_LS1:

INCLUDE.TRANSIENT EFFECTS FOR ALL DOFS THIS LOAD STEP

SOLU_LS1:

$\mathrm{TIME}=1.9300$

SOLU_LS1:

USE 1000 SUBSTEP(S) THIS LOAD STEP FOR ALL DOFS

SOLU_LS1:

WRITE ALL ITEMS TO THE DATABASE WITH A FREOUENCY OF 5 FOR ALL APPLICABLE ENTITIES

SOLU_LS1:

USE AUTOMATIC TIME STEPPING THIS LOAD STEP

SOLU_LS1:

DELETE SPECIFIED CONSTRAINT UZ FOR SELECTED NODES

RANGE 24041 TO $24041 \mathrm{BY} 1$

NUMBER OF SPECIFIED CONSTRAINTS DELETED $=\quad 1$

SOLU_LS1:

WRITE ANSYS LOADS DATA AS FILE $=$ file. $\mathrm{SO} 2$

SOLU_LS1:

TIME $=1.9900$

SOLU_LS1: 
USE 600 SUBSTEP(S) THIS LOAD STEP FOR ALL DOFS

SOLU_LS1:

WRITE ALL ITEMS TO THE DATABASE WITH A FREQUENCY OF 3 FOR ALL APPLICABLE ENTITIES

SOLU_LS1:

USE A MAXIMUM OF 40 EQUILIBRIUM ITERATIONS EACH SUBSTEP

SOLU LS1:

DO NOT USE AUTOMATIC TIME STEPPING THIS LOAD STEP

SOLU_LS1:

WRITE ANSYS LOADS DATA AS FILE $=$ file. .503

SOLU LS1:

ANSYS REVISION $5.2 \quad 11: 38: 21 \quad 08 / 25 / 1997$

PRINTOUT RESUMED BY /GOP

Load step file number 1 . Begin solution ...

*... ANSYS SOLVE COMMAND ****

*** WARNING ** $\quad \mathrm{CP}=11.180$ TIME $=11: 38: 26$

Real constant 11 referenced by at least element types 2 and 4 .

\#WARNING *. $\quad C P=11.550 \quad$ TIME $=11: 38: 27$

Nodes $I$ and $J$ of element 551 ( COMBIN14) are not coincident.

*** WARNING *** CP $=11.550$ TIME $=11: 38: 27$

Nodes $I$ and $J$ of element 552 (COMBIN14) are not coincident.

*** WARNING *** CP $=11.560 \quad$ TIME $=11: 38: 27$

Nodes $I$ and $J$ of element 553 (COMBIN14) are not coincident.

*** WARNING *** CP $=11.560$ TIME $=11: 38: 27$

Nodes $I$ and $J$ of element 554 ( COMBIN14) are not coincident.

** * WARNING *** CP $=11.600$ TIME $=11: 38: 27$

Nodes I and $\mathrm{J}$ of element 664 ( COMBIN40) are not coincident.

*** WARNING *** CP= 11.600 TIME $=11: 38: 27$

Nodes I and $\mathrm{J}$ of element 665 ( COMBIN 40 ) are not coincident.

** * WARNING ** * CP= 11.600 TIME $=11: 38: 27$

Nodes $($ and $J$ of element $666($ COMBIN40 $)$ are not coincident. 
*** WARNING ***

$\mathrm{CP}=11.600 \quad$ TIME $=11: 38: 27$

Nodes $($ and $\mathrm{J}$ of element 667 ( COMBIN40 ) are not coincident.

*** WARNING *** CP= $11.600 \quad$ TIME $=11: 38: 27$

Nodes $\mathrm{l}$ and $\mathrm{J}$ of element 668 ( COMBIN40) are not coincident.

*** WARNING ***

$C P=11,600 \quad$ TIME $=11: 38: 27$

Nodes $I$ and $J$ of element 669 (COMBIN40) are not coincident.

** * WARNING *** CP $\quad$ C $\quad 11.610$ TIME $=11: 38: 27$

Nodes $I$ and $J$ of element 670 ( COMBIN40 / are not coincident.

*** WARNING *** CP= $\quad 11.610$ TIME $=11: 38: 27$

Nodes $($ and $J$ of element 671 ( COMBIN40) are not coincident.

*** WARNING ** * CP= 11.610 TIME $=11: 38: 27$

Nodes $I$ and $J$ of element 672 (COMBIN40) are not coincident.

** * WARNING *** CP= 11.610 TIME $=11: 38: 27$

Nodes $\mathrm{I}$ and $\mathrm{J}$ of element 673 (COMBIN40) are not coincident.

*** WARNING *** CP= 11.610 TIME $=11: 38: 27$

Nodes $($ and $J$ of element 674 (COMBIN40) are not coincident.

*** WARNING *** CP= $\quad 11.610$ TIME $=11: 38: 27$

Nodes $I$ and $J$ of element 675 (COMBIN40) are not coincident.

*** WARNING *** CP= 11.610 TIME $=11: 38: 27$

Nodes $I$ and $J$ of element 676 (COMBIN40) are not coincident.

*** WARNING * * *

$\mathrm{CP}=11.620 \quad$ TIME $=11: 38: 27$

Nodes $I$ and $J$ of element 677 (COMBIN40) are not coincident.

*** WARNING *** CP= $\quad 11.620$ TIME $=11: 38: 27$

Nodes $($ and $J$ of element 678 (COMBIN4O) are not coincident.

Error messages discontinued after 20 messages were displayed.

More may exist. See (file.err ) for suppressed messages.

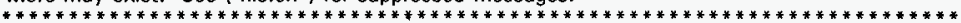

*** NOTE *** CP= 11.620 TIME $=11: 38: 27$

The model data was checked and warning messages were found.

Please review output or errors file (file.err) for these warning

messages.

$$
\text { SOLUTION OPTIONS }
$$

PROBLEM DIMENSIONALITY. . . . . . . . . 3-D

DEGREES OF FREEDOM. . . . . U UX UY UZ ROTX ROTY ROTZ

ANALYSIS TYPE ............. TRANSIENT

SOLUTION METHOD. .............FULL 
PLASTIC MATERIAL PROPERTIES INCLUDED. . . . . YES

NEWTON-RAPHSON OPTION . . . . . . . PROGRAM CHOSEN

*.. NOTE ***

$\mathrm{CP}=11.760 \quad$ TIME $=11: 38: 28$

This load step will be a static (steady-state) step.

*** NOTE ***

$\mathrm{CP}=11.920 \quad \mathrm{TIME}=11: 38: 28$

The step data was checked and warning messages were found.

Please review output or errors file ( file.err ) for these warning messages.

** NOTE * * CP= 11.920 TIME $=11: 38: 28$

Results printout suppressed for interactive execute.

** NOTE *** CP= 11.920 TIME $=11: 38: 28$

Nonlinear analysis, NROPT set to 1 (full Newton-Raphson solution

procedure) for ALL DOFs.

- Reordering still in progress **

* Reordering still in progress **

- Reordering still in progress **

\section{LOAD STEP OPTIONS}

LOAD STEP NUMBER. . . . . . . . . 1

TIME AT END OF THE LOAD STEP. . . . . . . 0.10000 -0 4

NUMBER OF SUBSTEPS. . . . . . . . 2

MAXIMUM NUMBER OF EOUILIBRIUM ITERATIONS. . . . 40

STEP CHANGE BOUNDARY CONDITIONS ....... YES

TRANSIENT (INERTIA) EFFECTS . . . . . . . O OFF

TERMINATE ANALYSIS IF NOT CONVERGED . . . . . YES (EXIT)

CONVERGENCE CONTROLS. . . . . . . . . USE DEFAULTS

INERTIA LOADS $\quad X \quad Y \quad Z$

ACEL . . . . . . 0.00000E +00 0.00000E + $00 \quad 386.40$

COPY INTEGRATION POINT VALUES TO NODE . . . . . YES, FOR ELEMENTS WITH

ACTIVE MAT. NONLINEARITIES

PRINT OUTPUT CONTROLS . . . . . . . . . NO PRINTOUT

DATABASE OUTPUT CONTROLS

ITEM FREQUENCY COMPONENT

ALL 5 .

ALL $\quad 3$

Element Formation Element $=270 \mathrm{Cum}$. Iter. $=1 \mathrm{CP}=19.980$

Time $=0.50000 \mathrm{E}-05$ Load Step $=1$ Substep $=1$ Equilibrium Iteration $=1$.

Element Formation Element $=640 \mathrm{Cum}$. Iter. $=1 \mathrm{CP}=28.530$

Time $=0.50000$ E-05 Load Step $=1$ Substep $=1$ Equilibrium Iteration $=1$.

**** CENTROID, MASS, AND MASS MOMENTS OF INERTIA

CALCULATIONS ASSUME ELEMENT MASS AT ELEMENT CENTROID 
HNF-SD-TWR-CN-002

Rev. 0

Appendix A

TOTAL MASS $=29.185$

\section{CENTROID}

$X C=54.419$

$\mathrm{YC}=-12.839$

$Z C=425.98$
MOM. OF INERTIA ABOUT ORIGIN
MOM. OF INERTIA ABOUT CENTROID

$\mathrm{IXX}=0.3926 \mathrm{E}+07$

$\mathrm{IVY}=0.3969 \mathrm{E}+07$

$\mathrm{IZZ}=0.6220 \mathrm{E}+05$

$I X Y=0.1117 E+05 \quad I X Y=-9218$.

$I Y Z=-528.4 \quad I Y Z=-0.1601 E+06$

$I Z X=-0.8896 E+06 \quad I Z X=-0.2130 E+06$

\section{* * MASS SUMMARY BY ELEMENT TYPE * *}

TYPE MASS

$1 \quad 12.3630$

$4 \quad 16.8219$

Range of element maximum matrix coefficients in global coordinates Maximum $=4.166712683 E+10$ at element 649 .

Minimum $=10$ at element 552 .

\section{* * * ELEMENT MATRIX FORMULATION TIMES}

TYPE NUMBER ENAME TOTAL CP AVE CP

$\begin{array}{ccccc}1 & 630 & \text { SHELL43 } & 16.610 & 0.026 \\ 2 & 29 & \text { CONTAC52 } & 0.040 & 0.001 \\ 3 & 17 \text { COMBIN40 } & 0.010 & 0.001 \\ 4 & 1 & \text { COMBIN40 } & 0.000 & 0.000 \\ 5 & 2 & \text { COMBIN14 } & 0.060 & 0.030 \\ 6 & 2 & \text { COMBIN14 } & 0.000 & 0.000\end{array}$

Time at end of element matrix formulation $\mathrm{CP}=29.5$.

FORCE CONVERGENCE VALUE $=263.1 \quad$ CRITERION $=0.2631$

MOMENT CONVERGENCE VALUE $=0.0000 E+00$ CRITERION $=0.1000 E-02$

Estimated number of active DOF $=4056$.

Maximum wavefront $=171$.

Equation Solution Element $=380 \mathrm{Cum}$. Iter. $=1 \mathrm{CP}=32.970$

Time $=0.50000 \mathrm{E}-05$ Load Step $=1$ Substep $=1$ Equilibrium Iteration $=1$.

F Convergence Norm $=263.05$ Previous Norm $=263.05$

Time at end of matrix triangularization $\mathrm{CP}=34.9099998$.

Equation solver maximum pivot $=1.097381962 \mathrm{E}+11$ at node 21157 ROTX.

Equation solver minimum pivot $=19.9999072$ at node $4583 \mathrm{UX}$.

EQUIL ITER 1 COMPLETED. NEW TRIANG MATRIX. MAX DOF INC $=-0.1862 \mathrm{E}-01$

Element Formation Element $=110 \mathrm{Cum}$. Iter. $=2 \mathrm{CP}=38.530$

Time $=0.50000 E-05$ Load Step $=1$ Substep $=1$ Equilibrium Iteration $=2$.

F Convergence Norm $=263.05$ Previous Norm $=263.05$

Element Formation Element $=320 \mathrm{Cum}$. Iter. $=2 \mathrm{CP}=44.800$

Time $=0.50000$ E-05 Load Step $=1$ Substep $=1$ Equilibrium Iteration $=2$.

F Convergence Norm $=263.05$ Previous Norm $=263.05$ 
Element Formation Element $=560$ Cum, Iter. $=2 \mathrm{CP}=50.810$

Time $=0.50000 \mathrm{E}-05$ Load Step $=1$ Substep $=1$ Equilibrium Iteration $=2$.

$F$ Convergence Norm $=263.05$ Previous Norm $=263.05$

FORCE CONVERGENCE VALUE $=622.8 \quad$ CRITERION $=2.897$

MOMENT CONVERGENCE VALUE $=0.1465$ E-06 CRITERION $=24.83 \quad<<<$ CONVERGED

- RESIDUAL INCREASED. PREV SOLN REMOVED. DESCENT PARAM SET TO 1.000

Element Formation Element $=100 \mathrm{Cum}$. Iter. $=2 \mathrm{CP}=57.810$

Time $=0.50000 \mathrm{E}-05$ Load Step $=1$ Substep $=1$ Equilibrium Iteration $=2$.

$F$ Convergence Norm $=263.05$ Previous Norm $=263.05$

$M$ Convergence Norm $=0.14652 \mathrm{E}-06$ Previous Norm $=0.00000 \mathrm{E}+00$

Element Formation Element $=400 \mathrm{Cum}$. Iter, $=2 \mathrm{CP}=65.810$

Time $=0.50000 \mathrm{E}-05$ Load Step $=1$ Substep $=1$ Equilibrium Iteration $=2$.

F Convergence Norm $=263.05$ Previous Norm $=263.05$

$M$ Convergence Norm $=0.14652 E-06$ Previous Norm $=0.00000 E+00$

FORCE CONVERGENCE VALUE $=263.1 \quad$ CRITERION $=0.2631$

MOMENT CONVERGENCE VALUE $=0.0000 E+00$ CRITERION $=0.1000 E-02$

Equation Solution Element $=90 \mathrm{Cum}$. Iter. $=2 \mathrm{CP}=73.980$

Time $=0.50000 \mathrm{E}-05$ Load Step $=1$ Substep $=1$ Equilibrium Iteration $=2$.

F Convergence Norm $=263.05$ Previous Norm $=263.05$

M Convergence Norm $=0.00000 E+00$ Previous Norm $=0.14652 \mathrm{E}-06$

EQUIL ITER 2 COMPLETED. NEW TRIANG MATRIX. MAX DOF INC $=-0.1863 E-01$

Element Formation Element $=150 \mathrm{Cum}$. Iter. $=3 \mathrm{CP}=82.260$

Time $=0.50000$ E-05 Load Step $=1$ Substep $=1$ Equilibrium Iteration $=3$.

F Convergence Norm $=263.05$ Previous Norm $=263.05$

$M$ Convergence Norm $=0.00000 E+00$ Previous Norm $=0.14652 \mathrm{E}-06$

Element Formation Element $=290 \mathrm{Cum}$. Iter. $=3 \mathrm{CP}=86.320$

Time $=0.50000$ E-05 Load Step $=1$ Substep $=1$ Equilibrium Iteration $=3$.

F Convergence Norm $=263.05$ Previous Norm $=263.05$

$M$ Convergence Norm $=0.00000 E+00$ Previous Norm $=0.14652 E-06$

Element Formation Element $=300$ Cum. Iter. $=3 \mathrm{CP}=86.690$

Time $=0.50000 \mathrm{E}-05$ Load Step $=1$ Substep $=1$ Equilibrium Iteration $=3$.

F Convergence Norm $=263.05$ Previous Norm $=263.05$

M Convergence Norm $=0.00000 E+00$ Previous Norm $=0.14652 E-06$

Element Formation Element $=590 \mathrm{Cum}$, Iter. $=3 \mathrm{CP}=93.970$

Time $=0.50000 \mathrm{E}-05$ Load Step $=1$ Substep $=1$ Equilibrium Iteration $=3$.

F Convergence Norm $=263.05$ Previous Norm $=263.05$

$M$ Convergence Norm $=0.00000 E+00$ Previous Norm $=0.14652 E-06$

FORCE CONVERGENCE VALUE $=126.1 \quad$ CRITERION $=2.910$

MOMENT CONVERGENCE VALUE $=0.1364$ E-06 CRITERION $=24.84 \quad<<$ CONVERGED

Equation Solution Element $=550 \mathrm{Cum}$. Iter. $=3 \mathrm{CP}=100.970$

Time $=0.50000 \mathrm{E}-05$ Load Step $=1$ Substep $=1$ Equilibrium Iteration $=3$.

F Convergence Norm $=126.12$ Previous Norm $=263.05$

$M$ Convergence Norm $=0.13644 \mathrm{E}-06$ Previous Norm $=0.00000 E+00$

EQUIL ITER 3 COMPLETED. NEW TRIANG MATRIX. MAX DOF INC $=0.3859 E-05$

Element Formation Element $=230 \mathrm{Cum}$. Iter $=4 \mathrm{CP}=108.660$

Time $=0.50000 \mathrm{E}-05$ Load Step $=1$ Substep $=1$ Equilibrium Iteration $=4$.

F Convergence Norm $=126.12$ Previous Norm $=263.05$

$M$ Convergence Norm $=0.13644 \mathrm{E}-06$ Previous Norm $=0.00000 \mathrm{E}+00$

Element Formation Element $=550 \mathrm{Cum}$. Iter. $=4 \mathrm{CP}=116.950$

Time $=0.50000 \mathrm{E}-05$ Load Step $=1$ Substep $=1$ Equilibrium Iteration $=4$.

$\mathrm{F}$ Convergence Norm $=126.12$ Previous Norm $=263.05$

$\mathrm{M}$ Convergence Norm $=0.13644 \mathrm{E}-06$ Previous Norm $=0.00000 \mathrm{E}+00$ 
HNF-SD-TWR-CN-002

Rev. 0

Appendix A

FORCE CONVERGENCE VALUE $=112.5 \quad$ CRITERION $=2.910$
MOMENT CONVERGENCE VALUE $=0.1424$ E-10 CRITERION $=24.83 \quad<<<$ CONVERGED

Equation Solution Element $=560$ Cum. Iter. $=4 \mathrm{CP}=124.940$

Time $=0.50000 \mathrm{E}-05$ Load Step $=1$ Substep $=1$ Equilibrium Iteration $=4$.

$F$ Convergence Norm $=112.49 \quad$ Previous Norm $=126.12$

$M$ Convergence Norm $=0.14238 \mathrm{E}-10$ Previous Norm $=0.13644 \mathrm{E}-06$

EQUIL ITER 4 COMPLETED. NEW TRIANG MATRIX. MAX DOF INC $=0.3948 E-05$

Element Formation Element $=130 \mathrm{Cum}$. Iter. $=5 \mathrm{CP}=129.750$

Time $=0.50000 \mathrm{E}-05$ Load Step $=1$ Substep $=1$ Equilibrium Iteration $=5$.

$F$ Convergence Norm $=112.49 \quad$ Previous Norm $=126.12$

$M$ Convergence Norm $=0.14238 \mathrm{E}-10$ Previous Norm $=0.13644 \mathrm{E}-06$

Element Formation Element $=140 \mathrm{Cum}$. Iter. $=5 \mathrm{CP}=130.080$

Time $=0.50000 \mathrm{E}-05$ Load Step $=1$ Substep $=1$ Equilibrium Iteration $=5$.

$F$ Convergence Norm $=112.49 \quad$ Previous Norm $=126.12$

$M$ Convergence Norm $=0.14238 \mathrm{E}-10$ Previous Norm $=0.13644 \mathrm{E}-06$

Element Formation Element $=390 \mathrm{Cum}$. Iter. $=5 \mathrm{CP}=137.190$

Time $=0.50000 \mathrm{E}-05$ Load Step $=1$ Substep $=1$ Equilibrium Iteration $=5$.

F Convergence Norm $=112.49$ Previous Norm $=126.12$

$M$ Convergence Norm $=0.14238 \mathrm{E}-10$ Previous Norm $=0.13644 \mathrm{E}-06$

Solution Preparation Element $=10 \mathrm{Cum}$. Iter. $=5 \mathrm{CP}=144.410$

Time $=0.50000 \mathrm{E}-05$ Load Step $=1$ Substep $=1$ Equilibrium Iteration $=5$.

$\mathrm{F}$ Convergence Norm $=112.49$.Previous Norm $=126.12$

$M$ Convergence Norm $=0.14238 \mathrm{E}-10$ Previous Norm $=0.13644 \mathrm{E}-06$

FORCE CONVERGENCE VALUE $=104.2 \quad$ CRITERION $=2.911$

MOMENT CONVERGENCE VALUE $=0.1581 \mathrm{E}-10$ CRITERION $=24.82<<$ CONVERGED

RESIDUAL DECREASED. DESCENT PARAMETER SET TO 0.2500

EOUIL ITER 5 COMPLETED. NEW TRIANG MATRIX. MAX DOF INC $=0.3997 \mathrm{E}-05$

Element Formation Element $=60$ Cum. Iter. $=6 \mathrm{CP}=151.830$

Time $=0.50000 \mathrm{E}-05$ Load Step $=1$ Substep $=1$ Equilibrium Iteration $=6$.

$F$ Convergence Norm $=104.16$ Previous Norm $=112.49$

$\mathrm{M}$ Convergence Norm $=0.15811 \mathrm{E}-10$ Previous Norm $=0.14238 \mathrm{E}-10$

Element Formation Element $=340$ Cum. Iter. $=6 \mathrm{CP}=159.880$

Time $=0.50000 \mathrm{E}-05$ Load Step $=1$ Substep $=1$ Equilibrium Iteration $=6$.

$F$ Convergence Norm $=104.16 \quad$ Previous Norm $=112.49$

$M$ Convergence Norm $=0.15811 \mathrm{E}-10$ Previous Norm $=0.14238 \mathrm{E}-10$

Element Formation Element $=670$ Cum. Iter. $=6 \mathrm{CP}=167.940$

Time $=0.50000 \mathrm{E}-05$ Load Step $=1$ Substep $=1$ Equilibrium Iteration $=6$.

F Convergence Norm $=104.16 \quad$ Previous Norm $=112.49$

$M$ Convergence Norm $=0.15811 \mathrm{E}-10$ Previous Norm $=0.14238 \mathrm{E}-10$

FORCE CONVERGENCE VALUE $=98.73$ CRITERION $=2.911$

MOMENT CONVERGENCE VALUE $=0.1258 E-10$ CRITERION $=24.81<<<$ CONVERGED

RESIDUAL DECREASED. DESCENT PARAMETER SET TO $0.6250 E-01$.

EQUIL. ITER 6 COMPLETED. NEW TRIANG MATRIX. MAX DOF INC $=0.1545 E-04$

Element Formation Element $=110$ Cum. Iter. $=7 \mathrm{CP}=177.020$

Time $=0.50000$ E-05 Load Step $=1$ Substep $=1$ Equilibrium Iteration $=7$.

$F$ Convergence Norm $=98.731$ Previous Norm $=104.16$

$M$ Convergence Norm $=0.12575 E-10$ Previous Norm $=0.15811 \mathrm{E}-10$

Element Formation Element $=490$ Cum. Iter. $=7 \mathrm{CP}=187.270$

Time $=0.50000 \mathrm{E}-05$ Load Step $=1$ Substep $=1$ Equilibrium Iteration $=7$. F Convergence Norm $=98.731$ Previous Norm $=104.16$

$M$ Convergence Norm $=0.12575 \mathrm{E}-10$ Previous Norm $=0.15811 \mathrm{E}-10$

Solution Preparation Element $=10 \mathrm{Cum}$. Iter. $=7 \mathrm{CP}=192.110$ 
HNF-SD-TWR-CN-002

Rev. 0

Appendix A

Time $=0.50000 E-05$ Load Step $=1$ Substep $=1$ Equilibrium Iteration $=7$.

$F$ Convergence Norm $=98.731 \quad$ Previous Norm $=104.16$

$M$ Convergence Norm $=0.12575 \mathrm{E}-10$ Previous Norm $=0.15811 \mathrm{E}-10$

FORCE CONVERGENCE VALUE $=88.08 \quad$ CRITERION $=2.912$

MOMENT CONVERGENCE VALUE $=0.3335 E-10$ CRITERION $=24.79<<<$ CONVERGED

RESIDUAL DECREASED. DESCENT PARAMETER SET TO $0.1562 E-01$

Equation Solution Element $=660 \mathrm{Cum}$. Iter $=7 \mathrm{CP}=197.410$

Time $=0.50000 \mathrm{E}-05$ Load Step $=1$ Substep $=1$ Equilibrium Iteration $=7$.

$F$ Convergence Norm $=88.084 \quad$ Previous Norm $=98.731$

$M$ Convergence Norm $=0.33354 \mathrm{E}-10$ Previous Norm $=0.12575 \mathrm{E}-10$

EQUIL ITER 7 COMPLETED. NEW TRIANG MATRIX. MAX DOF INC $=0.4885 \mathrm{E}-04$

Element Formation Element $=230$ Cum. Iter $=8 \mathrm{CP}=204.660$

Time $=0.50000 \mathrm{E}-05$ Load Step $=1$ Substep $=1$ Equilibrium Iteration $=8$.

F Convergence Norm $=88.084 \quad$ Previous Norm $=98.731$

$M$ Convergence Norm $=0.33354 \mathrm{E}-10$ Previous Norm $=0.12575 \mathrm{E}-10$

Element Formation Element $=510$ Cum. Iter. $=8 \mathrm{CP}=212.020$

Time $=0.50000 \mathrm{E}-05$ Load Step $=1$ Substep $=1$ Equilibrium Iteration $=8$.

F Convergence Norm $=88.084 \quad$ Previous Norm $=98.731$

$M$ Convergence Norm $=0.33354 \mathrm{E}-10$ Previous Norm $=0.12575 \mathrm{E}-10$

FORCE CONVERGENCE VALUE $=67.87$ CRITERION $=2.917$

MOMENT CONVERGENCE VALUE $=0.8210 E-10$ CRITERION $=24.72<<<$ CONVERGED

RESIDUAL, DECREASED. DESCENT PARAMETER SET TO $0.0000 E+00$

Equation Solution Element $=450 \mathrm{Cum}$. Iter. $=8 \mathrm{CP}=220.090$

Time $=0.50000 \mathrm{E}-05$ Load Step $=1$ Substep $=1$ Equilibrium Iteration $=8$.

F Convergence Norm $=67.867 \quad$ Previous Norm $=88.084$

$M$ Convergence Norm $=0.82095 \mathrm{E}-10$ Previous Norm $=0.33354 \mathrm{E}-10$

EQUIL ITER 8 COMPLETED. NEW TRIANG MATRIX. MAX DOF INC $=0.9432 E-04$

Element Formation Element $=200 \mathrm{Cum}$. Iter. $=9 \mathrm{CP}=227.630$

Time $=0.50000 \mathrm{E}-05$ Load Step $=1$ Stubstep $=1$ Equilibrium Iteration $=9$.

$F$ Convergence Norm $=67.867$ Previous Norm $=88.084$

$M$ Convergence Norm $=0.82095 \mathrm{E}-10$ Previous Norm $=0.33354 \mathrm{E}-10$

Element Formation Element $=560 \mathrm{Cum}$. Iter $=9 \mathrm{CP}=236.990$

Time $=0.50000 \mathrm{E}-05$ Load Step $=1$ Substep $=1$ Equilibrium Iteration $=9$.

F Convergence Norm $=67.867$ Previous Norm $=88.084$

$M$ Convergence Norm $=0.82095 \mathrm{E}-10$ Previous Norm $=0.33354 \mathrm{E}-10$

FORCE CONVERGENCE VALUE $=114.5$ CRITERION $=2.925$

MOMENT CONVERGENCE VALUE $=0.1445 E-09$ CRITERION $=24.59<<<$ CONVERGED

- RESIDUAL INCREASED. PREV SOLN REMOVED. DESCENT PARAM SET TO 1.000

Element Formation Element $=10 \mathrm{Cum} \cdot$ Iter. $=9 \mathrm{CP}=241.520$

Time $=0.50000 E-05$ Load Step $=1$ Substep $=1$ Equilibrium Iteration $=9$. F Convergence Norm $=67.867$ Previous Norm $=88.084$

$M$ Convergence Norm $=0.14448 \mathrm{E}-09$ Previous Norm $=0.82095 \mathrm{E}-10$

Element Formation Element $=290$ Cum. Iter. $=9 \mathrm{CP}=249.680$

Time $=0.50000$ E-05 Load Step $=1$ Substep $=1$ Equilibrium Iteration $=9$. $F$ Convergence Norm $=67.867$ Previous Norm $=88.084$

$M$ Convergence Norm $=0.14448 E-09$ Previous Norm $=0.82095 \mathrm{E}-10$

Element Formation Element $=610$ Cum. Iter. $=9 \mathrm{CP}=257.820$

Time $=0.50000$ E-05 Load Step $=1$ Substep $=1$ Equilibrium Iteration $=9$. $F$ Convergence Norm $=67.867$ Previous Norm $=88.084$

$M$ Convergence Norm $=0.14448 E-09$ Previous Norm $=0.82095 \mathrm{E}-10$

FORCE CONVERGENCE VALUE $=67.87 \quad$ CRITERION $=2.917$

MOMENT CONVERGENCE VALUE $=0.8207 E-10 \quad$ CRITERION $=24.72$ 
HNF-SD-TWR-CN-002

Rev. 0

Appendix A

Equation Solution Element $=400$ Cum. Iter. $=9 \mathrm{CP}=263.160$

Time $=0.50000 \mathrm{E}-05$ Load Step $=1$ Substep $=1$ Equilibrium Iteration $=9$.

F Convergence Norm $=67.867$ Previous Norm $=67.867$

$M$ Convergence Norm $=0.82066 \mathrm{E}-10$ Previous Norm $=0.14448 \mathrm{E}-09$

EOUIL ITER 9 COMPLETED. NEW TRIANG MATRIX. MAX DOF INC $=0.3002 \mathrm{E}-05$

Element Formation Element $=180 \mathrm{Cum}$. Iter $=10 \mathrm{CP}=270.480$

Time $=0.50000 \mathrm{E}-05$ Load Step $=1$ Substep $=1$ Equilibrium Iteration $=10$.

$\mathrm{F}$ Convergence Norm $=67.867$ Previous Norm $=67.867$

$M$ Convergence Norm $=0.82066 \mathrm{E}-10$ Previous Norm $=0.14448 \mathrm{E}-09$

Element Formation Element $=500 \mathrm{Cum}$. Iter. $=10 \mathrm{CP}=278.920$

Time $=0.50000$ E-05 Load Step $=1$ Substep $=1$ Equilibrium Iteration $=10$.

F Convergence Norm $=67.867$ Previous Norm $=67.867$

$M$ Convergence Norm $=0.82066 \mathrm{E}-10$ Previous Norm $=0.14448 \mathrm{E}-09$

FORCE CONVERGENCE VALUE $=66.71 \quad$ CRITERION $=2.917$

MOMENT CONVERGENCE VALUE $=0.9361 \mathrm{E}-11$ CRITERION $=24.71<<<$ CONVERGED

Equation Solution Element $=400 \mathrm{Cum}$. Iter. $=10 \mathrm{CP}=286.830$

Time $=0.50000 \mathrm{E}-05$ Load Step $=1$ Substep $=1$ Equilibrium Iteration $=10$.

$\mathrm{F}$ Convergence Norm $=66: 706$ Previous Norm $=67.867$

$M$ Convergence Norm $=0.93612 \mathrm{E}-11$ Previous Norm $=0.82066 \mathrm{E}-10$

EQUIL ITER 10 COMPLETED. NEW TRIANG MATRIX. MAX DOF INC $=0.2952 \mathrm{E}-05$

Element Formation Element $=220$ Cum. Iter. $=11 \mathrm{CP}=295.260$

Time $=0.50000 \mathrm{E}-05$ Load Step $=1$ Substep $=1$ Equilibrium Iteration $=11$.

$F$ Convergence Norm $=66.706$ Previous Norm $=67.867$

$M$ Convergence Norm $=0.93612 \mathrm{E}-11$ Previous Norm $=0.82066 \mathrm{E}-10$

Element Formation Element $=230$ Cum. Iter. $=11 \mathrm{CP}=295.570$

Time $=0.50000 E-05$ Load Step $=1$ Substep $=1$ Equilibrium Iteration $=11$.

F Convergence Norm $=66.706$ Previous Norm $=67.867$

$M$ Convergence Norm $=0.93612 \mathrm{E}-11$ Previous Norm $=0.82066 \mathrm{E}-10$

Element Formation Element $=430 \mathrm{Cum}$. Iter. $=11 \mathrm{CP}=301.100$

Time $=0.50000 \mathrm{E}-05$ Load Step $=1$ Substep $=1$ Equilibrium Iteration $=11$.

$\mathrm{F}$ Convergence Norm $=66.706$ Previous Norm $=67.867$

$M$ Convergence Norm $=0.93612 \mathrm{E}-11$ Previous Norm $=0.82066 \mathrm{E}-10$

Solution Preparation Element $=280 \mathrm{Cum}$. Iter. $=11 \mathrm{CP}=307.890$

Time $=0.50000 E-05$ Load Step $=1$ Substep $=1$ Equilibrium Iteration $=11$.

$\mathrm{F}$ Convergence Norm $=66.706$ Previous Norm $=67.867$

$\mathrm{M}$ Convergence Norm $=0.93612 \mathrm{E}-11$ Previous Norm $=0.82066 \mathrm{E}-10$

FORCE CONVERGENCE VALUE $=65.58 \quad$ CRITERION $=2.917$

MOMENT CONVERGENCE VALUE $=0.8672 E-11$ CRITERION $=24.71<<<$ CONVERGED

EQUIL ITER 11 COMPLETED. NEW TRIANG MATRIX. MAX DOF INC $=0.2901 \mathrm{E}-05$

Element Formation Element $=90 \mathrm{Cum}$. Iter. $=12 \mathrm{CP}=315.650$

Time $=0.50000 E-05$ Load Step $=1$ Substep $=1$ Equilibrium Iteration $=12$.

$F$ Convergence Norm $=65.579$ Previous Norm $=66.706$

$M$ Convergence Norm $=0.86717 \mathrm{E}-11$ Previous Norm $=0.93612 \mathrm{E}-11$

Element Formation Element $=370 \mathrm{Cum}$. Iter. $=12 \mathrm{CP}=323.640$

Time $=0.50000$ E-05 Load Step $=1$ Substep $=1$ Equilibrium Iteration $=12$.

F Convergence Norm $=65.579$ Previous Norm $=66.706$

$M$ Convergence Norm $=0.86717 \mathrm{E}-11$ Previous Norm $=0.93612 \mathrm{E}-11$

Solution Preparation Element $=330 \mathrm{Cum}$. Iter. $=12 \mathrm{CP}=331.750$

Time $=0.50000 \mathrm{E}-05$ Load Step $=1$ Substep $=1$ Equilibrium Iteration $=12$.

F Convergence Norm $=65.579$ Previous Norm $=66.706$

$M$ Convergence Norm $=0.86717 \mathrm{E}-11$ Previous Norm $=0.93612 \mathrm{E}-11$

FORCE CONVERGENCE VALUE $=64.48 \quad$ CRITERION $=2.917$ 
MOMENT CONVERGENCE VALUE $=0.9060$ E-11 CRITERION $=24.71 \quad<<<$ CONVERGED RESIDUAL DECREASED. DESCENT PARAMETER SET TO 0.2500 EQUIL ITER 12 COMPLETED. NEW TRIANG MATRIX. MAX DOF INC $=0.2852 E-05$

Element Formation Element $=30 \mathrm{Cum}$. Iter. $=13 \mathrm{CP}=337.540$

Time $=0.50000 \mathrm{E}-05$ Load Step $=1$ Substep $=1$ Equilibrium Iteration $=13$. F Convergence Norm $=64.481$ Previous Norm $=65.579$

M Convergence Norm $=0.90602 \mathrm{E}-11$ Previous Norm $=0.86717 \mathrm{E}-11$

Element Formation Element $=40 \mathrm{Cum}$. Iter. $=13 \mathrm{CP}=337.880$

Time $=0.50000 \mathrm{E}-05$ Load Step $=1$ Substep $=1$ Equilibrium Iteration $=13$. F Convergence Norm $=64.481 \quad$ Previous Norm $=65.579$

$M$ Convergence Norm $=0.90602 \mathrm{E}-11$ Previous Norm $=0.86717 \mathrm{E}-11$

Element Formation Element $=290 \mathrm{Cum}$. Iter $=13 \mathrm{CP}=345.220$

Time $=0.50000 \mathrm{E}-05$ Load Step $=1$ Substep $=1$ Equilibrium Iteration $=13$. $F$ Convergence Norm $=64.481$ Previous Norm $=65.579$

$M$ Convergence Norm $=0.90602 \mathrm{E}-11$ Previous Norm $=0.86717 \mathrm{E}-11$

Element Formation Element $=600$ Cum. Iter. $=13 \mathrm{CP}=353.070$

Time $=0.50000 \mathrm{E}-05$ Load Step $=1$ Substep $=1$ Equilibrium Iteration $=13$. $F$ Convergence Norm $=64.481 \quad$ Previous Norm $=65.579$ $M$ Convergence Norm $=0.90602 \mathrm{E}-11$ Previous Norm $=0.86717 \mathrm{E}-11$ FORCE CONVERGENCE VALUE $=63.41$ CRITERION $=2.918$ MOMENT CONVERGENCE VALUE $=0.8824 E-11$ CRITERION $=24.70<<<$ CONVERGED RESIDUAL DECREASED. DESCENT PARAMETER SET TO $0.6250 E-01$ EQULL ITER 13 COMPLETED. NEW TRIANG MATRIX. MAX DOF INC $=0.1068 E-04$

Element Formation Element $=10 \mathrm{Cum}$. Iter. $=14 \mathrm{CP}=361.050$

Time $=0.50000$ E-05 Load Step $=1$ Substep $=1$ Equilibrium Iteration $=14$. $F$ Convergence Norm $=63.408$ Previous Norm $=64.481$

$M$ Convergence Norm $=0.88237 \mathrm{E}-11$ Previous Norm $=0.90602 \mathrm{E}-11$

Element Formation Element $=290 \mathrm{Cum}$. Iter. $=14 \mathrm{CP}=369.130$

Time $=0.50000$ E-05 Load Step $=1$ Substep $=1$ Equilibrium Iteration $=14$. $F$ Convergence Norm $=63.408$ Previous Norm $=64.481$

$M$ Convergence Norm $=0.88237 \mathrm{E}-11$ Previous Norm $=0.90602 \mathrm{E}-11$

Element Formation Element $=590 \mathrm{Cum}$. Iter. $=14 \mathrm{CP}=376.590$

Time $=0.50000$ E-05 Load Step $=1$ Substep $=1$ Equilibrium Iteration $=14$. F Convergence Norm $=63.408$ Previous Norm $=64.481$

$M$ Convergence Norm $=0.88237 \mathrm{E}-11$ Previous Norm $=0.90602 \mathrm{E}-11$ FORCE CONVERGENCE VALUE $=59.44 \quad$ CRITERION $=2.919$ MOMENT CONVERGENCE VALUE $=0.1758 E-10$ CRITERION $=24.69<<<$ CONVERGED RESIDUAL DECREASED. DESCENT PARAMETER SET TO $0.1562 E-01$

Equation Solution Element $=450 \mathrm{Cum}$. Iter. $=14 \mathrm{CP}=382.670$

Time $=0.50000 \mathrm{E}-05$ Load Step $=1$ Substep $=1$ Equilibrium Iteration $=14$. $F$ Convergence Norm $=59.438$ Previous Norm $=63.408$ $M$ Convergence Norm $=0.17581 \mathrm{E}-10$ Previous Norm $=0.88237 \mathrm{E}-11$ EQUIL ITER 14 COMPLETED. NEW TRIANG MATRIX. MAX DOF INC $=0.3367 E-04$

Element Formation Element $=140 \mathrm{Cum}$. Iter. $=15 \mathrm{CP}=388.490$

Time $=0.50000 \mathrm{E}-05$ Load Step $=1$ Substep $=1$ Equilibrium Iteration $=15$. $F$ Convergence Norm $=59.438$ Previous Norm $=63.408$

$M$ Convergence Norm $=0.17581 \mathrm{E}-10$ Previous Norm $=0.88237 \mathrm{E}-11$

Element Formation Element $=250$ Cum. Iter. $=15 \mathrm{CP}=391.800$

Time $=0.50000$ E- 05 Load Step $=1$ Substep $=1$ Equilibrium Iteration $=15$. $F$ Convergence Norm $=59.438$ Previous Norm $=63.408$

$M$ Convergence Norm $=0.17581 \mathrm{E}-10$ Previous Norm $=0.88237 \mathrm{E}-11$

Element Formation Element $=320 \mathrm{Cum}$. Iter. $=15 \mathrm{CP}=393.920$ 
HNF-SD-TWR-CN-002

Rev. 0

Appendix A

Time $=0.50000 \mathrm{E}-05$ Load Step $=1$ Substep $=1$ Equilibrium Iteration $=15$.

F Convergence Norm $=59.438$ Previous Norm $=63.408$

$M$ Convergence Norm $=0.17581 \mathrm{E}-10$ Previous Norm $=0.88237 \mathrm{E}-11$

Element Formation Element $=640 \mathrm{Cum}$. Iter. $=15 \mathrm{CP}=401.810$

Time $=0.50000 \mathrm{E}-05$ Load Step $=1$ Substep $=1$ Equilibrium Iteration $=15$.

$F$ Convergence Norm $=59.438$ Previous Norm $=63.408$

$M$ Convergence Norm $=0.17581 \mathrm{E}-10$ Previous Norm $=0.88237 \mathrm{E}-11$

FORCE CONVERGENCE VALUE $=46.98 \quad$ CRITERION $=2.922$

MOMENT CONVERGENCE VALUE $=0.4575 E-10$ CRITERION $=24.64 \quad<<<$ CONVERGED

RESIDUAL DECREASED. DESCENT PARAMETER SET TO $0.0000 E+00$

EQUIL ITER 15 COMPLETED. NEW TRIANG MATRIX. MAX DOF INC $=0.6191 \mathrm{E}-04$

Element Formation Element $=10 \mathrm{Cum}$. Iter. $=16 \mathrm{CP}=408.830$

Time $=0.50000$ E -05 Load Step $=1$ Substep $=1$ Equilibrium Iteration $=16$.

F Convergence Norm $=46.979$ Previous Norm $=59.438$

$M$ Convergence Norm $=0.45751 \mathrm{E}-10$ Previous Norm $=0.17581 \mathrm{E}-10$

Element Formation Element $=290 \mathrm{Cum}$. Iter. $=16 \mathrm{CP}=416.990$

Time $=0.50000 \mathrm{E}-05$ Load Step $=1$ Substep $=1$ Equilibrium Iteration $=16$.

$F$ Convergence Norm $=46.979 \quad$ Previous Norm $=59.438$

$M$ Convergence Norm $=0.45751 \mathrm{E}-10$ Previous Norm $=0.17581 \mathrm{E}-10$

Element Formation Element $=630 \mathrm{Cum}$. Iter. $=16 \mathrm{CP}=425.480$

Time $=0.50000 \mathrm{E}-05$ Load Step $=1$ Substep $=1$ Equilibrium Iteration $=16$.

F Convergence Norm $=46.979 \quad$ Previous Norm $=59.438$

$M$ Convergence Norm $=0.45751 \mathrm{E}-10$ Previous Norm $=0.17581 \mathrm{E}-10$

FORCE CONVERGENCE VALUE $=21.46 \quad$ CRITERION $=2.927$

MOMENT CONVERGENCE VALUE $=0.1104 \mathrm{E}-09$ CRITERION $=24.55 \quad<<<$ CONVERGED

EQUIL ITER 16 COMPLETED. NEW TRIANG MATRIX. MAX DOF INC $=0.5255 E-04$

Element Formation Element $=20 \mathrm{Cum}$. Iter. $=17 \mathrm{CP}=432.810$

Time $=0.50000$ E-05 Load Step $=1$ Substep $=1$ Equilibrium Iteration $=17$.

F Convergence Norm $=21.463$ Previous Norm $=46.979$

$M$ Convergence Norm $=0.11037 \mathrm{E}-09$ Previous Norm $=0.45751 \mathrm{E}-10$

Element Formation Element $=160 \mathrm{Cum}$. Iter. $=17 \mathrm{CP}=436.950$

Time $=0.50000 \mathrm{E}-05$ Load Step $=1$ Substep $=1$ Equilibrium Iteration $=17$.

F Convergence Norm $=21.463$ Previous Norm $=46.979$

$M$ Convergence Norm $=0.11037 \mathrm{E}-09$ Previous Norm $=0.45751 \mathrm{E}-10$

Element Formation Element $=190 \mathrm{Cum}$. Iter. $=17 \mathrm{CP}=437.860$

Time $=0.50000$ E-05 Load Step $=1$ Substep $=1$ Equilibrium Iteration $=17$.

$F$ Convergence Norm $=21.463$ Previous Norm $=46.979$

$\mathrm{M}$ Convergence Norm $=0.11037 \mathrm{E}-09$ Previous Norm $=0.45751 \mathrm{E}-10$

Element Formation Element $=270 \mathrm{Cum}$. Iter. $=17 \mathrm{CP}=440.250$

Time $=0.50000$ E-05 Load Step $=1$ Substep $=1$ Equilibrium Iteration $=17$.

$F$ Convergence Norm $=21.463$ Previous Norm $=46.979$

$M$ Convergence Norm $=0.11037 \mathrm{E}-09$ Previous Norm $=0.45751 \mathrm{E}-10$

Element Formation Element $=550 \mathrm{Cum}$. Iter. $=17 \mathrm{CP}=447.410$

Time $=0.50000 E-05$ Load Step $=1$ Substep $=1$ Equilibrium Iteration $=17$.

$F$ Convergence Norm $=21.463$ Previous Norm $=46.979$

$\mathrm{M}$ Convergence Norm $=0.11037 \mathrm{E}-09$ Previous Norm $=0.45751 \mathrm{E}-10$

FORCE CONVERGENCE VALUE $=0.7084 \mathrm{E}-10$ CRITERION $=2.932<<<$ CONVERGED

MOMENT CONVERGENCE VALUE $=0.8789 \mathrm{E}-10$ CRITERION $=24.48<<<$ CONVERGED

$>>>$ SOLUTION CONVERGED AFTER EQUILIBRIUM ITERATION 16

Element Output Element $=70 \mathrm{Cum}$. Iter. $=16 \mathrm{CP}=453.280$

Time $=0.50000 \mathrm{E}-05$ Load Step $=1$ Substep $=1$ Equilibrium Iteration $=16$.

$F$ Convergence Norm $=0.70835 E-10$ Previous Norm $=21.463$ 
HNF-SD-TWR-CN-002

Rev. 0

Appendix A

M Convergence Norm $=0.87886 \mathrm{E}-10$ Previous Norm $=0.11037 \mathrm{E}-09$

\begin{tabular}{|c|c|c|c|c|}
\hline & 630 & SHELL & 9.46 & \\
\hline 2 & 29 & CONTAC52 & 0.040 & 0. \\
\hline 3 & 17 & COMBIN40 & 0.010 & 0. \\
\hline 4 & 1 & COMBIN40 & 0.000 & 0. \\
\hline$=$ & 2 & COMBIN14 & 0.010 & \\
\hline 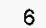 & 2 & COMBIN 14 & 0.010 & \\
\hline
\end{tabular}

** nOdal loAd calculation times

TYPE NUMBER ENAME TOTAL CP AVE CP

$\begin{array}{ccccc}1 & 630 & \text { SHELL43 } & 0.120 & 0.000 \\ 2 & 29 & \text { CONTAC52 } & 0.000 & 0.000 \\ 3 & 17 & \text { COMBIN40 } & 0.000 & 0.000 \\ 4 & 1 & \text { COMBIN40 } & 0.000 & 0.000 \\ 5 & 2 & \text { COMBIN14 } & 0.010 & 0.005 \\ 6 & 2 & \text { COMBIN14 } & 0.000 & 0.000\end{array}$

** LOAD STEP 1 SUBSTEP 1 COMPLETED. CUM ITER $=16$

$\cdots$ TIME $=0.500000$ E-05 TIME INC $=0.500000 \mathrm{E}-05$

Element Formation Element $=10 \mathrm{Cum}$. Iter. $=17 \mathrm{CP}=463.950$

Time $=0.10000 E-04$ Load $S$ tep $=1$ Substep $=2$ Equilibrium Iteration $=1$. F Convergence Norm $=0.70835 \mathrm{E}-10$ Previous Norm $=21.463$

$M$ Convergence Norm $=0.87886 \mathrm{E}-10$ Previous Norm $=0.11037 \mathrm{E}-09$

Element Formation Element $=270 \mathrm{Cum}$. Iter. $=17 \mathrm{CP}=471.440$

Time $=0.10000 \mathrm{E}-04$ Load Step $=1$ Substep $=2$ Equilibrium Iteration $=1$.

$F$ Convergence Norm $=0.70835 E-10$ Previous Norm $=21.463$

$M$ Convergence Norm $=0.87886 \mathrm{E}-10$ Previous Norm $=0.11037 \mathrm{E}-09$

Element Formation Element $=590 \mathrm{Cum}$. Iter. $=17 \mathrm{CP}=479.320$

Time $=0.10000 E-04$ Load Step $=1$ Substep $=2$ Equilibrium Iteration $=1$.

$F$ Convergence Norm $=0.70835 \mathrm{E}-10$ Previous Norm $=21.463$

$M$ Convergence Norm $=0.87886 \mathrm{E}-10$ Previous Norm $=0.11037 \mathrm{E}-09$

FORCE CONVERGENCE VALUE $=0.7084 \mathrm{E}-10$ CRITERION $=2.932$

MOMENT CONVERGENCE VALUE $=0.8789 E-10$ CRITERION $=24.48$

Equation Solution Element $=470 \mathrm{Cum}$. Iter. $=17 \mathrm{CP}=485.620$

Time $=0.10000 \mathrm{E}-04$ Load $\mathrm{Step}=1$ Substep $=2$ Equilibrium Iteration $=1$. $F$ Convergence Norm $=0.70835 E-10$ Previous Norm $=0.70835 E-10$

$M$ Convergence Norm $=0.87886 \mathrm{E}-10$ Previous Norm $=0.87886 \mathrm{E}-10$

EQUIL ITER 1 COMPLETED. NEW TRIANG MATRIX. MAX DOF INC $=0.5434 \mathrm{E}-15$

Element Formation Element $=210 \mathrm{Cum}$. Iter. $=18 \mathrm{CP}=493.410$

Time $=0.10000 \mathrm{E}-04$ Load Step $=1$ Substep $=2$ Equilibrium Iteration $=2$.

$F$ Convergence Norm $=0.70835 \mathrm{E}-10$ Previous Norm $=0.70835 \mathrm{E}-10$

$M$ Convergence Norm $=0.87886 \mathrm{E}-10$ Previous Norm $=0.87886 \mathrm{E}-10$

Element Formation Element $=370 \mathrm{Cum}$. Iter. $=18 \mathrm{CP}=498.060$

Time $=0.10000 \mathrm{E}-04$ Load Step $=1$ Substep $=2$ Equilibrium Iteration $=2$.

F Convergence Norm $=0.70835 \mathrm{E}-10$ Previous Norm $=0.70835 \mathrm{E}-10$

$\mathrm{M}$ Convergence Norm $=0.87886 \mathrm{E}-10$ Previous Norm $=0.87886 \mathrm{E}-10$

Element Formation Element $=430 \mathrm{Cum}$. Iter. $=18 \mathrm{CP}=499.590$ 
HNF-SD-TWR-CN-002

Rev. 0

Appendix A

Time $=0.10000 \mathrm{E}-04$ Load Step $=1$ Substep $=2$ Equilibrium Iteration $=2$. F Convergence Norm $=0.70835 \mathrm{E}-10$ Previous Norm $=0.70835 \mathrm{E}-10$

$M$ Convergence Norm $=0.87886 \mathrm{E}-10$ Previous Norm $=0.87886 \mathrm{E}-10$

Solution Preparation Element $=10 \mathrm{Cum}$. Iter. $=18 \mathrm{CP}=505.950$

Time $=0.10000 E-04$ Load Step $=1$ Substep $=2$ Equilibrium Iteration $=2$. F Convergence Norm $=0.70835 \mathrm{E}-10$ Previous Norm $=0.70835 \mathrm{E}-10$

. M Convergence Norm $=0.87886 \mathrm{E}-10$ Previous Norm $=0.87886 \mathrm{E}-10$

$$
\begin{aligned}
& \text { FORCE CONVERGENCE VALUE }=0.3586 \mathrm{E}-10 \text { CRITERION }=2.932 \quad<<\text { CONVERGED } \\
& \text { MOMENT CONVERGENCE VALUE }=0.5052 \mathrm{E}-11 \text { CRITERION }=24.48 \quad<<\text { CONVERGED }
\end{aligned}
$$

$>>>$ SOLUTION CONVERGED AFTER EQUILIBRIUM ITERATION 1

Element Output Element $=220$ Cum. Iter. $=17 \mathrm{CP}=511.050$

Time $=0.10000 \mathrm{E}-04$ Load Step $=1$ Substep $=2$ Equilibrium Iteration $=1$. F Convergence Norm $=0.35858 \mathrm{E}-10$ Previous Norm $=0.70835 \mathrm{E}-10$

$M$ Convergence Norm $=0.50519 \mathrm{E}-11$ Previous Norm $=0.87886 \mathrm{E}-10$

* * LOAD STEP 1 SUBSTEP 2 COMPLETED. CUM ITER = 17

$* *$ TIME $=0.100000 E-04 \quad$ TIME INC $=0.500000$ E-05

*. PROBLEM STATISTICS

ACTUAL NO. OF ACTIVE DEGREES OF FREEDOM $=4045$

R.M.S. WAVEFRONT SIZE $=125.8$

$\because *$ ANSYS BINARY FILE STATISTICS

BUFFER SIZE USED $=4096$

3.297 MB WRITIEN ON ELEMENT MATRIX FILE: file.emat

9.859 MB WRITTEN ON ELEMENT SAVED DATA FILE: file.esav

4.047 MB WRITTEN ON TRIANGULARIZED MATRIX FILE: file.tri

1.672 MB WRITTEN ON RESULTS FILE: file.rst
ANSYS REVISION 5.2
11:38:22 08/25/1997

PRINTOUT RESUMED BY /GOP

Load step file number 2. Begin solution ...

$* * * *$ ANSYS SOLVE COMMAND ****
*** WARNING ***$\quad$ CP $=519.700$ TIME $=11: 55: 53$

Coupled node set 6 has unused node 30577 .

*** WARNING *** CP $=519.700$ TIME $=11: 55: 53$

Coupled node set 12 has unused node 30577 .

*** WARNING *** CP= 519.700 TIME $=11: 55: 53$

Coupled node set 18 has unused node 30577 .

* WARNING *. $\quad C P=519.820 \quad$ TIME $=11: 55: 53$

Specified DOF constraint UY at unused node 30559.

** * WARNING ** $\quad \mathrm{CP}=519.820$ TIME $=11: 55: 53$

Specified DOF constraint ROTX at unused node 30559 . 
* * WARNING ** $\quad \mathrm{CP}=519.820$ TIME $=11: 55: 53$

Specified DOF constraint ROTZ at unused node 30559 .

** NOTE *. CP $=519.830 \quad$ TIME $=11: 55: 53$

The step data was checked and warning messages were found. Please review output or errors file ( file.err) for these warning messages.

** NOTE *.* CP $=519.830 \quad$ TIME $=11: 55: 53$

Results printout suppressed for interactive execute.

* * NOTE ** * CP= 519.830 TIME $=11: 55: 53$

Nonlinear analysis, NROPT set to 2 (modified Newton-Raphson solution procedure) for ALL DOFs.

\section{LOAD STEP OPTIONS}

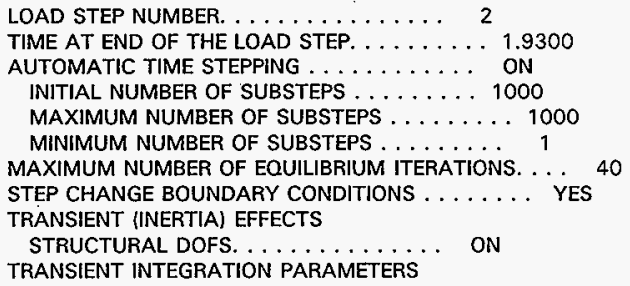


HNF-SD-TWR-CN-002

Rev. 0

Appendix A

Time $=0.19400 \mathrm{E}-02$ Load Step $=2$ Substep $=1$ Equilibrium Iteration $=1$. $F$ Convergence Norm $=0.35858 \mathrm{E}-10$ Previous Norm $=0.70835 \mathrm{E}-10$ $M$ Convergence Norm $=0.50519 E-11$ Previous Norm $=0.87886 \mathrm{E}-10$ FORCE CONVERGENCE VALUE $=6500 . \quad$ CRITERION $=7.131$ MOMENT CONVERGENCE VALUE $=0.5052 E-11$ CRITERION $=24.48$

Equation Solution Element $=290 \mathrm{Cum}$. Iter. $=18 \mathrm{CP}=542.710$

Time $=0.19400 \mathrm{E}-02$ Load Step $=2$ Substep $=1$ Equilibrium Iteration $=1$. F Convergence Norm $=6500.0 \quad$ Previous Norm $=6500.0$ $M$ Convergence Norm $=0.50519 \mathrm{E}-11$ Previous Norm $=0.50519 \mathrm{E}-11$ EQUIL ITER 1 COMPLETED. NEW TRIANG MATRIX. MAX DOF INC $=-0.3634 \mathrm{E}-03$

Element Formation Element $=170 \mathrm{Cum}$. Iter. $=19 \mathrm{CP}=550.510$

Time $=0.19400 E-02$ Load Step $=2$ Substep $=1$ Equilibrium Iteration $=2$. $\mathrm{F}$ Convergence Norm $=6500.0$ Previous Norm $=6500.0$

$\mathrm{M}$ Convergence Norm $=0.50519 \mathrm{E}-11$ Previous Norm $=0.50519 \mathrm{E}-11$

Element Formation Element $=470 \mathrm{Cum}$. Iter. $=19 \mathrm{CP}=558.670$

Time $=0.19400 E-02$ Load Step $=2$ Substep $=1$ Equilibrium Iteration $=2$. $F$ Convergence Norm $=6500.0$ Previous Norm $=6500.0$ $\mathrm{M}$ Convergence Norm $=0.50519 \mathrm{E}-11$ Previous Norm $=0.50519 \mathrm{E}-11$

Element Formation Element $=630 \mathrm{Cum}$. Iter. $=19 \mathrm{CP}=562.840$

Time $=0.19400 E-02$ Load Step $=2$ Substep $=1$ Equilibrium Iteration $=2$. $F$ Convergence Norm $=6500.0$ Previous Norm $=6500.0$ $\mathrm{M}$ Convergence Norm $=0.50519 \mathrm{E}-11$ Previous Norm $=0.50519 \mathrm{E}-11$ FORCE CONVERGENCE VALUE $=0.1621 \mathrm{E}-10$ CRITERION $=2.932$ MOMENT CONVERGENCE VALUE $=0.3234 \mathrm{E}-11$ CRITERION $=24.48$ $>>>$ SOLUTION CONVERGED AFTER EQUILIBRIUM ITERATION 1

Element Output Element $=10 \mathrm{Cum}$. Iter. $=18 \mathrm{CP}=565.900$

Time $=0.19400 E-02$ Load Step $=2$ Substep $=1$ Equilibrium iteration $=1$. $F$ Convergence Norm $=0.16215 \mathrm{E}-10$ Previous Norm $=6500.0$ $M$ Convergence Norm $=0.32338 \mathrm{E}-17$ Previous Norm $=0.50579 \mathrm{E}-11$

Element Output Element $=170 \mathrm{Cum}$. Iter. $=18 \mathrm{CP}=568.610$

Time $=0.19400 \mathrm{E}-02$ Load Step $=2$ Substep $=1$ Equilibrium Iteration $=1$. $F$ Convergence Norm $=0.16215 \mathrm{E}-10$ Previous Norm $=6500.0$ $\mathrm{M}$ Convergence Norm $=0.32338 \mathrm{E}-11$ Previous Norm $=0.50519 \mathrm{E}-11$

Element Output Element $=530 \mathrm{Cum}$. Iter. $=18 \mathrm{CP}=574.110$

Time $=0.19400 \mathrm{E}-02$ Load Step $=2$ Substep $=1$ Equilibrium Iteration $=1$. $F$ Convergence Norm $=0.16215 \mathrm{E}-10$ Previous Norm $=6500.0$

$M$ Convergence Norm $=0.32338 \mathrm{E}-11$ Previous Norm $=0.50519 \mathrm{E}-11$

*** LOAD STEP 2 SUBSTEP 1 COMPLETED. CUM ITER $=18$

** TIME $=0.193999 \mathrm{E}-02 \quad$ TIME INC $=0.192999 \mathrm{E}-02$

*** RESPONSE FREQ $=0.1159 \mathrm{E}-11$ PERIOD $=0.8631 \mathrm{E}+12 \mathrm{PTS} / \mathrm{CYC}=0.45 \mathrm{E}+15$

*. ESTIMATED TIME FOR ELEMENT 681 TO CHANGE STATUS IS 2.720

$\because$ AUTO STEP TIME: NEXT TIME INC $=0.19300 E-02$ UNCHANGED

Element Formation Element $=80$ Cum. Iter. $=19 \mathrm{CP}=580.090$

Time $=0.38700 \mathrm{E}-02$ Load Step $=2$ Substep $=2$ Equilibrium Iteration $=1$. $F$ Convergence Norm $=0.16215 \mathrm{E}-10$ Previous Norm $=6500.0$

$M$ Convergence Norm $=0.32338 \mathrm{E}-11$ Previous Norm $=0.50519 \mathrm{E}-11$

Element Formation Element $=350$ Cum. Iter. $=19 \mathrm{CP}=587.780$

Time $=0.38700 E-02$ Load $S t e p=2$ Substep $=2$ Equilibrium Iteration $=1$.

$F$ Convergence Norm $=0.16215 E-10$ Previous Norm $=6500.0$

M Convergence Norm $=0.32338 \mathrm{E}-11$ Previous Norm $=0.50519 \mathrm{E}-11$

Solution Preparation Element $=10 \mathrm{Cum}$. Iter. $=19 \mathrm{CP}=595.840$ 
HNF-SD-TWR-CN-002

Rev. 0

Appendix A

Time $=0.38700 \mathrm{E}-02$ Load Step $=2$ Substep $=2$ Equilibrium Iteration $=1$. $F$ Convergence Norm $=0.16215 \mathrm{E}-10$ Previous Norm $=6500.0$

$M$ Convergence Norm $=0.32338 \mathrm{E}-11$ Previous Norm $=0.50519 \mathrm{E}-11$

FORCE CONVERGENCE VALUE $=0.2587 E+05$ CRITERION $=26.04$

MOMENT CONVERGENCE VALUE $=0.3234 E-11$ CRITERION $=24.48$

Equation Solution Element $=420 \mathrm{Cum}$. Iter. $=19 \mathrm{CP}=599.750$

Time $=0.38700 E-02$ Load Step $=2$ Substep $=2$ Equilibrium Iteration $=1$.

$F$ Convergence Norm $=25871$. Previous Norm $=25871$.

$M$ Convergence Norm $=0.32338 \mathrm{E}-11$ Previous Norm $=0.32338 \mathrm{E}-11$

EQUIL ITER 1 COMPLETED. NEW TRIANG MATRIX. MAX DOF INC $=-0.1446 E-02$

Element Formation Element $=10 \mathrm{Cum}$. Iter $.=20 \mathrm{CP}=602.210$

Time $=0.38700 \mathrm{E}-02$ Load Step $=2$ Substep $=2$ Equilibrium Iteration $=2$.

F Convergence Norm $=25871$. Previous Norm $=25871$.

$M$ Convergence Norm $=0.32338 \mathrm{E}-11$ Previous Norm $=0.32338 \mathrm{E}-11$

Element Formation Element $=250$ Cum. Iter. $=20 \mathrm{CP}=609.390$

Time $=0.38700 E-02$ Load Step $=2$ Substep $=2$ Equilibrium Iteration $=2$.

$F$ Convergence Norm $=25871$. Previous Norm $=25871$.

$M$ Convergence Norm $=0.32338 \mathrm{E}-11$ Previous Norm $=0.32338 \mathrm{E}-11$

Element Formation Element $=560 \mathrm{Cum}$. Iter. $=20 \mathrm{CP}=617.460$

Time $=0.38700 \mathrm{E}-02$ Load Step $=2$ Substep $=2$ Equilibrium Iteration $=2$.

$F$ Convergence Norm $=25871$. Previous Norm $=25871$.

$M$ Convergence Norm $=0.32338 \mathrm{E}-11$ Previous Norm $=0.32338 \mathrm{E}-11$

FORCE CONVERGENCE VALUE $=0.1496 E-10 \quad$ CRITERION $=2.932$

MOMENT CONVERGENCE VALUE $=0.3691 \mathrm{E}-11$ CRITERION $=24.48$

$<<<$ CONVERGED

$>>>$ SOLUTION CONVERGED AFTER EQUILIBRIUM ITERATION 1

ITERATION SUMMARY FOR INTERMEDIATE STEPS HAVE BEEN DELETED.

Element Output Element $=370 \mathrm{Cum}$. Iter. $=34 \mathrm{CP}=1466.580$

Time $=1.9300$ Load Step $=2$ Substep $=17$ Equilibrium Iteration $=1$.

F Convergence Norm $=0.43574 \mathrm{E}-08$ Previous Norm $=0.29673 \mathrm{E}+08$

$M$ Convergence Norm $=0.33255 \mathrm{E}-11$ Previous Norm $=0.37324 \mathrm{E}-11$

Element Output Element $=390 \mathrm{Cum}$. Iter. $=34 \mathrm{CP}=1466.960$

Time $=1.9300$ Load Step $=2$ Substep $=17$ Equilibrium Iteration $=1$.

F Convergence Norm $=0.43574 \mathrm{E}-08$ Previous Norm $=0.29673 \mathrm{E}+08$

$M$ Convergence Norm $=0.33255 \mathrm{E}-11$ Previous Norm $=0.37324 \mathrm{E}-11$

Element Output Element $=450 \mathrm{Cum}$. Iter. $=34 \mathrm{CP}=1468.080$

Time $=1.9300$ Load Step $=2$ Substep $=17$ Equilibrium Iteration $=1$.

$F$ Convergence Norm $=0.43574 \mathrm{E}-08$ Previous Norm $=0.29673 \mathrm{E}+08$

$M$ Convergence Norm $=0.33255 \mathrm{E}-11$ Previous Norm $=0.37324 \mathrm{E}-11$

Element Output Element $=680 \mathrm{Cum}$. Iter. $=34 \mathrm{CP}=1471.810$

Time $=1.9300$ Load Step $=2$ Substep $=17$ Equilibrium Iteration $=1$.

$F$ Convergence Norm $=0.43574 \mathrm{E}-08$ Previous Norm $=0.29673 \mathrm{E}+08$

M Convergence Norm $=0.33255 \mathrm{E}-11$ Previous Norm $=0.37324 \mathrm{E}-11$

*** LOAD STEP 2 SUBSTEP 17 COMPLETED. CUM ITER $=34$

*** TIME $=1.93000 \quad$ TIME INC $=0.167276 \mathrm{E}-02$

** * RESPONSE FREO $=0.3486 \mathrm{E}-15$ PERIOD $=0.2868 \mathrm{E}+16 \quad \mathrm{PTS} / \mathrm{CYC}=0.17 \mathrm{E}+19$

ANSYS REVISION $5.2 \quad 11: 38: 22 \quad 08 / 25 / 1997$ 
PRINTOUT RESUMED BY /GOP

Load step file number 3 . Begin solution ...

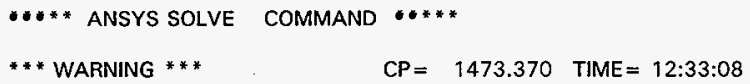

Coupled node set 6 has unused node 30577 .

*** WARNING *** CP $=1473.370$ TIME $=12: 33: 09$

Coupled node set 12 has unused node 30577 .

*** WARNING *** CP $=1473.370$ TIME $=12: 33: 09$

Coupled node set 18 has unused node 30577 .

* * * WARNING *** CP= 1473.490 TIME $=12: 33: 09$

Specified DOF constraint UY at unused node 30559.

*** WARNING *** CP= 1473.490 TIME $=12: 33: 09$

Specified DOF constraint ROTX at unused node 30559 .

*** WARNING *** CP= 1473.490 TIME $=12: 33: 09$

Specified DOF constraint ROTZ at unused node 30559.

*** NOTE *** CP $=1473.500$ TIME $=12: 33: 09$

The step data was checked and warning messages were found.

Please review output or errors file (file.err) for these warning

messages.

**NOTE ** CP= 1473.500 $\mathrm{TIME}=12: 33: 09$

Results printout suppressed for interactive execute.

*** NOTE ** $\quad \mathrm{CP}=1473.500$ TIME $=12: 33: 09$

Nonlinear analysis, NROPT set to 2 (modified Newton-Raphson solution

procedure) for ALL DOFs.

LOAD STEP OPTIONS

LOAD STEP NUMBER. . . . . . . . . 3

TIME AT END OF THE LOAD STEP. . . . . . . . 1.9900

NUMBER OF SUBSTEPS. . . . . . . . . . 600

MAXIMUM NUMBER OF EQUILIBRIUM ITERATIONS. . . 40

STEP CHANGE BOUNDARY CONDITIONS ....... YES

TRANSIENT (INERTIA) EFFECTS

STRUCTURAL DOFS. .......... ON

TRANSIENT INTEGRATION PARAMETERS

ALPHA . . . . . . . . . 0.25251

DELTA. . . . . . . . . . 0.50500

TERMINATE ANALYSIS IF NOT CONVERGED . . . . . YES (EXIT)

CONVERGENCE CONTROLS. . . . . . . . . USE DEFAULTS

INERTIA LOADS $X \quad Y \quad Z$

ACEL ....... $0.00000 E+000.00000 E+00386.40$ 
HNF-SD-TWR-CN-002

Rev. 0

Appendix A

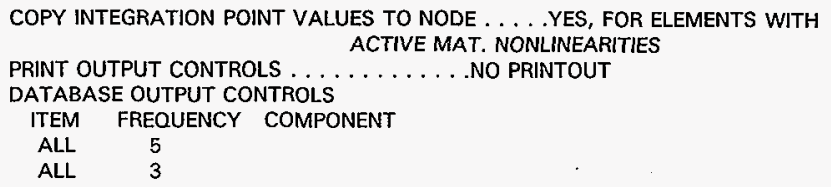

Element Formation Element $=10$ Cum. Iter. $=35 \mathrm{CP}=1475.530$

Time $=1.9301$ Load Step $=3$ Substep $=1$ Equilibrium Iteration $=1$.

F Convergence Norm $=0.43574 \mathrm{E}-08$ Previous Norm $=0.29673 \mathrm{E}+08$

$M$ Convergence Norm $=0.33255 E-11$ Previous Norm $=0.37324 E-11$

Element Formation Element $=290 \mathrm{Cum}$. Iter. $=35 \mathrm{CP}=1483.520$

Time $=1.9301$ Load Step $=3$ Substep $=1$ Equilibrium Iteration $=1$.

F Convergence Norm $=0.43574 \mathrm{E}-08$ Previous Norm $=0.29673 \mathrm{E}+08$

$M$ Convergence Norm $=0.33255 \mathrm{E}-11$ Previous Norm $=0.37324 \mathrm{E}-11$

Element Formation Element $=320 \mathrm{Cum}$. Iter. $=35 \mathrm{CP}=1484.500$

Time $=1.9301$ Load Step $=3$ Substep $=1$ Equilibrium Iteration $=1$.

F Convergence Norm $=0.43574 E-08$ Previous Norm $=0.29673 E+08$

$M$ Convergence Norm $=0.33255 E-11$ Previous Norm $=0.37324 \mathrm{E}-11$

Element Formation Element $=600 \mathrm{Cum}$. Iter. $=35 \mathrm{CP}=1491.250$

Time $=1.9301$ Load Step $=3$ Substep $=1$ Equilibrium Iteration $=1$.

F Convergence Norm $=0.43574 \mathrm{E}-08$ Previous Norm $=0.29673 \mathrm{E}+08$

$M$ Convergence Norm $=0.33255 \mathrm{E}-11$ Previous Norm $=0.37324 \mathrm{E}-11$

FORCE CONVERGENCE VALUE $=0.4966 \mathrm{E}+09$ CRITERION $=0.4966 \mathrm{E}+06$

MOMENT CONVERGENCE VALUE $=0.3325 E-11$ CRITERION $=24.48$

Equation Solution Element $=10 \mathrm{Cum}$. Iter. $=35 \mathrm{CP}=1494.940$

Time $=1.9301$ Load Step $=3$ Substep $=1$ Equilibrium Iteration $=1$.

$F$ Convergence Norm $=0.49658 \mathrm{E}+09$ Previous Norm $=0.49658 \mathrm{E}+09$

$M$ Convergence Norm $=0.33255 \mathrm{E}-11$ Previous Norm $=0.33255 \mathrm{E}-11$

EQUIL ITER 1 COMPLETED. NEW TRIANG MATRIX. MAX DOF INC $=-0.7454 \mathrm{E}-01$

Element Formation Element $=90 \mathrm{Cum}$. Iter. $=36 \mathrm{CP}=1501.800$

Time $=1.9301$ Load Step $=3$ Substep $=1$ Equilibrium Iteration $=2$.

$F$ Convergence Norm $=0.49658 \mathrm{E}+09$ Previous Norm $=0.49658 \mathrm{E}+09$

$M$ Convergence Norm $=0.33255 \mathrm{E}-11$ Previous Norm $=0.33255 \mathrm{E}-11$

Element Formation Element $=370 \mathrm{Cum}$. Iter. $=36 \mathrm{CP}=1509.900$

Time $=1.9301$ Load Step $=3$ Substep $=1$ Equilibrium Iteration $=2$.

$F$ Convergence Norm $=0.49658 \mathrm{E}+09$ Previous Norm $=0.49658 \mathrm{E}+09$

$M$ Convergence Norm $=0.33255 \mathrm{E}-11$ Previous Norm $=0.33255 \mathrm{E}-11$

Element Formation Element $=660 \mathrm{Cum}$. Iter. $=36 \mathrm{CP}=1517.090$

Time $=1.9301$ Load Step $=3$ Substep $=1$ Equilibrium Iteration $=2$.

F Convergence Norm $=0.49658 \mathrm{E}+09$ Previous Norm $=0.49658 \mathrm{E}+09$

$M$ Convergence Norm $=0.33255 \mathrm{E}-11$. Previous Norm $=0.33255 \mathrm{E}-11$

FORCE CONVERGENCE VALUE $=0.5479 \mathrm{E}-07$ CRITERION $=2.932 \ll<$ CONVERGED

MOMENT CONVERGENCE VALUE $=0.3868 E-11$ CRITERION $=24.48<<<$ CONVERGED

$>>>$ SOLUTION CONVERGED AFTER EQUILIBRIUM ITERATION 1

INTERMEDIATE LOAD STEPS' ITERATION SUMMARY HAVE BEEN DELETED. 
HNF-SD-TWR-CN-002

Rev. 0

Appendix A

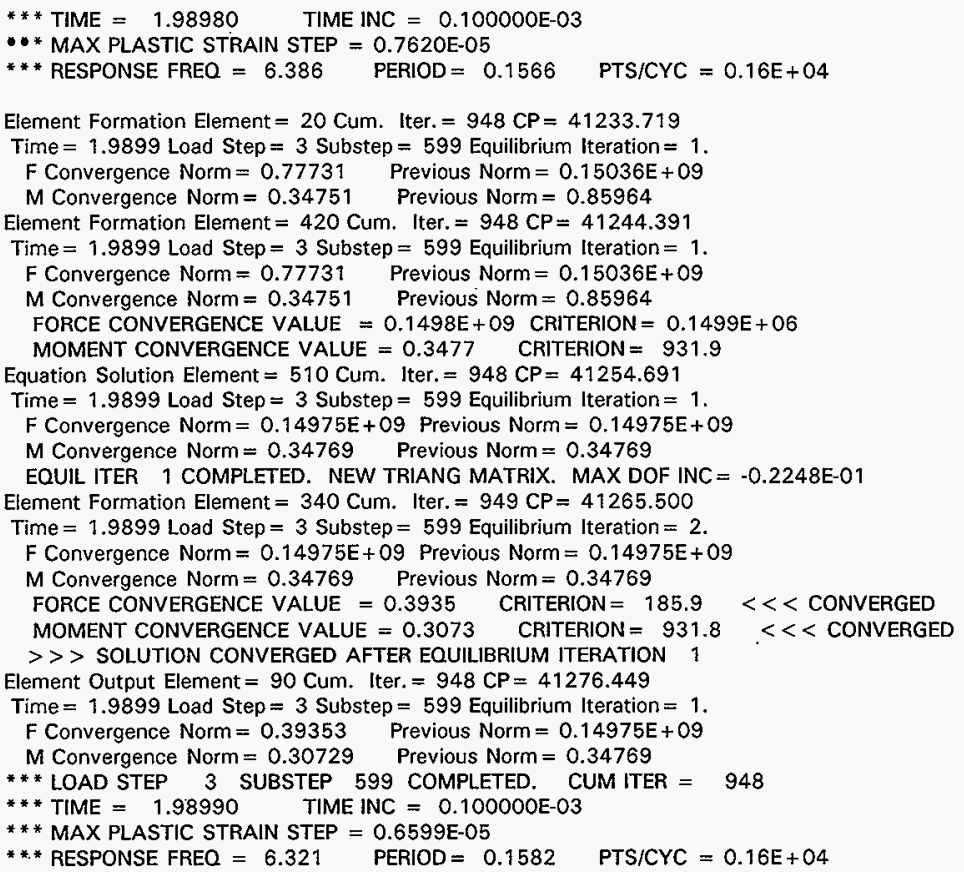

Element Formation Element $=30 \mathrm{Cum}$. Iter. $=949 \mathrm{CP}=41286.910$

Time $=1.9900$ Load Step $=3$ Substep $=600$ Equilibrium Iteration $=1$.

F Convergence Norm $=0.39353$ Previous Norm $=0.14975 \mathrm{E}+09$

$M$ Convergence Norm $=0.30729$ Previous Norm $=0.34769$

Element Formation Element $=430 \mathrm{Cum}$. Iter. $=949 \mathrm{CP}=41297.500$

Time $=1.9900$ Load Step $=3$ Substep $=600$ Equilibrium Iteration $=3$.

F Convergence Norm $=0.39353$ Previous Norm $=0.14975 \mathrm{E}+09$

$M$ Convergence Norm $=0.30729$ Previous Norm $=0.34769$

FORCE CONVERGENCE VALUE $=0.1491 \mathrm{E}+09$ CRITERION $=0.1493 \mathrm{E}+06$

MOMENT CONVERGENCE VALUE $=0.3074$ CRITERION $=931.8$

Equation Solution Element $=650 \mathrm{Cum}$. Iter. $=949 \mathrm{CP}=41308.320$

Time $=1.9900$ Load Step $=3$ Substep $=600$ Equilibrium Iteration $=1$.

F Convergence Norm $=0.14915 \mathrm{E}+09$ Previous Norm $=0.14915 \mathrm{E}+09$ 
HNF-SD-TWR-CN-002

Rev. 0

Appendix A

$M$ Convergence Norm $=0.30735$ Previous Norm $=0.30735$

EQUIL ITER 1 COMPLETED. NEW TRIANG MATRIX. MAX DOF INC $=-0.2239 E-01$

Element Formation Element $=370$ Cum. Iter. $=950 \mathrm{CP}=41319.191$

Time $=1.9900$ Load Step $=3$ Substep $=600$ Equilibrium Iteration $=2$.

$F$ Convergence Norm $=0.14915 E+09$ Previous Norm $=0.14915 E+09$

$M$ Convergence Norm $=0.30735$ Previous Norm $=0.30735$

FORCE CONVERGENCE VALUE $=5.453$ CRITERION $=185.9<<<$ CONVERGED

MOMENT CONVERGENCE VALUE $=0.6020 \quad$ CRITERION $=931.7 \quad<<<$ CONVERGED

$>>>$ SOLUTION CONVERGED AFTER EQUILIBRIUM ITERATION 1

Element Output Element $=110 \mathrm{Cum}$. Iter. $=949 \mathrm{CP}=41329.891$

Time $=1.9900$ Load Step $=3$ Substep $=600$ Equilibrium Iteration $=1$.

$\mathrm{F}$ Convergence Norm $=5.4527$ Previous Norm $=0.14915 \mathrm{E}+09$

$M$ Convergence Norm $=0.60200 \quad$ Previous Norm $=0.30735$

** * LOAD STEP 3 SUBSTEP 600 COMPLETED. CUM ITER $=949$

$* * *$ TIME $=1.99000 \quad$ TIME INC $=0.100000 E-03$

** * MAX PLASTIC STRAIN STEP $=0.5536 \mathrm{E}-05$

$* *$ * RESPONSE FREQ $=6.254 \quad$ PERIOD $=0.1599 \quad$ PTS $/ C Y C=0.16 E+04$

SOLU_LS4:

FINISH SOLUTION PROCESSING

$* * * *$ ROUTINE COMPLETED **** CP $=41338.820$

*** NOTE *** CP=41338.820 TIME $=03: 39: 35$

A total of 42 warnings and errors written to file.err.

BEGIN:

PURGE ALL SOLUTION AND POST DATA

SAVE ALL MODEL DATA

*** NOTE *** CP $=41338.941 \quad$ TIME $=03: 39: 36$,

NEW BACKUP FILE NAME $=$ file.dbb.

ALL CURRENT ANSYS DATA WRITTEN TO FILE NAME $=$ file.db FOR POSSIBLE RESUME FROM THIS POINT

NUMBER OF WARNING MESSAGES ENCOUNTERED = NUMBER OF ERROR MESSAGES ENCOUNTERED =

42

DATA INPUT WRITTEN ON file.log

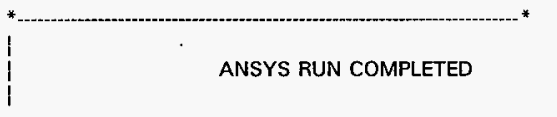


HNF-SD-TWR-CN-002

Rev. 0

Appendix A

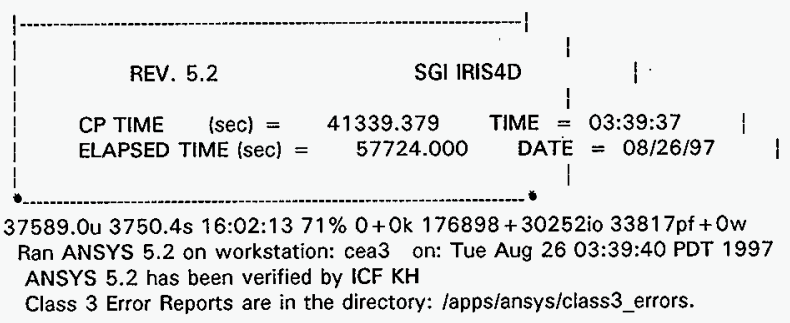


HNF-SD-TWR-CN-002

Rev. 0

Appendix A

POST26 SUMMARY OF VARIABLE EXTREME VALUES

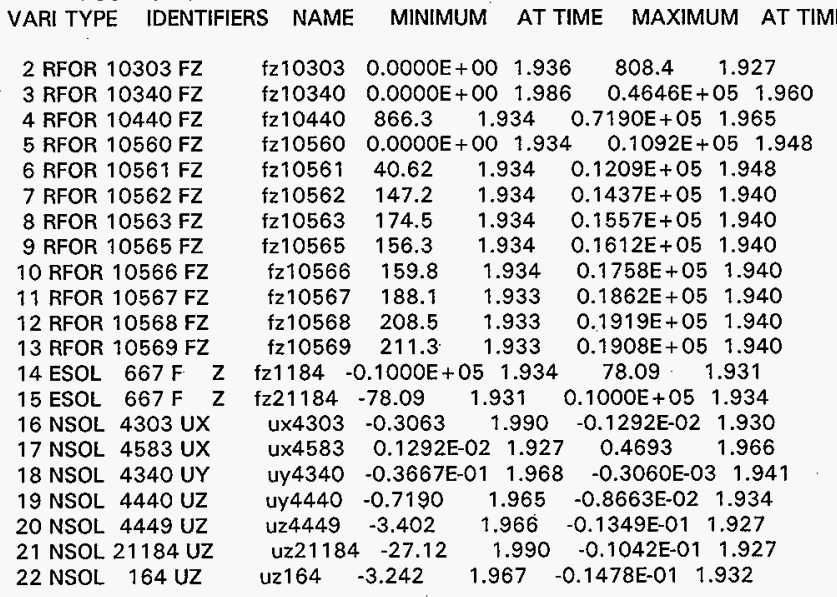


STORAGE COMPLETE FOR 202 DATA POINTS

SUMMARY OF VARIABLES STORED THIS STEP AND EXTREME VALUES

VARI TYPE IDENTIFIERS NAME MINIMUM AT TIME MAXIMUM AT TIME

\begin{tabular}{|c|c|c|c|c|c|c|c|}
\hline $\mathrm{OL}$ & 5 & & 7 & 38 & 27 & $\begin{array}{l}5268 . \\
6697\end{array}$ & 1.982 \\
\hline & & & & & & 6697. & 55 \\
\hline & 1 & & & & & 7764 & 1.937 \\
\hline & & & & & & \multicolumn{2}{|c|}{$0.1133 E+05 \quad 1.943$} \\
\hline & & & & & & 1005. & 1.940 \\
\hline & & & & & & -50.54 & \\
\hline & & & & & & 3014. & \\
\hline & & & IA & & 1.930 & \multicolumn{2}{|c|}{$0.1062 E+05 \quad 1.937$} \\
\hline & & & $f_{x}$ & \multicolumn{2}{|c|}{$-0.1026 \mathrm{E}+05 \quad 1.96$} & \multirow{2}{*}{$\begin{array}{r}1168 . \\
-4506\end{array}$} & 1.8 \\
\hline & 15 & & & -0 & 051.9 & & 1.92 \\
\hline & & & & & 1.932 & 517.8 & 1.9 \\
\hline & & & & & & \multicolumn{2}{|c|}{$0.1036 E+05$} \\
\hline & & & & & 1.990 & 9699. & 1.945 \\
\hline & & & & & 1.937 & 2321. & 1.980 \\
\hline & & & & & 1.937 & -42.90 & 1.932 \\
\hline & & & & & & \multicolumn{2}{|c|}{$0.1958 E+05 \quad 1.961$} \\
\hline & & & & & 1. & \multicolumn{2}{|c|}{$4104 . \quad 1.960$} \\
\hline & & & $f \times 514$ & $-0.1938 E$ & 05 & -165.3 & ? \\
\hline
\end{tabular}

POST26 SUMMARY OF VARIABLE EXTREME VALUES

VARI TYPE IDENTIFIERS NAME MINIMUM AT TIME MAXIMUM ATTIME

\begin{tabular}{|c|c|c|c|c|c|c|c|}
\hline $\mathrm{OL}$ & & & 57 & & 27 & \multicolumn{2}{|l|}{5268.} \\
\hline & & & & & & \multicolumn{2}{|l|}{6697.} \\
\hline & & & & & & \multicolumn{2}{|r|}{1.937} \\
\hline & & & & & & \multicolumn{2}{|c|}{$0.1133 E+05 \quad 1.943$} \\
\hline & & & & & & 1005. & 1.940 \\
\hline & & & & & & -50.54 & 1930 \\
\hline & & $x$ & & & & 3014. & \\
\hline & & $x$ & & & & \multicolumn{2}{|c|}{$0.1062 E+05 \quad 1.937$} \\
\hline & & $x$ & & \multicolumn{2}{|c|}{$-0.1026 \mathrm{E}+05 \quad 1.96$} & \multirow{2}{*}{$\begin{array}{r}1168 \\
-4506\end{array}$} & 1. \\
\hline & & $x$ & & & $05 \quad 1.94$ & & 1.92 \\
\hline & & $x$ & & & 1.932 & 517.8 & 1.986 \\
\hline & & Y & & & & \multicolumn{2}{|c|}{$0.1036 E+05 \quad 1.95$} \\
\hline & & $Y$ & & & & 9699. & 1.945 \\
\hline & & Y & & & 1.937 & 2321. & 30 \\
\hline & & $\mathrm{Y}$ & & & 1.937 & -42.90 & 1.932 \\
\hline & & $Y$ & & & 1.930 & \multirow{2}{*}{$\begin{array}{c}0.1958 E \\
4104 .\end{array}$} & 051.96 \\
\hline & & $\mathrm{Y}$ & & & 1.933 & & 1.960 \\
\hline & & $x$ & $f \times 514$ & -0.1938 & 1.9 & -165.3 & 1.92 \\
\hline
\end{tabular}


HNF-SD-TWR-CN-002 Rev. 0 Appendix B

APPENDIX B

TRANSFER PUMP DROP ANALYSIS 
/prep7

title,flex receiver platform - impact analysis et, 1 , shell 43

$r, 1,1.5 * * * *$ cover plate with hole $r, 2,1$. *** cover plate without hole

$r, 3,1$. $* * *$ bottom plate

$r, 4,1.515 * * *$ beam upper flange

$r, 5,0.515 \cdots *$ beam lower flange

$r, 6,0.295 * * *$ beam web

ex, $1,29 e 6$

nuxy, $1,0.3$

dens, $1,0.000734$

tb, bkin, 1, 1

tbdata, 1,36000, 145000 .

tbtemp,70

ex,2,290e6

csys, 0

$n, 300$

**** cover plate

$n, 302,, 16.75$

fill

$n, 304,, 24.75$

fill

$n, 306,40.375$

fill

$n, 308,55.375$

fill

$\mathrm{n}, 310, .70 .375$

fill

n, 312,,86.

fill

n,314,,94.

fill

ngen, 3, 15,300,314, 1,4.

ngen, $9,15,330,344,1,8$.

ngen, $3,15,450,464,1,4$.

ngen, $5,15,480,494,1,8.0625$

ngen, 3, 15,540,554,1,4.

ngen, $4,15,570,584,1,11.7$

mat, 1

type, 1

real, 3

e,330,345,346,331

egen, $8,15,-1$

egen, $2,1,-8$

$e, 480,495,496,481$

egen, $4,15,-1$

egen, $2,1,-4$

e, $570,585,586,571$

egen, $3,15,-1$

egen, $2,1,-3$

e. $484,499,500,485$

egen, $4,15,-1$ 


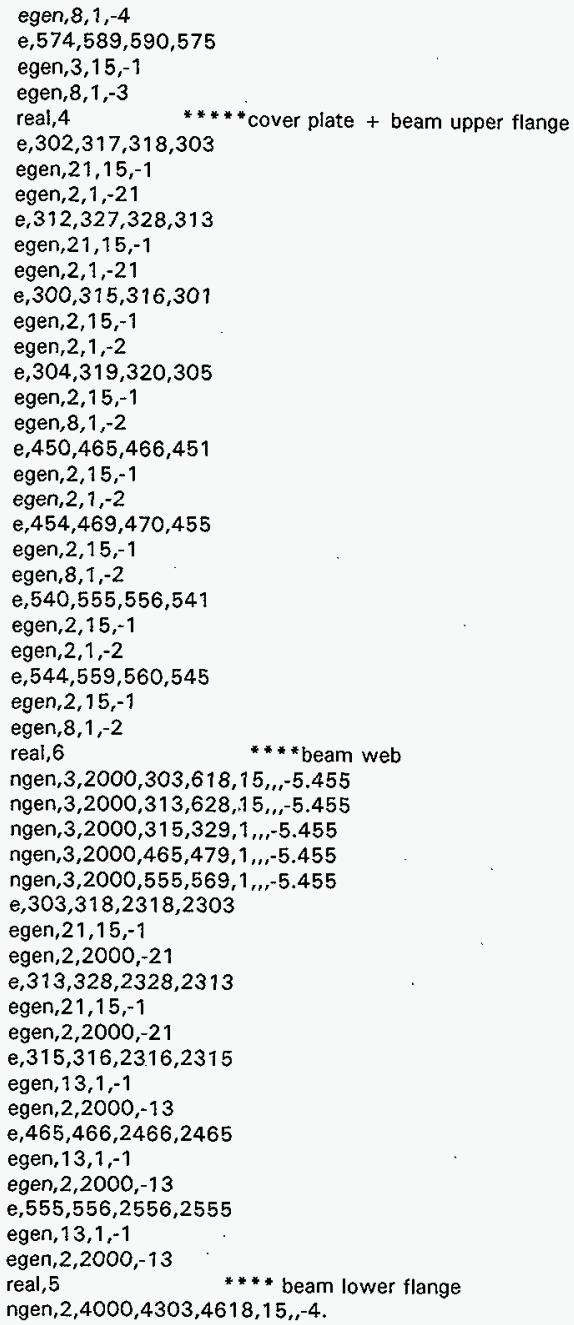


ngen, $2,5000,4303,4618,15,4$. ngen, $2,4000,4313,4628,15,-4$. ngen, $2,5000,4313,4628,15,4$. ngen, $2,4000,4315,4316,1,4$. ngen, $2,5000,4315,4316,1,4$. ngen, $2,4000,4320,4326,1,-4$. ngen, $2,5000,4320,4326,1,4$. ngen, $2,4000,4465,4466,1,-4$. ngen, $2,5000,4465,4466,1,4$. ngen, $2,4000,4470,4476,1,-4$. ngen, $2,5000,4470,4476,1,4$. ngen, $2,4000,4555,4556,1,-4$. ngen, $2,5000,4555,4556,1,4$. ngen, $2,4000,4560,4566,1,-4$. ngen, $2,5000,4560,4566,1,4$. e,4303,4318,8318,8303 egen, $21,15,-1$ $\mathrm{e}, 4313,4328,8328,8313$ egen, 21,15,-1 e,4303,4318,9318,9303 egen, $21,15,-1$ $e, 4313,4328,9328,9313$ egen, $21,15,-1$ $e, 4315,4316,8316,8315$ e,4315,4316,9316,9315 $e, 4316,8318,8303,8316$ e, $4316,8318,8333,9316$ e, $9318,4320,8320,9303$ e,9318,4320,9320,9333 $\mathrm{e}, 4320,4321,8321,8320$ egen, $6,1,-1$ e,4320,4321,9321,9320 egen, $6,1,-1$ $\mathrm{e}, 4326,8328,8313,8326$ e. $4326,8328,8343,9326$ $\mathrm{e}, 4465,4466,8466,8465$ e, $4465,4466,9466,9465$ $\mathrm{e}, 4466,8468,8453,8466$ e. $4466,8468,8483,9466$ $\mathrm{e}, 9468,4470,8470,9453$ e, $9468,4470,9470,9483$ e, $4470,4471,8471,8470$ egen, $6,1,-1$ e,4470,4471,9471,9470 egen, $6,1,-1$ $e, 4476,8478,8463,8476$ $\mathrm{e}, 4476,8478,8493,9476$ e,4555,4556,8556,8555 $e, 4555,4556,9556,9555$ $\mathrm{e}, 4556,8558,8543,8556$ $\mathrm{e}, 4556,8558,8573,9556$ $e, 9558,4560,8560,9543$ 
HNF-SD-TWR-CN-002

Rev. 0

Appendix B

e, $9558,4560,9560,9573$ $e, 4560,4561,8561,8560$ egen, $6,7,-1$

e,4560,4561,9561,9560

egen, $6,1,-1$

e, $4566,8568,8553,8566$ e. $4566,8568,8583,9566$

local, $13,1,40,55.375$

csys, 13

$\mathrm{n}, 100,25,0.01$

$\mathrm{n}, 108,25,90,0.01$

fill

$\mathrm{n}, 116,25,180,0.01$

fill

$\mathrm{n}, 117,25,-168.75,0.01$

$n, 124,25,-90,0.01$

fill

n, 131,25,-11.25,0.01

fill

ngen, $3,32,100,131,1,2 ., 0.01$

type, 1

real, 1

e, $100,132,133,101$

egen, $31,1,-1$

e, $131,163,132,100$

egen, $2,32,-32$

ngen, $2,30000,454,462,1, \ldots 0.01$

ngen, $2,30000,334,342,1, \ldots 0.01$

ngen, $2,30000,357,447,15, \ldots 0.01$

ngen, $2,30000,349,439,15,, 0.01$

e, 164,30458,30459,165

egen, $4,1,-1$

e, 168,30462,30447,169

e, 169,30447,30432,170

e, 170,30432,30417,171

e, $171,30417,30402,172$

e, 172,30402,30387,173

e, 173,30387,30372,174

e, $174,30372,30357,175$

e, $175,30357,30342,176$

e, 176,30342,30341,177

e, 177,30341,30340,178

e, 178,30340,30339,179

e, $179,30339,30338,180$

e, $180,30338,30337,181$

e,181,30337,30336,182

e.182,30336,30335,183

e, 183,30335,30334,184

e,184,30334,30349,185

e, $185,30349,30364,186$

e, $186,30364,30379,187$

e,187,30379,30394,188 
e, $188,30394,30409,189$ $\mathrm{e}, 189,30409,30424,190$ e, 190,30424,30439,191 e, 191,30439,30454,192 e, $192,30454,30455,193$ egen, $3,1,-1$

e, $195,30457,30458,164$ csys, 0

$\mathrm{cp}, 1, \mathrm{uz}, 372,30372$ $\mathrm{cp}, 2, \mathrm{uz}, 432,30432$ $\mathrm{cp}, 3, \mathrm{uz}, 456,30456$ $\mathrm{cp}, 4, \mathrm{uz}, 460,30460$ $\mathrm{cp}, 5, \mathrm{uz}, 364,30364$ $\mathrm{cp}, 6, \mathrm{uz}, 424,30424$ $\mathrm{cp}, 7, \mathrm{uz}, 336,30336$ $\mathrm{cp}, 8, \mathrm{uz}, 340,30340$ $\mathrm{cp}, 9, \mathrm{ux}, 372,30372$ $\mathrm{cp}, 10, \mathrm{ux}, 432,30432$ $c p, 11, u \times, 456,30456$ $c p, 12, u \times, 460,30460$ $\mathrm{cp}, 13, \mathrm{ux}, 364,30364$ $c p, 14, \mathrm{ux}, 424,30424$ $c p, 15, \mathrm{ux}, 336,30336$ $\mathrm{cp}, 76, \mathrm{ux}, 340,30340$ $\mathrm{cp}, 77, \mathrm{uy}, 372,30372$ $c p, 18, u y, 432,30432$ $\mathrm{cp}, 19, \mathrm{yy}, 456,30456$ $c p, 20, u y, 460,30460$ $\mathrm{cp}, 21, \mathrm{uy}, 364,30364$ cp, 22, uy, 424,30424 $c p, 23, u y, 336,30336$ $\mathrm{cp}, 24, \mathrm{uy}, 340,30340$ et, 5 , combin 14,1 $r, 12,10$.

type, 5

real, 12

ngen, $2,6000,4303,4313,10,-.01$

e, 4303,10303

$e, 4313,10313$

ngen, $2,6000,4618,4628,10,0.01$ e, 4618,10618

e, 4628,10628

et, 6, combin 14,2

$r, 13,10$.

type, 6

real, 13

ngen, $2,6000,4465,4555,90,-0.01$

$\mathrm{e}, 4465,10465$

e,4555, 10555

ngen, $2,6000,4479,4569,90, . .01$

$\mathrm{e}, 4479,10479$

$e, 4569,10569$ 
nsel, $,, 10303,10313,10$

nsel, $a_{2,, 10618,10628,10}$

nsel,a,,,10465, 10555,90

nsel, $a_{2, \ldots}$ 10479, 10569,90

d,alf,all

alls

csys, 0

ngen, $2,7000,4315,4329,1, \ldots-0.01$

ngen, $2,7000,4465,4479,14, \ldots-0.01$

ngen, $2,7000,4555,4569,14, \ldots-0.01$

ngen, $2,7000,4618,4628,10,,,-0.01$

et, 2 , contac $52, \ldots, \ldots, 1$

$\mathrm{r}, 11,1.0 \mathrm{e} 7,1$

$r, 20,1.0 e 6,1$

type, 2

real, 11 .

e, 11315,4315

egen, $15,1,-1$

e, 11465,4465

e, 11479,4479

e, 11555,4555

e.11569,4569

e, 11618,4618

e. 11628,4628

real, 20

$e, 334,30334$

egen, $2,1,-1$

e, 337,30337

egen, $3,1,-1$

$e, 341,30341$

egen, $2,1,-1$

e, 357,30357

e, 387,30387

egen, $3,15,-1$

$\mathrm{e}, 447,30447$

$e, 349,30349$

e, 379,30379

egen, $3,15,-1$

e,439,30439

$e, 454,30454$

egen, $2,1,-1$

$e, 457,30457$

egen, $3,1,-7$

$e, 461,30461$

egen, $2,1,-1$

nsel,s,node,,11315,11329

nsel, a,node, $11465,11479,14$

nsel,a,node,, $11555,11569,14$

nsel, a, node, $11618,11628,10$

d,all, all

alls

local, $15,0,40,55.375$ 
HNF-SD-TWR-CN-002

Rev. 0

Appendix B

csys $_{r} 15$

type, 1

mat, 2

$r, 8,12.0$

real, 8

$\mathrm{n}, 20001,-16,-16,20$.

$\cdots \cdots$ top plate

$n, 20009,16,-16,20$.

fill

ngen, $9,9,20001,20009,1,4$

e,20001,20002,20011,20010

egen, $8,1,-1$

egen, $8,9,-8$

csys, 13

$\mathrm{n}, 20100,25,20$.

$\mathrm{n}, 20108,25,90,20$.

fill

n,20116,25,180,20.

fill

$\mathrm{n}, 20117,25,-168.75,20$.

$\mathrm{n}, 20124,25,-90,20$.

fill

$\mathrm{n}, 20131,25,-11,25,20$.

fill

e,20045,20100,20101,20054

e,20054,20101,20102,20063

$e, 20063,20102,20103,20072$

e,20072,20103,20104,20081

- e,20081,20104,20105,20080

e,20080,20105,20106,20079

$\mathrm{e}, 20079,20106,20107,20078$

$\mathrm{e}, 20078,20107,20108,20077$

e,20077,20108,20109,20076

e,20076,20109,20110,20075

e,20075,20110,20111,20074

$e, 20074,20111,20112,20073$

e,20073,20112,20113,20064

$\mathrm{e}, 20064,20113,20114,20055$

e, $20055,20114,20115,20046$

e,20046,20115,20116,20037

e,20037,20116,20117,20028

$e, 20028,20117,20118,20019$

e, $20019,20118,20119,20010$

e,20010,20119,20120,20001

e,20001,20120,20121,20002

e,20002,20121,20122,20003

$\mathrm{e}, 20003,20122,20123,20004$

$e, 20004,20123,20124,20005$

e,20005,20124,20125,20006

e,20006,20125,20126,20007

e,20007,20126,20127,20008

e, 20008,20127,20128,20009

e,20009,20128,20129,20018 
HNF-SD-TWR-CN-002

Rev. 0

Appendix B

e,20018,20129,20130,20027

e,20027,20130,20131,20036

e,20036,20131,20100,20045 ngen, $2,32,20100,20131,1,4$.

e,20100,20132,20133,20101 egen, $31,1,-1$

$\mathrm{e}, 20131,20163,20132,20100$

et, 3, combin $40, \ldots 3$

$r, 9,23500, \ldots, 2350$

type, 3

real, 9

e, 132,20132

egen, $32,1,-1$

nsel,s,node, ,20132,20156,8

$d$, all, ux, ,., uy, rotx, roty, rotz

alls

et, 4, combin $40,1,3,,, 2$

$\mathrm{g}=386.4$

$r, 25,100000,(2000 / g), 720$.

ngen, 2,3000,20041,...,720.

type, 4

real, 25

e,20041,23041

tunif, 70 .

alls

save

fini

isolu

antype,trans

kbc, 1

acel,.,g

d,23041,uz

timint, off

time, 0.00001

nsubst, 2

neqit, 40

Iswrite

timint, on

time, 1.93

nsubst, 1200

outres, 5

autots, on

ddele, 23041,uz

Iswrite

time, 1.98

nsubst, 500

outres, 3

neqit, 40

autots, off

Iswrite

Issolve, 1,3

fini 
HNF-SD-TWR-CN-002

Rev. 0

Appendix B

lexit

Running ANSYS 5.2 on workstation: cea7 on: Wed Sep 3 13:36:39 PDT 1997

ANSYS 5.2 has been verified by ICF KH

Class 3 Error Reports are in the directory: /apps/ansys/class3_errors.

Executing /apps/ansys/sgi/ansys52/bin/ansys.e52

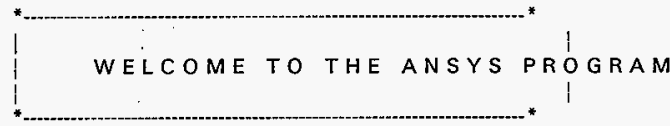

$* * * *$ DISCLAIMER OF WARRANTY $* * * * *$
$* * * * *$ AND NOTICE OF COPYRIGHT $* * * * *$

This ANSYS(R) software product (the Program), its Help System (Help System), and program documentation (Documentation) are furnished by ANSYS, Inc. under an ANSYS License Agreement that contains provisions concerning non-disclosure, copying, length and nature of use, warranties, disclaimers and remedies, and other provisions. The Program may be used or copied only in accordance with the terms of that License Agreement. Some of those terms are summarized here.

The Program should only be used by qualified persons. The determination as to who is qualified to use the Program is the obligation of the Licensee under the License Agreement.

NEITHER ANSYS, INC. NOR THE DISTRIBUTOR SUPPLYING THE PROGRAM (THE DISTRIBUTOR) GUARANTEES THE USEFULNESS OF THE RESULTS OF ANY ANALYSIS PERFORMED WITH THIS PROGRAM, ITS HELP SYSTEM, OR DOCUMENTATION. It is the responsibility of the Licensee or user to confirm the usefuiness and accuracy of all the solutions.

The Help System and Documentation consist of the ANSYS User's Manual and various other manuals. The User's Manual consists ONLY of the following four volumes: Procedures, Commands, Elements, and Theory. The User's Manual is identified with the words "ANSYS User's Manual" at the bottom of each page.

EXCEPT AS PROVIDED IN THE LICENSE AGREEMENT, NEITHER ANSYS, INC. NOR THE DISTRIBUTOR SHALL BE LIABLE FOR THE NEGLIGENT PREPARATION OF THE PROGRAM, THE HELP SYSTEM, OR USER'S MANUAL; OR FOR ANY TECHNICAL, EDITORIAL, OR OTHER ERRORS OR OMIȘSIONS WHICH THE HELP SYSTEM OR USER'S MANUAL MIGHT CONTAIN. ANSYS, INC. SHALL. NOT BE LIABLE FOR INCIDENTAL, CONSEOUENTIAL, COMPENSATORY OR EXEMPLARY DAMAGES RESULTING FROM ANY SUCH 
NEGLIGENT PREPARATION OR ERROR.

EXCEPT AS PROVIDED IN THE LICENSE AGREEMENT, ANSYS, INC. AND

THE DISTRIBUTOR HEREBY DISCLAIM ANY EXPRESS OR IMPLIED

WARRANTY, INCLUDING BUT NOT LIMITED TO, THE WARRANTY OF

MERCHANTABILITY OR FITNESS FOR A PARTICULAR PURPOSE WITH REGARD

TO THE PROGRAM OR THE CONTENTS, INFORMATION, AND INSTRUCTIONS

CONTAINED IN THE HELP SYSTEM OR USER'S MANUAL, WHETHER SAID

WARRANTIES ARISE UNDER PROVISIONS OF ANY LAW OF THE UNITED

STATES OF AMERICA OR ANY STATE THEREOF OR ANY OTHER COUNTRY, OR

PURSUANT TO THE PROVISIONS OF THE UNITED NATIONS CONVENTION ON

CONTRACTS FOR THE INTERNATIONAL SALE OF GOODS.

Examples, solutions, theories, results, methods, and references

to other documents are provided in the Help System and User's

Manual for guidance and explanation only. THEY ARE NOT

GUARANTEED TO PROVIDE THE USER WITH THE MOST ACCURATE, USEFUL, OR CORRECT ANALYSIS FOR ANY PARTICULAR PROBLEM.

The Program, Help System, and Documentation are protected by United States copyright law. You may print pages from the Help System to a printer for your own personal use. You may not further copy or reproduce such pages in any form without the prior written permission of ANSYS, Inc.

ANSYS, Inc. is endeavoring to make the ANSYS program as complete, accurate, and easy to use as possible. Suggestions and comments are welcome. Please bring any errors in either the Documentation or the Program results to the attention of ANSYS, Inc. by contacting your Distributor.

Copyright 1971, 1978, 1982, 1983, 1985, 1987, 1989, 1992, 1993, 1994,1995 by SAS IP as an unpublished work. Proprietary data--unauthorized use, distribution, or duplication, is prohibited. All rights reserved.

*** WARNING ***

AUTHORIZATION FILE WILL. SOON EXPIRE.

CONTACT YOUR LOCAL ANSYS DISTRIBUTOR FOR DETAILS.

AFTER YOU HAVE READ AND UNDERSTOOD THE PREVIOUS DISCLAIMER, PRESS <CR > OR <ENTER > TO CONTINUE

\section{**.* ANSYS COMMAND LINE ARGUMENTS \\ NONE \\ ** NOTE ** $\quad \mathrm{CP}=2.460$ TIME $=13: 36: 46$}

There are no parameters and no abbreviations defined.

32207 VERSION $=$ SGI IRIS4D REVISION $=5.2$

FOR SUPPORT CALL K MCMillian 373- PHONE JLR 206-353-8089 FAX FAX 509-373-6975

CURRENT JOBNAME $=$ file $13: 36: 46$ SEP $03,1997 \mathrm{CP}=2.470$ 
RUN SETUP PROCEDURE FROM FILE = /apps/ansys/sgi/ansys52/docu/start.ans

INPUT FILE $=$ /apps/ansys/sgi/ansys $52 /$ docu/start.ans LINE $=0$

BEGIN:

$* * * *$ ANSYS - ENGINEERING ANALYSIS SYSTEM REVISION $5.2 \quad * * * * *$
$32207 \quad$ VERSION =SGI IRIS4D 13:36:47 SEP 03, $1997 \mathrm{CP}=2.620$

FOR SUPPORT CALL K MCMillian 373- PHONE JLR 206-353-8089 FAX FAX 509-373-6975

**.* ANSYS ANALYSIS DEFINITION (PREP7)

ENTER /SHOW,DEVICE-NAME TO ENABLE GRAPHIC DISPLAY

ENTER FINISH TO LEAVE PREP7

PRINTOUT KEY SET TO /GOPR (USE /NOPR TO SUPPRESS)

PREP7:

TITLE $=$

flex receiver platform - impact analysis

PREP7:

ELEMENT TYPE 1 IS SHELL43 4-NODE STRUCTURAL SHELL

$\operatorname{KEYOPT}(1-12)=0 \begin{array}{llllllllllll}0 & 0 & 0 & 0 & 0 & 0 & 0 & 0 & 0 & 0 & 0 & 0\end{array}$

CURRENT NODAL DOF SET IS UX UY UZ ROTX ROTY ROTZ THREE-DIMENSIONAL MODEL

PREP7:

REAL CONSTANT SET 1 ITEMS 1 TO 6

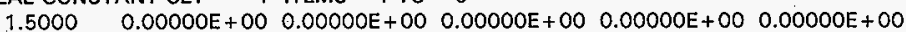

PREP7:

REAL CONSTANT SET 2 ITEMS 1 TO 6 $\begin{array}{llllllll}1.0000 & 0.00000 E+00 & 0.00000 E+00 & 0.00000 E+00 & 0.00000 E+00 & 0.00000 E+00\end{array}$

PREP7:

REAL CONSTANT SET 3 ITEMS 1 TO 6

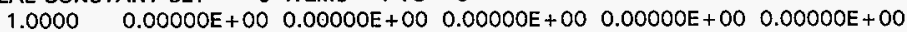

PREP7: 
HNF-SD-TWR-CN-002

Rev. 0

Appendix B

REAL CONSTANT SET 4 ITEMS 1 TO 6

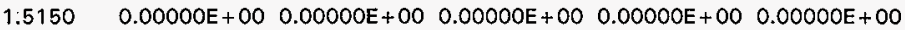

PREP7:

REAL CONSTANT SET 5 ITEMS 1 TO 6

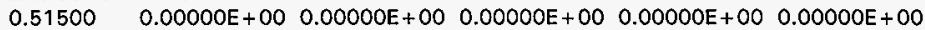

PREP7:

REAL CONSTANT SET 6 ITEMS 1 TO 6

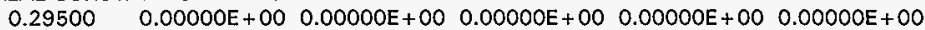

PREP7:

MATERIAL 1 EX $=0.2900000 E+08$

PREP7:

MATERIAL 1 NUXY $=0.3000000$

PREP7:

MATERIAL $\uparrow \quad$ DENS $=0.7340000 E-03$

PREP7:

DEFINE DATA TABLE BKIN FOR MATERIAL 1

WITH A MAXIMUM OF 1 TEMPERATURE SPECIFICATIONS

PREP7:

DATA FOR BKIN TABLE FOR MATERIAL 1 AT TEMPERATURE $=0.00000 E+00$

LOC $=136000 . \quad 0.14500 E+06$

PREP7:

TEMPERATURE TO BE USED FOR THE NEXT TBDAT COMMAND $=70.000$

TEMPERATURE SPECIFICATION $=1$

PREP7:

MATERIAL 2 EX $=0.2900000 E+09$

PREP7:

ACTIVE COORDINATE SYSTEM SET TO O (CARTESIAN)

PREP7:

NODE $300 \mathrm{KCS}=0 \quad X, Y, Z=0.00000 E+000.00000 E+000.00000 E+00$ 
PREP7:

NODE $302 \mathrm{KCS}=\begin{array}{llll}0 & X, Y, Z=0.00000 E+00 & 16.750 & 0.00000 E+00\end{array}$

PREP7:

FILL 1 POINTS BETWEEN NODE 300 AND NODE 302 START WITH NODE 301 AND INCREMENT BY 1

PREP7:

NODE $304 \mathrm{KCS}=0 \mathrm{X}, Y, Z=0.00000 E+0024.750$

$0.00000 E+00$

PREP7:

FILL 1 POINTS BETWEEN NODE 302 AND NODE 304 START WITH NODE 303 AND INCREMENT BY 1

PREP7:

NODE $306 \mathrm{KCS}=0 \quad X, Y, Z=0.00000 E+00 \quad 40.375 \quad 0.00000 E+00$

PREP7:

FILL 1 POINTS BETWEEN NODE 304 AND NODE .306 START WITH NODE 305 AND INCREMENT BY .1

PREP7:

NODE $308 \mathrm{KCS}=0 \quad X, Y, Z=0.00000 E+00 \quad 55.375 \quad 0.00000 E+00$

PREP7:

FILL 1 POINTS BETWEEN NODE 306 AND NODE 308 START WITH NODE 307 AND INCREMENT BY 1

PREP7:

NODE $310 \mathrm{KCS}=0 \quad X, Y, Z=0.00000 E+00 \quad 70.375 \quad 0.00000 E+00$

PREP7:

FILL 1 POINTS BETWEEN NODE 308 AND NODE 310 START WITH NODE 309 AND INCREMENT BY 1

PREP7:

NODE $312 \mathrm{KCS}=0 \quad X, Y, Z=0.00000 E+00 \quad 86.000 \quad 0.00000 E+00$

PREP7:

FILL 1 POINTS BETWEEN NODE 310 AND NODE 312 


$$
\begin{array}{r}
\text { HNF-SD-TWR-CN-002 } \\
\text { Rev. } 0 \\
\text { Appendix B }
\end{array}
$$

START WITH NODE 311 AND INCREMENT BY 1

PREP7:

NODE $314 \mathrm{KCS}=0 \quad X, Y, Z=0.00000 E+0094.000 \quad 0.00000 E+00$

PREP7:

FILL 1 POINTS BETWEEN NODE 312 AND NODE 314

START WITH NODE 313 AND INCREMENT BY 1

PREP7:

GENERATE 3 TOTAL SETS OF NODES WITH INCREMENT 15

SET IS SELECTED NODES IN RANGE 300 TO 314 IN STEPS OF. 1

GEOMETRY INCREMENTS ARE $4.0000 \quad 0.00000 \mathrm{E}+00 \quad 0.00000 \mathrm{E}+00 \mathrm{SPACING}=1.0000$

PREP7:

GENERATE 9 TOTAL SETS OF NODES WITH INCREMENT 15

SET IS SELECTED NODES IN RANGE 330 TO 344 IN STEPS OF 1

GEOMETRY INCREMENTS ARE $8.0000 \quad 0.00000 \mathrm{E}+000.00000 \mathrm{E}+00$ SPACING $=1.0000$

PREP7:

GENERATE 3 TOTAL SETS OF NODES WITH INCREMENT 15

SET IS SELECTED NODES IN RANGE 450 TO 464 IN STEPS OF 1

GEOMETRY INCREMENTS ARE $4.0000 \quad 0.00000 \mathrm{E}+00 \quad 0.00000 \mathrm{E}+00$ SPACING $=1.0000$

PREP7:

GENERATE 5 TOTAL SETS OF NODES WITH INCREMENT 15

SET IS SELECTED NODES IN RANGE 480 TO 494 IN STEPS OF 1

GEOMETRY INCREMENTS ARE $8.0625 \quad 0.00000 \mathrm{E}+00 \quad 0.00000 \mathrm{E}+00$ SPACING $=1.0000$

PREP7:

GENERATE 3 TOTAL SETS OF NODES WITH INCREMENT 15

SET IS SELECTED NODES IN RANGE 540 TO 554 IN STEPS OF 1

GEOMETRY INCREMENTS ARE $4.0000 \quad 0.00000 \mathrm{E}+00 \quad 0.00000 \mathrm{E}+00$ SPACING $=1.0000$

PREP7:

GENERATE 4 TOTAL SETS OF NODES WITH INCREMENT 15

SET IS SELECTED NODES IN RANGE 570 TO 584 IN STEPS OF 1

GEOMETRY INCREMENTS ARE $11.700 \quad 0.00000 \mathrm{E}+00 \quad 0.00000 \mathrm{E}+00 \mathrm{SPACING}=1.0000$

PREP7:

MATERIAL NUMBER SET TO 1

PREP7: 
ELEMENT TYPE SET TO 1

PREP7:

REAL CONSTANT NUMBER $=3$

PREP7:

$\begin{array}{llllll}\text { ELEMENT } & 1 & 330 & 345 & 346 & 331\end{array}$

PREP7:

GENERATE 8 TOTAL SETS OF ELEMENTS WITH NODE INCREMENT OF 15 SET IS SELECTED ELEMENTS IN RANGE 1 TO 1 IN STEPS OF 1 MAXIMUM ELEMENT NUMBER $=8$

PREP7:

GENERATE 2 TOTAL SETS OF ELEMENTS WITH NODE INCREMENT OF 1 SET IS SELECTED ELEMENTS IN RANGE 1 TO 8 IN STEPS OF 1 MAXIMUM ELEMENT NUMBER $=16$

PREP7:

$\begin{array}{llllll}\text { ELEMENT } & 17 & 480 & 495 & 496 & 481\end{array}$

PREP7:

GENERATE 4 TOTAL SETS OF ELEMENTS WITH NODE INCREMENT OF 15 SET IS SELECTED ELEMENTS IN RANGE 17 TO 17 IN STEPS OF 1 MAXIMUM ELEMENT NUMBER $=20$

PREP7:

GENERATE 2 TOTAL SETS OF ELEMENTS WITH NODE INCREMENT OF 1 SET IS SELECTED ELEMENTS IN RANGE 17 TO 20 IN STEPS OF 1 MAXIMUM ELEMENT NUMBER $=24$

PREP7:

ELEMENT 25 570 585586 571

PREP7:

GENERATE 3 TOTAL SETS OF ELEMENTS WITH NODE INCREMENT OF 15 SET IS SELECTED ELEMENTS IN RANGE 25 TO 25 IN STEPS OF 1 MAXIMUM ELEMENT NUMBER = 27

PREP7:

GENERATE 2 TOTAL SETS OF ELEMENTS WITH NODE INCREMENT OF 1 SET IS SELECTED ELEMENTS IN RANGE 25 TO 27 IN STEPS OF 1 
HNF-SD-TWR-CN-002

Rev. 0 Appendix B

MAXIMUM ELEMENT NUMBER $=30$

PREP7:

$\begin{array}{llllll}\text { ELEMENT } & 31 & 484 & 499 & 500 & 485\end{array}$

PREP7:

GENERATE 4 TOTAL SETS OF ELEMENTS WITH NODE INCREMENT OF 15 SET IS SELECTED ELEMENTS IN RANGE 31 TO 31 IN STEPS OF 1 MAXIMUM ELEMENT NUMBER $=34$

PREP7:

GENERATE 8 TOTAL SETS OF ELEMENTS WITH NODE INCREMENT OF 1 SET IS SELECTED ELEMENTS IN RANGE 31 TO 34 IN STEPS OF 1 MAXIMUM ELEMENT NUMBER $=62$

PREP7:

$\begin{array}{llllll}\text { ELEMENT } & 63 & 574 & 589 & 590 & 575\end{array}$

PREP7:

GENERATE 3 TOTAL SETS OF ELEMENTS WITH NODE INCREMENT OF 15 SET IS SELECTED ELEMENTS IN RANGE 63 TO 63 IN STEPS OF 1 MAXIMUM ELEMENT NUMBER $=65$

PREP7:

GENERATE 8 TOTAL SETS OF ELEMENTS WITH NODE INCREMENT OF 1 SET IS SELECTED ELEMENTS IN RANGE 63 TO 65 IN STEPS OF 1 MAXIMUM ELEMENT NUMBER $=86$

PREP7:

REAL CONSTANT NUMBER $=$ 4

PREP7:

$\begin{array}{llllll}\text { ELEMENT } & 87 & 302 & 317 & 318 & 303\end{array}$

PREP7:

GENERATE 21 TOTAL SETS OF ELEMENTS WITH NODE INCREMENT OF 15 SET IS SELECTED ELEMENTS IN RANGE 87 TO 87 IN STEPS OF 1 MAXIMUM ELEMENT NUMBER $=107$

PREP7:

GENERATE 2 TOTAL SETS OF ELEMENTS WITH NODE INCREMENT OF 1 SET IS SELECTED ELEMENTS IN RANGE 87 TO 107 IN STEPS OF 1 
HNF-SD-TWR-CN-002

Rev. 0

Appendix B

MAXIMUM ELEMENT NUMBER $=128$

PREP7:

$\begin{array}{llllll}\text { ELEMENT } & 129 & 312 & 327 & 328 & 313\end{array}$

PREP7:

GENERATE 21 TOTAL SETS OF ELEMENTS WITH NODE INCREMENT OF 15 SET IS SELECTED ELEMENTS IN RANGE 129 TO 129 IN STEPS OF 1 MAXIMUM ELEMENT NUMBER $=149$

PREP7:

GENERATE 2 TOTAL SETS OF ELEMENTS WITH NODE INCREMENT OF 1 SET IS SELECTED ELEMENTS IN RANGE 129 TO 149 IN STEPS OF 1 MAXIMUM ELEMENT NUMBER $=170$

PREP7:

$\begin{array}{llllll}\text { ELEMENT } & 171 & 300 & 315 & 316 & 301\end{array}$

PREP7:

GENERATE 2 TOTAL SETS OF ELEMENTS WITH NODE INCREMENT OF 15 SET IS SELECTED ELEMENTS IN RANGE 171 TO 171 IN STEPS OF 1 MAXIMUM ELEMENT NUMBER $=172$

PREP7:

GENERATE 2 TOTAL SETS OF ELEMENTS WITH NODE INCREMENT OF 1 SET IS SELECTED ELEMENTS IN RANGE 171 TO 172 IN STEPS OF 1 MAXIMUM ELEMENT NUMBER $=174$

PREP7:

$\begin{array}{llllll}\text { ELEMENT } & 175 & 304 & 319 & 320 & 305\end{array}$

PREP7:

GENERATE 2 TOTAL SETS OF ELEMENTS WITH NODE INCREMENT OF 15 SET IS SELECTED ELEMENTS IN RANGE 175 TO 175 IN STEPS OF 1 MAXIMUM ELEMENT NUMBER $=176$

PREP7:

GENERATE 8 TOTAL SETS OF ELEMENTS WITH NODE INCREMENT OF 1 SET IS SELECTED ELEMENTS IN RANGE 175 TO 176 IN STEPS OF 1 MAXIMUM ELEMENT NUMBER $=190$

PREP7: 
PREP7:

GENERATE 2 TOTAL SETS OF ELEMENTS WITH NODE INCREMENT OF 15 SET IS SELECTED ELEMENTS IN RANGE 191 TO 191 IN STEPS OF 1 MAXIMUM ELEMENT NUMBER $=192$

PREP7:

GENERATE 2 TOTAL SETS OF ELEMENTS WITH NODE INCREMENT OF 1 SET IS SELECTED ELEMENTS IN RANGE 191 TO 192 IN STEPS OF 1 MAXIMUM ELEMENT NUMBER $=194$

PREP7:

ELEMENT $\quad 195 \quad 454 \quad 469 \quad 470 \quad 455$

PREP7:

GENERATE 2 TOTAL SETS OF ELEMENTS WITH NODE INCREMENT OF 15 SET IS SELECTED ELEMENTS IN RANGE 195 TO 195 IN STEPS OF 1 MAXIMUM ELEMENT NUMBER $=196$

PREP7:

GENERATE 8 TOTAL SETS OF ELEMENTS WITH NODE INCREMENT OF 1 SET IS SELECTED ELEMENTS IN RANGE 195 TO 196 IN STEPS OF 1 MAXIMUM ELEMENT NUMBER $=210$

PREP7:

ELEMENT $\quad 211 \quad 540 \quad 555 \quad 556 \quad 541$

PREP7:

GENERATE 2 TOTAL SETS OF ELEMENTS WITH NODE INCREMENT OF 15 SET IS SELECTED ELEMENTS IN RANGE 211 TO 211 IN STEPS OF 1 MAXIMUM ELEMENT NUMBER $=212$

PREP7:

GENERATE 2 TOTAL SETS OF ELEMENTS WITH NODE INCREMENT OF 1 SET IS SELECTED ELEMENTS IN RANGE 211 TO 212 IN STEPS OF 1 MAXIMUM ELEMENT NUMBER $=214$

PREP7:

ELEMENT $\quad 215 \quad 544 \quad 559 \quad 560 \quad 545$

PREP7: 


\section{HNF-SD-TWR-CN-002 \\ Rev. 0 \\ Appendix B}

GENERATE 2 TOTAL SETS OF ELEMENTS WITH NODE INCREMENT OF 15 SET IS SELECTED ELEMENTS IN RANGE 215 TO 215 IN STEPS OF 1 MAXIMUM ELEMENT NUMBER $=216$

PREP7:

GENERATE 8 TOTAL SETS OF ELEMENTS WITH NODE INCREMENT OF 1 SET IS SELECTED ELEMENTS IN RANGE 215 TO 216 IN STEPS OF 1 MAXIMUM ELEMENT NUMBER $=230$

PREP7:

REAL CONSTANT NUMBER $=.6$

PREP7:

GENERATE 3 TOTAL SETS OF NODES WITH INCREMENT 2000 SET IS SELECTED NODES IN RANGE 303 TO 618 IN STEPS OF 15 GEOMETRY INCREMENTS ARE $0.00000 E+000.00000 E+00-5.4550 \quad$ SPACING $=1.0000$

PREP7:

GENERATE 3 TOTAL SETS OF NODES WITH INCREMENT 2000 SET IS SELECTED NODES IN RANGE 313 TO 628 IN STEPS OF 15 GEOMETRY INCREMENTS ARE $0.00000 \mathrm{E}+000.00000 \mathrm{E}+00-5.4550 \quad$ SPACING $=1.0000$

PREP7:

GENERATE 3 TOTAL SETS OF NODES WITH INCREMENT 2000 SET IS SELECTED NODES IN RANGE 315 TO 329 IN STEPS OF 1 GEOMETRY INCREMENTS ARE $0.00000 E+000.00000 E+00-5.4550 \quad$ SPACING $=1.0000$

PREP7:

GENERATE 3 TOTAL SETS OF NODES WITH INCREMENT 2000 SET IS SELECTED NODES IN RANGE 465 TO 479 IN STEPS OF 1 GEOMETRY INCREMENTS ARE $0.00000 E+000.00000 E+00-5.4550 \quad$ SPACING $=1.0000$

PREP7:

GENERATE 3 TOTAL SETS OF NODES WITH INCREMENT 2000 SET IS SELECTED NODES IN RANGE 555 TO 569 IN STEPS OF 1 GEOMETRY INCREMENTS ARE $0.00000 E+000.00000 E+00-5.4550 \quad$ SPACING $=1.0000$

PREP7:

$\begin{array}{llllll}\text { ELEMENT } & 231 & 303 & 318 & 2318 & 2303\end{array}$

PREP7:

GENERATE 21 TOTAL SETS OF ELEMENTS WITH NODE INCREMENT OF 15 SET IS SELECTED ELEMENTS IN RANGE 231 TO 231 IN STEPS OF 1 
HNF-SD-TWR-CN-002

Rev. 0

Appendix B

MAXIMUM ELEMENT NUMBER $=251$

PREP7:

GENERATE 2 TOTAL SETS OF ELEMENTS WITH NODE INCREMENT OF 2000 SET IS SELECTED ELEMENTS IN RANGE 23.1 TO 251 IN STEPS OF 1 MAXIMUM ELEMENT NUMBER $=272$

PREP7:

$\begin{array}{llllll}\text { ELEMENT } & 273 & 313 & 328 & 2328 & 2313\end{array}$

PREP7:

GENERATE 21 TOTAL SETS OF ELEMENTS WITH NODE INCREMENT OF 15 SET IS SELECTED ELEMENTS IN RANGE 273 TO 273 IN STEPS OF 1 MAXIMUM ELEMENT NUMBER $=293$

PREP7:

GENERATE 2 TOTAL SETS OF ELEMENTS WITH NODE INCREMENT OF 2000 . SET IS SELECTED ELEMENTS IN RANGE 273 TO 293 IN STEPS OF 1 MAXIMUM ELEMENT NUMBER $=314$

PREP7:

$\begin{array}{llllll}\text { ELEMENT } & 315 & 315 & 316 & 2316 & 2315\end{array}$

PREP7:

GENERATE 13 TOTAL SETS OF ELEMENTS WITH NODE INCREMENT OF 1 SET IS SELECTED ELEMENTS IN RANGE 315 TO 315 IN STEPS OF 1 MAXIMUM ELEMENT NUMBER $=327$

PREP7:

GENERATE 2 TOTAL SETS OF ELEMENTS WITH NODE INCREMENT OF 2000 SET IS SELECTED ELEMENTS IN RANGE 315 TO 327 IN STEPS OF 1 MAXIMUM ELEMENT NUMBER $=340$

PREP7:

$\begin{array}{llllll}\text { ELEMENT } & 341 & 465 & 466 & 2466 & 2465\end{array}$

PREP7:

GENERATE 13 TOTAL SETS OF ELEMENTS WITH NODE INCREMENT OF 1 SET IS SELECTED ELEMENTS IN RANGE 341 TO 341 IN STEPS OF 1 MAXIMUM ELEMENT NUMBER $=353$

PREP7: 


\section{HNF-SD-TWR-CN-002 \\ Rev. 0 \\ Appendix B}

GENERATE 2 TOTAL SETS OF ELEMENTS WITH NODE INCREMENT OF 2000

SET IS SELECTED ELEMENTS IN RANGE 341 TO 353 IN STEPS OF 1

MAXIMUM ELEMENT NUMBER $=366$

PREP7:

$\begin{array}{llllll}\text { ELEMENT } & 367 & 555 & 556 & 2556 & 2555\end{array}$

PREP7:

GENERATE 13 TOTAL SETS OF ELEMENTS WITH NODE INCREMENT OF 1 SET IS SELECTED ELEMENTS IN RANGE 367 TO 367 IN STEPS OF 1 MAXIMUM ELEMENT NUMBER $=379$

PREP7:

GENERATE 2 TOTAL SETS OF ELEMENTS WITH NODE INCREMENT OF 2000

SET IS SELECTED ELEMENTS IN RANGE 367 TO 379 IN STEPS OF 1 MAXIMUM ELEMENT NUMBER $=392$

PREP7:

REAL CONSTANT NUMBER $=\quad 5$

PREP7:

GENERATE 2 TOTAL SETS OF NODES WITH INCREMENT 4000

SET IS SELECTED NODES IN RANGE 4303 TO 4618 IN STEPS OF 15

GEOMETRY INCREMENTS ARE $0.00000 E+00-4.0000 \quad 0.00000 E+00$ SPACING $=1.0000$

PREP7:

GENERATE 2 TOTAL SETS OF NODES WITH INCREMENT 5000

SET IS SELECTED NODES IN RANGE 4303 TO 4618 IN STEPS OF 15

GEOMETRY INCREMENTS ARE $0.00000 E+00 \quad 4.0000 \quad 0.00000 E+00$ SPACING $=1.0000$

PREP7:

GENERATE 2 TOTAL SETS OF NODES WITH INCREMENT 4000

SET IS SELECTED NODES IN RANGE 4313 TO 4628 IN STEPS OF 15

GEOMETRY INCREMENTS ARE $0.00000 E+00-4.0000 \quad 0.00000 E+00$ SPACING $=1.0000$

PREP7:

GENERATE 2 TOTAL SETS OF NODES WITH INCREMENT 5000

SET IS SELECTED NODES IN RANGE 4313 TO 4628 IN STEPS OF 15

GEOMETRY INCREMENTS ARE $0.00000 E+00 \quad 4.0000 \quad 0.00000 E+00$ SPACING $=1.0000$

PREP7:

GENERATE 2 TOTAL SETS OF NODES WITH INCREMENT 4000

SET IS SELECTED NODES IN RANGE 4315 TO 4316 IN STEPS OF 1 


$$
\begin{array}{r}
\text { HNF-SD-TWR-CN-002 } \\
\text { Rev. } 0 \\
\text { Appendix } \quad \text { B }
\end{array}
$$

GEOMETRY INCREMENTS ARE $-4.0000 \quad 0.00000 E+000.00000 E+00$ SPACING $=1.0000$

PREP7:

GENERATE 2 TOTAL SETS OF NODES WITH INCREMENT 5000

SET IS SELECTED NODES IN RANGE 4315 TO 4316 IN STEPS OF 1

GEOMETRY INCREMENTS ARE $4.0000 \quad 0.00000 E+00 \quad 0.00000 E+00$ SPACING $=1.0000$

PREP7:

GENERATE 2 TOTAL SETS OF NODES WITH INCREMENT 4000

SET IS SELECTED NODES IN RANGE 4320 TO 4326 IN STEPS OF 1

GEOMETRY INCREMENTS ARE $-4.0000 \quad 0.00000 \mathrm{E}+000.00000 \mathrm{E}+00$ SPACING $=1.0000$

PREP7:

GENERATE 2 TOTAL SETS OF NODES WITH INCREMENT 5000

SET IS SELECTED NODES IN RANGE 4320 TO 4326 IN STEPS OF 1

GEOMETRY INCREMENTS ARE $4.0000 \quad 0.00000 \mathrm{E}+00 \quad 0.00000 \mathrm{E}+00$ SPACING $=1.0000$

PREP7:

GENERATE 2 TOTAL SETS OF NODES WITH INCREMENT 4000

SET IS SELECTED NODES IN RANGE 4465 TO 4466 IN STEPS OF 1

GEOMETRY INCREMENTS ARE $-4.0000 \quad 0.00000 \mathrm{E}+00 \quad 0.00000 \mathrm{E}+00$ SPACING $=1.0000$

PREP7:

GENERATE 2 TOTAL SETS OF NODES WITH INCREMENT 5000

SET IS SELECTED NODES IN RANGE 4465 TO 4466 IN STEPS OF 1

GEOMETRY INCREMENTS ARE $4.0000 \quad 0.00000 E+000.00000 E+00$ SPACING $=1.0000$

PREP7:

GENERATE 2 TOTAL SETS OF NODES WITH INCREMENT 4000

SET IS SELECTED NODES IN RANGE 4470 TO 4476 IN STEPS OF 1

GEOMETRY INCREMENTS ARE $-4.0000 \quad 0.00000 E+000.00000 E+00$ SPACING $=1.0000$

PREP7:

GENERATE 2 TOTAL SETS OF NODES WITH INCREMENT 5000

SET IS SELECTED NODES IN RANGE 4470 TO 4476 IN STEPS OF 1

GEOMETRY INCREMENTS ARE $4.0000 \quad 0.00000 \mathrm{E}+000.00000 \mathrm{E}+00$ SPACING $=1.0000$

PREP7:

GENERATE 2 TOTAL SETS OF NODES WITH INCREMENT 4000

SET IS SELECTED NODES IN RANGE 4555 TO 4556 IN STEPS OF 1

GEOMETRY INCREMENTS ARE $-4.0000 \quad 0.00000 \mathrm{E}+000.00000 \mathrm{E}+00$ SPACING $=1.0000$

PREP7: 


$$
\begin{array}{r}
\text { HNF-SD-TWR-CN-002 } \\
\text { Rev. } 0 \\
\text { Appendix B }
\end{array}
$$

GENERATE 2 TOTAL SETS OF NODES WITH INCREMENT 5000

SET IS SELECTED NODES IN RANGE 4555 TO 4556 IN STEPS OF 7

GEOMETRY INCREMENTS ARE $4.0000 \quad 0.00000 \mathrm{E}+000.00000 \mathrm{E}+00 \mathrm{SPACING}=1.0000$

PREP7:

GENERATE 2 TOTAL SETS OF NODES WITH INCREMENT 4000

SET IS SELECTED NODES IN RANGE 4560 TO 4566 IN STEPS OF 1

GEOMETRY INCREMENTS ARE $-4.0000 \quad 0.00000 \mathrm{E}+000.00000 \mathrm{E}+00$ SPACING $=1.0000$

PREP7:

GENERATE 2 TOTAL SETS OF NODES WITH INCREMENT 5000

SET IS SELECTED NODES IN RANGE 4560 TO 4566 IN STEPS OF 1

GEOMETRY INCREMENTS ARE $4.0000 \quad 0.00000 E+00 \quad 0.00000 E+00$ SPACING $=1.0000$

PREP7:

$\begin{array}{llllll}\text { ELEMENT } & 393 & 4303 & 4318 & 8318 & 8303\end{array}$

PREP7:

GENERATE 21 TOTAL SETS OF ELEMENTS WITH NODE INCREMENT OF 15

SET IS SELECTED ELEMENTS IN RANGE 393 TO 393 IN STEPS OF 1

MAXIMUM ELEMENT NUMBER $=413$

PREP7:

$\begin{array}{llllll}\text { ELEMENT } & 414 & 4313 & 4328 & 8328 & 8313\end{array}$

PREP7:

GENERATE 21 TOTAL SETS OF ELEMENTS WITH NODE INCREMENT OF 15 SET IS SELECTED ELEMENTS IN RANGE 414 TO 414 IN STEPS OF 1 MAXIMUM ELEMENT NUMBER $=434^{\circ}$

PREP7:

$\begin{array}{llllll}\text { ELEMENT } & 435 & 4303 & 4318 & 9318 & 9303\end{array}$

PREP7:

GENERATE 21 TOTAL SETS OF ELEMENTS WITH NODE INCREMENT OF 15 SET IS SELECTED ELEMENTS IN RANGE 435 TO 435 IN STEPS OF 1 MAXIMUM ELEMENT NUMBER $=455$

PREP7:

ELEMENT $\quad 456 \quad 4313 \quad 4328 \quad 9328 \quad 9313$

PREP7: 


\section{HNF-SD-TWR-CN-002 \\ Rev. 0 \\ Appendix B}

GENERATE 21 TOTAL SETS OF ELEMENTS WITH NODE INCREMENT OF 15

SET IS SELECTED ELEMENTS IN RANGE 456 TO 456 IN STEPS OF 1

MAXIMUM ELEMENT NUMBER $=476$

PREP7:

ELEMENT $\quad 477 \quad 4315 \quad 4316 \quad 8316 \quad 8315$

PREP7:

ELEMENT $\quad 478 \quad 4315 \quad 4316 \quad 9316 \quad 9315$

PREP7:

ELEMENT $\quad 479 \quad 4316 \quad 8318 \quad 8303 \quad 8316$

PREP7:

ELEMENT $\quad 480 \quad 4316 \quad 8318 \quad 8333 \quad 9316$

PREP7:

$\begin{array}{llllll}\text { ELEMENT } & 481 & 9318 & 4320 & 8320 & 9303\end{array}$

PREP7:

ELEMENT $\quad 482 \quad 9318 \quad 4320 \quad 9320 \quad 9333$

PREP7:

$\begin{array}{llllll}\text { ELEMENT } & 483 & 4320 & 4321 & 8321 & 8320\end{array}$

PREP7:

GENERATE 6 TOTAL SETS OF ELEMENTS WITH NODE INCREMENT OF 1 * SET IS SELECTED ELEMENTS IN RANGE 483 TO 483 IN STEPS OF 1 MAXIMUM ELEMENT NUMBER $=488$

PREP7:

ELEMENT $\quad 489 \quad 4320 \quad 4321 \quad 9321 \quad 9320$

PREP7:

GENERATE 6 TOTAL SETS OF ELEMENTS WITH NODE INCREMENT OF 1 SET IS SELECTED ELEMENTS IN RANGE 489 TO 489 IN STEPS OF 1 MAXIMUM ELEMENT NUMBER $=494$

PREP7:

$\begin{array}{llllll}\text { ELEMENT } & 495 & 4326 & 8328 & 8313 & 8326\end{array}$ 
PREP7:

ELEMENT $\quad 496 \quad 4326 \quad 8328 \quad 8343 \quad 9326$

PREP7:

ELEMENT $\quad 497 \quad 4465 \quad 4466 \quad 8466 \quad 8465$

PREP7:

ELEMENT $\quad 498 \quad 4465 \quad 4466 \quad 9466 \quad 9465$

PREP7:

$\begin{array}{llllll}\text { ELEMENT } & 499 & 4466 & 8468 & 8453 & 8466\end{array}$

PREP7:

ELEMENT $\quad 500 \quad 4466 \quad 8468 \quad 8483 \quad 9466$

PREP7:

$\begin{array}{lllllll}\text { ELEMENT } & 501 & 9468 & 4470 & 8470 & 9453\end{array}$

PREP7:

ELEMENT $\quad 502 \quad 9468 \quad 4470 \quad 9470 \quad 9483$

PREP7:

$\begin{array}{llllll}\text { ELEMENT } & 503 & 4470 & 4471 & 8471 & 8470\end{array}$

PREP7:

GENERATE 6 TOTAL SETS OF ELEMENTS WITH NODE INCREMENT OF 1 SET IS SELECTED ELEMENTS IN RANGE 503 TO 503 IN STEPS OF 1 MAXIMUM ELEMENT NUMBER $=508$

PREP7:

ELEMENT $\quad 509 \quad 4470 \quad 4471 \quad 9471 \quad 9470$

PREP7:

GENERATE 6 TOTAL SETS OF ELEMENTS WITH NODE INCREMENT OF 1 SET IS SELECTED ELEMENTS IN RANGE 509 TO 509 IN STEPS OF 1 MAXIMUM ELEMENT NUMBER $=514$

PREP7:

$\begin{array}{llllll}\text { ELEMENT } & 515 & 4476 & 8478 & 8463 & 8476\end{array}$ 
PREP7:

$\begin{array}{llllll}\text { ELEMENT } & 516 & 4476 & 8478 & 8493 & 9476\end{array}$

PREP7:

$\begin{array}{lllllll}\text { ELEMENT } \quad 517 \quad 4555 & 4556 & 8556 & 8555\end{array}$

PREP7:

ELEMENT $\quad 518 \quad 4555 \quad 4556 \quad 9556 \quad 9555$

PREP7:

ELEMENT $\quad 519 \quad 4556 \quad 8558 \quad 8543 \quad 8556$

PREP7:

$\begin{array}{llllll}\text { ELEMENT } & 520 & 4556 & 8558 & 8573 & 9556\end{array}$

PREP7:

$\begin{array}{lllllll}\text { ELEMENT } & 521 & 9558 & 4560 & 8560 & 9543\end{array}$

PREP7:

$\begin{array}{llllll}\text { ELEMENT } & 522 & 9558 & 4560 & 9560 & 9573\end{array}$

PREP7:

$\begin{array}{llllll}\text { ELEMENT } & 523 \quad 4560 & 4561 & 8561 & 8560\end{array}$

PREP7:

GENERATE 6 TOTAL SETS OF ELEMENTS WITH NODE INCREMENT OF 1 SET IS SELECTED ELEMENTS IN RANGE 523 TO 523 IN STEPS OF 1 MAXIMUM ELEMENT NUMBER $=528$

PREP7:

ELEMENT $\quad 529 \quad 4560 \quad 4561 \quad 9561 \quad 9560$

PREP7:

GENERATE 6 TOTAL SETS OF ELEMENTS WITH NODE INCREMENT OF 1 SET IS SELECTED ELEMENTS IN RANGE 529 TO 529 IN STEPS OF 1 MAXIMUM ELEMENT NUMBER $=\mathbf{5 3 4}$

PREP7:

$\begin{array}{llllll}\text { ELEMENT } & 535 & 4566 & 8568 & 8553 & 8566\end{array}$ 
PREP7:

$\begin{array}{llllll}\text { ELEMENT } & 536 & 4566 & 8568 & 8583 & 9566\end{array}$

PREP7:

COORDINATE SYSTEM 13 DEFINITION. TYPE $=1$ (CYLINDRICAL) $X C, Y C, Z C=40.000 \quad 55.375 \quad 0.00000 E+00$

ANGLES $=0.00 \quad 0.00 \quad 0.00 \quad$ PARAMETERS $=1.000 \quad 1.000$

ORIENTATION $=\begin{array}{lllllllllll}1.00 & 0.00 & 0.00 & 0.00 & 1.00 & 0.00 & 0.00 & 0.00 & 1.00\end{array}$

ACTIVE COORDINATE SYSTEM SET TO 13 (CYLINDRICAL)

PREP7:

ACTIVE COORDINATE SYSTEM SET TOO 13 (CYLINDRICAL)

PREP7:

NODE $100 \mathrm{KCS}=13 \quad X, Y, Z=25.000 \quad 0.00000 E+000.10000 E-01$

PREP7:

NODE $108 \mathrm{KCS}=13 \quad X, Y, Z=25.000 \quad 90.000 \quad 0.10000 E-01$

PREP7:

FILL 7 POINTS BETWEEN NODE 100 AND NODE 108

START WITH NODE 101 AND INCREMENT BY 1

PREP7:

NODE $116 \mathrm{KCS}=13 \quad \mathrm{X}, \mathrm{Y}, Z=25.000 \quad 180.00 \quad 0.10000 \mathrm{E}-01$

PREP7:

FILL 7 POINTS BETWEEN NODE 108 AND NODE 116

START WITH NODE 109 AND INCREMENT BY 1

PREP7:

NODE $117 \mathrm{KCS}=13 \quad X, Y, Z=25.000 \quad-168.75 \quad 0.10000 E-01$

PREP7:

NODE $124 \mathrm{KCS}=13 \quad X, Y, Z=25.000 \quad-90.000 \quad 0.10000 E-01$

PREP7:

FILL 6 POINTS BETWEEN NODE 117 AND NODE 124

START WITH NODE 118 AND INCREMENT BY 1 


$$
\begin{array}{r}
\text { HNF-SD-TWR-CN-002 } \\
\text { Rev. } 0 \\
\text { Appendix B }
\end{array}
$$

PREP7:

NODE, $131 \mathrm{KCS}=13 \quad \mathrm{X}, \mathrm{Y}, Z=25.000 \quad-11.250 \quad 0.10000 \mathrm{E}-01$

PREP7:

FILL 6 POINTS BETWEEN NODE 124 AND NODE 131

START WITH NODE 125 AND INCREMENT BY 1

PREP7:

GENERATE 3 TOTAL SETS OF NODES WITH INCREMENT 32

SET IS SELECTED NODES IN RANGE 100 TO . 131 IN STEPS OF 1

GEOMETRY INCREMENTS ARE $2.0000 \quad 0.10000 \mathrm{E}-010.00000 \mathrm{E}+00$ SPACING $=1.0000$

PREP7:

ELEMENT TYPE SET TO 1

PREP7:

REAL CONSTANT NUMBER $=1$

PREP7:

$\begin{array}{llllll}\text { ELEMENT } & 537 & 100 & 132 & 133 & 101\end{array}$

PREP7:

GENERATE 31 TOTAL SETS OF ELEMENTS WITH NODE INCREMENT OF 1 SET IS SELECTED ELEMENTS IN RANGE 537 TO 537 IN STEPS OF 1 MAXIMUM ELEMENT NUMBER $=567$

PREP7:

$\begin{array}{llllll}\text { ELEMENT } & 568 & 131 & 163 & 132 & 100\end{array}$

PREP7:

GENERATE 2 TOTAL SETS OF ELEMENTS WITH NODE INCREMENT OF 32

SET IS SELECTED ELEMENTS IN RANGE 537 TO 568 IN STEPS OF $\cdot 1$ MAXIMUM ELEMENT NUMBER $=600$

PREP7:

GENERATE 2 TOTAL SETS OF NODES WITH INCREMENT 30000 SET IS SELECTED NODES IN RANGE 454 TO 462 IN STEPS OF 1 GEOMETRY INCREMENTS ARE $0.00000 E+000.00000 E+000.10000 E-01$ SPACING $=1.0000$

PREP7:

GENERATE 2 TOTAL SETS OF NODES WITH INCREMENT 30000 


$$
\begin{array}{r}
\text { HNF-SD-TWR-CN-002 } \\
\text { Rev. O } \\
\text { Appendix B }
\end{array}
$$

SET IS SELECTED NODES IN RANGE 334 TO 342 IN STEPS OF 1

GEOMETRY INCREMENTS ARE $0.00000 \mathrm{E}+000.00000 \mathrm{E}+000.10000 \mathrm{E}-01 \mathrm{SPACING}=1.0000$

PREP7:

GENERATE 2 TOTAL SETS OF NODES WITH INCREMENT 30000

SET IS SELECTED NODES IN RANGE 357 TO 447 IN STEPS OF 15

GEOMETRY INCREMENTS ARE $0.00000 E+000.00000 E+000.10000 E-01$ SPACING $=1.0000$

PREP7:

GENERATE 2 TOTAL SETS OF NODES WITH INCREMENT 30000

SET IS SELECTED NODES IN RANGE 349 TO 439 IN STEPS OF 15

GEOMETRY INCREMENTS ARE 0.00000E + 00 0.00000E + 00 0.10000E-01 SPACING $=1.0000$

PREP7:

ELEMENT $601 \quad 1643045830459 \quad 165$

PREP7:

GENERATE 4 TOTAL SETS OF ELEMENTS WITH NODE INCREMENT OF 1 SET IS SELECTED ELEMENTS IN RANGE 601 TO 601 IN STEPS OF 1 MAXIMUM ELEMENT NUMBER $=604$

PREP7:

ELEMENT $\quad 605 \quad 168 \quad 30462 \quad 30447 \quad 169$

PREP7:

$\begin{array}{llllll}\text { ELEMENT } & 606 & 169 & 30447 & 30432 & 170\end{array}$

PREP7:

$\begin{array}{llllll}\text { ELEMENT } & 607 & 170 & 30432 & 30417 & 171\end{array}$

PREP7:

$\begin{array}{llllll}\text { ELEMENT } & 608 & 171 & 30417 & 30402 & 172\end{array}$

PREP7:

$\begin{array}{llllll}\text { ELEMENT } & 609 & 172 & 30402 & 30387 & 173\end{array}$

PREP7:

$\begin{array}{llllll}\text { ELEMENT } & 610 & 173 & 30387 & 30372 & 174\end{array}$

PREP7:

$\begin{array}{llllll}\text { ELEMENT } & 611 & 174 & 30372 & 30357 & 175\end{array}$ 
HNF-SD-TWR-CN-002

Rev. 0

Appendix B

PREP7:

$\begin{array}{llllll}\text { ELEMENT } & 612 & 175 & 30357 & 30342 & 176\end{array}$

PREP7:

$\begin{array}{llllll}\text { ELEMENT } & 613 & 176 & 30342 & 30341 & 177\end{array}$

PREP7:

$\begin{array}{llllll}\text { ELEMENT } & 614 & 177 & 30341 & 30340 & 178\end{array}$

PREP7:

$\begin{array}{llllll}\text { ELEMENT } & 615 & 178 & 30340 & 30339 & 179\end{array}$

PREP7:

$\begin{array}{llllll}\text { ELEMENT } & 616 & 179 & 30339 & 30338 & 180\end{array}$

PREP7:

$\begin{array}{llllll}\text { ELEMENT } & 617 & 180 & 30338 & 30337 & 181\end{array}$

PREP7:

$\begin{array}{llllll}\text { ELEMENT } & 618 & 181 & 30337 & 30336 & 182\end{array}$

PREP7:

$\begin{array}{llllll}\text { ELEMENT } & 619 & 182 & 30336 & 30335 & 183\end{array}$

PREP7:

$\begin{array}{llllll}\text { ELEMENT } & 620 & 183 & 30335 & 30334 & 184\end{array}$

PREP7:

$\begin{array}{llllll}\text { ELEMENT } & 621 & 184 & 30334 & 30349 & 185\end{array}$

PREP7:

$\begin{array}{llllll}\text { ELEMENT } & 622 & 185 & 30349 & 30364 & 186\end{array}$

PREP7:

$\begin{array}{llllll}\text { ELEMENT } & 623 & 186 & 30364 & 30379 & 187\end{array}$

PREP7:

$\begin{array}{llllll}\text { ELEMENT } & 624 & 187 & 30379 & 30394 & 188\end{array}$ 
PREP7:

$\begin{array}{llllll}\text { ELEMENT } & 625 & 188 & 30394 & 30409 & 189\end{array}$

PREP7:

$\begin{array}{llllll}\text { ELEMENT } & 626 & 189 & 30409 & 30424 & 190\end{array}$

PREP7:

$\begin{array}{llllll}\text { ELEMENT } & 627 & 190 & 30424 & 30439 & 191\end{array}$

PREP7:

$\begin{array}{llllll}\text { ELEMENT } & 6.28 & 191 & 30439 & 30454 & 192\end{array}$

PREP7:

$\begin{array}{llllll}\text { ELEMENT } & 629 & 192 & 30454 & 30455 & 193\end{array}$

PREP7:

GENERATE 3 TOTAL SETS OF ELEMENTS WITH NODE INCREMENT OF 1

SET IS SELECTED ELEMENTS IN RANGE 629 TO 629 IN STEPS OF 1 MAXIMUM ELEMENT NUMBER $=631$

PREP7:

ELEMENT $\quad \begin{array}{lllll}632 & 195 & 30457 & 30458 & 164\end{array}$

PREP7:

ACTIVE COORDINATE SYSTEM SET TO O (CARTESIAN)

PREP7:

COUPLED SET $=1$ DIRECTION $=\mathrm{UZ}$ TOTAL NODES $=2$ NODES ADDED $=37230372$

MAXIMUM COUPLED SET NUMBER $=1$

PREP7:

COUPLED SET $=2$ DIRECTION $=U Z$ TOTAL NODES $=2$ NODES ADDED $=43230432$

MAXIMUM COUPLED SET NUMBER $=2$

PREP7:

COUPLED SET $=3$ DIRECTION $=$ UZ TOTAL NODES $=2$ NODES ADDED $=45630456$

MAXIMUM COUPLED SET NUMBER $=3$ 
PREP7:

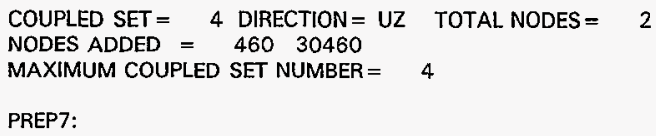

PREP7:

COUPLED SET $=11$ DIRECTION $=U X \quad$ TOTAL NODES $=2$ NODES ADDED $=45630456$

MAXIMUM COUPLED SET NUMBER $=11$

PREP7:

COUPLED SET $=12$ DIRECTION $=U X \quad$ TOTAL NODES $=2$ NODES ADDED $=46030460$ 
HNF-SD-TWR-CN-002

Rev. 0 Appendix B

MAXIMUM COUPLED SET NUMBER $=12$

PREP7:

COUPLED SET $=13$ DIRECTION $=U$ UX TOTAL NODES $=2$ NODES ADDED $=36430364$

MAXIMUM COUPLED SET NUMBER $=13$

PREP7:

COUPLED SET $=14$ DIRECTION $=U X$ TOTAL NODES $=2$ NODES ADDED $=42430424$

MAXIMUM COUPLED SET NUMBER $=14$

PREP7:

COUPLED SET $=15$ DIRECTION $=U X$ TOTAL NODES $=2$ NODES ADDED $=33630336$

MAXIMUM COUPLED SET NUMBER $=15$

PREP7:

COUPLED SET $=16$ DIRECTION $=$ UX TOTAL NODES $=2$ NODES ADDED $=34030340$

MAXIMUM COUPLED SET NUMBER $=16$

PREP7:

COUPLED SET $=17$ DIRECTION $=$ UY TOTAL NODES $=2$ NODES ADDED $=37230372$

MAXIMUM COUPLED SET NUMBER $=17$

PREP7:

COUPLED SET $=18$ DIRECTION $=$ UY TOTAL NODES $=2$ NODES ADDED $=43230432$

MAXIMUM COUPLED SET NUMBER $=18$

PREP7:

COUPLED SET $=19$ DIRECTION $=$ UY TOTAL NODES $=2$ NODES ADDED $=45630456$

MAXIMUM COUPLED SET NUMBER $=19$

PREP7:

COUPLED SET $=20$ DIRECTION $=$ UY TOTAL NODES $=2$ NODES ADDED $=46030460$

MAXIMUM COUPLED SET NUMBER $=20$

PREP7: 
HNF-SD-TWR-CN-002

Rev. 0

Appendix B

COUPLED SET $=21$ DIRECTION $=$ UY TOTAL NODES $=2$

NODES ADDED $=36430364$

MAXIMUM COUPLED SET NUMBER $=21$

PREP7:

COUPLED SET $=22$ DIRECTION $=$ UY TOTAL NODES $=2$

NODES ADDED $=42430424$

MAXIMUM COUPLED SET NUMBER $=22$

PREP7:

COUPLED SET $=23$ DIRECTION $=$ UY TOTAL NODES $=2$

NODES ADDED $=33630336$

MAXIMUM COUPLED SET NUMBER $=23$

PREP7:

COUPLED SET $=24$ DIRECTION $=$ UY TOTAL NODES $=2$ NODES ADDED $=34030340$

MAXIMUM COUPLED SET NUMBER $=24$

PREP7:

ELEMENT TYPE 5 IS COMBIN14 SPRING-DAMPER

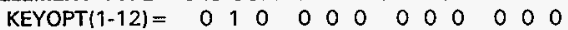

CURRENT NODAL DOF SET IS UX UY UZ ROTX ROTY ROTZ

THREE-DIMENSIONAL MODEL

PREP7:

REAL. CONSTANT SET 12 ITEMS 1 TO 6

$10.000 \quad 0.00000 E+00 \quad 0.00000 E+00 \quad 0.00000 E+00 \quad 0.00000 E+00 \quad 0.00000 E+00$

PREP7:

ELEMENT TYPE SET TO 5

PREP7:

REAL CONSTANT NUMBER $=12$

PREP7:

GENERATE 2 TOTAL SETS OF NODES WITH. INCREMENT 6000

SET IS SELECTED NODES IN RANGE 4303 TO 4313 IN STEPS OF 10

GEOMETRY INCREMENTS ARE-0.10000E-01 $0.00000 \mathrm{E}+000.00000 \mathrm{E}+00$ SPACING $=1.0000$

PREP7:

ELEMENT $\quad 633 \quad 4303 \quad 10303$ 


\section{HNF-SD-TWR-CN-002 \\ Rev. 0 \\ Appendix B}

PREP7:

ELEMENT $\quad 634 \quad 4313 \quad 10313$

PREP7:

GENERATE 2 TOTAL SETS OF NODES WITH INCREMENT 6000

SET IS SELECTED NODES IN RANGE 4618.TO 4628 IN STEPS OF 10

GEOMETRY INCREMENTS ARE $0.10000 E-010.00000 E+000.00000 E+00$ SPACING $=1.0000$

PREP7:

ELEMENT $\quad 635 \quad 4618 \quad 10618$

PREP7:

ELEMENT $\quad 636 \quad 4628 \quad 10628$

PREP7:

ELEMENT TYPE 6 IS COMBIN14 SPRING-DAMPER

$\operatorname{KEYOPT}(1-12)=0 \begin{array}{llllllllllll}0 & 2 & 0 & 0 & 0 & 0 & 0 & 0 & 0 & 0 & 0 & 0\end{array}$

CURRENT NODAL DOF SET IS UX UY UZ ROTX ROTY ROTZ

THREE-DIMENSIONAL MODEL

PREP7:

REAL CONSTANT SET 13 ITEMS 1 TO 6

$10.000 \quad 0.00000 E+00 \quad 0.00000 E+00 \quad 0.00000 E+00 \quad 0.00000 E+00 \quad 0.00000 E+00$

PREP7:

ELEMENT TYPE SET TO 6

PREP7:

REAL CONSTANT NUMBER $=13$

PREP7:

GENERATE 2 TOTAL SETS OF NODES WITH INCREMENT 6000

SET IS SELECTED NODES IN RANGE 4465 TO 4555 IN STEPS OF 90

GEOMETRY INCREMENTS ARE $0.00000 E+00-0.10000 E-010.00000 E+00$ SPACING $=1.0000$

PREP7:

ELEMENT $\quad 637 \quad 4465 \quad 10465$

PREP7:

ELEMENT $638 \quad 455510555$ 
HNF-SD-TWR-CN-002

Rev. 0

Appendix B

PREP7:

GENERATE 2 TOTAL SETS OF NODES WITH INCREMENT 6000

SET IS SELECTED NODES IN RANGE 4479 TO 4569 IN STEPS OF 90

GEOMETRY INCREMENTS ARE $0.00000 \mathrm{E}+000.10000 \mathrm{E}-010.00000 \mathrm{E}+00 \mathrm{SPACING}=1.0000$

PREP7:

ELEMENT $639 \quad 4479 \quad 10479$

PREP7:

ELEMENT $640^{\circ} 456910569$

PREP7:

SELECT FOR ITEM =NODE COMPONENT =

IN RANGE 10303 TO 10313 STEP 10

2 NODES (OF 774 DEFINED) SELECTED BY NSEL COMMAND.

PREP7:

ALSO SELECT FOR ITEM = NODE COMPONENT $=$

IN RANGE 10618 TO 10628 STEP 10

4 NODES (OF 774 DEFINED) SELECTED BY NSEL COMMAND.

PREP7:

ALSO SELECT FOR ITEM $=$ NODE COMPONENT = IN RANGE 10465 TO 10555 STEP 90

6 NODES (OF 774 DEFINED) SELECTED BY NSEL COMMAND.

PREP7:

ALSO SELECT FOR ITEM $=$ NODE COMPONENT $=$ IN RANGE 10479 TO 10569 STEP 90

8 NODES (OF 774 DEFINED) SELECTED BY NSEL COMMAND.

PREP7:

SPECIFIED CONSTRAINT UX FOR SELECTED NODES $\quad 1$ TO $30462 \mathrm{BY} \quad 1$

REAL $=0.000000000 E+00 \quad I M A G=0.000000000 E+00$

ADDITIONAL DOFS $=$ UY UZ ROTX ROTY ROTZ

PREP7:

SELECT ALL ENTITIES OF TYPE= ALL AND BELOW 


\title{
HNF-SD-TWR-CN-002 \\ Rev. 0 \\ Appendix B
}

\begin{abstract}
ALL SELECT FOR ITEM $=$ VOLU COMPONENT = IN RANGE OTO OSTEP 1

O VOLUMES IOF O DEFINED) SELECTED BY VSEL COMMAND.
\end{abstract}

ALL SELECT FOR ITEM = AREA COMPONENT = IN RANGE O TO O STEP 1

O AREAS (OF O DEFINED) SELECTED BY ASEl COMMAND.

ALL SELECT FOR ITEM = LINE COMPONENT = IN RANGE O TO O STEP 1

0 LINES (OF O DEFINED) SELECTED BY LSEL COMMAND.

ALL SELECT FOR ITEM $=$ KP COMPONENT $=$ IN RANGE O TO O STEP 1

O KEYPOINTS (OF O DEFINED) SELECTED BY KSEL COMMAND.

ALL SELECT FOR ITEM = ELEM COMPONENT = IN RANGE 1 TO 640 STEP

640 ELEMENTS IOF 640 DEFINEDI SELECTED BY ESEL COMMAND.

$\begin{array}{lll}\text { ALL SELECT } & \text { FOR ITEM }=\text { NODE COMPONENT }= \\ \text { IN RANGE } & 1 \text { TO } 30462 \text { STEP } & 1\end{array}$

774 NODES IOF 774 DEFINED) SELECTED BY NSEL COMMAND.

PREP7:

ACTIVE COORDINATE SYSTEM SET TO O (CARTESIAN)

PREP7:

GENERATE 2 TOTAL SETS OF NODES WITH INCREMENT 7000

SET IS SELECTED NODES IN RANGE 4315 TO 4329 IN STEPS OF 1

GEOMETRY INCREMENTS ARE $0.00000 E+000.00000 E+00-0.10000 E-01$ SPACING $=1.0000$

PREP7:

GENERATE 2 TOTAL SETS OF NODES WITH INCREMENT 7000

SET IS SELECTED NODES IN RANGE 4465 TO 4479 IN STEPS OF 14

GEOMETRY INCREMENTS ARE $0.00000 E+000.00000 E+00-0.10000 E-01$ SPACING $=1.0000$

PREP7:

GENERATE 2 TOTAL SETS OF NODES WITH INCREMENT 7000

SET IS SELECTED NODES IN RANGE 4555 TO 4569 IN STEPS OF 14

GEOMETRY INCREMENTS ARE $0.00000 E+000.00000 E+00-0.10000 E-01$ SPACING $=1.0000$ 
PREP7:

GENERATE 2 TOTAL SETS OF NODES WITH INCREMENT 7000

SET IS SELECTED NODES IN RANGE 4618 TO 4628 IN STEPS OF 10

GEOMETRY INCREMENTS ARE $0.00000 \mathrm{E}+000.00000 \mathrm{E}+00-0.10000 \mathrm{E}-01 \mathrm{SPACING}=1.0000$

PREP7:

ELEMENT TYPE 2 IS CONTAC52 3-D INTERFACE

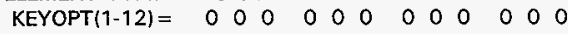

INOPR $=1$

CURRENT NODAL DOF SET IS UX UY UZ ROTX ROTY ROTZ THREE-DIMENSIONAL MODEL.

PREP7:

REAL CONSTANT SET 11 ITEMS 1 TO 6 $0.10000 E+08 \quad 0.00000 E+00 \quad 1.0000 \quad 0.00000 E+00 \quad 0.00000 E+00 \quad 0.00000 E+00$

PREP7:

REAL CONSTANT SET 20 ITEMS 1 TO 6

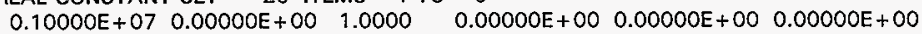

PREP7:

ELEMENT TYPE SET TO 2

PREP7:

REAL CONSTANT NUMBER = 11

PREP7:

ELEMENT $641 \quad 11315 \quad 4315$

PREP7:

GENERATE 15 TOTAL SETS OF ELEMENTS WITH NODE INCREMENT OF 1 SET IS SELECTED ELEMENTS IN RANGE 641 TO 641 IN STEPS OF 1 MAXIMUM ELEMENT NUMBER $=655$

PREP7:

ELEMENT $\quad 656 \quad 11465 \quad 4465$

PREP7:

ELEMENT $\quad 657 \quad 11479 \quad 4479$

PREP7: 
HNF-SD-TWR-CN-002

Rev. 0

Appendix B

$\begin{array}{llll}\text { ELEMENT } \quad 658 & 11555 \quad 4555\end{array}$

PREP7:

ELEMENT $\quad 659.11569 \quad 4569$

PREP7:

ELEMENT $\quad 660 \quad 11618 \quad 4618$

PREP7:

ELEMENT $\quad 661 \quad 11628 \quad 4628$

PREP7:

REAL CONSTANT NUMBER $=20$

PREP7:

$\begin{array}{llll}\text { ELEMENT } & 662 \quad 334 & 30334\end{array}$

PREP7:

GENERATE 2 TOTAL SETS OF ELEMENTS WITH NODE INCREMENT OF 1 SET IS SELECTED ELEMENTS IN RANGE 662 TO 662 IN STEPS OF 1 MAXIMUM ELEMENT NUMBER $=663$

PREP7:

ELEMENT $\quad 664 \quad 337 \quad 30337$

PREP7:

GENERATE 3 TOTAL SETS OF ELEMENTS WITH NODE INCREMENT OF 1 SET IS SELECTED ELEMENTS IN RANGE 664 TO 664 IN STEPS OF 1 MAXIMUM ELEMENT NUMBER $=666$

PREP7:

ELEMENT $\quad 667 \quad 341 \quad 30341$

PREP7:

GENERATE 2 TOTAL SETS OF ELEMENTS WITH NODE INCREMENT OF 1 SET IS SELECTED ELEMENTS IN RANGE 667 TO 667 IN STEPS OF 1 MAXIMUM ELEMENT NUMBER $=668$

PREP7:

ELEMENT $\quad 669 \quad 357 \quad 30357$ 
HNF-SD-TWR-CN-002

Rev. 0

Appendix B

PREP7:

ELEMENT $\quad 670 \quad 387 \quad 30387$

PREP7:

GENERATE 3 TOTAL SETS OF ELEMENTS WITH NODE INCREMENT OF 15 SET IS SELECTED ELEMENTS IN RANGE 670 TO $670 \mathrm{IN}$ STEPS OF 1 MAXIMUM ELEMENT NUMBER $=672$

PREP7:

$\begin{array}{llll}\text { ELEMENT } \quad 673 \quad 447 & 30447\end{array}$

PREP7:

ELEMENT $\quad 674 \quad 349 \quad 30349$

PREP7:

ELEMENT $\quad 675 \quad 379 \quad 30379$

PREP7:

GENERATE 3 TOTAL SETS OF ELEMENTS WITH NODE INCREMENT OF 15 SET IS SELECTED ELEMENTS IN RANGE 675 TO 675 IN STEPS OF 1 MAXIMUM ELEMENT NUMBER $=677$

PREP7:

ELEMENT $\quad 678 \quad 439 \quad 30439$

PREP7:

ELEMENT $\quad 679 \quad 454 \quad 30454$

PREP7:

GENERATE 2 TOTAL SETS OF ELEMENTS WITH NODE INCREMENT OF 1 SET IS SELECTED ELEMENTS IN RANGE 679 TO 679 IN STEPS OF 1 MAXIMUM ELEMENT NUMBER $=680$

PREP7:

ELEMENT $\quad 681 \quad 457 \quad 30457$

PREP7:

GENERATE 3 TOTAL SETS OF ELEMENTS WITH NODE INCREMENT OF 1 SET IS SELECTED ELEMENTS IN RANGE 681 TO 681 IN STEPS OF 1 MAXIMUM ELEMENT NUMBER $=683$ 
PREP7:

ELEMENT $\quad 684 \quad 461 \quad 30461$

PREP7:

GENERATE 2 TOTAL SETS OF ELEMENTS WITH NODE INCREMENT OF 1 SET IS SELECTED ELEMENTS IN RANGE 684 TO 684 IN STEPS OF 1 MAXIMUM ELEMENT NUMBER $=685$

PREP7:

SELECT FOR ITEM $=$ NODE COMPONENT $=$ IN RANGE 11315 TO 11329 STEP 1

15 NODES (OF 795 DEFINED) SELECTED BY NSEL COMMAND.

PREP7:

ALSO SELECT FOR ITEM = NODE COMPONENT $=$ IN RANGE 11465 TO 11479 STEP 14

17 NODES (OF 795 DEFINED) SELECTED BY NSEL COMMAND.

PREP7:

ALSO SELECT FOR ITEM = NODE COMPONENT = IN RANGE 11555 TO 11569 STEP 14

19 NODES (OF 795 DEFINED) SELECTED BY NSEL COMMAND.

PREP7:

ALSO SELECT FOR ITEM $=$ NODE COMPONENT $=$ IN RANGE 11618 TO 11628 STEP 10

21 NODES (OF 795 DEFINED) SELECTED BY NSEL COMMAND.

PREP7:

SPECIFIED CONSTRAINT UX FOR SELECTED NODES 1 TO $30462 \mathrm{BY} \quad 1$ $R E A L=0.000000000 E+00 \quad$ IMAG $=0.000000000 E+00$

ADDITIONAL DOFS $=$ UY UZ ROTX ROTY ROTZ

PREP7:

SELECT ALL ENTITIES OF TYPE = ALL AND BELOW

ALL SELECT FOR ITEM $=$ VOLU $\cdot$ COMPONENT $=$ IN RANGE OTO O STEP 1

0 VOLUMES (OF O DEFINED) SELECTED BY VSEL COMMAND. 


$$
\begin{aligned}
& \text { ALL SELECT FOR ITEM =AREA COMPONENT = } \\
& \text { IN RANGE O TO O STEP } 1
\end{aligned}
$$

$$
\begin{aligned}
& \text { ALL SELECT } \\
& \text { FOR ITEM }=\text { LINE COMPONENT }= \\
& \text { IN RANGE } \\
& \begin{array}{l}
\text { O TO } \quad \text { O STEP } \\
1
\end{array} \\
& 0 \text { LINES (OF } \quad \text { O DEFINED) SELECTED BY LSEL COMMAND. }
\end{aligned}
$$

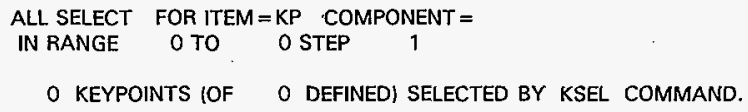


REAL CONSTANT NUMBER $=8$

PREP7:

NODE $20001 \mathrm{KCS}=15 \quad \mathrm{X}, \mathrm{Y}, \mathrm{Z}=-16.000 \quad-16.000 \quad 20.000$

PREP7:

NODE $20009 \mathrm{KCS}=15 \quad \mathrm{X}, \mathrm{Y}, \mathrm{Z}=16.000 \quad-16.000 \quad 20.000$

PREP7:

FILL 7 POINTS BETWEEN NODE 20001 AND NODE 20009

START WITH NODE 20002 AND INCREMENT BY 1

PREP7:

GENERATE 9 TOTAL SETS OF NODES WITH INCREMENT 9 SET IS SELECTED NODES IN RANGE 20001 TO 20009 IN STEPS OF 1

GEOMETRY INCREMENTS ARE $0.00000 E+00 \quad 4.0000 \quad 0.00000 E+00$ SPACING $=1.0000$

PREP7:

ELEMENT 68620001200022001120010

PREP7:

GENERATE 8 TOTAL SETS OF ELEMENTS WITH NODE INCREMENT OF 1 SET IS SELECTED ELEMENTS IN RANGE 686 TO 686 IN STEPS OF 1 MAXIMUM ELEMENT NUMBER $=693$

PREP7:

GENERATE 8 TOTAL SETS OF ELEMENTS WITH NODE INCREMENT OF 9 SET IS SELECTED ELEMENTS IN RANGE 686 TO 693 IN STEPS OF 1 MAXIMUM ELEMENT NUMBER $=749$

PREP7:

ACTIVE COORDINATE SYSTEM SET TO 13 (CYLINDRICAL)

PREP7:

NODE $20100 \mathrm{KCS}=13 \quad \mathrm{X}, \mathrm{Y}, \mathrm{Z}=25.000 \quad 0.00000 \mathrm{E}+00 \quad 20.000$

PREP7:

NODE $20108 \mathrm{KCS}=13 \quad X, Y, Z=25.000 \quad 90.000 \quad 20.000$

PREP7:

FILL 7 POINTS BETWEEN NODE 20100 AND NODE 20108 
HNF-SD-TWR-CN-002

Rev. 0

Appendix $B$

START WITH NODE 20101 AND INCREMENT BY 1

PREP7:

NODE $20116 \mathrm{KCS}=13 \quad \mathrm{X}, \mathrm{Y}, \mathrm{Z}=25.000 \quad 180.00 \quad 20.000$

PREP7:

FILL 7 POINTS BETWEEN NODE 20108 AND NODE 20116

START WITH NODE 20109 AND INCREMENT BY 1

PREP7:

NODE $20117 \mathrm{KCS}=13 \quad \mathrm{X}, \mathrm{Y}, Z=25.000 \quad-168.75 \quad 20.000$

PREP7:

NODE $20124 \mathrm{KCS}=13 \quad X, Y, Z=25.000 \quad-90.000 \quad 20.000$

PREP7:

FILL 6 POINTS BETWEEN NODE 20117 AND NODE 20124

START WITH NODE 20118 AND INCREMENT BY 1

PREP7:

NODE $20131 \mathrm{KCS}=13 \quad X, Y, Z=25.000 \quad-1.1 .250 \quad 20.000$

PREP7:

FILL 6 POINTS BETWEEN NODE 20124 AND NODE 20131

START WITH NODE 20125 AND INCREMENT BY 1

PREP7:

ELEMENT $\quad 750 \quad 20045201002010120054$

PREP7:

ELEMENT $751200542010120102 \quad 20063$

PREP7:

ELEMENT 75220063201022010320072

PREP7:

ELEMENT 75320072201032010420081

PREP7:

ELEMENT $\quad 754 \quad 20081201042010520080$ 
HNF-SD-TWR-CN-002

Rev. 0

Appendix B

PREP7:

ELEMENT $755 \quad 20080201052010620079$

PREP7:

ELEMENT $\quad 756 \quad 2007920106 \quad 20107 \quad 20078$

PREP7:

$\begin{array}{llllll}\text { ELEMENT } & 757 & 20078 & 20107 & 20108 & 20077\end{array}$

PREP7:

ELEMENT $758 \quad 20077201082010920076$

PREP7:

ELEMENT 75920076201092011020075

PREP7:

ELEMENT $760 \quad 20075 \quad 201102011120074$

PREP7:

ELEMENT $761 \quad 20074201112011220073$

PREP7:

ELEMENT $762 \quad 20073201122011320064$

PREP7:

ELEMENT $763 \quad 2006420113 \quad 2011420055$

PREP7:

ELEMENT $764 \quad 20055 \quad 201142011520046$

PREP7:

ELEMENT $\quad 765 \quad 20046 \quad 20115 \quad 20116 \quad 20037$

PREP7:

ELEMENT $766 \quad 20037 \quad 20116 \quad 2011720028$

PREP7:

ELEMENT $\quad 767 \quad 20028 \quad 2011720118 \quad 20019$ 
HNF-SD-TWR-CN-002

Rev. 0

Appendix B

PREP7:

ELEMENT $\quad 768 \quad 20019201182011920010$

PREP7:

ELEMENT 76920010201192012020001

PREP7:

ELEMENT $770 \quad 20001201202012120002$

PREP7:

ELEMENT $771 \quad 20002 \quad 20121 \quad 20122 \quad 20003$

PREP7:

ELEMENT $772 \quad 2000320122 \quad 2012320004$

PREP7:

ELEMENT $\quad 773 \quad 20004201232012420005$

PREP7:

ELEMENT $\quad 774 \quad 20005 \quad 201242012520006$

PREP7:

ELEMENT $775 \quad 20006 \quad 201252012620007$

PREP7:

ELEMENT $776 \quad 2000720126 \quad 2012720008$

PREP7:

ELEMENT $\quad 777 \quad 20008 \quad 20127 \quad 20128 \quad 20009$

PREP7:

ELEMENT $\quad 778 \quad 2000920128 \quad 2012920018$

PREP7:

ELEMENT $\quad \begin{array}{llllll}779 & 20018 & 20129 & 20130 & 20027\end{array}$

PREP7:

ELEMENT $\quad 780 \quad 20027 \quad 201302013120036$ 
PREP7:

ELEMENT 78120036201312010020045

PREP7:

GENERATE 2 TOTAL SETS OF NODES WITH INCREMENT 32

SET IS SELECTED NODES IN RANGE 20100 TO 20131 IN STEPS OF 1

GEOMETRY INCREMENTS ARE $4.0000 \quad 0.00000 \mathrm{E}+000.00000 \mathrm{O}+00$ SPACING $=1.0000$

PREP7:

ELEMENT $782 \quad 20100201322013320101$

PREP7:

GENERATE 31 TOTAL SETS OF ELEMENTS WITH NODE INCREMENT OF 1

SET IS SELECTED ELEMENTS IN RANGE 782 TO 782 IN STEPS OF 1

MAXIMUM ELEMENT NUMBER $=812$

PREP7:

ELEMENT $813 \quad 20131201632013220100$

PREP7:

ELEMENT TYPE 3 IS COMBIN4O COMBINATION

$\operatorname{KEYOPT}(1-12)=\begin{array}{lllllllllllll}0 & 0 & 3 & 0 & 0 & 0 & 0 & 0 & 0 & 0 & 0 & 0\end{array}$

CURRENT NODAL DOF SET IS UX UY UZ ROTX ROTY ROTZ

THREE-DIMENSIONAL MODEL.

PREP7:

REAL CONSTANT SET 9 ITEMS 1 TO 6

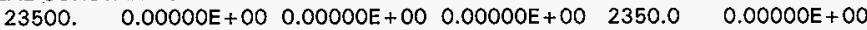

PREP7:

ELEMENT TYPE SET TO 3

PREP7:

REAL CONSTANT NUMBER $=9$

PREP7:

ELEMENT $\quad 814 \quad 132 \quad 20132$

PREP7:

GENERATE 32 TOTAL SETS OF ELEMENTS WITH NODE INCREMENT OF 1 
HNF-SD-TWR-CN-002

Rev. 0

Appendix B

SET IS SELECTED ELEMENTS IN RANGE 814 TO 814 IN STEPS OF 1

MAXIMUM ELEMENT NUMBER $=845$

PREP7:

SELECT FOR ITEM $=$ NODE COMPONENT $=$

IN RANGE 20132 TO 20156 STEP 8

4 NODES (OF 940 DEFINED) SELECTED BY NSEL COMMAND.

PREP7:

$\begin{array}{lllll}\text { SPECIFIED CONSTRAINT UX FOR SELECTED NODES } & 1 \text { TO } & 30462 \mathrm{BY} & 1\end{array}$

REAL $=0.000000000 E+00 \quad I M A G=0.000000000 E+00$

ADDITIONAL DOFS = UY ROTX ROTY ROTZ

PREP7:

SELECT ALL ENTITIES OF TYPE = ALL AND BELOW

ALL SELECT FOR ITEM $=$ VOLU COMPONENT $=$ IN RANGE OTO O STEP 1

0 VOLUMES (OF O DEFINED) SELECTED BY VSEL COMMAND.

ALL SELECT FOR ITEM = AREA COMPONENT $=$ IN RANGE O TO O STEP 1

O AREAS (OF O DEFINED) SELECTED BY ASEL COMMAND.

ALL. SELECT FOR ITEM $=$ LINE COMPONENT $=$ IN RANGE OTO O STEP 1

0 LINES (OF O DEFINED) SELECTED BY LSEL COMMAND.

ALL SELECT FOR ITEM $=K P \quad$ COMPONENT $=$ IN RANGE O TO O STEP 1

O KEYPOINTS (OF O DEFINED) SELECTED BY KSEL COMMAND.

ALL SELECT FOR ITEM $=$ ELEM COMPONENT $=$ IN RANGE 1 TO 845 STEP 1

845 ELEMENTS (OF 845 DEFINED) SELECTED BY ESEL COMMAND.

ALL SELECT FOR ITEM $=$ NODE COMPONENT $=$ IN RANGE 1 TO 30462 STEP 1

940 NODES (OF 940 DEFINED) SELECTED BY NSEL COMMAND.

PREP7: 
HNF-SD-TWR-CN-002

Rev. 0

Appendix B

ELEMENT TYPE 4 IS COMBIN4O COMBINATION

KEYOPT $(1-12)=\begin{array}{llllllllllll}1 & 0 & 3 & 0 & 0 & 2 & 0 & 0 & 0 & 0 & 0 & 0\end{array}$

CURRENT NODAL DOF SET IS UX UY UZ ROTX ROTY ROTZ

THREE-DIMENSIONAL MODEL

PREP7:

PARAMETER G $\quad=\quad 386.4000$

PREP7:

REAL CONSTANT SET 25 ITEMS 1 TO 6

$0.10000 E+06 \quad 0.00000 E+00 \quad 5.1760 \quad 720.00 \quad 0.00000 E+00 \quad 0.00000 E+00$

PREP7:

GENERATE 2 TOTAL SETS OF NODES WITH INCREMENT 3000

SET IS SELECTED NODES IN RANGE 20041 TO 20041 IN STEPS OF 1

GEOMETRY INCREMENTS ARE $0.00000 E+000.00000 E+00720.00 \quad$ SPACING $=1.0000$

PREP7:

ELEMENT TYPE SET TO 4

PREP7:

REAL CONSTANT NUMBER $=25$

PREP7:

ELEMENT $\quad 846 \quad 2004123041$

PREP7:

UNIFORM TEMPERATURE $=70.000($ TREF $=0.000)$

PREP7:

SELECT ALL ENTITIES OF TYPE = ALL AND BELOW

ALL SELECT $\cdot$ FOR ITEM $=$ VOLU COMPONENT $=$ IN RANGE 0 TO OSTEP 1.

O VOLUMES (OF O DEFINED) SELECTED BY VSEL COMMAND.

ALL SELECT FOR ITEM $=$ AREA COMPONENT $=$

IN RANGE O TO O STEP

0 AREAS (OF O DEFINED) SELECTED BY ASEL COMMAND.

ALL. SELECT FOR ITEM $=$ LINE COMPONENT $=$ 
IN RANGE OTO - OSTEP 1

0 LINES (OF O DEFINED] SELECTED BY LSEL COMMAND.

ALL SELECT FOR ITEM $=$ KP COMPONENT $=$ IN RANGE OTO OSTEP 1

O KEYPOINTS (OF O DEFINED) SELECTED BY KSEL COMMAND.

ALL SELECT FOR ITEM $=$ ELEM COMPONENT $=$ IN RANGE 1 TO 846 STEP 1

846 ELEMENTS IOF 846 . DEFINED) SELECTED BY ESEL COMMAND.

ALL SELECT FOR ITEM = NODE COMPONENT $=$ IN RANGE 1 TO 30462 STEP 1

941 NODES (OF 941 DEFINED) SELECTED BY NSEL COMMAND.

PREP7:

ALL CURRENT ANSYS DATA WRITTEN TO FILE NAME $=$ file.db FOR POSSIBLE RESUME FROM THIS POINT

PREP7:

$\cdots * *$ ROUTINE COMPLETED $\cdots * *$ CP $=\quad 10.480$

BEGIN:

***** ANSYS SOLUTION ROUTINE

SOLU_LS1:

PERFORM A TRANSIENT ANALYSIS

THIS WILL BE A NEW ANALYSIS

SOLU_LS1:

STEP BOUNDARY CONDITION KEY $=1$

SOLU_LS1:

$A C E L=0.00000 E+000.00000 E+00386.40$

SOLU_LS1:

SPECIFIED CONSTRAINT UZ FOR SELECTED NODES 23041 TO 23041 BY 
$\mathrm{REAL}=0.000000000 \mathrm{E}+00 \quad \mathrm{IMAG}=0.000000000 \mathrm{E}+00$

SOLU LS1:

DO NOT INCLUDE TRANSIENT EFFECTS FOR ALL DOFS THIS LOAD STEP

SOLU_LS1:

TIME $=0.10000 \mathrm{E}-04$

SOLU_LS1:

USE 2 SUBSTEP(S) THIS LOAD STEP FOR ALL DOFS

SOLU_LST:

USE A MAXIMUM OF 40 EQUILIBRIUM ITERATIONS EACH SUBSTEP SOLU_LS1:

WRITE ANSYS LOADS DATA AS FILE $=$ file.s01

SOLU_LS1:

INCLUDE TRANSIENT EFFECTS FOR ALL DOFS THIS LOAD STEP SOLU_LS1:

TIME $=1.9300$

SOLU_LS1:

USE 1200 SUBSTEP(S) THIS LOAD STEP FOR ALL DOFS

SOLU_LS1:

WRITE ALL ITEMS TO THE DATABASE WITH A FREQUENCY OF 5 FOR ALL APPLICABLE ENTITIES

SOLU_LS1:

USE AUTOMATIC TIME STEPPING THIS LOAD STEP

SOLU_LS1:

DELETE SPECIFIED CONSTRAINT UZ FOR SELECTED NODES

RANGE 23041 TO $23041 \mathrm{BY} \quad 1$

NUMBER OF SPECIFIED CONSTRAINTS DELETED $=\quad 1$

SOLU_LS1: 
WRITE ANSYS LOADS DATA AS FILE $=$ file .502

SOLU_LS1:

$\operatorname{TIME}=1.9800$

SOLU_LS1:

USE 500 SUBSTEP(S) THIS LOAD STEP FOR ALL DOFS

SOLU_LS1:

WRITE ALL ITEMS TO THE DATABASE WITH A FREQUENCY OF 3 FOR ALL APPLICABLE ENTITIES

SOLU_LS1:

USE A MAXIMUM OF 40 EQUILIBRIUM ITERATIONS EACH SUBSTEP

SOLU_LS1:

DO NOT USE AUTOMATIC TIME STEPPING THIS LOAD STEP

SOLU_LS1:

WRITE ANSYS LOADS DATA AS FILE $=$ file. .503

SOLU_LS1:

ANSYS REVISION $5.2 \quad 13: 36: 56 \quad 09 / 03 / 1997$

PRINTOUT RESUMED BY /GOP

Load step file number 1 . Begin solution ...

$* *$ ANSYS SOLVE COMMAND

*** WARNING *** CP= 12.080 TIME $=13: 36: 59$

Nodes $I$ and $\mathrm{J}$ of element 633 (COMBIN14) are not coincident.

*** WARNING *** CP= $\quad 12.080$ TIME $=13: 36: 59$

Nodes $I$ and $J$ of element 634 (COMBIN 14 ) are not coincident.

*** WARNING ***

$\mathrm{CP}=12.090$ TIME $=13: 36: 59$

Nodes I and $\mathrm{J}$ of element 635 ( COMBIN14) are not coincident.

*** WARNING *** CP= $\quad 12.090$ TIME $=13: 36: 59$

Nodes 1 and $\mathrm{J}$ of element 636 (COMBIN14) are nọt coincident.

*** WARNING *** CP= 12.090 TIME $=13: 36: 59$

Nodes $I$ and $J$ of element 637 (COMBIN14) are not coincident. 
Nodes I and $\mathrm{J}$ of element 638 ( COMBIN14) are not coincident.

*** WARNING *** CP= 12.090 TIME $=13: 36: 59$ Nodes I and $\mathrm{J}$ of element 639 ( COMBIN14) are not coincident.

** WARNING ** $\quad \mathrm{CP}=12.090$ TIME $=13: 36: 59$ Nodes $I$ and $J$ of element 640 ( COMBIN14) are not coincident.

*** WARNING *** CP= 12.160 TIME $=13: 36: 59$ Nodes $I$ and $J$ of element 814 ( COMBIN40) are not coincident.

*** WARNING *** CP $=12.160$ TIME $=13: 36: 59$ Nodes $\mathrm{I}$ and $\mathrm{J}$ of element 815 ( COMBIN40) are not coincident.

*** WARNING *** CP= $\quad 12.170$ TIME $=13: 36: 59$ Nodes $l$ and $J$ of element 816 (COMBIN40) are not coincident.

** WARNING *** CP= 12.170 TIME $=13: 36: 59$ Nodes $\mathrm{I}$ and $\mathrm{J}$ of element 817 (COMBIN40) are not coincident.

*** WARNING *** $\quad \mathrm{CP}=12.170$ TIME $=13: 36: 59$

Nodes $I$ and $J$ of element 818 (COMBIN40) are not coincident.

*** WARNING *** CP= $\quad 12.180$ TIME $=13: 36: 59$

Nodes $I$ and $J$ of element 819 (COMBIN40) are not coincident.

*** WARNING *** CP $=12.180$ TIME $=13: 36: 59$ Nodes $($ and $J$ of element 820 (COMBIN40) are not coincident.

*** WARNING *** CP= 12.180 TIME $=13: 36: 59$ Nodes $I$ and $J$ of element 821 (COMBIN40) are not coincident.

*** WARNING *** CP= $\quad 12.180$ TIME $=13: 36: 59$ Nodes $($ and $J$ of element 822 ( COMBIN40) are not coincident.

* * * WARNING *** CP $\quad$ CP 12.180 TIME $=13: 36: 59$

Nodes $\mathrm{I}$ and $\mathrm{J}$ of element 823 (COMBIN40 ) are not coincident.

** * WARNING *** CP= 12.180 TIME $=13: 36: 59$

Nodes $\mathrm{I}$ and $\mathrm{J}$ of element 824 ( COMBIN40) are not coincident.

*** WARNING *** CP= 12.180 TIME $=13: 36: 59$

Nodes I and $\mathrm{J}$ of element 825 ( COMBIN40) are not coincident.

Error messages discontinued after 20 messages were displayed.

More may exist. See (file.err ) for suppressed messages.

$* * * * * * * * * * * * * * * * * * * * * * * * * * * * * * * * * * * * * * * * * * * * * * * * * * * * * * * * * * * * * * * * * * * * * * * *$

*** NOTE *** CP $=12.210$ TIME $=13: 36: 59$

The model data was checked and warning messages were found. 
Please review output or errors file ( file.err ) for these warning messages.

\section{SOLUTION OPTIONS}

PROBLEM DIMENSIONALITY. . . . . . . . 3-D

DEGREES OF FREEDOM. . . . . UX UY UZ ROTX ROTY ROTZ

ANALYSIS TYPE . . . . . . . . . . TRANSIENT

SOLUTION METHOD. .............FULL

PLASTIC MATERIAL PROPERTIES INCLUDED. . . . . . YES

NEWTON-RAPHSON OPTION . . . . . . . . PROGRAM CHOSEN

* NOTE ** $\quad \mathrm{CP}=12.350$ TIME $=13: 36: 59$

This load step will be a static (steady-state) step.
** * NOTE
$\mathrm{CP}=12.520$ TIME $=13: 36: 59$

Results printout suppressed for interactive execute.

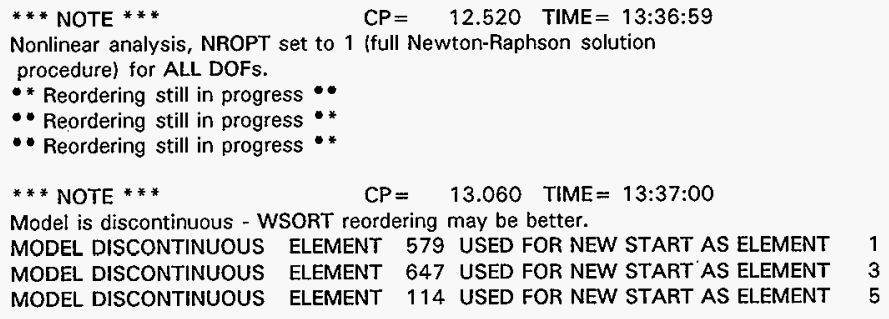

Nonlinear analysis, NROPT set to 1 (full Newton-Raphson solution procedure) for ALL DOFs.

-* Reordering still in progress "*

* Reordering still in progress **

- Reordering still in progress **

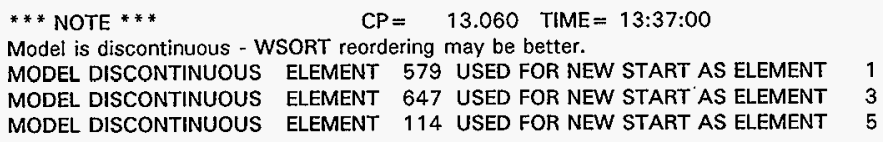

LOAD STEP OPTIONS

LOAD STEP NUMBER. . . . . . . . . 1

TIME AT END OF THE LOAD STEP. . . . . . . $0.10000 \mathrm{E}-04$

NUMBER OF SUBSTEPS. . . . . . . . . 2

MAXIMUM NUMBER OF EQUILIBRIUM ITERATIONS. . . 40

STEP CHANGE BOUNDARY CONDITIONS . . . . . Y YES

TRANSIENT (INERTIA) EFFECTS . . . . . . . . OFF

TERMINATE ANALYSIS IF NOT CONVERGED . . . . . YES (EXIT)

CONVERGENCE CONTROLS. . . . ....... USE DEFAULTS

INERTIA LOADS $X \quad Y \quad Z$

ACEL $\ldots \ldots \ldots \ldots .00000 E+000.00000 E+00 \quad 386.40$

COPY INTEGRATION POINT VALUES TO NODE . . . . . YES, FOR ELEMENTS WITH

ACTIVE MAT. NONLINEARITIES

PRINT OUTPUT CONTROLS . . . . . . . . . . NO PRINTOUT

DATABASE OUTPUT CONTROLS

ITEM FREQUENCY COMPONENT

ALL 5

ALL $\quad 3$ 
Element Formation Element $=480 \mathrm{Cum}$. Iter. $=1 \mathrm{CP}=24.160$

Time $=0.50000 \mathrm{E}-05 \mathrm{Load}$ Step $=1$ Substep $=1$ Equilibrium Iteration $=1$.

***** CENTROID, MASS, AND MASS MOMENTS OF INERTIA

\section{CALCULATIONS ASSUME ELEMENT MASS AT ELEMENT CENTROID}

TOTAL MASS $=19.851$

\section{CENTROID}

$X C=67.930$
$Y C=49.800$
$Z C=191.66$
MOM. OF INERTIA ABOUT ORIGIN
MOM. OF INERTIA ABOUT CENTROID

* * MASS SUMMARY BY ELEMENT TYPE ***

TYPE MASS

114.6755

$4 \quad 5.17598$

Range of element maximum matrix coefficients in global coordinates Maximum $=4.038371725 E+10$ at element 762 .

Minimum $=10$ at element 636 .

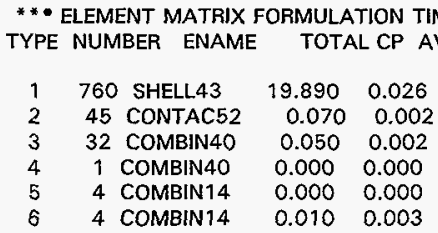

Time at end of element matrix formulation $\mathrm{CP}=33.4900017$.

Solution Preparation Element $=560$ Cum. Iter. $=1 \mathrm{CP}=34.410$

Time $=0.50000$ E-05 Load Step $=1$ Substep $=1$ Equilibrium Iteration $=1$. FORCE CONVERGENCE VALUE $=271.3$ CRITERION $=0.2713$

MOMENT CONVERGENCE VALUE $=0.0000 E+00$ CRITERION $=0.1000 E-02$

Estimated number of active DOF $=5101$.

Maximum wavefront $=372$.

Equation Solution Element $=670 \mathrm{Cum}$. Iter. $=1 \mathrm{CP}=45.010$

Time $=0.50000 \mathrm{E}-05$ Load Step $=1$ Substep $=1$ Equilibrium Iteration $=1$. 
HNF-SD-TWR-CN-002

Rev. 0

Appendix B

F Convergence Norm $=271.28$ Previous Norm $=271.28$

Time at end of matrix triangularization $\mathrm{CP}=47.5999985$.

Equation solver maximum pivot $=1.00419965 \mathrm{E}+11$ at node 20077 ROTY.

Equation solver minimum pivot $=23.0170983$ at node 156 ROTZ.

EQUIL ITER 1 COMPLETED. NEW TRIANG MATRIX. MAX DOF INC $=-0.8133 E-02$

Element Formation Element $=290 \mathrm{Cum}$. Iter. $=2 \mathrm{CP}=55.580$

Time $=0.50000$ E-05 Load Step $=1$ Substep $=1$ Equilibrium Iteration $=2$.

$F$ Convergence Norm $=271.28$ Previous Norm $=271.28$

Element Formation Element $=700 \mathrm{Cum}$. Iter. $=2 \mathrm{CP}=66.420$

Time $=0.50000$ E-05 Load Step $=1$ Substep $=1$ Equilibrium Iteration $=2$.

F Convergence Norm $=271.28$ Previous Norm $=271.28$

FORCE CONVERGENCE VALUE $=3476$. CRITERION $=1.962$

MOMENT CONVERGENCE VALUE $=0.7885 E-07$ CRITERION $=5.083<<<$ CONVERGED

- RESIDUAL INCREASED. PREV SOLN REMOVED. DESCENT PARAM SET TO 1.000

Element Formation Element $=200 \mathrm{Cum}$. Iter, $=2 \mathrm{CP}=77.080$

Time $=0.50000$ E-05 Load Step $=1$ Substep $=1$ Equilibrium Iteration $=2$.

$F$ Convergence Norm $=271.28$ Previous Norm $=271.28$

$M$ Convergence Norm $=0.78851 \mathrm{E}-07$ Previous Norm $=0.00000 \mathrm{E}+00$

Element Formation Element $=640 \mathrm{Cum}$. Iter. $=2 \mathrm{CP}=87.700$

Time $=0.50000 \mathrm{E}-05$ Load Step $=1$ Substep $=1$ Equilibrium Iteration $=2$.

F Convergence Norm $=271.28$ Previous Norm $=271.28$

$M$ Convergence Norm $=0.78851 \mathrm{E}-07$ Previous Norm $=0.00000 \mathrm{E}+00$

FORCE CONVERGENCE VALUE $=271.3 \quad$ CRITERION $=0.2713$

MOMENT CONVERGENCE VALUE $=0.0000 E+00$ CRITERION $=0.1000 \mathrm{E}-02$

Equation Solution Element $=340 \mathrm{Cum}$. Iter. $=2 \mathrm{CP}=98.450$

Time $=0.50000$ E-05 Load Step $=1$ Substep $=1$ Equilibrium Iteration $=2$.

$F$ Convergence Norm $=271.28$ Previous Norm $=271.28$

$M$ Convergence Norm $=0.00000 E+00$ Previous Norm $=0.78851 \mathrm{E}-07$

EQUIL ITER 2 COMPLETED. NEW TRIANG MATRIX. MAX DOF INC $=-0.8975 \mathrm{E}-02$

Element Formation Element $=10 \mathrm{Cum}$. Iter. $=3 \mathrm{CP}=108.870$

Time $=0.50000$ E-05 Load Step $=1$ Substep $=1$ Equilibrium Iteration $=3$.

F Convergence Norm $=271.28 \quad$ Previous Norm $=271.28$

$M$ Convergence Norm $=0.00000 E+00$ Previous Norm $=0.78851 \mathrm{E}-07$

Element Formation Element $=440 \mathrm{Cum}$. Iter. $=3 \mathrm{CP}=119.790$

Time $=0.50000 \mathrm{E}-05$ Load Step $=1$ Substep $=1$ Equilibrium Iteration $=3$.

F Convergence Norm $=271.28 \quad$ Previous Norm $=271.28$

$M$ Convergence $\cdot$ Norm $=0.00000 E+00$ Previous Norm $=0.78851 \mathrm{E}-07$

Element Formation Element $=820 \mathrm{Cum}$. Iter. $=3 \mathrm{CP}=130.340$

Time $=0.50000$ E-05 Load Step $=1$ Substep $=1$ Equilibrium Iteration $=3$.

F Convergence Norm $=271.28$ Previous Norm $=271.28$

$M$ Convergence Norm $=0.00000 E+00$ Previous Norm $=0.78851 \mathrm{E}-07$

FORCE CONVERGENCE VALUE $=124.3$ CRITERION $=1.908$

MOMENT CONVERGENCE VALUE $=0.1239 \mathrm{E}-06$ CRITERION $=9.243 \quad<<$ CONVERGED

Equation Solution Element $=570 \mathrm{Cum}$. Iter. $=3 \mathrm{CP}=140.940$

Time $=0.50000 E-05$ Load Step $=1$ Substep $=1$ Equilibrium Iteration $=3$.

F Convergence Norm $=124.34$ Previous Norm $=271.28$

$M$ Convergence Norm $=0.12391 \mathrm{E}-06$ Previous Norm $=0.00000 E+00$

EQUIL. ITER 3 COMPLETED. NEW TRIANG MATRIX. MAX DOF INC $=0.6531 E-04$

Element Formation Element $=190 \mathrm{Cum}$. Iter. $=4 \mathrm{CP}=151.090$

Time $=0.50000 \mathrm{E}-05$ Load Step $=1$ Substep $=1$ Equilibrium Iteration $=4$.

$F$ Convergence Norm $=124.34 \quad$ Previous Norm $=271.28$

$M$ Convergence Norm $=0.12391 \mathrm{E}-06$ Previous Norm $=0.00000 \mathrm{E}+00$ 
HNF-SD-TWR-CN-002

Rev. 0

Appendix B

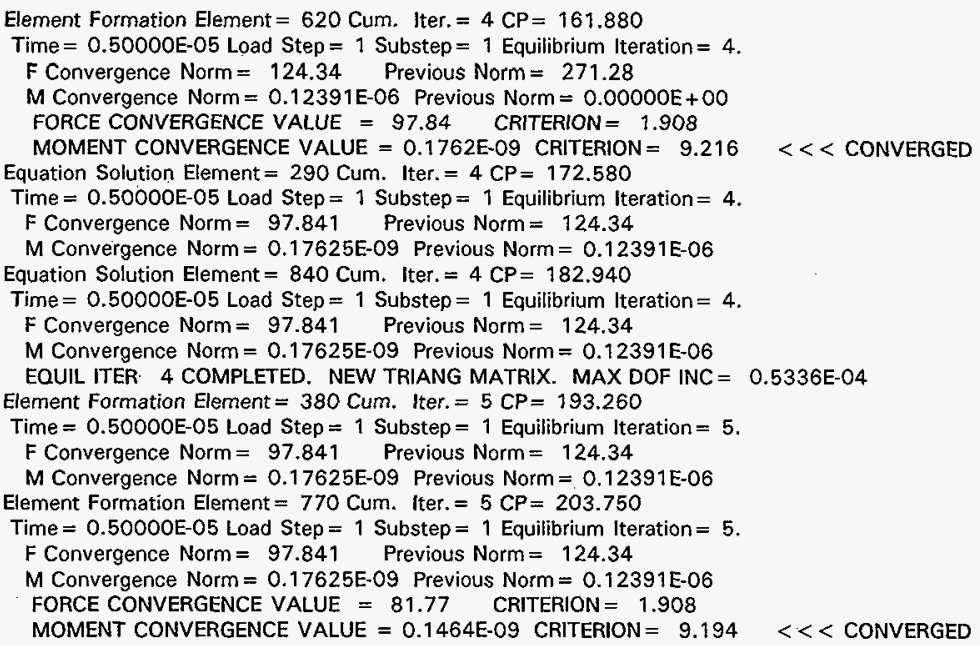

RESIDUAL DECREASED. DESCENT PARAMETER SET TO 0.2500

Equation Solution Element $=490 \mathrm{Cum}$. Iter. $=5 \mathrm{CP}=214.300$

Time $=0.50000 \mathrm{E}-05$ Load Step $=1$ Substep $=1$ Equilibrium Iteration $=5$.

F Convergence Norm $=81.771$ Previous Norm $=97.841$

$M$ Convergence Norm $=0.14641 \mathrm{E}-09$ Previous Norm $=0.17625 \mathrm{E}-09$

EQUIL ITER 5 COMPLETED. NEW TRIANG MATRIX. MAX DOF INC $=0.4508 E-04$

Element Formation Element $=130 \mathrm{Cum}$. Iter. $=6 \mathrm{CP}=224.430$

Time $=0.50000$ E-05 Load Step $=1$ Substep $=1$ Equilibrium Iteration $=6$.

$F$ Convergence Norm $=81.771 \quad$ Previous Norm $=97.841$

$M$ Convergence Norm $=0.14641 \mathrm{E}-09$ Previous Norm $=0.17625 \mathrm{E}-09$

Element Formation Element $=570 \mathrm{Cum}$, Iter. $=6 \mathrm{CP}=235.380$

Time $=0.50000$ E- 05 Load Step $=1$ Substep $=1$ Equilibrium Iteration $=6$.

$F$ Convergence Norm $=81.771 \quad$ Previous Norm $=97.841$

$M$ Convergence Norm $=0.14641 \mathrm{E}-09$ Previous Norm $=0.17625 \mathrm{E}-09$

FORCE CONVERGENCE VALUE $=72.68 \quad$ CRITERION $=1.909$

MOMENT CONVERGENCE VALUE $=0.1180 \mathrm{E}-09$ CRITERION $=9.176<<<$ CONVERGED

RESIDUAL DECREASED. DESCENT PARAMETER SET TO $0.6250 E-01$

Equation Solution Element $=180 \mathrm{Cum}$. Iter. $=6 \mathrm{CP}=245.960$

Time $=0.50000$ E-05 Load Step $=1$ Substep $=1$ Equilibrium Iteration $=6$.

F Convergence Norm $=72.681 \quad$ Previous Norm $=81.771$

$M$ Convergence Norm $=0.11799 \mathrm{E}-09$ Previous Norm $=0.14641 \mathrm{E}-09$

Equation Solution Element $=740 \mathrm{Cum}$. Iter. $=6 \mathrm{CP}=256.500$

Time $=0.50000 E-05$ Load Step $=1$ Substep $=1$ Equilibrium Iteration $=6$.

$F$ Convergence Norm $=72.681$ Previous Norm $=81.771$

$M$ Convergence Norm $=0.11799 \mathrm{E}-09$ Previous Norm $=0.14641 \mathrm{E}-09$

EOUIL. ITER 6 COMPLETED. NEW TRIANG MATRIX. MAX DOF INC $=0.1360 \mathrm{E}-03$

Element Formation Element $=340 \mathrm{Cum}$. Iter. $=7 \mathrm{CP}=267.020$ 
HNF-SD-TWR-CN-002

Rev. 0

Appendix B

Time $=0.50000 \mathrm{E}-05$ Load Step $=1$ Substep $=1$ Equilibrium Iteration $=7$.

$F$ Convergence Norm $=72.681 \quad$ Previous Norm $=81.771$

$M$ Convergence Norm $=0.11799 \mathrm{E}-09$ Previous Norm $=0.14641 \mathrm{E}-09$

Element Formation Element $=750$ Cum. Iter. $=7 \mathrm{CP}=277.970$

Time $=0.50000 \mathrm{E}-05$ Load Step $=1$ Substep $=1$ Equilibrium Iteration $=7$,

$F$ Convergence Norm $=72.681 \quad$ Previous Norm $=81.771$

$M$ Convergence Norm $=0.11799 \mathrm{E}-09$ Previous Norm $=0.14641 \mathrm{E}-09$

FORCE CONVERGENCE VALUE $=57.94 \quad$ CRITERION $=1.909$

MOMENT CONVERGENCE VALUE $=0.2925 E-09$ CRITERION $=9.131<<<$ CONVERGED

RESIDUAL DECREASED. DESCENT PARAMETER SET TO $0.1562 E-01$

Equation Solution Element $=440 \mathrm{Cum}$. Iter. $=7 \mathrm{CP}=288.050$

Time $=0.50000$ E-05 Load Step $=1$ Substep $=1$ Equilibrium Iteration $=7$.

$F$ Convergence Norm $=57.938$ Previous Norm $=72.681$

M Convergence Norm $=0.29248 \mathrm{E}-09$ Previous Norm $=0.11799 \mathrm{E}-09$

EQUIL ITER 7 COMPLETED. NEW TRIANG MATRIX. MAX DOF INC $=0.2990 E-03$

Element Formation Element $=90 \mathrm{Cum}$. Iter. $=8 \mathrm{CP}=298.350$

Time $=0.50000 \mathrm{E}-05$ Load $\mathrm{Step}=1$ Substep $=1$ Equilibrium Iteration $=8$.

F Convergence Norm $=57.938$ Previous Norm $=72.681$

$M$ Convergence Norm $=0.29248 \mathrm{E}-09$ Previous Norm $=0.11799 \mathrm{E}-09$

Element Formation Element $=510$ Cum. Iter. $=8 \mathrm{CP}=308.780$

Time $=0.50000 \mathrm{E}-05$ Load Step $=1$ Substep $=1$ Equilibrium Iteration $=8$.

F Convergence Norm $=57.938 \quad$ Previous Norm $=72.681$

$M$ Convergence Norm $=0.29248 \mathrm{E}-09$ Previous Norm $=0.11799 \mathrm{E}-09$

Solution Preparation Element $=710$ Cum. Iter. $=8 \mathrm{CP}=319.520$

Time $=0.50000 \mathrm{E}-05$ Load Step $=1$ Substep $=1$ Equilibrium Iteration $=8$.

$F$ Convergence Norm $=57.938$ Previous Norm $=72.681$

$M$ Convergence Norm $=0.29248 E-09$ Previous Norm $=0.11799 \mathrm{E}-09$

FORCE CONVERGENCE VALUE $=32.00 \quad$ CRITERION $=1.910$

MOMENT CONVERGENCE VALUE $=0.6824 \mathrm{E}-09$ CRITERION $=9.053 \quad<<$ CONVERGED

RESIDUAL DECREASED. DESCENT PARAMETER SET TO $0.0000 E+00$

Equation Solution Element $=690 \mathrm{Cum}$. Iter. $=8 \mathrm{CP}=330.440$

Time $=0.50000 E-05$ Load $S$ tep $=1$ Substep $=1$ Equilibrium Iteration $=8$.

$F$ Convergence Norm $=31.998 \quad$ Previous Norm $=57.938$

$M$ Convergence Norm $=0.68245 \mathrm{E}-09$ Previous Norm $=0.29248 \mathrm{E}-09$

EQUIL ITER 8 COMPLETED. NEW TRIANG MATRIX. MAX DOF INC $=0.2934 \mathrm{E}-03$

Element Formation Element $=300 \mathrm{Cum}$. Iter. $=9 \mathrm{CP}=340.940$

Time $=0.50000 \mathrm{E}-05$ Load $\mathrm{Step}=1$ Substep $=1$ Equilibrium Iteration $=9$.

$F$ Convergence Norm $=31.998 \quad$ Previous Norm $=57.938$

$M$ Convergence Norm $=0.68245 \mathrm{E}-09$ Previous Norm $=0.29248 \mathrm{E}-09$

Element Formation Element $=710 \mathrm{Cum}$. Iter. $=9 \mathrm{CP}=351.700$

Time $=0.50000 E-05$ Load Step $=1$ Substep $=1$ Equilibrium Iteration $=9$.

$F$ Convergence Norm $=31.998 \quad$ Previous Norm $=57.938$

$M$ Convergence Norm $=0.68245 \mathrm{E}-09$ Previous Norm $=0.29248 \mathrm{E}-09$

FORCE CONVERGENCE VALUE $=7.863$ CRITERION $=1.911$

MOMENT CONVERGENCE VALUE $=0.6815 E-09$ CRITERION $=8.989 \ll<$ CONVERGED

Equation Solution Element $=420 \mathrm{Cum}$. Iter. $=9 \mathrm{CP}=362.430$

Time $=0.50000 \mathrm{E}-05$ Load Step $=1$ Substep $=1$ Equilibrium Iteration $=9$.

F Convergence Norm $=7.8630$ Previous Norm $=31.998$

$M$ Convergence Norm $=0.68747 \mathrm{E}-09$ Previous Norm $=0.68245 \mathrm{E}-09$

EQUIL ITER 9 COMPLETED. NEW TRIANG MATRIX. MAX DOF INC $=0.9643 E-04$

Element Formation Element $=60 \mathrm{Cum}$. Iter. $=10 \mathrm{CP}=372.440$

Time $=0.50000$ E-05 Load Step $=1$ Substep $=1$ Equilibrium Iteration $=10$. 
F Convergence Norm $=7.8630 \quad$ Previous Norm $=31.998$

$M$ Convergence Norm $=0.68147 E-09$ Previous Norm $=0.68245 E-09$

Element Formation Element $=490$ Cum. Iter. $=10 \mathrm{CP}=383.160$

Time $=0.50000$ E-05 Load Step $=1$ Substep $=1$ Equilibrium Iteration $=10$.

$F$ Convergence Norm $=7.8630 \quad$ Previous Norm $=31.998$

M Convergence Norm $=0.68147 \mathrm{E}-09$ Previous Norm $=0.68245 \mathrm{E}-09$

Solution Preparation Element $=400 \mathrm{Cum}$. Iter, $=10 \mathrm{CP}=393.810$

Time $=0.50000 E-05$ Load Step $=1$ Substep $=1$ Equilibrium Iteration $=10$.

F Convergence Norm $=7.8630 \quad$ Previous Norm $=31.998$

$M$ Convergence Norm $=0.68147 E-09$ Previous Norm $=0.68245 E-09$

FORCE CONVERGENCE VALUE $=0.2128 \mathrm{E}-09$ CRITERION $=1.911$

MOMENT CONVERGENCE VALUE $=0.2888 E-09$ CRITERION $=8.969$

$<<<$ CONVERGED

$<<<$ CONVERGED

$>>>$ SOLUTION CONVERGED AFTER EQUILIBRIUM ITERATION 9

Element Output Element $=700 \mathrm{Cum}$. Iter. $=9 \mathrm{CP}=404.450$

Time $=0.50000$-05 Load Step $=1$ Substep $=1$ Equilibrium Iteration $=9$.

F Convergence Norm $=0.21279 \mathrm{E}-09$ Previous Norm $=7.8630$

M Convergence Norm $=0.28883 E-09$ Previous Norm $=0.68147 E-09$

* EleMENT RESUlt calculation times

TYPE NUMBER - ENAME TOTAL CP AVE CP

$\begin{array}{ccccc}1 & 760 \text { SHELL43 } & 11.370 & 0.015 \\ 2 & 45 \text { CONTAC52 } & 0.070 & 0.002 \\ 3 & 32 \text { COMBIN40 } & 0.010 & 0.000 \\ 4 & 1 \text { COMBIN40 } & 0.010 & 0.010 \\ 5 & 4 \text { COMBIN14 } & 0.000 & 0.000 \\ 6 & 4 \text { COMBIN14 } & 0.000 & 0.000\end{array}$

* * NODAL LOAD CALCULATION TIMES

TYPE NUMBER ENAME TOTAL CP AVE CP

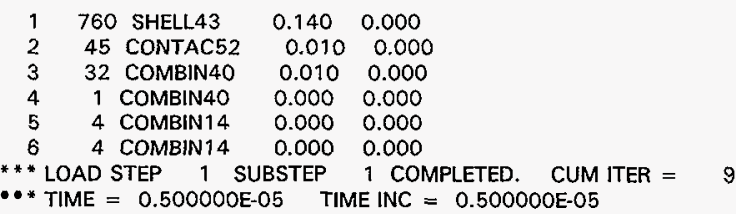

Element Formation Element $=170 \mathrm{Cum}$. Iter. $=10 \mathrm{CP}=412.530$

Time $=0.10000 E-04$ Load Step $=1$ Substep $=2$ Equilibrium Iteration $=1$.

F Convergence Norm $=0.21279 E-09$ Previous Norm $=7.8630$

$M$ Convergence Norm $=0.28883 \mathrm{E}-09$ Previous Norm $=0.68147 \mathrm{E}-09$

Element Formation Element $=600 \mathrm{Cum}$. Iter. $=10 \mathrm{CP}=422.920$

Time $=0.10000$ E-04 Load Step $=1$ Substep $=2$ Equilibrium Iteration $=1$.

F Convergence Norm $=0.21279 E-09$. Previous Norm $=7.8630$

$M$ Convergence Norm $=0.28883 E-09$ Previous Norm $=0.68147 \mathrm{E}-09$

FORCE CONVERGENCE VALUE $=0.2128 E-09$ CRITERION $=1.911$

MOMENT CONVERGENCE VALUE $=0.2888 \mathrm{E}-09$ CRITERION $=8.969$

Equation Solution Element $=250 \mathrm{Cum}$. Iter. $=10 \mathrm{CP}=433.300$

Time $=0.10000$ E -04 Load Step $=1$ Substep $=2$ Equilibrium Iteration $=1$. 
HNF-SD-TWR-CN-002

Rev. 0

Appendix B

F Convergence Norm $=0.21279 \mathrm{E}-09$ Previous Norm $=0.21279 \mathrm{E}-09$

$M$ Convergence Norm $=0.28883 E-09$ Previous Norm $=0.28883 E-09$

Equation Solution Element $=810 \mathrm{Cum}$. Iter. $=10 \mathrm{CP}=444.020$

Time $=0.10000 \mathrm{E}-04$ Load $\mathrm{Step}=1$ Stbstep $=2$ Equilibrium Iteration $=1$.

F Convergence Norm $=0.21279 \mathrm{E}-09$ Previous Norm $=0.21279 \mathrm{E}-09$

$M$ Convergence Norm $=0.28883 \mathrm{E}-09$ Previous Norm $=0.28883 \mathrm{E}-09$

EQUIL ITER 1 COMPLETED. NEW TRIANG MATRIX. MAX DOF INC $=-0.1685 \mathrm{E}-12$

Element Formation Element $=380$ Cum. Iter. $=11 \mathrm{CP}=454.690$

Time $=0.10000 \mathrm{E}-04$ Load Step $=1$ Substep $=2$ Equilibrium Iteration $=2$,

F Convergence Norm $=0.21279 \mathrm{E}-09$ Previous Norm $=0.21279 \mathrm{E}-09$

$M$ Convergence Norm $=0.28883 E-09$ Previous Norm $=0.28883 \mathrm{E}-09$

Element Formation Element $=770 \mathrm{Cum}$. Iter. $=11 \mathrm{CP}=465.190$

Time $=0.10000 E-04$ Load Step $=1$ Substep $=2$ Equilibrium Iteration $=2$.

$F$ Convergence Norm $=0.21279 \mathrm{E}-09$ Previous Norm $=0.21279 \mathrm{E}-09$

$\mathrm{M}$ Convergence Norm $=0.28883 \mathrm{E}-09$ Previous Norm $=0.28883 \mathrm{E}-09$

FORCE CONVERGENCE VALUE $=0.6190 \mathrm{E}-11$ CRITERION $=1.911$

MOMENT CONVERGENCE VALUE $=0.2395 E-11$ CRITERIO $N=8.969$

$>>>$ SOLUTION CONVERGED AFTER EQUILIBRIUM ITERATION 1

Element Output Element $=410 \mathrm{Cum}$. Iter. $=10 \mathrm{CP}=475.060$

Time $=0.10000 E-04$ Load Step $=1$ Substep $=2$ Equilibrium Iteration $=1$.

$F$ Convergence Norm $=0.61900 \mathrm{E}-11$ Previous Norm $=0.21279 \mathrm{E}-09$

$\mathrm{M}$ Convergence Norm $=0.23948 \mathrm{E}-11$ Previous Norm $=0.28883 \mathrm{E}-09$

*** LOAD STEP 1 SUBSTEP 2 COMPLETED. CUM ITER $=10$

$* *$ * TIME $=0.100000 \mathrm{E}-04 \quad$ TIME INC $=0.500000 \mathrm{E}-05$

** PROBLEM STATISTICS

ACTUAL NO. OF ACTIVE DEGREES OF FREEDOM $=5097$

R.M.S. WAVEFRONT SIZE $=270.8$

\author{
* * ANSYS BINARY FILE STATISTICS \\ BUFFER SIZE USED $=4096$ \\ 3.984 MB WRITTEN ON ELEMENT MATRIX FILE: file.emat \\ 11.688 MB WRITTEN ON ELEMENT SAVED DATA FILE: file.esav \\ 10.281 MB WRITTEN ON TRIANGULARIZED MATRIX FILE: file.tri \\ 2.000 MB WRITTEN ON RESULTS FILE: file.rSt \\ ANSYS REVISION $5.2 \quad 13: 36: 57 \quad 09 / 03 / 1997$
}

PRINTOUT RESUMED BY /GOP

Load step file number 2. Begin solution ...

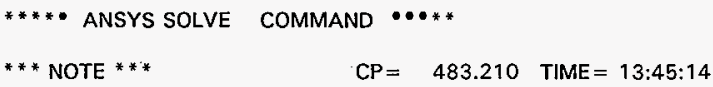

Results printout suppressed for interactive execute.

* * NOTE ** * CP= 483.210 TIME $=13: 45: 14$

Nonlinear analysis, NROPT set to 2 (modified Newton-Raphson solution procedure) for ALL DOFs.

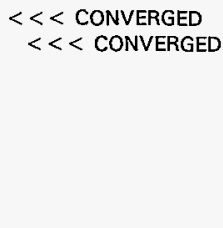




\section{LOAD STEP OPTIONS}

LOAD STEP NUMBER. . . . . . . . . . 2

TIME AT END OF THE LOAD STEP. . . . . 1.9300

AUTOMATIC TIME STEPPING ......... ON

INITIAL NUMBER OF SUBSTEPS . . . . . 1200

MAXIMUM NUMBER OF SUBSTEPS . . . . . 1200

MINIMUM NUMBER OF SUBSTEPS . . . . . . 1

MAXIMUM NUMBER OF EQUILIBRIUM ITERATIONS. . . . 40

STEP CHANGE BOUNDARY CONDITIONS ....... YES

TRANSIENT (INERTIA) EFFECTS

STRUCTURAL DOFS. .......... ON

TRANSIENT INTEGRATION PARAMETERS

ALPHA. . . . . . . . . . . . . . . . . . . .

DELTA. . . . . . . . . . . 0.50500

TERMINATE ANALYSIS IF NOT CONVERGED . . . . . YES (EXIT)

CONVERGENCE CONTROLS. ........... USE DEFAULTS

INERTIA LOADS $X \quad Y \quad Y \quad Z$

ACEL . . . . . . . 0.00000E +00 0.00000E +00 386.40

COPY INTEGRATION POINT VALUES TO NODE . . . . Y YES, FOR ELEMENTS WITH

ACTIVE MAT. NONLINEARITIES

PRINT OUTPUT CONTROLS . . . . . . . . . NO PRINTOUT

DATABASE OUTPUT CONTROLS

ITEM FREQUENCY COMPONENT

ALL 3

ALL 5

Element Formation Element $=10 \mathrm{Cum}$. Iter. $=11 \mathrm{CP}=484.900$

Time $=0.16183 \mathrm{E}-02$ Load Step $=2$ Substep $=1$ Equilibrium Iteration $=1$.

F Convergence Norm $=0.61900 \mathrm{E}-11$ Previous Norm $=0.21279 \mathrm{E}-09$

M Convergence Norm $=0.23948 \mathrm{E}-11$ Previous Norm $=0.28883 \mathrm{E}-09$

Element Formation Element $=440$ Cum. Iter. $=11 \mathrm{CP}=495.530$

Time $=0.16183$ E-02 Load Step $=2$ Substep $=1$ Equilibrium Iteration $=1$.

F Convergence Norm $=0.61900 \mathrm{E}-11$ Previous Norm $=0.21279 \mathrm{E}-09$

$\mathrm{M}$ Convergence $\cdot$ Norm $=0.23948 \mathrm{E}-11$ Previous Norm $=0.28883 \mathrm{E}-09$

Element Formation Element $=840 \mathrm{Cum}$. Iter. $=11 \mathrm{CP}=506.280$

Time $=0.16183 E-02$ Load Step $=2$ Substep $=1$ Equilibrium Iteration $=1$.

F Convergence Norm $=0.61900 \mathrm{E}-11$ Previous Norm $=0.21279 \mathrm{E}-09$

$\mathrm{M}$ Convergence Norm $=0.23948 \mathrm{E}-11$ Previous Norm $=0.28883 \mathrm{E}-09$

FORCE CONVERGENCE VALUE $=2000$. CRITERION $=2.766$

MOMENT CONVERGENCE VALUE $=0.2395 E-11$ CRITERION $=8.969$

Equation Solution Element $=590$ Cum. Iter. $=11 \mathrm{CP}=516.930$

Time $=0.16183 \mathrm{E}-02$ Load Step $=2$ Substep $=1$ Equilibrium Iteration $=1$. F Convergence Norm $=2000.0 \quad$ Previous Norm $=2000.0$

$M$ Convergence Norm $=0.23948 E-11$ Previous Norm $=0.23948 E-11$

EQUIL ITER 1 COMPLETED. NEW TRIANG MATRIX. MAX DOF INC $=-0.2524 E-03$

Element Formation Element $=200 \mathrm{Cum}$. Iter. $=12 \mathrm{CP}=527.010$

Time $=0.16183$ E-02 Load Step $=2$ Substep $=1$ Equilibrium Iteration $=2$.

F Convergence Norm $=2000.0 \quad$ Previous Norm $=2000.0$

M Convergence Norm $=0.23948 \mathrm{E}-11$ Previous Norm $=0.23948 \mathrm{E}-11$

Element Formation Element $=630 \mathrm{Cum}$. Iter. $=12 \mathrm{CP}=537.890$ 
HNF-SD-TWR-CN-002

Rev. 0

Appendix B

Time $=0.16183 \mathrm{E}-02$ Load Step $=2$ Substep $=1$ Equilibrium Iteration $=2$.

$F$ Convergence Norm $=2000.0$ Previous Norm $=2000.0$

$M$ Convergence Norm $=0.23948 \mathrm{E}-11$ Previous Norm $=0.23948 \mathrm{E}-11$

FORCE CONVERGENCE VALUE $=0.3734 \mathrm{E}-11$ CRITERION $=1.911<<<$ CONVERGED

MOMENT CONVERGENCE VALUE $=0.1871 \mathrm{E}-11$ CRITERION $=8.969<<<$ CONVERGED

$>>>$ SOLUTION CONVERGED AFTER EOUILIBRIUM ITERATION 1

ITERATION SUMMARY FOR INTERMEDIATE LOAD STEPS ARE DELETED.

Element Formation Element $=10 \mathrm{Cum}$. Iter. $=28 \mathrm{CP}=1768.670$

Time $=1.9300$ Load Step $=2$ Substep $=18$ Equilibrium Iteration $=1$.

F Convergence Norm $=0.13065 E-08$ Previous Norm $=0.15383 E+08$

$M$ Convergence Norm $=0.16021 \mathrm{E}-11$ Previous Norm $=0.17672 \mathrm{E}-11$

Element Formation Element $=450 \mathrm{Cum}$. Iter. $=28 \mathrm{CP}=1779.490$

Time $=1.9300$ Load Step $=2$ Substep $=18$ Equilibrium Iteration $=1$.

F Convergence Norm $=0.13065 E-08$ Previous Norm $=0.15383 E+08$

$M$ Convergence Norm $=0.16021 E-11$ Previous Norm $=0.17672 \mathrm{E}-11$

Solution Preparation Element $=10 \mathrm{Cum}$. Iter. $=28 \mathrm{CP}=1790.260$

Time $=1.9300$ Load Step $=2$ Substep $=18$ Equilibrium Iteration $=1$.

F Convergence Norm $=0.13065 E-08$ Previous Norm $=0.15383 E+08$

$M$ Convergence Norm $=0.16021 \mathrm{E}-11$ Previous Norm $=0.17672 \mathrm{E}-11$

FORCE CONVERGENCE VALUE $=0.1539 E+08$ CRITERION $=0.1539 E+05$

MOMENT CONVERGENCE VALUE $=0.1602 \mathrm{E}-11$ CRITERION $=8.969$

Equation Solution Element $=590$ Cum. Iter. $=28 \mathrm{CP}=1800.710$

Time $=1.9300$ Load Step $=2$ Substep $=18$ Equilibrium Iteration $=1$.

F Convergence Norm $=0.15391 \mathrm{E}+08$ Previous Norm $=0.15391 \mathrm{E}+08$

$\mathrm{M}$ Convergence Norm $=0.16021 \mathrm{E}-11$ Previous Norm $=0.16021 \mathrm{E}-11$

EQUIL ITER 1 COMPLETED. NEW TRIANG MATRIX. MAX DOF INC $=-0.7397$

Element Formation Element $=210 \mathrm{Cum}$. Iter. $=29 \mathrm{CP}=1811.090$

Time $=1.9300$ Load Step $=2$ Substep $=18$ Equilibrium Iteration $=2$.

F Convergence Norm $=0.15391 E+08$ Previous Norm $=0.15391 E+08$

$M$ Convergence Norm $=0.16021 \mathrm{E}-11$ Previous Norm $=0.16021 \mathrm{E}-11$

Element Formation Element $=640 \mathrm{Cum}$. Iter. $=29 \mathrm{CP}=1822.010$

Time $=1.9300$ Load Step $=2$ Substep $=18$ Equilibrium Iteration $=2$.

F Convergence Norm $=0.15391 E+08$ Previous Norm $=0.15391 E+08$

$M$ Convergence Norm $=0.16021 \mathrm{E}-11$ Previous Norm $=0.16021 \mathrm{E}-11$

FORCE CONVERGENCE VALUE $=0.4659 \mathrm{E}-10$ CRITERION $=1.911<<<$ CONVERGED

MOMENT CONVERGENCE VALUE $=0.1690 \mathrm{E}-11$ CRITERION $=8.969<<<$ CONVERGED

$>>>$ SOLUTION CONVERGED AFTER EOUILIBRIUM ITERATION 1

Element Output Element $=170 \mathrm{Cum}$. Iter, $=28 \mathrm{CP}=1832.490$

Time $=1.9300$ Load Step $=2$ Substep $=18$ Equilibrium Iteration $=1$.

F Convergence Norm $=0.46592 \mathrm{E}-10$ Previous Norm $=0.15391 \mathrm{E}+08$

$M$ Convergence Norm $=0.16901 \mathrm{E}-11$ Previous Norm $=0.16021 \mathrm{E}-11$

Element Output Element $=840$ Cum. Iter. $=28 \mathrm{CP}=1843.200$

Time $=1.9300$ Load Step $=2$ Substep $=18$ Equilibrium Iteration $=1$.

F Convergence Norm $=0.46592 \mathrm{E}-10$ Previous Norm $=0.15391 \mathrm{E}+08$

$M$ Convergence Norm $=0.16901 E-11$ Previous Norm $=0.16021 \mathrm{E}-11$

*** LOAD STEP . 2 SUBSTEP 18 COMPLETED. CUM ITER =

*** TIME $=1.93000 \quad$ TIME INC $=0.992585 \mathrm{E}-03$ 


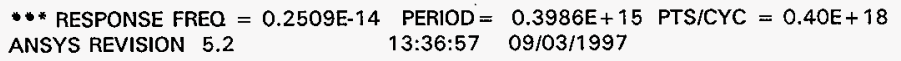

\section{PRINTOUT RESUMED BY /GOP}

Load step file number 3 . Begin solution ...

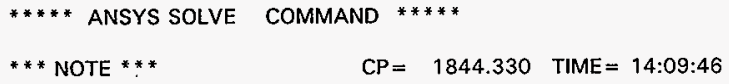

Results printout suppressed for interactive execute.

** NOTE *. $\quad \mathrm{CP}=1844.330$ TIME $=14: 09: 46$

Nonlinear analysis, NROPT set to 2 (modified Newton-Raphson solution procedure) for ALL. DOFs.

\section{LOAD STEP OPTIONS}

LOAD STEP NUMBER. . . . . . . . . 3

TIME AT END OF THE LOAD STEP. . . . . . . 1.9800

NUMBER OF SUBSTEPS. . . . . . . . . 500

MAXIMUM NUMBER OF EQUILIBRIUM ITERATIONS. . . 40

STEP CHANGE BOUNDARY CONDITIONS ....... YES

TRANSIENT (INERTIA) EFFECTS

STRUCTURAL DOFS. . . . . . . . O ON

TRANSIENT INTEGRATION PARAMETERS

ALPHA. . . . . . . . . . 0.25251

DELTA. . . . . . . . . 0.50500

TERMINATE ANALYSIS IF NOT CONVERGED . . . . . YES (EXIT)

CONVERGENCE CONTROLS. .......... USE DEFAULTS

INERTIA LOADS $X$ $Y$ $Z$

ACEL $\ldots \ldots \ldots \ldots 0.00000 E+00 \quad 0.00000 E+00 \quad 386.40$

COPY INTEGRATION POINT VALUES TO NODE . . . . Y YES, FOR ELEMENTS WITH

ACTIVE MAT. NONLINEARITIES

PRINT OUTPUT CONTROLS . . . . . . . . . .NO PRINTOUT

DATABASE OUTPUT CONTROLS

ITEM FREOUENCY COMPONENT

ALL 5

ALL 3

Element Formation Element $=220 \mathrm{Cum}$. Iter. $=29 \mathrm{CP}=1851.340$

Time $=1.9301$ Load Step $=3$ Substep $=1$ Equilibrium Iteration $=1$.

$F$ Convergence Norm $=0.46592 \mathrm{E}-10$ Previous Norm $=0.15391 \mathrm{E}+08$

$M$ Convergence Norm $=0.16901 \mathrm{E}-11$ Previous Norm $=0.16021 \mathrm{E}-11$

Element Formation Element $=650 \mathrm{Cum}$. Iter. $=29 \mathrm{CP}=1861.960$

Time $=1.9301$ Load Step $=3$ Substep $=1$ Equilibrium Iteration $=1$.

$F$ Convergence Norm $=0.46592 \mathrm{E}-10$ Previous Norm $=0.15391 \mathrm{E}+08$

$M$ Convergence Norm $=0.16901 \mathrm{E}-11$ Previous Norm $=0.16021 \mathrm{E}-11$

FORCE CONVERGENCE VALUE $=0.1528 E+09$ CRITERION $=0.1528 \mathrm{E}+06$

MOMENT CONVERGENCE VALUE $=0.1690 \mathrm{E}-11$ CRITERION $=8.969$

Equation Solution Element $=330$ Cum. Iter. $=29 \mathrm{CP}=1872.710$ 
Time $=1.9301$ Load Step $=3$ Substep $=1$ Equilibrium Iteration $=1$.

$F$ Convergence Norm $=0.15281 \mathrm{E}+09$ Previous Norm $=0.15281 \mathrm{E}+09$

$M$ Convergence Norm $=0.16901 \mathrm{E}-11$ Previous Norm $=0.16901 \mathrm{E}-11$

EQUIL ITER 1 COMPLETED. NEW TRIANG MATRIX. MAX DOF INC $=-0.7455 E-01$

Element Formation Element $=10 \mathrm{Cum}$. Iter. $=30 \mathrm{CP}=1883.240$

Time $=1.9301$ Load Step $=3$ Substep $=1$ Equilibrium Iteration $=2$.

$F$ Convergence Norm $=0.15281 \mathrm{E}+09$ Previous Norm $=0.15281 \mathrm{E}+09$

$M$ Convergence Norm $=0.16901 \mathrm{E}-11$ Previous Norm $=0.16901 \mathrm{E}-11$

Element Formation Element $=430 \mathrm{Cum}$. Iter. $=30 \mathrm{CP}=1893.840$

Time $=1.9301$ Load Step $=3$ Substep $=1$ Equilibrium Iteration $=2$.

F Convergence Norm $=0.15281 \mathrm{E}+09$ Previous Norm $=0.15281 \mathrm{E}+09$

$M$ Convergence Norm $=0.16901 \mathrm{E}-11$ Previous Norm $=0.16901 \mathrm{E}-11$

Element Formation Element $=810 \mathrm{Cum}$. Iter. $=30 \mathrm{CP}=1904.450$

Time $=1.9301$ Load Step $=3$ Substep $=1$ Equilibrium Iteration $=2$.

$F$ Convergence Norm $=0.15281 \mathrm{E}+09$ Previous Norm $=0.15281 \mathrm{E}+09$

$M$ Convergence Norm $=0.16901 E-11$. Previous Norm $=0.16901 \mathrm{E}-11$

FORCE CONVERGENCE VALUE $=0.1559 E-07$ CRITERION $=1.911<<<$ CONVERGED

MOMENT CONVERGENCE VALUE $=0.1785 E-11$ CRITERION $=8.969 \quad<<<$ CONVERGED

$>>>$ SOLUTION CONVERGED AFTER EQUILIBRIUM ITERATION 1

ITERATION SUMMARY FOR INTERMEDIATE LOAD STEPS ARE DELETED.

** LOAD STEP 3 SUBSTEP 499 COMPLETED. CUM ITER = 661
* * TIME $=1.97990 \quad$ TIME INC $=0.100000 E-03$
* * RESPONSE FREO $=107.0 \quad$ PERIOD $=0.9348 E-02$ PTS $/ C Y C=93$.

Element Formation Element $=30 \mathrm{Cum}$. Iter $=662 \mathrm{CP}=44708.328$

Time $=1.9800$ Load Step $=3$ Substep $=500$ Equilibrium Iteration $=1$.

$F$ Convergence Norm $=0.49422 \mathrm{E}-07$ Previous Norm $=0.13839 \mathrm{E}+08$

$M$ Convergence Norm $=0.83391 \mathrm{E}-07$ Previous Norm $=0.89727 \mathrm{E}-07$

Element Formation Element $=430 \mathrm{Cum}$. Iter. $=662 \mathrm{CP}=44718.230$

Time $=1.9800$ Load Step $=3$ Substep $=500$ Equilibrium Iteration $=1$.

$F$ Convergence Norm $=0.49422 \mathrm{E}-07$ Previous Norm $=0.13839 \mathrm{E}+08$

$M$ Convergence Norm $=0.83391 \mathrm{E}-07$ Previous Norm $=0.89727 \mathrm{E}-07$

Element Formation Element $=810$ Cum. Iter. $=662 \mathrm{CP}=44728.539$

Time $=1.9800$ Load Step $=3$ Substep $=500$ Equilibrium Iteration $=1$.

$F$ Convergence Norm $=0.49422 \mathrm{E}-07$ Previous Norm $=0.13839 \mathrm{E}+08$

$\mathrm{M}$ Convergence Norm $=0.83391 \mathrm{E}-07$ Previous Norm $=0.89727 \mathrm{E}-07$

FORCE CONVERGENCE VALUE $=0.1355 E+08$ CRITERION $=0.1362 E+05$

MOMENT CONVERGENCE VALUE $=0.8339 \mathrm{E}-07$ CRITERION $=145.9$

Equation Solution Element $=520$ Cum. Iter. $=662 \mathrm{CP}=44738.852$

Time $=1.9800$ Load Step $=3$ Substep $=500$ Equilibrium Iteration $=1$.

$\mathrm{F}$ Convergence Norm $=0.13550 \mathrm{E}+08$ Previous Norm $=0.13550 \mathrm{E}+08$

$M$ Convergence Norm $=0.83391 \mathrm{E}-07$ Previous Norm $=0.83391 \mathrm{E}-07$

EQUIL ITER 1 COMPLETED. NEW TRIANG MATRIX. MAX DOF INC $=-0.1423 E-01$

Element Formation Element $=170 \mathrm{Cum}$. Iter. $=663 \mathrm{CP}=44749.590$

Time $=1.9800$ Load Step $=3$ Substep $=500$ Equilibrium Iteration $=2$. 
F Convergence Norm $=0.13550 E+08$ Previous Norm $=0.13550 E+08$

$M$ Convergence Norm $=0.83391 \mathrm{E}-07$ Previous Norm $=0.83391 \mathrm{E}-07$

Element Formation Element $=590 \mathrm{Cum}$. Iter. $=663 \mathrm{CP}=44760.129$

Time $=1.9800$ Load Step $=3$ Substep $=500$ Equilibrium Iteration $=2$.

F Convergence Norm $=0.13550 E+08$ Previous Norm $=0.13550 E+08$

$M$ Convergence Norm $=0.83391 \mathrm{E}-07$ Previous Norm $=0.83391 \mathrm{E}-07$

FORCE CONVERGENCE VALUE $=0.5108 \mathrm{E}-07$ CRITERION $=86.43$

MOMENT CONVERGENCE VALUE $=0.8061 \mathrm{E}-07$ CRITERION $=145.9$

$<<<$ CONVERGED.

$>>>$ SOLUTION CONVERGED AFTER EOUILIBRIUM ITERATION 1

Element Output Element $=40$ Cum. Iter. $=662 \mathrm{CP}=44770.059$

Time $=1.9800$ Load Step $=3$ Substep $=500$ Equilibrium Iteration $=1$.

$\mathrm{F}$ Convergence Norm $=0.51077 \mathrm{E}-07$ Previous Norm $=0.13550 \mathrm{E}+08$

M Convergence Norm $=0.80606 \mathrm{E}-07$ Previous Norm $=0.83391 \mathrm{E}-07$

Element Output Element $=710 \mathrm{Cum}$. Iter. $=662 \mathrm{CP}=44780.512$

Time $=1.9800$ Load Step $=3$ Substep $=500$ Equilibrium Iteration $=1$.

$F$ Convergence Norm $=0.51077 \mathrm{E}-07$ Previous Norm $=0.13550 \mathrm{E}+08$

$M$ Convergence Norm $=0.80606 \mathrm{E}-07$ Previous Norm $=0.83391 \mathrm{E}-07$

** *OAD STEP 3 SUBSTEP 500 COMPLETED. CUM ITER = 662

$* *$ * TIME $=1.98000 \quad$ TIME INC $=0.100000 \mathrm{E}-03$

* * RESPONSE FREO $=106.9$ PERIOD $=0.9352 \mathrm{E}-02$ PTS $/ \mathrm{CYC}=94$.

SOLU_LS4:

FINISH SOLUTION PROCESSING

$\cdots \cdots *$ ROUTINE COMPLETED **** CP $=44783.039$

** * NOTE * * CP= 44783.051 TIME $=03: 01: 17$

A total of 42 warnings and errors written to file.err.

BEGIN:

PURGE ALL SOLUTION AND POST DATA

SAVE ALL MODEL DATA

*** NOTE *** CP $=44783.551$ TIME $=03: 01: 18$

NEW BACKUP FILE NAME $=$ file.dbb.

ALL CURRENT ANSYS DATA WRITTEN TO FILE NAME $=$ file.db FOR POSSIBLE RESUME FROM THIS POINT

NUMBER OF WARNING MESSAGES ENCOUNTERED $=\quad 42$ NUMBER OF ERROR MESSAGES ENCOUNTERED $=0$

DATA INPUT WRITTEN ON file.log 


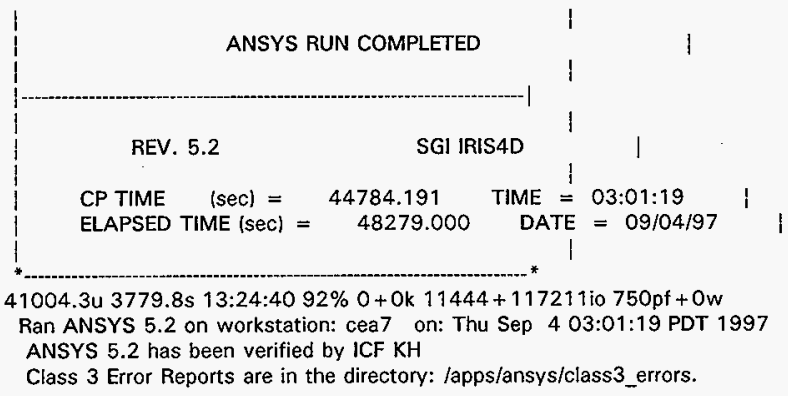


HNF-SD-TWR-CN-002

Rev. 0

Appendix B

POST26 SUMMARY OF VARIABLE EXTREME VALUES

VARI TYPE IDENTIFIERS NAME MINIMUM AT TIME MAXIMUM AT TIME

\begin{abstract}
2 NSOL $104 \mathrm{UZ}$
3 NSOL 20132 UZ

4 NSOL $23041 \mathrm{UZ}$

5 RFOR $11315 \mathrm{FZ}$

6 RFOR $11316 \mathrm{FZ}$

7 RFOR $11317 \mathrm{FZ}$

8 RFOR $11318 \mathrm{FZ}$

9 RFOR $11319 \mathrm{FZ}$

10 RFOR $11320 \mathrm{FZ}$

11 RFOR $11321 \mathrm{FZ}$

12 RFOR $11322 \mathrm{FZ}$

13 RFOR $11323 \mathrm{FZ}$

14 RFOR $11324 \mathrm{FZ}$

15 RFOR $11325 \mathrm{FZ}$

16 RFOR $11326 \mathrm{FZ}$

17 RFOR $11327 \mathrm{FZ}$

18 RFOR $11328 \mathrm{FZ}$

19 RFOR $11329 \mathrm{FZ}$

20 RFOR $11465 \mathrm{FZ}$

21 RFOR $11479 \mathrm{FZ}$

22 RFOR $11555 \mathrm{FZ}$

23 RFOR $11569 \mathrm{FZ}$

24 RFOR $11618 \mathrm{FZ}$

25 RFOR $11628 \mathrm{FZ}$
\end{abstract}

$\begin{array}{llllll}\text { uz104 } & -0.5615 & 1.948 & -0.6351 E-02 & 1.926 \\ \text { uz20132 } & -17.83 & 1.970 & -0.4671 E-02 & 1.926 \\ \text { uz23041 } & -738.6 & 1.970 & -716.1 & 1.926 \\ f z 11315 & 0.0000 E+00 & 1.933 & 9805 & 1.959 \\ f z 11316 & 0.0000 E+00 & 1.934 & 0.1099 E+05 & 1.959 \\ f z 11317 & 0.0000 E+00 & 1.942 & 9208 . & 1.961 \\ f z 11318 & 0.0000 E+00 & 1.953 & 0.1528 E+05 & 1.949 \\ f z 11319 & 0.0000 E+00 & 1.953 & 7275 . & 1.949 \\ f z 11320 & 0.0000 E+00 & 1.953 & 5148 . & 1.962 \\ f z 11321 & 0.0000 E+00 & 1.954 & 5089 . & 1.968 \\ f z 11322 & 0.0000 E+00 & 1.955 & 8625 . & 1.960 \\ f z 11323 & 0.0000 E+00 & 1.957 & 0.1027 E+05 & 1.937 \\ f z 11324 & 74.34 & 1.932 & 8114 . & 1.937 \\ f z 11325 & 0.0000 E+00 & 1.965 & 5559 . & 1.961 \\ f z 11326 & 71.01 & 1.932 & 7077 . & 1.948 \\ f z 11327 & 105.6 & 1.953 & 0.1268 E+05 & 1.948 \\ f z 11328 & 0.0000 E+00 & 1.953 & 0.2444 E+05 & 1.944 \\ f z 11329 & 0.0000 E+00 & 1.926 & 0.0000 E+00 & 1.926 \\ f z 11465 & 0.0000 E+00 & 1.942 & 0.3413 E+05 & 1.948 \\ f z 11479 & 0.0000 E+00 & 1.926 & 0.0000 E+00 & 1.926 \\ f z 11555 & 0.0000 E+00 & 1.934 & 0.2388 E+05 & 1.947 \\ f z 11569 & 0.0000 E+00 & 1.926 & 0.0000 E+00 & 1.926 \\ f z 111618 & 0.0000 E+00 & 1.934 & 0.2168 E+05 & 1.946 \\ f z 11628 & 0.0000 E+00 & 1.934 & 0.4765 E+05 & 1.967\end{array}$


POST26 SUMMARY OF VARIABLE EXTREME VALUES

VARI TYPE IDENTIFIERS NAME MINIMUM AT TIME MAXIMUM AT TIME

\begin{tabular}{|c|c|c|c|c|c|c|c|c|}
\hline ESOL & $814 \mathrm{~F}$ & $\mathbf{Z}$ & $\{z 132$ & -2350 & 1.933 & 29.31 & \multicolumn{2}{|c|}{1.930} \\
\hline $\mathrm{OL}$ & $814 \mathrm{~F}$ & Z & $\mathrm{fz} 20132$ & -29.31 & 1.930 & 2350. & \multicolumn{2}{|c|}{1.933} \\
\hline $4 \mathrm{ESOL}$ & $133 \mathrm{~F}$ & $\mathrm{x}$ & $f \times 372$ & -3532 & 1.961 & 9666. & \multicolumn{2}{|c|}{1.943} \\
\hline $5 \mathrm{ESOL}$ & $133 \mathrm{~F}$ & $\mathrm{Y}$ & fу 372 & -1165. & 1.956 & 6796. & \multicolumn{2}{|c|}{1.944} \\
\hline $6 \mathrm{ESOL}$ & $133 \mathbf{F}$ & $\mathbf{Z}$ & $f z 372$ & -5058 & 1.938 & 44.95 & \multicolumn{2}{|c|}{1.931} \\
\hline $7 \mathrm{ESOL}$ & $136 \mathrm{~F}$ & $\mathrm{x}$ & $f \times 432$ & 614.1 & 1.932 & \multicolumn{3}{|c|}{$0.2828 \mathrm{E}+05 \quad 1.945$} \\
\hline $8 \mathrm{ESOL}$ & $136 \mathrm{~F}$ & $\mathrm{Y}$ & fy 432 & -3524 & 1.945 & 1302. & \multirow{2}{*}{\multicolumn{2}{|c|}{$\begin{array}{l}1.961 \\
1.964\end{array}$}} \\
\hline 9 ESOL & $136 \mathrm{~F}$ & Z & fz432 & -6744 & 1.937 & 44.65 & & \\
\hline 10 ESOL & $199 \mathrm{~F}$ & $\mathrm{x}$ & $f \times 456$ & \multirow{2}{*}{\multicolumn{2}{|c|}{$-0.1071 E+051.942$}} & \multirow{2}{*}{\multicolumn{2}{|c|}{2583.}} & 1.956 \\
\hline 11 ESOL & $199 \mathrm{~F}$ & $Y$ & fy 456 & & & & & 1.958 \\
\hline $12 \mathrm{ESOL}$ & $199 \mathrm{~F}$ & $z$ & fz456 & -6172 & 1.959 & 1188. & \multicolumn{2}{|c|}{1.942} \\
\hline 13 ESOL & $205 \mathrm{~F}$ & $\mathrm{x}$ & $f \times 460$ & $-0.2172 \mathrm{E}$ & +051.945 & \multicolumn{2}{|c|}{$5 \quad 163.1$} & 1.957 \\
\hline 14 ESOL & $205 \mathrm{~F}$ & $\mathbf{Y}$ & fy 460 & -598.6 & 1.955 & $0.1434 E$ & +05 & 1.945 \\
\hline 15 ESOL & $205 \mathrm{~F}$ & $\mathbf{z}$ & $\mathrm{fz} 460$ & -5718. & 1.937 & 1037. & \multicolumn{2}{|c|}{1.941} \\
\hline $16 \mathrm{E}$ & $112 \mathrm{~F}$ & $\mathrm{x}$ & $f \times 364$ & -4630 . & 1.955 & \multirow{2}{*}{$\begin{array}{l}9281 . \\
7 \quad 3072\end{array}$} & \multicolumn{2}{|c|}{1.947} \\
\hline $17 \mathrm{ESOL}$ & $112 \mathrm{~F}$ & $\mathbf{Y}$ & fy 364 & $-0.1073 \mathrm{E}$ & $+05 \quad 1.947$ & & & 1.955 \\
\hline $18 \mathrm{ESOL}$ & $112 \mathrm{~F}$ & $z$ & fz364 & -5230 & 1.958 & \multirow{2}{*}{$\begin{array}{l}859.1 \\
0.1275 \mathrm{E}\end{array}$} & \multicolumn{2}{|c|}{1.961} \\
\hline $19 \mathrm{ESOL}$ & $115 \mathrm{~F}$ & $\mathrm{x}$ & $f \times 4$ & -4622 & 55 & & +05 & 1.947 \\
\hline 20 ESOL & $115 \mathrm{~F}$ & $\mathrm{r}$ & fy 424 & -2774 & 1.955 & 6732. & \multicolumn{2}{|c|}{1.947} \\
\hline $21 \mathrm{ESOL}$ & $115 \mathrm{~F}$ & $z$ & fz424 & -5106. & 1.959 & 2293. & \multicolumn{2}{|c|}{1.949} \\
\hline 22 ESOL & $180 \mathrm{~F}$ & $x$ & $f \times 336$ & -1929. & 1.948 & 2851. & \multicolumn{2}{|c|}{1.955} \\
\hline $23 \mathrm{ESOL}$ & $180 \mathrm{~F}$ & $\mathrm{Y}$ & fy 336 & -6309. & 1.955 & 5756. & \multicolumn{2}{|c|}{1.948} \\
\hline $24 \mathrm{ESOL}$ & $180 \mathrm{~F}$ & $\mathbf{Z}$ & fz336 & -6471 & 1.937 & \multirow{2}{*}{$\begin{array}{l}129.5 \\
4175\end{array}$} & \multicolumn{2}{|c|}{1.955} \\
\hline & & $x$ & & 4. & 55 & & 1.92 & \\
\hline $26 \mathrm{ESOL}$ & $186 \mathrm{~F}$ & $\mathrm{Y}$ & fy 340 & -2377 & 1.955 & 5276. & 1.94 & \\
\hline $27 \mathrm{ESOL}$ & $186 \mathrm{~F}$ & Z & fz340 & -5556. & 1.938 & 700.6 & 1.94 & \\
\hline $28 \mathrm{NSOL}$ & $100 \mathrm{UZ}$ & & uz100 & -0.5161 & 1.949 & $-0.5826 \mathrm{E}$ & $=02$ & 1.926 \\
\hline $29 \mathrm{NSOL}$ & $101 \mathrm{UZ}$ & & uz101 & -0.5287 & 1.948 & $-0.6016 \mathrm{E}$ & $=02$ & 1.926 \\
\hline $30 \mathrm{NSOL}$ & $103 \mathrm{UZ}$ & & uz103 & -0.5607 & 1.948 & $-0.6298 \mathrm{E}$ & $=02$ & 1.926 \\
\hline 31 NSOL & $104 \mathrm{UZ}$ & & uz104 & -0.5615 & 1.948 & $-0.6351 E$ & $=-02$ & 1.926 \\
\hline $32 \mathrm{NSOL}$ & $102 \mathrm{UZ}$ & & uz102 & -0.5471 & 1.948 & $-0.6180 \mathrm{E}$ & $=02$ & 1.926 \\
\hline $33 \mathrm{NSOL}$ & $105 \mathrm{UZ}$ & & uz105 & -0.5458 & 1.948 & $-0.6320 \mathrm{E}$ & $=02$ & 1.926 \\
\hline 34 NSOL & $130 \mathrm{UZ}$ & & uz130 & -0.5115 & 1.949 & $-0.5432 E$ & $=-02$ & 1.926 \\
\hline $35 \mathrm{NSOL}$ & $131 \mathrm{UZ}$ & & Uz131 & -0.5123 & 1.949 & $-0.5630 \mathrm{E}$ & $=-02$ & 1.926 \\
\hline
\end{tabular}


HNF-SD-TWR-CN-002

Rev. 0

\section{APPENDIX C}

STRUCTUAL CALCULATIONS

c-1 
Fluor Daniel Northwest

HNF-SD-TWR-CN-002

Title : Mixer and Transfer pump drop analysis. Proiect W-211

Rev. 0 Appendix - C

Designed by:S. Kanilial Se Checked by N.D. Ha Uhe Page C-2

Date $9 \cdot 16-97$

Date

$9 / 16 / 97$

Design qualification of Pump Pit concrete wall for Pump drop impact loading:

Max. reaction from ANSYS analysis $=71.9 \mathrm{kip}$, Design load for concrete wall is considered as 72 kips.

Define Units for MathCad Program :

kip : $=1000-1 b f$

ton : $=2 \cdot$ kip

$\mathrm{ksi}:=\frac{\mathrm{kip}}{\mathrm{in}^{2}}$

Design Base Plate for 72 Kip loading :

$\mathrm{W}:=72 \cdot \mathrm{kip}$

Section Properties for $W 12 \times 40$
$\mathrm{A}:=11.8 \cdot \mathrm{in}^{2}$
bf $:=8.005 \cdot$ in
dAf $:=2.90 \cdot$ in $^{-1}$
$\mathrm{k}:=1.25 \cdot \mathrm{in}$
$d:=11.94 \cdot$ in
tf $:=0.515 \cdot$ in
$\mathrm{Sx}:=51.9 \cdot \mathrm{in}^{3}$
Sy $:=11.0 \cdot \mathrm{in}^{3}$
tw $:=0.295 \cdot \mathrm{in}$
$\mathrm{rT}:=2.14 \cdot$ in
$\mathrm{rx}:=5.13 \cdot$ in
ry $:=1.93 \cdot$ in

Check load at top of the pit wall (beam end)

Reference to AISC Manual of Steel Construction, Allowable Stress Design, 9th. Edition. (page 2-31)

Compressive Strength of Concrete $=4000$ psi

Rebar allowable stress $=60,000$ psi.

(Refer Dwg. H - 2 - 76462)

fc $:=4000 \cdot \mathrm{psi} \quad \phi \mathrm{b}:=.85$

Allowable Bearing Pressure of Concrete Fp $\mathrm{Fp}:=\phi b \cdot 0.7 \cdot \mathrm{fc} \quad \mathrm{Fp}=2.38 \cdot 10^{3}$ psi

Length of bearing on concrete wall required $=\mathrm{Np}$ $\mathrm{Np}:=\frac{\mathrm{W}}{\mathrm{Fp} \cdot \mathrm{bf}} \quad \mathrm{Np}=3.779 \cdot \mathrm{in}$

Length of bearing actual $=5.75^{\prime \prime}>3.78^{\prime \prime}$

O. K

Yield strength of steel $=\mathrm{Fy}$

Fy $:=36 \cdot \mathrm{ksi}$

(Refer Dwg. H - 2-76462)

Check web yielding - (Refer ASD spec. section K1.3)

$R / t w(N+2.5 k)<.66 F y$ 
Title :Mixer and Transfer pump drop analysis, Project W-211

Designed by: S. Kanilial S飞

Date

$9[10197$

Checked by N.D. Ha whe

Page C-3

Date $9 / 16 / 94$

Find length of bearing required $=\mathrm{Ny}$

$\mathrm{Ny}:=\frac{\mathrm{W}}{.66 \cdot \mathrm{Fy} \cdot \mathrm{tw}}-2.5 \cdot \mathrm{k} \quad \mathrm{Ny}=7.147 \cdot \mathrm{in}$

Check web crippling : (Ref. ASD Spec. Section K1.4)

$$
W=34 \cdot t w^{2} \cdot\left[1+3 \cdot\left(\frac{N}{d}\right) \cdot\left(\frac{t w}{t f}\right)^{1.5}\right] \cdot \sqrt{F y \cdot \frac{t f}{t w}}
$$

Length of bearing required : Nc

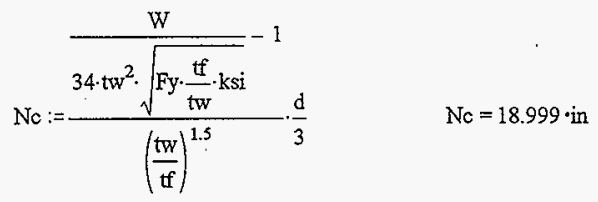

The width of wall at top is $53 / 4 "$. The flange width is $8 "$. Try a base plate $8 " \times 53 / 4 "$ (same as flange width)

set $\quad \mathrm{N}:=5.75 \cdot$ in

Bearing Pressure $=\mathrm{pb}$

$$
\mathrm{pb}:=\frac{\mathrm{W}}{\mathrm{bf}-\mathrm{N}} \quad \mathrm{pb}=1.564 \cdot \mathrm{ksi}
$$

Bending stress at face of web

$$
\delta:=\frac{\frac{1}{2} \cdot p b \cdot N \cdot\left(\frac{b f-t w}{2}\right)^{2}}{\left(\frac{1}{6}\right) \cdot N \cdot w^{2}} \quad \delta=801.363 \cdot \mathrm{ksi}
$$

Bending stress is too high. 


\section{Fluor Daniel Northwest}

HNF-SD-TWR-CN-002

Title :Mixer and Transfer pump drop analysis. Project W-211

Designed by: S. Kanilial SK

Design
Rev. 0
Appendix-C Checked by

Date

Page $\mathrm{C}-4$

$9 / 16 / 67$

Set bearing stress $=0.75 \times F y$, then

$$
\mathrm{pb}:=\frac{0.75 \cdot \mathrm{Fy} \cdot \frac{1}{6} \cdot \mathrm{tw}^{2}}{\frac{1}{2} \cdot\left(\frac{\mathrm{bf}-\mathrm{tw}}{2}\right)^{2}} \quad \mathrm{pb}=0.053 \cdot \mathrm{ksi}
$$

Find length of bearing $\mathrm{Nd}$

$$
\mathrm{Nd}:=\frac{\mathrm{W}}{\mathrm{pb} \cdot \mathrm{bf}} \quad \mathrm{Nd}=170.661 \cdot \text { in }
$$

Too long.

Add 1/4" stiffner plate on both sides of the web:

Stiffner plate size $=10.91^{\prime \prime} \times 3.855^{\prime \prime} \times 1 / 4^{\prime \prime}$

Check width-thickness ratio:

$$
\begin{aligned}
& \text { bs }:=3.855 \cdot \text { in } \quad \text { ts }:=0.25 \cdot \mathrm{in} \\
& \frac{\mathrm{bs}}{\mathrm{ts}}=15.42 \quad<15.8=95 / \sqrt{\mathrm{Fy}} \quad \begin{array}{l}
\text { AlSC Table B } 5.1 \\
\text { O. K. }
\end{array}
\end{aligned}
$$

Effective compression area :

Effective web length $=12 \times$ tw

$$
\text { webl }:=12 \cdot \text { tw } \quad \text { webl }=3.54 \cdot \text { in }
$$

Effective compression area $=$ Acom

Acom $:=(2 \cdot b s \cdot t s)+$ webl.tw

Compresside Stress $=\delta a$

$$
\text { Acom }=2.972 \cdot \text { in }^{2}
$$

$$
\delta a:=\frac{W}{A c o m} \quad \delta a=24.228 \cdot k s i
$$

The compressive stress is high. Use 2 stiffners 4" apart.

$$
\begin{array}{lr}
\text { Arev }:=2 \cdot(2 \cdot \mathrm{bs} \cdot \mathrm{ts})+\text { webl.tw } & \text { Arev }=4.899 \cdot \mathrm{in}^{2} \\
\delta \text { arev }:=\frac{\mathrm{W}}{\text { Arev }} & \delta \text { arev }=14.696 \cdot \mathrm{ksi}
\end{array}
$$


Fluor Daniel Northwest

HNF-SD-TWR-CN-002

Rev. 0

Appendix-C

Title: Mixer and Transfer pump drop analysis, Project $W-21$

Designed by:S. Kanilial $8<-$ Checked by N.D.Ha Uhe Page C-5

Date $\quad$ al16ia

Date

q) 16142

Find $\mathrm{K} 1 / \mathrm{r}$ for the stiffner section :

$$
\begin{aligned}
& \mathrm{Ixx}:=2 \cdot\left(\frac{1}{12} \cdot \mathrm{ts} \cdot 2 \cdot \mathrm{bs}^{3}\right) \quad \mathrm{Ixx}=4.774 \cdot \mathrm{in}^{4} \\
& \mathrm{r}:=\sqrt{\frac{\mathrm{Ixx}}{\text { Arev }}} \quad \mathrm{r}=0.987 \cdot \mathrm{in} \\
& \mathrm{K}:=1 \quad \frac{\mathrm{K} \cdot \mathrm{d}}{\mathrm{r}}=12.096 \quad \mathrm{Es}:=29 \cdot 10^{3} \cdot \mathrm{ksi} \\
& \mathrm{Cc}:=\sqrt{\frac{2 \cdot \pi^{2} \cdot \mathrm{Es}}{\mathrm{Fy}}} \quad \mathrm{Cc}=126.099
\end{aligned}
$$

$$
\begin{aligned}
& \underline{K} \cdot \mathrm{d} \\
& \begin{array}{ll}
\frac{\mathrm{r}}{\mathrm{Cc}}=0.096 \quad \mathrm{Ca}:=.586 \quad \mathrm{Fa}:=\mathrm{Ca} \cdot \mathrm{Fy} \\
& \mathrm{Fa}=21.096 \cdot \mathrm{ksi} \quad \mathrm{Fa}=\text { Allowable compressive stress }
\end{array}
\end{aligned}
$$

Allowable Compressive stress $=21.096 \mathrm{ksi}>14.7 \mathrm{ksi} \mathrm{O} . \mathrm{K}$

USE $2-1 / 4^{\prime \prime}$ stiffner to the beam with a bearing plate $8^{\prime \prime} \times 53 / 4^{\prime \prime}$. Provide $3 / 16^{\prime \prime}$ all round weld

Check Bolts attaching 2" thick cover plate with beam flange.

Max. reaction at node 534 at the corner of the plate.

This bolt will see shear $=36.852$ kips and tension $=7.215$ kips.

Provide 2 - 1" dia. A 490 bolts. This ia bearing type connection and the bolt is in single shear.

Allowable shear stress ( Threads are not included in the shear plane) $=28 \mathrm{ksi}$ (Refer Table J3.2 AISC 9th edition ).

Since the bolts carry tension the shear stress allowable is reduced as per Table $\mathrm{J} 3.3$, AlsC 9th. edition. Allowable Tension stress $=\mathrm{Ft}$

Place $2-1^{\text {t dia. }}$. bolt at the corner. Area of bolt $=A B$

$$
\mathrm{Ab}:=.7854 \cdot \mathrm{in}^{2} \quad \mathrm{~V}:=36852 \cdot 1 \mathrm{~b} \quad \mathrm{~T}:=7215 \cdot \mathrm{lb}
$$




\section{Fluor Daniel Northwest}

HNF-SD-TWR-CN-002

Rev. 0

Appendix - C

Title : Mixer and Transfer pump drop analysis, Project W-211

$\begin{array}{lll}\text { Designed by : S. Kanilal SE } & \text { Checked by N.D. Ha A Ke Page C-6 } \\ \text { Date } 9116197 & \text { Date } 9 / 16 / 97\end{array}$

fv $:=\frac{\frac{V}{2}}{(A b)}$

$\mathrm{fv}=2.346 \cdot 10^{4} \cdot \frac{\mathrm{lb}}{\mathrm{in}^{2}}$

Sear stress per bolt $=23.46 \mathrm{kip} / \mathrm{sq} . \mathrm{in}$

Ft $:=\sqrt{54^{2}-3.75 \cdot 23.46^{2}} \quad F t=29.191$

Or Tension Allowable Stress $=29.19 \mathrm{ksi}$ Increase $33 \%$ for occasional loads.

Ftallow $=1.33 \times 29.19=38.83 \mathrm{ksi}$

$\mathrm{ft}:=\frac{\frac{\mathrm{T}}{2}}{\mathrm{Ab}}$

$\mathrm{ft}=4.593 \cdot 10^{3} \cdot \frac{\mathrm{lb}}{\mathrm{in}^{2}}$

$\mathrm{ft}=$ Actual tension stress $(=4.593 \mathrm{ksi})<$ Ftallow $(=38.83 \mathrm{ksi}$ ) O. K.

Shear stress on this two boits : $23.46 \mathrm{kip} / \mathrm{sq}$.in

Alowable shear stress $28 \mathrm{ksi} \times 1.33=37.24 \mathrm{ksi} \gg 23.46 \mathrm{ksi}$. Hence the shear stress in two corner bolts are $\mathrm{O} . \mathrm{K}$

Check bolt at node 514 (Next critical load)

$\mathrm{V} 514:=20096 \cdot 1 \mathrm{~b} \quad T 514:=11330 \cdot 1 \mathrm{~b}$

fv514 : $=\frac{\mathrm{V} 514}{\mathrm{Ab}} \quad$ fv514 $=2.559 \cdot 10^{4} \cdot \frac{\mathrm{lb}}{\mathrm{in}^{2}}$

Or shear stress in this bolt $=25.59 \mathrm{ksi}$

Allowable shear stress $=28 \mathrm{ksi} \times 1.33=$

Tension Allowable (T514)

37.24 ksi (Refer table J3.2 AlSC 9th.

Edition)

Tens514 $:=\sqrt{54^{2}-3.75 \cdot 25.59^{2}} \quad$ Tens514 $=21.455 \quad$ Tension allowable $=21.455 \mathrm{ksi}$.

Multiplying the allowable by 1.33 for accident condition, Tension allowable $=1.33 \times 21.455=$ $28.54 \mathrm{ksi}$

$$
\mathrm{t} 514:=\frac{\mathrm{T} 514}{\mathrm{Ab}} \quad \mathrm{t} 514=1.443 \cdot 10^{4} \cdot \frac{\mathrm{lb}}{\mathrm{in}^{2}} \quad<28.54 \mathrm{ksi} \text { ( Tension Allowable) }
$$

1 " dia. bolt is $O$. K. For other bolts the loads are comparitively smaller, but use 1 " dia. bolt (conservative.) 


\section{Fluor Daniel Northwest}

HNF-SD-TWR-CN-002

Title: Mixer and Transfer pump drop analysis, Project W-211

Rev. 0

Appendix - C

Designed by:S. Kanilal $S_{K}$ Checked by N.D.Ha Ifle Page C-7 .

Date 9licis 7

Date $9 / 16 / 97$

\section{Check 12 wf 40 on the west wall.}

Maximum reaction $=28.7 \mathrm{kip} / \mathrm{ft}$.

Consider $1 \mathrm{ft}$. of the section.

Load on the effective flange width on one side of flange:

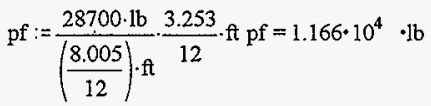

where $\mathrm{pf}=\mathrm{load} / \mathrm{ft}$ on one side of the flange.

Moment of this load at the root of the flange (at the point where flange starts curving to web)

$\mathrm{mf}:=\mathrm{pf} \cdot \frac{3.253}{2} \cdot$ in

$\mathrm{mf}=1.897 \cdot 10^{4} \cdot 1 \mathrm{~b} \cdot \mathrm{in}$

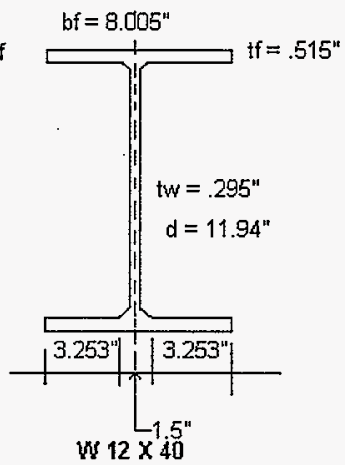

Section Modulus for 12 "length of the section

sf $:=\frac{1}{6} \cdot 12 \cdot \mathrm{in} \cdot(.515 \cdot \mathrm{in})^{2} \quad$ sf $=0.53 \cdot \mathrm{in}^{3}$

$\delta f:=\frac{\mathrm{mf}}{\mathrm{sf}} \quad \delta \mathrm{f}=3.576 \cdot 10^{4} \cdot \frac{\mathrm{lb}}{\mathrm{in}^{2}}$

Allowable bending stress $=.75 \times \mathrm{Fy}(=36 \mathrm{ksi})=27 \mathrm{ksi}$ AlSC 9th edition.

increase Allowable stress by 1.33 for dynamic loading.

Design allowable stress $=1.33 \times 27=35.91 \mathrm{ksi}>35.76 \mathrm{ksi}$

No stiffner required. The beam flanges are $0 . K$.

Check web compression :

$$
\begin{array}{ll}
\text { Aw }:=12 \cdot \mathrm{in} \cdot 295 \cdot \mathrm{in} & \mathrm{Aw}=3.54 \cdot \mathrm{in}^{2} \\
\delta \mathrm{fc}:=\frac{28700 \cdot \mathrm{lb}}{\mathrm{Aw}} & \delta \mathrm{fc}=8.107 \cdot 10^{3} \cdot \frac{\mathrm{lb}}{\mathrm{in}^{2}}
\end{array}
$$

Compressive stress in the web $=8.1 \mathrm{ksi}$ this is small the web is $O . K$ 
Fluor Daniel Northwest

HNF-SD-TWR-CN-002

Rev. 0

Appendix - C

Title: Mixer and Transfer pump drop analysis, Project W-211

Designed by:S. Kaniilal Se Checked by N.D. Ha kf. Page C-8

Date

9|16197?

Date

$9 / 16 / 57$

\section{Check welds at the connection of 12 wf 40 and 12 wf 40 :}

Weld forces:

Forces in the beam is generated from the boit forces. Bolts are approx. $2^{\prime \prime}$ from the center of web, considering the max. forces at node \#534.

$$
\begin{aligned}
& \mathrm{fx}:=31220 \cdot \mathrm{lb} \quad \text { fy }:=19580 \cdot \mathrm{lb} \\
& \mathrm{fz}:=7215 \cdot \mathrm{lb}
\end{aligned}
$$

Weld Properties :

$A w:=4 \cdot 3 \cdot$ in $+2 \cdot 8.5 \cdot$ in $\quad A w=29 \cdot$ in

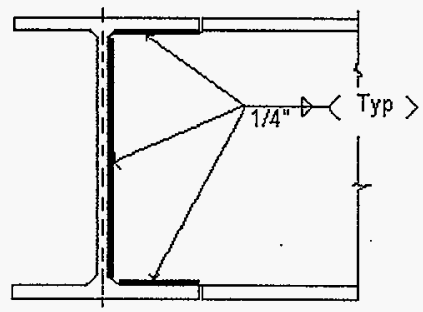

Find C.G. of the weld in $X$ direction :

$\mathrm{x}:=\frac{4 \cdot 3 \cdot \mathrm{in} \cdot 1.5 \cdot \mathrm{in}+2 \cdot 8.5 \cdot \mathrm{in} \cdot\left(4 \cdot \mathrm{in}-\frac{\mathrm{tw}}{2}\right)}{\mathrm{Aw}}$

$\mathrm{x}=2.879 \cdot$ in

CG from web face $=(4-.295 / 2)-2.879$

$$
=.9735^{\prime \prime}
$$

my $:=f z \cdot(2+.9735) \cdot i n+f x \cdot 4.25 \cdot$ in

$\mathrm{my}=1.541 \cdot 10^{5} \cdot \mathrm{lb} \cdot$ in

Torsional properties of the weld:

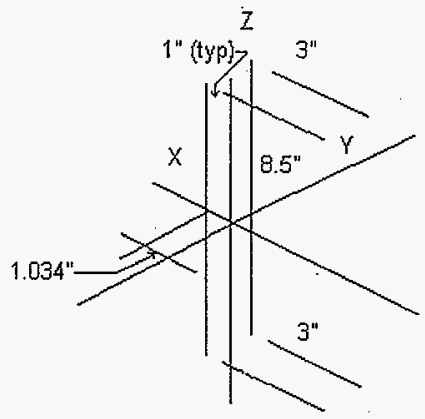

$b w:=3 \cdot$ in $\quad d w:=8.5 \cdot$ in

WELD CONFIGURATION

$$
J w:=2 \cdot \frac{(2 \cdot b w+d w)^{3}}{12}-b w^{2} \cdot \frac{(b w+d w)^{2}}{2 \cdot b w+d w} \quad J w=426.018 \cdot i^{3}
$$


Fluor Daniel Northwest

Title: Mixer and Transfer pump drop analysis, Project W-211

Designed by:S. Kanillal St2 Checked by N.D. Ha the page C-9

Date al16/57

Date

9116157

\section{Weld Stress :}

$$
\begin{array}{ll}
\text { fxw }:=\frac{f x}{A w}+\frac{m y \cdot x}{J w} & f x w=2.118 \cdot 10^{3} \cdot \frac{\mathrm{lb}}{\text { in }} \\
\text { fyw }:=\frac{f y}{A w} & f y w=675.172 \cdot \frac{\mathrm{lb}}{\text { in }} \\
\mathrm{fzw}:=\frac{\mathrm{fz}}{\mathrm{Aw}}+\mathrm{my} \cdot \frac{4.25}{\mathrm{Jw}} \cdot \mathrm{in} & \mathrm{fzw}=1.786 \cdot 10^{3} \cdot \frac{\mathrm{lb}}{\text { in }} \\
\mathrm{fr}:=\sqrt{\mathrm{fxw}^{2}+\mathrm{fy}^{2}+\mathrm{fzw}^{2}} & \mathrm{fr}=2.852 \cdot 10^{3} \cdot \frac{\mathrm{lb}}{\mathrm{in}}
\end{array}
$$

For $1 / 4$ " weld, weld allowable $=.707 \times 1 / 4 *$ in $X .3 \times 70000 \mathrm{psi}=3711 \mathrm{lb} / \mathrm{in}>2852 \mathrm{lb} / \mathrm{in}$. Weld is $0 . K$. 
Fluor Daniel Northwest

HNF-SD-TWR-CN-002

Rev. 0

Appendix-C

Tifle: Mixer and Transfer pump drop analysis, Project $W-211$

Designed bv:S. Kanillal Sc Checked by N.D. Ha the Page C-10

Date a.116) 7

Date

$916 / 47$

CHECK CONCRETE WALL :

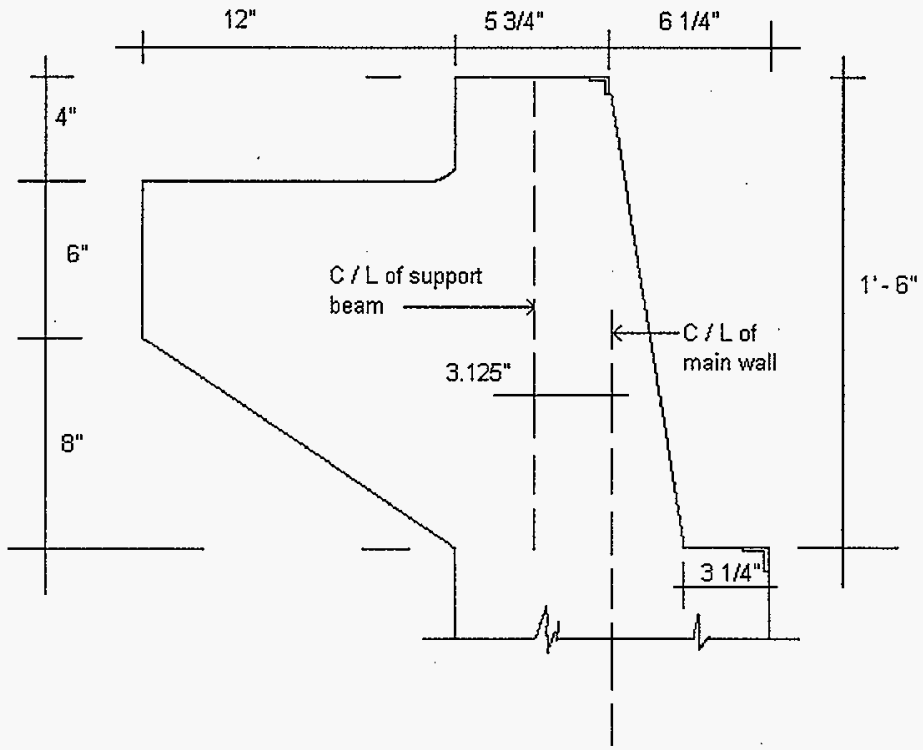

SECTION OF CONCRETE WALL AT TOP 


\section{Fluor Daniel Northwest}

HNF-SD-TWR-CN-002

Rev. 0

Appendix - C

Title : Mixer and Transfer pump drop analysis, Project W-211

Designed by: $S$. Kaniilal Sk

Date $9 / 16 / 57$ Checked by N.D. Ha lek

Date $9 / 16(q)$

Page $\mathrm{C}-11$

The concrete wall will behave as column of effective width of wall $W b=$ With
thickness of the wall. (Refer $A C l 318 / 318 R-89$ Section 14.2.4)

The concrete wall will behave as column of effective width of wall Wb $=$ Width of bearing $+4 X$
thickness of the wall.
(Refer $A C l ~ 318 / 318 R-89$ Section 14.2 .4 )
twall $:=12$-in
bwall $:=8 \cdot$ in $+4 \cdot$ twall
hwall $:=76.75 \cdot$ in $+6 \cdot$ in
Add 6 " for fixity
bwall $=56 \cdot$ in
hwall $=82.75 \cdot$ in
at base.
Assumed.

The support reaction is not at the centerline of the wall. As a result, the compressive load will create a moment about the center line of the wall.
Eccentricity $=$ ewall

$$
\text { ewall }:=\left(\frac{5.75}{2} \cdot \text { in }+6.25 \cdot \mathrm{in}\right)-\frac{\text { twall }}{2}, \begin{aligned}
& \text { Refer sketch of the wall } \\
& \text { at top. }
\end{aligned}
$$$$
\text { ewall }=3.125 \text { in }
$$

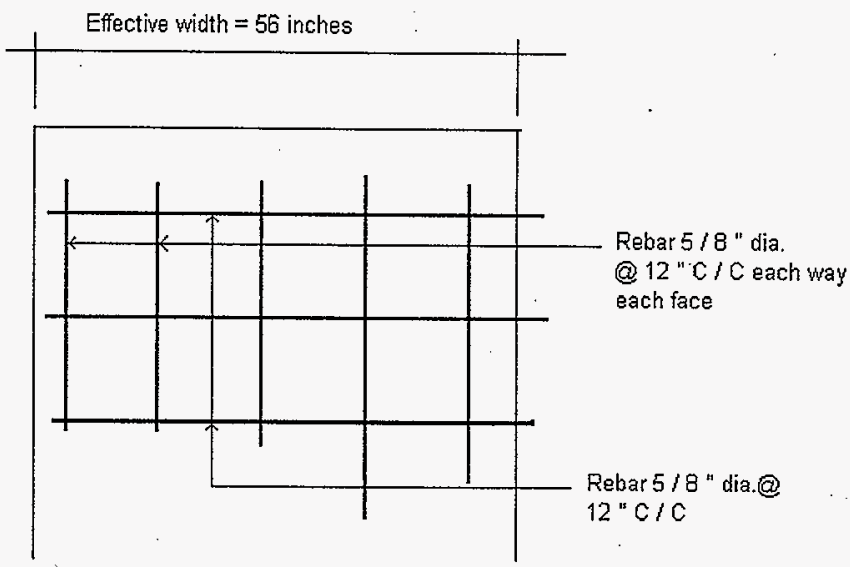

TYPICAL WALL. REINFORCEMENT 


\section{Fluor Daniel Northwest}

Title: Mixer and Transfer pump drop analysis, Project W-211

Designed by: $S$. Kanillal $S_{2}$

Date glials7

Checked by N.D. Ha $/ \mathrm{h}=$ - Page C-12

Date $7 / 16 / 97$

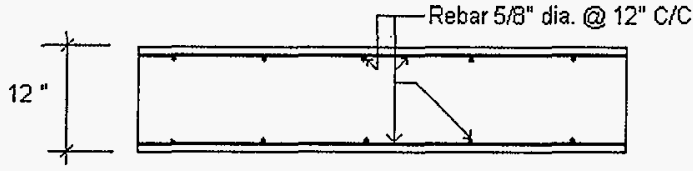

Cross Section of Effective Wall

Width

Weight of concrete $=p c$ in lb/cubic feet

$$
\propto:=150
$$

Compressive strength of Concrete $=4000 \mathrm{psi}$ ffc $:=4000$

Moduius of Elasticity $=\mathrm{Ec}$

$$
\text { Ec : }=\rho c^{1.5} \cdot 33 \cdot \sqrt{f f c} \quad \text { Ec }=3.834 \cdot 10^{6}
$$

$\mathrm{Ec}_{\mathrm{c}}=3.834 \times \mathrm{e} 6 \mathrm{psi}$

Refer section 9.2.6 $\mathrm{ACl} 318 / 318 \mathrm{R}-83$, the impact load is considered as a live load, hence a load factor of 1.7 will be multiplied to get the required strength of concrete.

Dead weight of concrete at mid height of the wall = Dwall

$$
\text { bw }:=\frac{56}{12} \cdot \mathrm{ft} \quad \mathrm{tw}:=1 \cdot \mathrm{ft} \quad \mathrm{hw}:=\frac{82.75}{12} \cdot \mathrm{ft}
$$

Dwall $:=b w \cdot t w \cdot \frac{h w}{2} \cdot a \cdot \frac{\mathrm{lb}}{\mathrm{ft}^{3}}$

Dwall $=2.414 \cdot 10^{3} \cdot 1 \mathrm{~b}$

Ultimate Design Load and Moment $=(\mathrm{Pu}$ and Mu $)$

Pimp : $=70000 \cdot 1 \mathrm{lb}$

$$
\text { Pu }:=1.4 \cdot \text { Dwall }+ \text { 1.7.Pimp }
$$

$\mathrm{Mu}:=1.7 \cdot$ Pimp.ewall

$$
\begin{aligned}
& \mathrm{Pu}=1.224 \cdot 10^{5} \cdot \mathrm{lb} \\
& \mathrm{Mu}=3.719 \cdot 10^{5} \cdot \mathrm{lb} \cdot \mathrm{in}
\end{aligned}
$$


Title: Mixer and Transfer pump drop analysis, Project $W$-211

\begin{tabular}{|c|c|}
\hline $\mathrm{db}$ & Checked by N.D. Ha Mhe Page C-14 \\
\hline $9 \sqrt{16}$ & 97 \\
\hline
\end{tabular}

$$
\begin{aligned}
& \text { Esteel }:=29 \cdot 10^{6} \cdot \frac{\mathrm{lb}}{\mathrm{in}^{2}} \\
& \text { gy }:=\frac{\text { fys }}{\text { Esteel }} \quad \text { y }=0.002 \\
& \mathrm{~d} 1:=12 \cdot \mathrm{in}-\left(1.5+\frac{5}{8}+\frac{5}{16}\right) \cdot \text { in } \quad \mathrm{d} 1=9.563 \cdot \text { in } \\
& \mathrm{d} 2:=1.5 \cdot \mathrm{in}+\frac{5}{8} \cdot \mathrm{in}+\frac{5}{16} \cdot \mathrm{in} \quad \mathrm{d} 2=2.438 \cdot \text { in }
\end{aligned}
$$

Calculate max. axial load capacity of this column :

$\$$ Pnmax : $=8 \cdot 7 \cdot(.85 \cdot \mathrm{fc} \cdot(\mathrm{Ag}-$ Astotal $)+$ fys $\cdot$ Astotal $)$

$\$$ Pmax $=1.371 \cdot 10^{6} \cdot 1 \mathrm{~b} \quad$ Or Max axial load $=1371 \mathrm{kips}$.

Compute axial load and moment capacity for balanced failure

$$
c:=\frac{.003}{.003-(-1 \cdot z y)} \cdot d 1 \quad c=5.659 \cdot \text { in } \quad \begin{aligned}
& \text { where } c=\text { depth of the neutral axis } \\
& \text { from the compression face. }
\end{aligned}
$$$$
\approx 2:=\frac{c-d 2}{c} .003 \quad \varepsilon s 2=0.002 \quad \begin{aligned}
& \text { where } \varepsilon s 1 \text { and } \varepsilon s 2 \text { are the strain in the steel in } \\
& \text { comp and tension face. }
\end{aligned}
$$

$$
\varepsilon 1:=-.00207
$$




\section{Fluor Daniel Northwest}

Title: Mixer and Transfer pump drop analysis, Project W-211

Designed by: S. Kanillal \&8

Date $9 \mid 16,67$
Checked by N. D. Ha Whe Page C-15

Date

$$
\begin{aligned}
& \text { fs2 := } \approx 2 \cdot \text { Esteel } \quad \mathrm{fs} 2=4.953 \cdot 10^{4} \cdot \frac{\mathrm{lb}}{\mathrm{in}^{2}} \quad \begin{array}{l}
\text { Stress in steel } \mathrm{fs} 2=49.53 \mathrm{kips} .<60 \mathrm{ksi} \text { this } \\
\text { is the stress in the compressive layer of reinf. }
\end{array} \\
& \text { Stress in tension layer is } 60 \mathrm{ksi} \\
& \beta 1:=1.05-.05 \cdot \frac{4000 \cdot \mathrm{psi}}{1000 \cdot \mathrm{psi}} \quad \beta 1=0.85 \quad a=\text { depth of the equivalent rectangular stress block } \\
& \mathrm{a}:=\beta 1 \cdot \mathrm{c} \quad \mathrm{a}=4.811 \cdot \text { in }
\end{aligned}
$$

Compute forces in the concrete and steel

$$
\begin{aligned}
& C_{c}:=0.85 \cdot f c \cdot a \cdot b \text { wall } \quad C c=9.159 \cdot 10^{5} \cdot \mathrm{lb} \quad \text { Where } \mathrm{Cc}=\text { force in the concrete } \\
& =915.9 \text { kips. }
\end{aligned}
$$

Fs1 : fys.As1 Fsi $=8.686 \cdot 10^{4} \cdot \mathrm{lb} \quad$ Force on reinf. layer on the comporessive side Fs2 $:=\left(\right.$ ss $\left.2-.85 \cdot 4000 \cdot \frac{\mathrm{lb}}{\mathrm{in}^{2}}\right) \cdot$ As $2 \quad$ Fs $2=6.68 \cdot 10^{4} \cdot \mathrm{lb}$

$$
\begin{array}{lrr}
\text { Pn } 1:=\mathrm{Cc}-\mathrm{Fs} 1+\mathrm{Fs} 2 & \mathrm{Pn} 1=8.959 \cdot 10^{5} \cdot \mathrm{lb} & \phi P n 1=\text { Design axial force } \\
\phi:=.7 & =627 \mathrm{kips} \\
\phi \cdot \mathrm{Pn} 1=6.271 \cdot 10^{5} \cdot \mathrm{lb} & \phi P n 1=627 \mathrm{kips}
\end{array}
$$

Compute $\mathrm{Mn}$

$$
\begin{aligned}
& \mathrm{Mn}:=\mathrm{Cc} \cdot\left(\frac{\text { twall }}{2}-\frac{a}{2}\right)+\mathrm{Fs} 1 \cdot\left(\frac{\text { twall }}{2}-\mathrm{d} 1\right)+\mathrm{Fs} 2 \cdot\left(\frac{\text { twall }}{2}-\mathrm{d} 2\right) \\
& \mathrm{Mn}=3.84 \cdot 10^{6} \cdot \mathrm{lb} \cdot \mathrm{in} \\
& \phi \mathrm{Mn}=2.688 \cdot 10^{6} \cdot \mathrm{lb} \cdot \mathrm{in} \quad \phi \mathrm{Mn}=2688 \text { kip.in or } 224 \mathrm{ft} \cdot \mathrm{kip}
\end{aligned}
$$


Title : Mixer and Transfer pump drop analysis, Project W-211

Designed by: S. Kanilial S $8 x$ Checked by N.D. Ha for Page C-16

Date alkelar

Date

$9 / 16 / 97$

Compute axial load and moment for the strain is -3 times the balanced strain
$c:=\frac{.003}{.003-(-3 \cdot \varepsilon y)} \cdot d 1$
$c=3.116 \cdot$ in
where $\mathrm{c}=$ depth of the neutral axis
from the compression face.

$$
\begin{aligned}
& \approx s 2:=\frac{c-d 2}{c} \cdot 003 \\
& \approx 1:=-3 \cdot 0.00207 \\
& \approx 1=-0.006
\end{aligned}
$$$$
\varepsilon 2=6.531 \cdot 10^{-4}
$$
where $\varepsilon s 1$ and $\varepsilon s 2$ are the strain in the steel in comp and tension face.

Stress in the reinforcing layers

$$
\begin{aligned}
& \text { fss } 2:=\varepsilon 2 \cdot \text { Esteel } \quad \text { fss } 2=1.894 \cdot 10^{4} \cdot \frac{\mathrm{lb}}{\mathrm{in}^{2}} \\
& \text { fss } 1:=60000 \cdot \frac{\mathrm{lb}}{\mathrm{in}^{2}} \\
& \text { a1 }:=\beta 1 \cdot \mathrm{c} \quad \text { al }=2.648 \cdot \text { in }
\end{aligned}
$$

Compute forces in concrete and steel

$$
\mathrm{Ccl}:=.85 \cdot \mathrm{fc} \cdot \mathrm{al} \cdot \mathrm{bwall} \quad \mathrm{Ccl}=5.043 \cdot 10^{5} \cdot \mathrm{lb}
$$

\section{Steel}

Fss1 :=fys·Asl

$$
\text { Fss } 1=8.686 \cdot 10^{4} \cdot 1 \mathrm{~b}
$$

Since a1 is greater than $d 2$

$$
F s s 2:=(f s s 2-0.85 \cdot f c) \cdot A s 2 \quad F s s 2=2.25 \cdot 10^{4} \cdot l b
$$

\section{Compute Pn2}

$$
\begin{array}{ll}
\operatorname{Pn} 2:=\mathrm{Ccl}-\text { Fss } 1+\text { Fss } 2 & \operatorname{Pn} 2=4.399 \cdot 10^{5} \cdot \mathrm{lb} \\
\phi \cdot \operatorname{Pn} 2=3.079 \cdot 10^{5} \cdot \mathrm{lb} & \text { Axial load allowable }=308 \mathrm{kips}
\end{array}
$$


Fluor Daniel Northwest

HNF-SD-TWR-CN-002

Rev. 0

Appendix - C

Title: Mixer and Transfer pump drop analysis, Project W-211

Designed by: $S$. Kaniilal 803

Date

9.16157

Checked by N.D. Ha /Cle Page C-17

Date $9 / 16 / 24$

Compute Mn

$\mathrm{Mnl}:=\left[\mathrm{Ccl} \cdot\left(\frac{\text { twall }}{2}-\frac{\mathrm{al}}{2}\right)-\mathrm{Fss} 1 \cdot\left(\frac{\text { twall }}{2}-\mathrm{d} 1\right)\right]+\mathrm{Fss} 2 \cdot\left(\frac{\text { twall }}{2}-\mathrm{d} 2\right)$

$\mathrm{MnI}=2.747 \cdot 10^{6} \cdot \mathrm{lb} \cdot \mathrm{in} \quad \$ \cdot \mathrm{Mnl}=1.923 \cdot 10^{6} \cdot \mathrm{lb} \cdot$ in $\quad$ Moment $=1923 \mathrm{kip}$.in

OR 160.25 ft kips .

Compute axial load and moment for the strain is -5 times the balanced strain
$c:=\frac{.003}{.003-(-5 \cdot g)} \cdot d l$
$\mathrm{c}=2.15 \cdot \mathrm{in}$
where $c=$ depth of the neutra! axis from the compression face.

$$
\begin{aligned}
& \text { es } 2:=\frac{c-d 2}{c} \cdot 003 \\
& \text { ss }:=-5 \cdot 0.00207 \\
& \approx s 1=-0.01
\end{aligned}
$$
$\approx 2=-4.016 \cdot 10^{-4}$
where $\varepsilon s 1$ and $\varepsilon s 2$ are the strain in the steel in comp and tension face.

Stress in the reinforcing layers

$$
\begin{aligned}
& \text { fss } 2:=\approx 2 \cdot \text { Esteel } \quad \text { fss } 2=-1.165 \cdot 10^{4} \cdot \frac{1 \mathrm{~b}}{\mathrm{in}^{2}} \\
& \text { fss } 1:=60000 \cdot \frac{\mathrm{lb}}{\mathrm{in}^{2}} \\
& \mathrm{al}:=\beta 1 \cdot \mathrm{c} \cdot \quad \text { al }=1.827 \cdot \mathrm{in}
\end{aligned}
$$

Compute forces in concrete and steel

$$
\text { Cel }:=.85 \cdot f \mathrm{c} \cdot \mathrm{al} \cdot \mathrm{bwall} \quad \mathrm{CcI}=3.479 \cdot 10^{5} \cdot \mathrm{lb}
$$

Steel

Fss $1:=$ fys. As $1 \quad$ Fss $1=8.686 \cdot 10^{4} \cdot \mathrm{lb}$ 


\section{Fluor Daniel Northwest}

HNF-SD-TWR-CN-002

Rev. 0 Appendix $-\mathrm{C}$

Title: Mixer and Transfer pump drop analysis, Project W-211

Designed by:S. Kanillal 86 Checked by N.D. Ha fac Page $\mathrm{C}-18$

Date olicis7 Date $9116 / 97$

Since a1 is less than d2

Fss2 :=(fss2).As2 $\quad$ Fss2 $=-1.686 \cdot 10^{4} \cdot \mathrm{lb}$

Compute $\mathrm{Pn} 2$

$\mathrm{Pn} 2:=\mathrm{Ccl}-\mathrm{Fssl}+\mathrm{Fss} 2 \quad \mathrm{Pn} 2=2.442 \cdot 10^{5} \cdot 1 \mathrm{~b}$

$\phi \cdot P_{2} 2=1.709 \cdot 10^{5} \cdot \mathrm{lb} \quad$ Axial load allowable $=171 \mathrm{kips}$

Compute $\mathrm{Mn}$

$\mathrm{Mn} 1:=\left[\mathrm{Ccl} \cdot\left(\frac{\text { twall }}{2}-\frac{\mathrm{a} 1}{2}\right)-\mathrm{Fssl} \cdot\left(\frac{\text { twall }}{2}-\mathrm{d} 1\right)\right]+$ Fss2 $\left(\frac{\text { twall }}{2}-\mathrm{d} 2\right)$

$\mathrm{Mnl}=2.019 \cdot 10^{6} \cdot \mathrm{lb} \cdot$ in $\quad \phi \cdot \mathrm{Mnl}=1.413 \cdot 10^{6} \cdot \mathrm{lb} \cdot$ in $\quad$ Moment $=1413 \mathrm{kip}$.in

OR 117.75 ft kips

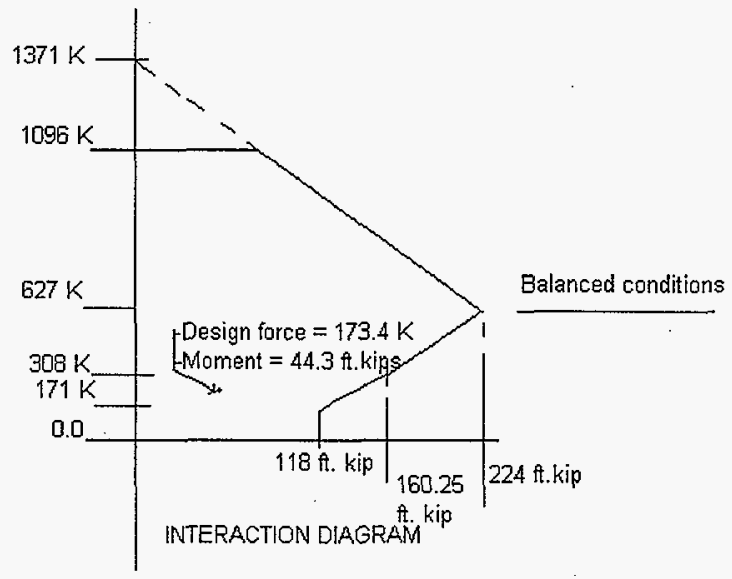


Fluor Daniel Northwest

HNF-SD-TWR-CN-002

Rev. 0

Appendix - C

Title : Mixer and Transfer pump drop analysis, Project $W-211$

$\frac{\text { Designed by:S. Kaniilal } 86}{\text { Date }} \frac{\text { Checked by N.D. Ha } / 16 \text { he Page C-19 }}{9 / 16 / 97}$

Check west wall with reaction forces $28.7 \mathrm{kips} / \mathrm{ft}$. loading.

Load for 56 inches length $=28.7 \times 56 / 12=133.93 \mathrm{kip}$

With 1.7 ACl load factor the impact load is $1.7 \times 133.93=227.7 \mathrm{kip}$

Factored moment Muw $=227.7 \times 3.125$ (eccentricity) $=711.5$ kip.in or 59.29 ft.kip

Factotred dead load : $1.4 \times \mathrm{DW}$

Puwest := 1.4.Dwall $+227700 \cdot 1 \mathrm{~b}$

Puwest $=2.311 \cdot 10^{5} \cdot \mathrm{lb} \quad$ Total factored axial load $=230 \mathrm{kip}$

$\frac{\text { Puwest }}{\phi}=3.301 \cdot 10^{5} \cdot \mathrm{lb} \quad$ Design load axial $=328.7 \mathrm{kip}$

Muw :=711500-1b-in

$\frac{\text { Muw }}{d}=1.016 \cdot 10^{6} \cdot \mathrm{lb} \cdot \mathrm{in} \quad$ Design Moment $=1016 \mathrm{kip}$.in or $85 \mathrm{kip} . \mathrm{ft}$

Both the axial load and the design moment fall inside the Interaction diagram, Hence O. K .

Lateral pressure Moment on wall : This wall will behave as a plate fixed on three sides. the depth of soil around the side of this pit is $3.5 \mathrm{ft}$. approx. Hence the moment due to lateral pressure is small. Comparing with the interaction diagram, the wall is capable of taking the lateral pressure moment and the moment created by the eccentric loading together with the axial loads. Hence the wall is considered adequate for the impact loadings. 
Fluor Daniel Northwest

HNF-SD-TWR-CN-002

Title : Mixer and Transfer pump drop analysis, Project W-211

Rev. 0 Appendix - C

Designed by: S. Kanilial Se Checked by N.D. Ha

dese Date

Page C-20

Date 0 (16/5)

$9 / 16 / 97$

O2D PUMP PIT DESIGN EVALUATION FOR IMPACT LOADS:

241-AP TANK FARM.

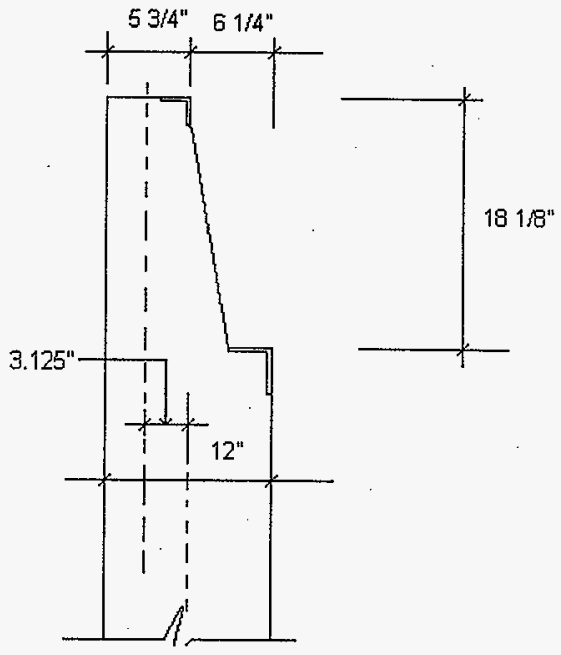


Title: Mixer and Transfer pump drop analysis, Project W-211

Rev. 0 Appendix - C

$\frac{\text { Designed by:S. Kaniilal Ske }}{\text { Date } a \mid i(15)} \frac{\text { Checked by N.D. Ha fers Page C-21 }}{\text { Date }}$

The concrete wall will behave as a column of effective width $b w=$ width of bearing $+4 X$ thickness of wall.

$$
b w:=8 \cdot \text { in }+4 \cdot 12 \cdot \text { in } \quad b w=56 \cdot \text { in }
$$

Find reinforcement ratio $\mathrm{pr}=\mathrm{As} / \mathrm{bd}$

$$
\begin{aligned}
& \text { bconc }:=12 \cdot \text { in } \quad \text { dconc }:=12 \cdot \text { in }-\left(2+\frac{3}{4}+\frac{3}{2}\right) \cdot \text { in } \quad \begin{array}{l}
\text { dconc }=8.875 \cdot \text { in } \\
d=\text { effective depth of conc. section } \\
\text { Clear cover 2" }(H-2-76462 \text { sh. } 1)
\end{array} \\
& \begin{array}{ll}
\text { Ast }:=0.88 \cdot \text { in }^{2} \quad \begin{array}{l}
\text { Ast }=\text { Area of steel per } 12 \text { " width } \\
2-\# 6 \text { bars }
\end{array} & \text { pconc }=0.008
\end{array}
\end{aligned}
$$

As the eccenctricity $3.125^{\prime \prime}$ exceeds wall thickness $/ 6$, the empirical design method is not applicable.

a) Check wall slenderness : $k l u / r$ where $k=$ effective length factor. For wall laterally restrained and fixed at the base as in this case $k=1$

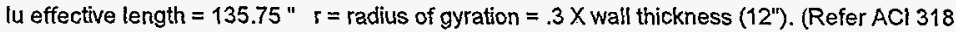
section 10.11.3)

$$
\begin{aligned}
& \mathrm{k}:=1 \quad \mathrm{lu}:=135.75 \cdot \mathrm{in} \quad \mathrm{r}:=.3 \cdot 12 \cdot \mathrm{in} \\
& \frac{\mathrm{k} \cdot \mathrm{lu}}{\mathrm{r}}=37.708 \quad \\
& \quad
\end{aligned}
$$

Interaction Diagram for the wall column section :

$$
\begin{aligned}
& \text { fo }:=4000 \cdot \frac{\mathrm{lb}}{\mathrm{in}^{2}} \quad \text { fys }:=60000 \cdot \frac{\mathrm{lb}}{\mathrm{in}^{2}} \quad \begin{array}{l}
\text { Where } \quad f y t=\text { steel yeild strength. } \\
\text { for }
\end{array} \\
& \text { bwall }:=56 \text { in twall }:=12 \text { in } \quad \text { bwall }=\text { width of section } \\
& \text { twall }=\text { thickness of section } \\
& \text { Asl }:=4.67 \cdot .44 \cdot \mathrm{in}^{2} \quad \text { Asl }=2.055 \cdot \mathrm{in}^{2} \\
& \text { As2 }:=2.055 \cdot \text { in }^{2} \quad \text { Astotal }:=\text { Asl }+ \text { As2 } \quad \text { Astotal }=4.11 \cdot \mathrm{in}^{2} \\
& \mathrm{Ag}:=\text { bwall } \cdot \text { twall } \quad \mathrm{Ag}=672 \cdot \mathrm{in}^{2}
\end{aligned}
$$




\section{Fluor Daniel Northwest}

HNF-SD-TWR-CN-002

Title: Mixer and Transfer pump drop analysis, Project W-211

Rev. 0 Appendix - C

Designed by: S. Kaniilal \&6

Date
Checked by N.D. Ha pee

Date Page $\mathrm{C}-22$

$$
\begin{aligned}
& \text { pconc : }=\frac{\text { Astotal }}{\mathrm{Ag}} \quad \text { pconc }=0.006 \\
& \text { As1 and As2 are the steel area on each face } \\
& \varepsilon y=\text { the yeild strain on steel } \\
& \text { Esteel }:=29 \cdot 10^{6} \cdot \frac{\mathrm{lb}}{\mathrm{in}^{2}} \\
& \text { हy }:=\frac{\text { fys }}{\text { Esteel }} \quad \text { gy }=0.002 \\
& \mathrm{~d} l:=12 \cdot \mathrm{in}-\left(2+\frac{3}{4}+\frac{3}{8}\right) \cdot \mathrm{in} \quad \mathrm{dl}=8.875 \cdot \text { in } \\
& \text { d2 }:=2 \cdot \text { in }+\frac{3}{4} \cdot \text { in }+\frac{3}{8} \cdot \text { in } \quad \text { d2 }=3.125 \cdot \text { in }
\end{aligned}
$$$$
\text { of the wall }
$$

Calculate max. axial load capacity of this column:

$\$$ Pnmax $:=, 8 \cdot 7 \cdot(.85 \cdot f \mathrm{f} \cdot($ Ag - Astotal $)+\mathrm{fys} \cdot$ Astotal $)$

Pnmax $=1.41 \cdot 10^{6} \cdot \mathrm{lb} \quad$ Or Max axial load $=1410 \mathrm{kips}$.

Compute axial load and moment capacily for balanced failure

$$
\begin{aligned}
& \mathrm{c}:=\frac{.003}{.003-(-1 \cdot \mathrm{gy})} \cdot \mathrm{dl} \quad \mathrm{c}=5.253 \cdot \mathrm{in} \quad \begin{array}{l}
\text { where } \mathrm{c}=\text { depth of the neutral axis } \\
\text { from the compression face. }
\end{array} \\
& \mathrm{s} 2:=\frac{c-\mathrm{d} 2}{\mathrm{c}} \cdot .003 \quad \mathrm{~s} 2=0.001 \quad \begin{array}{l}
\text { where } \varepsilon 1 \text { and } \mathrm{ss} 2 \text { are the strain in the steel in } \\
\text { comp and tension face. }
\end{array}
\end{aligned}
$$

s1 $:=-.00207$ 
Title : Mixer and Transfer pump drop analysis, Project W-211

Rev. 0 Appendix - C

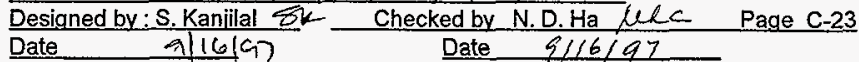

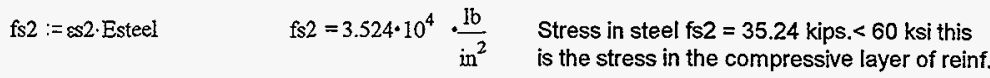

Stress in tension layer is $60 \mathrm{ksi}$

$\beta 1:=1.05-.05 \cdot \frac{4000 \cdot \mathrm{psi}}{1000 \cdot \mathrm{psi}} \quad \beta 1=0.85 \quad \mathrm{a}=$ depth of the equivalent rectangular stress block
$a:=\beta 1 \cdot c$
$\mathrm{a}=4.465+\mathrm{in}$

Compute forces in the concrete and steel

$$
\begin{aligned}
& \mathrm{Cc}:=0.85 \cdot \mathrm{fc} \cdot \mathrm{a} \cdot \mathrm{bwall} \quad \mathrm{Cc}=8.501 \cdot 10^{5} \cdot \mathrm{lb} \quad \text { Where } \mathrm{Cc}=\text { force in the concrete } \\
& =850.1 \text { kips. }
\end{aligned}
$$

Fs $1:=$ fys $\cdot$ As $1 \quad$ Fs $1=1.233 \cdot 10^{5} \cdot \mathrm{lb} \quad$ Force on reinf. layer on the comporessive side

Fs2 $:\left(\mathrm{fs} 2-.85 \cdot 4000 \cdot \frac{\mathrm{lb}}{\mathrm{in}^{2}}\right) \cdot$ As $2 \quad$ Fs2 $=6.543 \cdot 10^{4} \cdot \mathrm{lb}$

$$
\begin{aligned}
& P_{n l}:=\mathrm{Cc}-\mathrm{Fs} 1+\mathrm{Fs} 2 \quad \mathrm{Pnl}=7.922 \cdot 10^{5} \cdot \mathrm{lb} \quad \mathrm{Pn} 1=\text { Nominal axial force } \\
& \text { Q }:=.7
\end{aligned}
$$

$\oint \cdot \operatorname{Pnl}=5.546 \cdot 10^{5} \cdot \mathrm{lb} \quad \phi \mathrm{Pn} 1=554.6 \mathrm{kips}$

\section{Compute Mn}

$\mathrm{Mn}:=\mathrm{Cc} \cdot\left(\frac{\text { twall }}{2}-\frac{\mathrm{a}}{2}\right)+\mathrm{Fs} 1 \cdot-\frac{\mathrm{d} 1-\mathrm{d} 2}{2}+\mathrm{Fs} 2 \cdot \frac{\mathrm{d} 1-\mathrm{d} 2}{2}$

$\mathrm{Mn}=3.036 \cdot 10^{6} \cdot 1 \mathrm{~b} \cdot$ in

Pn $=2.126 \cdot 10^{6} \cdot \mathrm{lb} \cdot$ in $\quad \phi M n=2126$ kip.in or 175 ft.kip 
Title : Mixer and Transfer pump drop analysis. Project W-211

Rev. 0 Appendix - C

Designed by:S. Kanillal Sk Checked by N.D. Ha Whe Page C-24 Date S|l6!a7

Date $9116 / 47$

Compute axial load and moment for the strain is -3 times the balanced strain

$$
c:=\frac{.003}{.003-(-3 \cdot \approx y)} \cdot d 1 \quad c=2.892 \cdot \text { in } \quad \begin{aligned}
& \text { where } c=\text { depth of the neutral axis } \\
& \text { from the compression face. }
\end{aligned}
$$

$$
\begin{aligned}
& \approx 2:=\frac{c-d 2}{c} \cdot 003 \quad \& 2=-2.419 \cdot 10^{-4} \quad \begin{array}{l}
\text { where } \varepsilon s 1 \text { and } \varepsilon s 2 \text { are the strain in the steel in } \\
\text { comp and tension face. }
\end{array} \\
& \approx s 1:=-3 \cdot 0.00207 \\
& \approx s 1=-0.006
\end{aligned}
$$

Stress in the reinforcing layers

$$
\begin{aligned}
& \text { fss }: \text { : } 2 s 2 \text { - Esteel } \quad \text { fss } 2=-7.014 \cdot 10^{3} \cdot \frac{\mathrm{lb}}{\mathrm{in}^{2}} \\
& \text { fss }:=60000 \cdot \frac{\mathrm{lb}}{\mathrm{in}^{2}} \\
& \text { al }:=\beta 1 \cdot \mathrm{c} \quad \text { al }=2.458 \cdot \text { in }
\end{aligned}
$$

Compute forces in concrete and steel

$$
\begin{aligned}
& \mathrm{Cc} 1:=.85 \cdot \mathrm{fc} \cdot \mathrm{a} 1 \cdot \mathrm{bwall} \quad \mathrm{Cc} 1=4.68 \cdot 10^{5} \cdot \mathrm{Ib} \\
& \text { Steel }
\end{aligned}
$$

$$
\text { Fss }:=\text { fys-Asl } \quad \text { FssI }=1.233 \cdot 10^{5} \cdot \mathrm{lb}
$$

Since a1 is greater than $d 2$

$$
\begin{aligned}
& \text { Fss } 2:=f s s 2 \cdot A s 2 \quad F s s 2=-1.441 \cdot 10^{4} \cdot 1 b \\
& \text { Compute Pn2 }
\end{aligned}
$$

$$
\begin{array}{ll}
\operatorname{Pn} 2:=\text { Cc1 }- \text { Fss1 +Fss2 } & \operatorname{Pn} 2=3.303 \cdot 10^{5} \cdot \mathrm{lb} \\
\text { Q.Pn2 }=2.312 \cdot 10^{5} \cdot \mathrm{lb} & \text { Axial load allowable }=210.6 \mathrm{kips}
\end{array}
$$




\section{Fluor Daniel Northwest $\quad$ HNF-SD-TWR-CN-002}

Title: Mixer and Transfer pump drop analysis, Project W-211

Rev. 0 Appendix - C

Designed by: S. Kanilial fok Checked by N.D. Ha thRs

Date olicis?

Date

$q 116 / a 7$

\section{Compute Mn}

$$
\begin{aligned}
& M n 1:=C c 1 \cdot\left(\frac{t w a l l}{2}-\frac{a 1}{2}\right)-F s s 1 \cdot\left(\frac{d 1-d 2}{2}\right)+F s s 2 \cdot\left(\frac{d 1-d 2}{2}\right) \\
& \mathrm{Mn} 1=1.837 \cdot 10^{6} \cdot \mathrm{lb} \cdot \mathrm{in} \\
& \phi \cdot \mathrm{Mnil}=1.286 \cdot 10^{6} \cdot \mathrm{lb} \cdot \mathrm{in} \\
& \text { Moment }=1286 \text { kip.in } \\
& \text { OR } 107 \mathrm{ft} \text { kips }
\end{aligned}
$$

Compute axial load and moment for the strain is -5 times the balanced strain

$$
\begin{aligned}
& c:=\frac{.003}{.003-(-5 \cdot z y)} \cdot d 1 \quad c=1.995 \cdot \text { in } \quad \begin{array}{l}
\text { where } c=\text { depth of the neutral axis } \\
\text { from the compression face. }
\end{array} \\
& \varepsilon s 2:=\frac{c-d 2}{c} \cdot 003 \quad \quad \& 2=-0.002 \quad \begin{array}{l}
\text { where } \varepsilon s 1 \text { and } \varepsilon s 2 \text { are the strain in the steel in } \\
\text { comp and tension face. }
\end{array} \\
& \approx 1:=-5 \cdot 0.00207 \\
& \varepsilon 1=-0.01
\end{aligned}
$$

Stress in the reinforcing layers

$$
\begin{aligned}
& \text { fss } 2:=\approx 2 \cdot \text { Esteel } \quad \text { fss } 2=-4.927 \cdot 10^{4} \cdot \frac{1 \mathrm{~b}}{\mathrm{in}^{2}} \\
& \text { fss } 1:=60000 \cdot \frac{\mathrm{lb}}{\mathrm{in}^{2}} \quad \text { al }=1.696 \cdot \text { in }
\end{aligned}
$$

Compute forces in concrete and steel

$$
\mathrm{Cc1}:=.85 \cdot \mathrm{fc} \cdot \mathrm{al} \cdot \mathrm{bwall} \quad \mathrm{Ccl}=3.229 \cdot 10^{5} \cdot \mathrm{lb}
$$

Steel

Fss1 $:=$ fys As1 $\quad$ Fss $1=1.233 \cdot 10^{5} \cdot \mathrm{lb}$ 
Fluor Daniel Northwest

Title: Mixer and Transfer pump drop analysis, Project W-211

Rev. 0 Appendix - C

Designed by: S. Kanillal \& $\&_{2}$ Checked by N.D.Ha

Date Q116197

Date

Page C-26

$9 / 16 / 47$

Since $a 1$ is less than $d 2$
Fss2 : $=($ fss2 $) \cdot A s 2$
$F s s 2=-1.012 \cdot 10^{5} \cdot \mathrm{lb}$

Compute $\mathrm{Pn} 2$

$\operatorname{Pn} 2:=\mathrm{Cc} 1-\mathrm{Fss} 1+$ Fss $2 \quad \mathrm{Pn} 2=9.836 \cdot 10^{4} \cdot \mathrm{lb}$

$\oint \cdot \operatorname{Pn} 2=6.885 \cdot 10^{4} \cdot \mathrm{lb} \quad$ Axial load allowable $=68.85 \mathrm{kips}$

Compute $\mathrm{Mn}$

$\operatorname{Mnl}:=\left[\operatorname{Cc1} \cdot\left(\frac{\text { twall }}{2}-\frac{\mathrm{a} 1}{2}\right)-\right.$ Fss $\left.1 \cdot\left(\frac{\text { twall }}{2}-\mathrm{d} 1\right)\right]+$ Fss $2 \cdot\left(\frac{\text { twall }}{2}-\mathrm{d} 2\right)$

$\mathrm{Mnl}=1.727 \cdot 10^{6} \cdot \mathrm{lb} \cdot$ in $\quad \phi \cdot \mathrm{Mnl}=1.209 \cdot 10^{6} \cdot \mathrm{lb} \cdot$ in $\quad$ Moment $=1209$ kip.in

OR $100.75 \mathrm{ft}$ kips

Compute axial load and moment for the strain is -5.5 times the balanced strain

$c:=\frac{.003}{.003-(-5.5 \cdot g y)} \cdot d 1 \quad c=1.852 \cdot$ in $\quad \begin{aligned} & \text { where } c=\text { depth of the neutral axis } \\ & \text { from the compression face. }\end{aligned}$ $\varepsilon s 2:=\frac{c-d 2}{c} \cdot .003 \quad \& 2=-0.002 \quad \begin{aligned} & \text { where } \varepsilon s 1 \text { and } \varepsilon s 2 \text { are the strain in the steel in } \\ & \text { comp and tension face. }\end{aligned}$

\&s $:=-5 \cdot 0.00207$

$\varepsilon s 1=-0.01$

Stress in the reinforcing layers

fss $2:=\approx 2 \cdot$ Esteel $\quad$ fss $2=-5.983 \cdot 10^{4} \cdot \frac{\mathrm{lb}}{\mathrm{in}^{2}}$

fss $1:=60000 \cdot \frac{\mathrm{lb}}{\mathrm{in}^{2}}$

al $:=\beta 1 \cdot \mathrm{c} \quad$ al $=1.574 \cdot$ in 


\section{Fluor Daniel Northwest}

HNF-SD-TWR-CN-002

Title : Mixer and Transfer pump drop analysis, Project W-211

Rev. 0 Appendix - C

Designed by:S. Kaniilal \&

Date Q116/47

Checked by N.D. Ha $\mu$ he

Page C-27

Date $\quad 9 / 16 / 97$

\section{Compute forces in concrete and steel}

Cc1 :a.85. fc al bwall

$$
\mathrm{Ccl}=2.997 \cdot 10^{5} \cdot \mathrm{lb}
$$

Steel

Fss $1:=$ fys $\cdot$ As $1 \quad$ Fss $1=1.233 \cdot 10^{5} \cdot \mathrm{lb}$

Since a1 is less than $\mathrm{d} 2$

$$
\text { Fss } 2:=(\mathrm{fss} 2) \cdot \mathrm{As} 2 \quad \text { Fss } 2=-1.23 \cdot 10^{5} \cdot \mathrm{lb}
$$

\section{Compute Pn2}

$$
\begin{array}{ll}
\mathrm{Pn} 2:=\mathrm{Cc} 1-F s s 1+F s s 2 & \mathrm{Pn} 2=5.343 \cdot 10^{4} \cdot \mathrm{lb} \\
\phi \cdot \operatorname{Pn} 2=3.74 \cdot 10^{4} \cdot \mathrm{lb} & \text { Axial load allowable }=37.4 \mathrm{kips}
\end{array}
$$

Compute $\mathrm{Mn}$

$\operatorname{Mn1}:=\left[\mathrm{Cc1} \cdot\left(\frac{\text { twall }}{2}-\frac{\mathrm{al}}{2}\right)-\mathrm{Fss}_{\mathrm{s} I} \cdot\left(\frac{\text { twall }}{2}-\mathrm{d} 1\right)\right]+\mathrm{Fss} 2 \cdot\left(\frac{\text { twall }}{2}-\mathrm{d} 2\right)$

$$
\begin{array}{ll}
\mathrm{Mn} 1=1.563 \cdot 10^{6} \cdot \mathrm{lb} \cdot \mathrm{in} \quad \mathrm{Mnl}=1.094 \cdot 10^{6} \cdot \mathrm{lb} \cdot \mathrm{in} \quad \begin{array}{l}
\text { Moment }=1094 \text { kip.in } \\
\text { OR } 91.2 \mathrm{tt} \text { kips }
\end{array}
\end{array}
$$


Fluor Daniel Northwest

HNF-SD-TWR-CN-002

Title: Mixer and Transfer pump drop anaivsis. Proiect W-211

Rev. 0 Appendix -C

Designed by: S. Kanjilal O2. Checked by N. D. Ha

Date air6/5?

Date

a) $16 / 9)$

Page $\mathrm{C}-28$

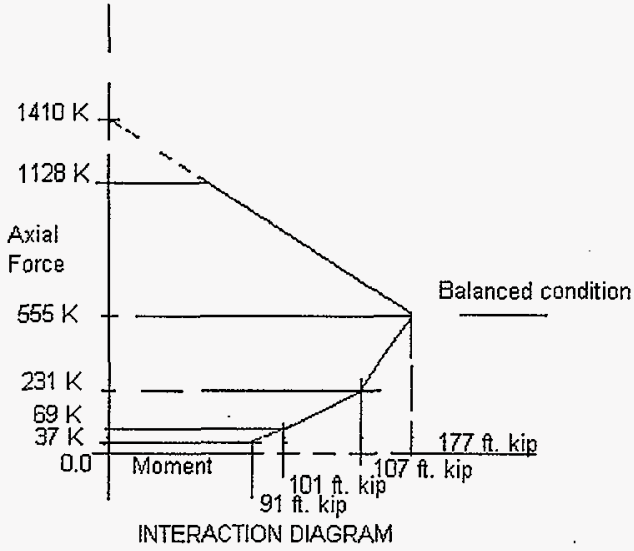

Maximum reaction at the north wall support $=47.66 \mathrm{kips}$.

$\mathrm{Pu}=$ Ultimate reaction load on wall $=1.7 \times 47.66$

$\mathrm{Pn}=\mathrm{Pu} / \phi=1.7 \times 47.66 / .7=116$ kips.

Moment due to eccentricity $=47.66 \times 3.125=148.94 \mathrm{kip}$. in. $=12.42 \mathrm{ft}$. kip

$\mathrm{Mu}=1.7 \times 12.42=21.11 \mathrm{ft}$. Kip

$\mathrm{Mn}=21.11 / \phi=21.11 / .7=30.16 \mathrm{ft}$. kip

From the interaction diagram the wall can carry $[101+\{(107-101) /(231-69) \times(116-69)\}]$

$=102.7 \mathrm{ft}$. kip $>12.42 \mathrm{ft}$. kip GOOD

The self weight will increase the compression and will increase the moment capacity hence ignored. (conservative)

There will be some moment magnification due to KLr $>34$, since the allowable moment is much greater than the actual moment, the magnified moment should be well within the allowable. No further calculation is necessary.

The wall is good to carry the impact loading. 


\section{Fluor Daniel Northwest}

Tifle : Mixer and Transfer pump drop analysis, Project W-211

HNF-SD-TWR-CN-002

Rev. 0 Appendix - C

Designed by: S. Kanjilal 8 K

Date Checked by N.D.Ha ter. Page C-29

Date 10/1197

\section{Check sliding of the tank pit due to impact forces.}

Approximate weight of the pump pit concrete assuming 12 " constant thickness of the wall : Center line length $=2 \times\left(12^{\prime}-0^{\prime \prime}+7^{\prime}-0^{\prime \prime}\right)=38^{\prime}-0^{\prime \prime}$

Weight @150 lb / cft of concrete $=1 \times 38^{\prime \prime}-0^{\prime \prime} \times 1^{\prime}-0^{\prime \prime} \times\left\{679^{\prime}-6^{\prime \prime}-668^{\prime}-5.25^{\prime \prime}=11^{\prime}-3 / 4^{\prime \prime}\right\}$ (average) $\times 150 \mathrm{lb} / \mathrm{cft}$ $=63056 \mathrm{lbs}$.

Weight of base of the tank

$$
\begin{aligned}
& =1 \times 13^{\prime}-0^{\prime \prime} \times 8^{\prime}-0^{\prime \prime} \times 1.5^{\prime} \text { (average thickness) } \times 150 \mathrm{lb} / \mathrm{cft} \\
& =23400 \mathrm{lbs} .
\end{aligned}
$$

Total weight of the concrete pit

$$
=63056 \mathrm{lb} .+23400 \mathrm{lb} .=86456 \mathrm{lbs} .
$$

Add $10 \%$ for fixtures and platforms etc. $=8646 \mathrm{lbs}$.

Total gross weight $=86456+8646=95102 \mathrm{lbs}$

Sum of the reactions from pump drop: 143500 (west wall) +71900 (North wall) $=215400 \mathrm{lbf}$. The ANSYS model is symmetrical about East / West. Hence, the total reaction forces are doubled to take care of the whole pit. The Impact force on the East wall is small because of its location away from the impact location and ignored.

The total reaction forces $=2 \times 215400=430800 \mathrm{lbs}$. The reaction on the east wall is not significant and ignored.

Total downward force from impact and dead weight of pit $=430800+95102=525902 \mathrm{lbs}$.

Assuming a $3 \mathrm{ft}$. drop (based on scaling of the drawing dimensions) in $7 \mathrm{ft}$. width of the tank, the slope of the tank $=\tan -13 / 7=23.2$ degrees.

The sliding force $=525902 \sin 23.2=207175 \mathrm{lb}$.

\section{Friction force against sliding}

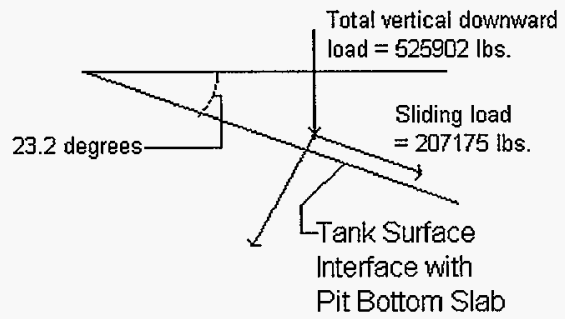


Title : Mixer and Transfer pump drop analysis, Project W-211

The Coefficient of Friction of new concrete against hardened concrete which is true in this case, $=1$ (Refer Reinforced Concrete Design, Third Edition, by Wang and Salmon Section 5.16)

Hence the total ressisting force $=1 \times 525902 \mathrm{lbs}$.

Margin of safety against sliding $=1-207175 / 525902=.606$

GOOD.

\section{Check Tank Dome :}

Refer WHC-SD-WM-DA-111, Rev. 1, Page 7, maximum allowable concentrated load on the tank dome placed anywhere on the dome is $600 \mathrm{kips}$.

Considering the pump pit as a concentrated load on the dome (which is very conservative), the total vertical reaction from the impact loading and the concrete dead weight is $525902 \mathrm{lb}$ or 526 kips. which is less than the capacity of the tank.

The tank dome is safe

o. K. 